\title{
Computersimulatie en wiskundige modellen in het medisch onderwijs : het RL- computersimulatiesysteem
}

Citation for published version (APA):

Min, F. B. M. (1982). Computersimulatie en wiskundige modellen in het medisch onderwijs : het $R L-$ computersimulatiesysteem. [Doctoral Thesis, Maastricht University]. Rijksuniversiteit Limburg. https://doi.org/10.26481/dis.19821217fm

Document status and date:

Published: 01/01/1982

DOI:

10.26481/dis.19821217fm

Document Version:

Publisher's PDF, also known as Version of record

Please check the document version of this publication:

- A submitted manuscript is the version of the article upon submission and before peer-review. There can be important differences between the submitted version and the official published version of record. People interested in the research are advised to contact the author for the final version of the publication, or visit the DOI to the publisher's website.

- The final author version and the galley proof are versions of the publication after peer review.

- The final published version features the final layout of the paper including the volume, issue and page numbers.

Link to publication

\footnotetext{
General rights rights.

- You may freely distribute the URL identifying the publication in the public portal. please follow below link for the End User Agreement:

www.umlib.nl/taverne-license

Take down policy

If you believe that this document breaches copyright please contact us at:

repository@maastrichtuniversity.nl

providing details and we will investigate your claim.
}

Copyright and moral rights for the publications made accessible in the public portal are retained by the authors and/or other copyright owners and it is a condition of accessing publications that users recognise and abide by the legal requirements associated with these

- Users may download and print one copy of any publication from the public portal for the purpose of private study or research.

- You may not further distribute the material or use it for any profit-making activity or commercial gain

If the publication is distributed under the terms of Article $25 \mathrm{fa}$ of the Dutch Copyright Act, indicated by the "Taverne" license above, 
computersimulatie en wiskundige modellen

in het

medisch onderwijs;

het RL-computersimulatiesysteen 
Promotor: prof.dr. H.A.J. Struyker-Bowdier

co-promotor: prof.dr. W.H.F.W. Wi inen

Referenten: prof́.dr. F.I.M. Bonke

dr. A. Dirkzwager

prof.dr. J.M. van Rossm

Dit proefschrift werd bewerkt in de capaciteitsgroep farmacologie, van de Rijksuniversiteit Limburg te Maastricht 
Computersimulatie en wiskundige modellen

in het

medisch onderwijs;

het RL-computersimulatiesysteem

\section{PROEFSCHRIFI}

ter verkrijging van de graad van doctor in de geneeskunde aan de Rijksuniversiteit Limburg te Maastricht op gezag van rector magnificus Prof.Dr. H.C. Henker, volgens besluit van het College wan Dekanen in het openbaar te verdedigen op vrijdag 17 december, 's middags om vier uur precies, in de aula wan de universiteit

door

Fredericus Bernardus Maria Min, geboren te Bergen $\mathbb{N H}$ 
De latste jaten vindt er een stormachtige ontwikkeling plats op het gebied van toepassingen van de computer in het onderwijs. Er is nog duidelijk sprake van een fase van experimenteren met het type computer. de geschikte programeertal, bruikbare onderwijsprograma's e.d. Systematische beschrijuingen van deze experimenten zíjn nog schars. In dit proefschrift will ik de mogelijkheden em beperkingen van de twepassingen van computersimulaties aan, vooral wiskundige, model len in een medisch curriculum bespreken. Bij een dergelijk onderwerp komt een breed scala aspecten aan de orde, variërend van de keuze van een computerconfiguratie tot aan oplossingsmethoden voor complexe stelsels wiskundige vergelijkingen en de methode vartwiskundige modelvorming in de geneeskunde tot onderwijskundige voorwarden voor optimal gebruik van simulatieprograma's.

Met ieder van deze aspecten is een aantal wetenschappelijke disciplines gemoeid. Ik heb getracht de voor het onderwerp van dit proefschrift noodzakelijke uitgangspunten op het gebled van ieder van deze disciplines te bespreken. Het accent is hierbij eerder komen te 1 iggen op het gebruik van wiskundige modellen en computersimulaties in de geneeskunde en het medisch onderwijs, dan op een onderwijskundige bespreking van computer ondersteunde onderwijsmethoden. Onderwijskundige taetsing van een nieuw leermiddel dient gebaseerd te zijn op een zorgvuldig samengesteld toetsingsinstrumentarium, warbij bovendien van te voren vast moet staan welk onderwijseffect wordt nagestreefd met het nieuwe leermiddel. Het doel van de hier beschreven studie was veeleer de ontwikkeling van een computersysteem t.b.v. het uitvoeren van sirmulaties aan wiskundige modelien van processen die wan betekents zijn voor het medisch onderwijs. De beschrijving wan zo"n studle impliceert ook voor de lezers, afkomstig uit verschillende wetenschappelijke disciplines. het leggen van prioriteiten in de aandacht. Ik heb in ieder geval die delen van de studie warvan beschrijuing in de tekst niet zonder meer nodig is voor een goed begrip, in een antal appendices opgenomen. Daarnast $z a l$ de medisch geschoolde docent of student grote delien van hoofdstuk. 2 over methoden van wiskundige modelvorming en computersimulaties, alsmede de gedetaflleerde modelbeschrijuingen in hoofdstukken 4, 5 en 7 kunnen overslaan. Voor degenen met een meer uitgesproken interesse in informatica en wiskundige modelvorming daarentegen is kennisneming van de ultvoerige voorbeelden van medische probleemstellingen in hoofdstukken 3 tot en met 9 niet altijd noodzakelijk. 
1 WHOUD

1. Inledding

1.1 Computer Ondersteund Onderwifs, Computer Assisted Instruction en Computers imulatie

1.2 Simulatie en modelvorming

- Algemeen

- Simulatie in de medische wetenschappen

- Wskundige modellen in de medische wetenschappen

1.3 Kenmerken medisch onderwijs en curriculum van de Rijksuriversteit Limburg

1.4 Dit proefschrift

2. Methodische aspecten t.a. v. wiskundige modelvorming en computersinulaties

2.1. Wiskundige modelvorming

- Modelworming en sinulatiemerhoden

- Regelsys temen

- Nummerleke oplossingsmethade

- Algebralsche loops

2.2 Overwegingen bij de keuze van hardware, software en courseware t.b.w. simulatiesysteem.

- Hogere programmeertaal, simulatietaal of auteurstaal

- Terminalsysteem

- Centraal systeem versus decentraal systeem

- Machine-student aanpassingen en responstijden

- Werkomgeving

2.3 Beschrijuing van het RL-computersimulat lesysteem (RLCS-systeem)

- Hardware RL-computersimulatiesysteem

- Sof cware RL-computersimulatiesysteem

- Functle van afzonderlijke programma's in het systeem

* programina START

* programma DOOR

* programma VERAND

* programa INSPEC

- Functle van afzonderlijke files in het systeem

* Datafile RL. DAT

* Startwardenfile RESTAR. DAT

* (Patient) casusfiles casus1.DAT t/m CASUS6.DAT.

* Resultatenfile RESULT.TXT 
3. Computersimulatieprogramia AORTA

- Onderwijsdoel

- Het windketelmodel.

- Opbouw van het model.

- Resultaten

- Discussie

- Referenties

- Literatuurlijst

4. Computersimulat ieprograma CARD Lo

- Onderwijsdoel

- Model van het cardiovasculaire systeem

- Opbouw van het model

- Resultaten

* Hartinfarct

* Hypertensie

- Discussie

- Referenties

- Literatuurlijst

5. Computersimulatieprogramma FLUids

- Onderwijsdoe1

- Model van de water- en electrollethushouding

- Opbouw van het model.

- Resultaten

* Dorsten

* Dorsten, zweten en zoutverlies

* Waterinname

* Glucosetolerantietest

* Verhoogde $\mathrm{CO}_{2}$ inname

* Zuur-base evenwicht verstoringen

- Discussie

- Referenties

- Literaturlijst

6. Computersimulat leprogramma FARMA

- Onderwijsdoel

- Het open twee compartimenten model.

- Resultaten

- Discussie

- Referenties

- Literatuur 11 jst

7. Computersimulatieprograma MACDOPE

- Onderwijsdoel.

- Het fysiologische 8 compartimenten model

- Opbouw van het model

- Resultaten

* Acetylsalícy lzuur

* Ampicilline 
- Discussle

- Referenties

- Literaturifist

8. Computers ind lat ieprogramma ANAMNESE

- Onderwijsdoel

- Algemene methode die aan het programa ten grondslag 1 igt

- Programabeschrijuing

- Resultaten

* Rheumathoide arthritus

* Hyperventilatiesyndroom "oesophagusspasmen en psychosociale problematiek

- Discussie

- Referentieg

- Literaturitifist

9. Computers Imulatieprogramma ENZYM

- Onderin Ijgdoed

- Model var een enzymreactie

- Resultaten

- Discussie

- Referenties

- Literatuurlifst

10. Evaluatie en conclusies:

10. I Evaluatiegegevens.

- Onderwijsblokken en gebruik van programma"s

- Computersimulat leprograma's

- Computersimulatleprogramma's per jaargroep

- Computersimulatieprogramma's per groep studenten

- Waardering (enige preliminaire gegevens)

- Bloktoets (enige preliminaire gegevens)

- Voortgangstoets (enige preliminaire gegevens)

10.2 Conclusies

11. Sumary and conclusive remarks 


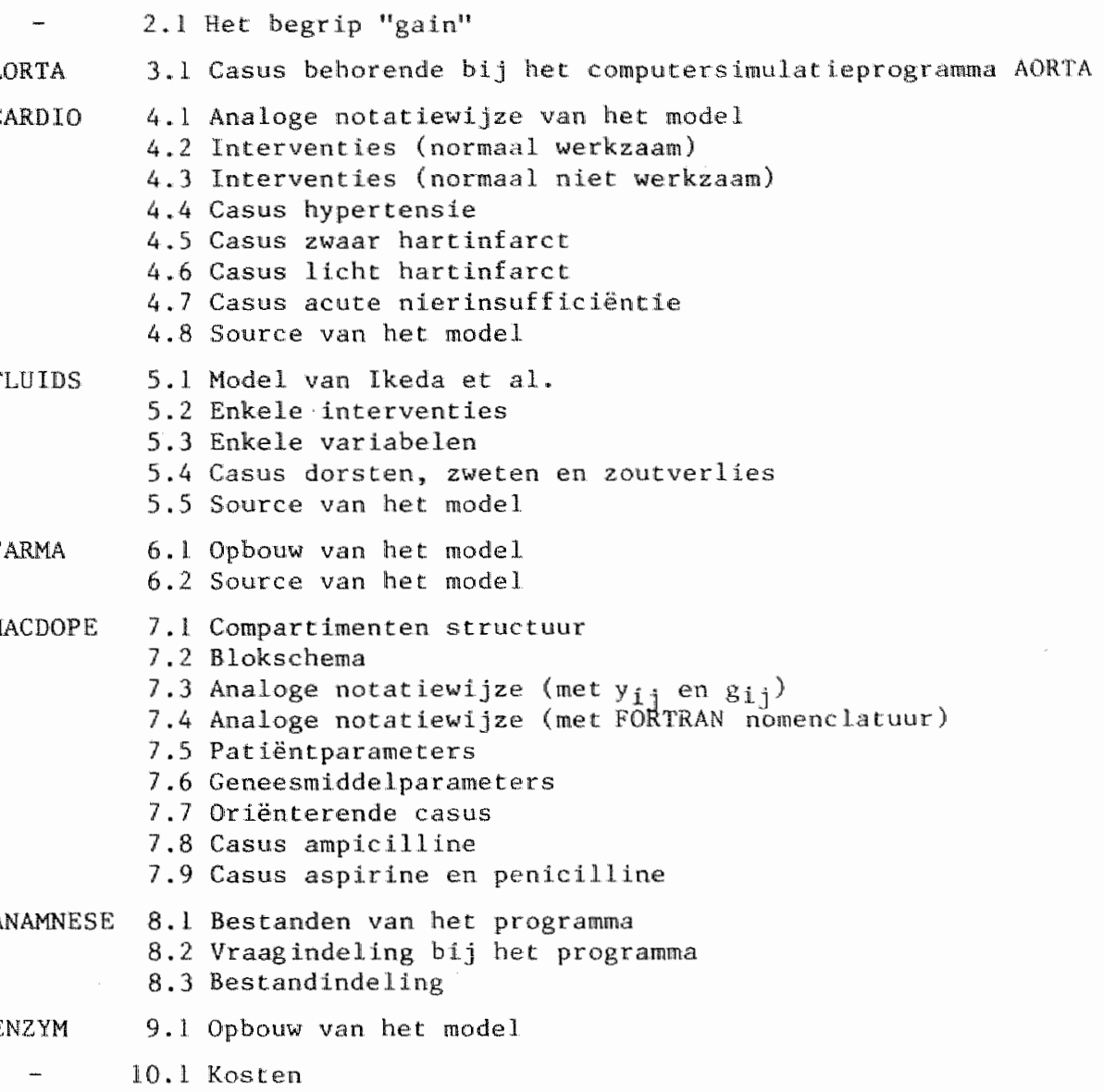


HOOFDSTUR $\mathbb{1}$

Inleiding

Het onderwerp van deze studie is het gebruik van computersimulatias in het kader van probleem georiënteerd medisch onderwijs. In dit eerste hoofdstuk zullen de 3 belangrijkste invalshoeken voor deze studie worden ingeleld. Het gat hierbij om:

1. Het gebruik van de computer in het medisch onderwijs In paragraaf 1.1 zat het begrip Computer ondersteund onderwis (coo) en met name "Computer Assisted Instrution (CAI) kort worden besproken. Dit zal in het bijaonder worden toegespitst op het gebruik van computersimilaties in het nedisoh onderwijo.

2. Wiskundige mode Luoming en sumatatie

In paragraaf 1.2 zat een aantal witgangspunten voor wiskundige modelvoming en (computer) simulatie worden besproken. Meer in het bijzonder zal het gebruik van wiskundige modetien en sumulaties daamee in de nedische wetenschappen worden ingeleid.

3. Probzem geomienteond onderutis

Een belangrijk uitgangsput van deze studie was de bijzondere ondinwitsongeving warin de stutie werd uitgevoend. Aan de medische fortiteit van de Rijkswiversiteit Limburg werd gewerkt met problem georiënteend (of takgericht onderwijs. Dease vorm van onderwijs a al in prmagraaf 1.3 worden ingeleit.

Deze diverse invalshoeken tonen dat deze studie zich zal moeten bewegen op een aantal terreinen: de informatica, de toegepaste onderwijskunde, wiskundige modelvorming en medische wetenschappen. In figuur 1 . I is getracht deze verschillende disciplines en hun samenhang aan te geven om aan te tonen dat computersimulatie gebaseerd op wiskundige modellen als leermiddel in het medisch onderwijs een multidisciplinair karakter heeft. 


\section{Computertechnok}

1. Informetica

2. Hardware

3. Sottuare

4. Sinnut teprogramadur

5. Fryomonis
Wiskunde en Model worming

1. Modelvoming

2. Comceptue nodel en

3. Wiskndige modellen

4. Nomer leke oplossingumathoks

5. Simulatie methodes

conputersimulatieprogramm" Gobaserd op whkunige nodelien als leveriddel in het problem georienteerd medisch onderw js

Medische wetenschappen

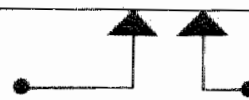

\section{Onderw i jskunde}

1. Vormen van onderw $\mathrm{j}$.

2. Probleem georienteerd ondorwi is

3. Toegepaste onderwijskude

4. CAI (algemeen)

5. Simulatie (algemeen)

Figutur I. L: Disciplines watrop computersimulaties in het medisch onderwigh ân gebaseerd. Per discipline wordt in dit proefschrift op de belangrifkste aspecter ingegan. 
1. 1. Computer Onderstennd Onderwijs, Computer Assisted Inscruction en Computersimulatie.

In dit proefschrift worden computersimulatieprograma's zoals die in hoofdstuk 3 tot en met 9 worden beschreven gerekend tot wat in het Nederlands taalgebied wordt genoend Computer Ondersteund Onderwijs (COO) en meer in het bijzonder tot wat in de internationale literatur met Computer Assisted Instruction (CAI) wordt angeduid. Ondat de hier besproken computersimulat leprogramma's worden gerekend tot Computer Assisted Instruction en niet tot andere vormen van Computer ondersteutad onderwijs $z$ an in het verwolg met name de term Computer Assisted Instruction worden gebrulkt Computer Assisted Instruction is een vorm van geind widualiseerd onderwijs warbij een directe interaktie tussen de student en een computer programma mogelijk is. Het leermateriaal en de onderwijsstrategie zijn over het algemeen in thet CAI-programma vastgelegd. De interaktie gebeurt met een terminal, bestaande uit een beeldscherm en een toetsenbord. De oorspronkelijke vormen van CAI stammen uit geprogrammeerde instructies m.b.v. de computer (GI). Deze onderwijsvorm is in sterke mate gebaseerd op principes uit de behavioristische psychologie, zoals "feedback" en "reinforcement". Inmiddels is CAI uitgegroeid tot een middel van onderwijs dat op een veelheid van onderwijskundige principes is gebaseerd (Fox en Rushby, 1979; Gastkenper et a1.,1979; Lew is en Harris, 1980; Tagg,1980). In deze studie zal vooral worden ingegaan op het gebruik van computersimulaties. Dit is echter slechts één van de mogelijkheden wan computer ondersteund onderwijs. De belangrifkste vormen van onderwijs in dit verband zoals de Nederlandse Verenigung voor onderwijs en Computers (VoC) in har publicatios geeft, en zoals za ook staan gedefinueerd in de Encyclopedia of Education (Weldenhamer et al.,1976; Gastkemper et al.,1977 en 1979) zijn:

- "drill and practioe". Dit is aefenen in cogntieve vaardigheid, warbij steeds eenvoudige en eventueel steeds verschillende opgaven gepresenteerd worden, gevolgd door een bevestiging of verbetering van antwoorden. Dit wordt herhald totdat aan een bepadd kriteritum is volidaan.

- "tutomal". Hierbij wordt zorguldig gestructureerde informat is geven en worden antwoorden van de student geinterpreteerd. Nlichil spelen vormen van terugkoppeling ("feedback') een essentido rol.

- "dralogue". Dit is een verdergaande worm van een tutorlal onderwi javorm. De studiesequentie is niet van te voren gestructureerd. De 
student 1 in het ideale geval vrij om te handelen zoals hij wil. Een programma in deze vorm eist vaak een hoog ontwikkeld databestand en "natural language" procedures.

- "ingutry". Deze vorm wordt vak in een adem met "dialogue" vermeld en ls gertcht op een systeem van informatie vragen.

- "probtem solving". Hierbij $1 \mathrm{~s}$ de student aldoende bezig een probleem op te lossen. De student kan het programa gebruiken voor het witvoeren van de verelste operaties.

- "simulation". Het uitwoeren wan een proces dat sterk door de student kan worden beinwloed en warbij wiskundige modellen worden gebruikt om bij Interventles aan het model de gevolgen die dat heeft voor varlabelen te bepalen.

- "modelling". Bij deze worm stelt de student een model op en/of modiflceert dit.

- "gaming". Deze vorm wordt vajk in een adem met "simulation" vermeld, mar heeft meestal een spelelement of een element wan competitie in zich.

De wormen van computer ondersteund onderwifs waarmee tot nu toe de meeste ervaring is opgedaan zijn de "tutorial" en "drill and practice" vormen. Dit is begrijpelijk gezlen de beperkingen die bestaan in het ontwerpen van andere vormen van computer ondersteund onderwijs. In deze studie zal worden gepoogd het gebruik van computersimulatie als onderwijsvorm nader uiteen te zetten. De laatste jaren wordt in de internationale Lteratur in toenemende mate aandacht geschonken aan deze vorm van computer ondersteund onderwijs (Pearson, 1977; Mckenzle, 1978; Garbut et al.,1979; Morel,1979; B1och, 1980; Bramer, 1980). Voural in de exacte wetenschappen, warin modelvorming en wiskundige notatiewlyzen al Langer voorkomen, wordt inmiddels veel gebruik gemaakt van computersimulatieprograma $\mathrm{s}$ in het onderwifs. In de medische wetenschappen, het specifieke donein van deze studie, is nog vrijwel geen exvaring met computersimulaties in het onderwijs. Het enige goed gedocumenteerde project in dit verbsnd is dat van de MAC programa's, afkomstig van de Medical School van McMaster University te Canada Deze programma"s komen in hoofdstuk 2 verder aan bod. Voor een ultwoerlger bespreking van diverse vormen van computer ondersteund onderwijs wordt hier verder verwezen naar de literatuur. Algemene literatuur over computers in het onderwijs kan worden gewonden In de "Index to Computer Based Learning" (Index,1978), de proceedings van de "World Conference on Computer Education" (WCCE) van de 
"International Federation for Information Processing" (IF"LP) (Lacarne en Lewis, 1975; Lewis en Tagg,1979; Tagg,1980; Tagg en Lew1s,1981), de abstracts en proceedings van de "Computer Assisted Learning" symposia (CAL 77, 1977; CAL 79, 1979 en CAL 81, 1981) en het "International Yearbook of Educational and Instruction Technology" (1978) dat in Engeland is uitgegeven door het National Development Programe in Computer Assisted Learning (NDPCAL) (Hooper, 1978). Enkele belangrijke boeken over CAI zijn internationaal: "Computers and the Learning process in higher Education" van Rockart en Morton (1975), "An Introduction to Educational Computing" van Rushby (1979) en nationaal: "Leren en Onderwijzen met de Computer" van Camstra (1980) en "Computergestuurd (hoger) onderwijs" van Moonen en Gastkemper (in druk).

In de internationale literatur wordt inmldels veel gepubliceerd over technische ontwikkelingen en ower de CAI-programa"s ("courseware'). In mindere mate wordt er gepubliceerd over onderwijskundige ervaringen. De ontwikkeling van CAI is met het goedkoper worden van computersystemen de laatste 5 jaar in een stroomversnelling terecht gekomen. Het heeft geresulteerd in gespeclaliseerde tijdschriften, zoals "Journal of Computer Based Instruction"; "Programmed Learning Educational Technology" en met name "Computers and Education", die nu veel publiceren wat daarvoor versnipperd in een reeks van andersoortige tijdschriften moest gebeuren zoals in de geneeskunde bijw. "Computer Programs in Blomedicine", "Computers in Biomedical Research", "Computers and Medicine", "Computers in Biology and MedicIne" en in "Simulation". 


\section{2 stmulatie en modelvorming}

Im deze paragrad zal nader worden ingegan op de overwegingen die een rol hebben gespeeld bij de keuze van simulaties als vorm van computer andersteund onderwiys t.b.w. het medisch curriculum.

Computersimulat le gebaseerd op wiskundige model hen is met de introducthe van de analoge computer, mat in het bijzonder van de digitale computer, in bljna alle wetenschappen en in de technitek een niet meer weg te denken methode van wetenschap geworder. De internationale ilteratur toont een reeks van toepassingen van computersimulaties op een breed terretin van vakgebleden, zoals op het gebled van management (Driscoll,1981), taalwetenschappen (Ahi,1975; Artew, 1979), geologie (Neale,1979), techalek (Bekey,1977; Bronson, 1978; Demald et a1.,1981), scheepvaart, 1uchtvaart, rulmtevaart, chemie (Cassano,1977; Beech,1978), biologie (Gann et a1, 1973; Ibera11,1975; Plant, 1979; Verveen, 1980) en biomedische wetenschappem (Guyton et al.,1972; Coleman,1978; Xates,1978; StruykerBoudler en Min, 1979; Bloch et al.,1980). Een goed leesbaar Nederlandstalig overzicht wordt gegeven in het cursusboek bij de recente TELEAC cursus "wiskundige modellen" (Teleac, 1981).

Het simuleren van een verschijnsel is het nabootsen van dat verschijnse $\mathbb{1}$ met behulp van een model. Dit model heef een structur en kan in bepaalde gevallen een stelsel wiskundige vergelijkingen zijn (Min en Struyker Boudier, 1979). Meer algemeen gesproken zijn modelien ontwerpen wen de werkelijkheid daamee trachten te simuleren, essentiële bestanddelen van het menselijk denken en communiceren. Fen model is een representatie van de werkelijkheid, met als doel de werkelijkheid beter te begrijpen of woorspellingen te kunnen doen over het toekonstig "gedrag" van de werkelijkheid. Indien gebrutk wordt gemakkt van wiskundige vergelifkingen om de relaties tussen de elementen van de werkelifkheid te beschrijven, is ex sprake van een wiskundig model. In de geschiedents van de naturwecenschappen spelen wiskundige modellen a heel lang ten belangrijke rol. Zo experimenteerde Maxwell ruim 100 Jaar geleden met magneten en koperen gelelders en formleerde een antal van zijn bevindingen in we varm van een stelsel wiskundige vergelifkingen. Hij gem bruikte deze vergelijkingen als model door een aantal parameters die oorspronkelijk constant geacht werden te varièren. Op die wijze kon hil voorspellingen doen over het fysisch gedrag van de verschijnselen die hil bestudeerde. Vervolgens toetste hif deze voorspellingen met 
behulp van experimenten aan de werkelijkheld. Dit voortdurend iteratief proces van experiment - wiskundige modelvorming * nieuwe experimenten vormt thans een belangrijk fundament wan het wetenschappelijk denken in een aantal vakgebleden.

\section{Simulatie in de medische wetenschappen}

De oudste wijze van modelvorming in de geneeskunde is de constructie van een conceptueel mode1 (Partridge,1971). De Franse fllosoof Descartes bijwoorbeeld, ontwlkkelde in zijn werk een model van een mens, waarin hij ervan uitging dat het menselijk lichaam als een machine functioneert.

Een tweede wijze van modelvorming in de medische wetenschappen is het gebruik van empirische modellen. Voorbeelden hiervan aijn de fantomen: anatomische modellen. Dergelijke anatomische modellen spelen een belangrijke rol in het onderwijs aan (medische) studenten. Een tweede voorbeeld van een empirisch model is een kunststof arm, met een "levensechte" ader en slagader warmee studenten oefenen in het afnemen van "bloed", vóórdat ze in èchte armen van patiënten prikken. De derde wijze van gebruik van modellen in de medische wetenschappen zijn de proefdiermodellen. Met name de latste jaren warin de medische wetenschappen een explosieve ontwikkeling in de experimentele benadering hebben doorgemaakt, zifn proefdiemodellen een belangrijke rol gaan spelen. Zo zijn er nu rattenstammen met een erfelijk bepaalde vorm van hoge bloeddruk, die worden gebruikt als model voor de bypertensie bi.j menser.

Al deze voorbeelden tonen het belang van modellen in de medische wetenschappen. Ook wljzen ze op een diversitelt aan soorten modellen. De keuze van het soort model wordt bepald door het doel dat wordt gedlend: een fantoom heeft een uitstekende functie in het anatomle-onderwijs, maar draagt niet bij tot een beter inzicht in thet verloop van fundanentele chemische processen in de cel.

\section{Wiskundige modellem in de medlsche wetenschap}

In de medische wetenschappen is een toenemende interesse in dis dynanische eigenschappen van (onderdelen wan) het menselljk lichaam. De anderzokker neemt geen genoegen meer met een kwalltatleve beschrijuing varn die onderdelen van het organisme. De medische onderzoeker probeert het ge- 
drag vam het organlome in kwantitat leve termen te beschrijven. Deze ontwlkkellng heeft gevolgen gehad voor de wijze van modelvorming in de medische wetenschappen. Kwantitatieve analyse noopt tot het gebrulk van wiskundige modellen. De onderzoeker presenteert zijn hypothese in dergelijke gevallen, in de vorm van een wiskundig model in plats van een conceptueel of empirisch mode1. De wiskunde is bij ultstek een taal warin kwantltatleve hypotheses heel precies kunnen worden geformuleerd. Ben hypothese die wiskundig wordt geformuleerd, kan zeer rigoreus worden getoetst en (keer op keer) worden vervangen door een betere hypothese. De kwalltelt van een wiskundig model als hypothese, is niet zozeer afhankelijk van de taal warin de hypothese is geformuleerd, als wel van de experimentele data die ten grondslag $11 \mathrm{ggen}$ a an de geformuleerde relaties. Een tweede belangrijk voordeel wan het gebruik wan wiskundige modellen in de geneeskunde is de mogelijkheid tot het uitvoeren van "hypothetische experimenten". In de blomedische wetenschappen is het accent in toenemende mate komen te IIggen op het experimenteel terrein. Als laatste voordeel $\mathrm{kan}$ worden aangehald de al eerder genoemde moge11 jkheld, met behulp van computermodellen thet normaal en abnormal gedrag van complexe biologische systemen te kunnen nabootsen. Soms $z 1 j n$ er ook morele of economische bezwaren tegen het ultwoeren van experimenten an het werkelijk systeem. Als we bijvoorbeeld willen nagaan wat het effect is wan het plotseling afnemen van twee liter bloed ut het menselijk vaatstelsel, zullen we voor zo'n experiment géén vrijwilligers kunnen krijgen. Het computermodel laat deze manipulatie echter keer op keer zonder bezwaren toe.

De hier genoemde voordelen voor het gebrulk van computersirulaties aan wskundige modellen t.b.v. het onderzoek in de medische wetenschappen, kunnen ook worden toegepast op het gebrulk in het onderwijs.

In de literatur is door een aantal auteurs gewezen op de specifieke voordelen van het ultvoeren van simulaties aan computermodellen in het medisch onderwljs:

a. De tijdschaal kan worden veranderd. Perloden van weken en dagen kunnen tot redelijke proporties worden teruggebracht. Processen van enkele micraseconden kunnen tot seconden worden uitgerekt (Coleman, 1979a, b; Min en struyker Boudler, 1979).

b. Blj een model kan ledere vartabele worden bestudeerd, terwijl in een proefopstelling sommige variabelen moellijk of helemal niet gemeten kunnen worden. 
c. Computersimulatie kan op ieder moment dat de apparatuur beschikbaar is, en dat is meestal 24 uur per dag, plaatsvinden en zoveel tijd in beslag nemen als men wil. Daarbij komt voor onderwijs-georienteerde simulatiestudies nog dat men geen computerervaring nodig heeft. Experimentele meetopstellingen daarentegen $z i j n$ van vele factoren afhankelijk en men heeft over het algemeen veel ervaring met secundaire kwesties nodig."

d. Men kan snel en overzichtelijk essentiele begrippen en beperkingen van systemen laten zien door demonstratie van bijv. gedragingen m.b.t. niet-lineariteiten en verzadigingen c.q. limietbegrip.

e. Bij computersimulatie voert de student handelingen ult of neemt beslissingen in een nagebootste werkelifkheid, waarna hij wan het computerprogramma informatle ontvangt over de daardoor ontstane nieuwe toestand. Dit soort feedback is zeer $r j j k$ aan informatie. Naast deze speciffeke kenmerken kan nog op een algemeen aspect ontrent het gebrulk van wiskundige modellen en computerslmulaties in het (nedisch) onderwijs worden gewezen. Deze vorm van onderwils is niet zozeer gericht op het bevorderen van concrete kennis van bepalde problemen, maar poogt het logisch nadenken over systemen te stimuleren.

Als een student een parameter verandert wan een model, stelt hij zichzelf een probleem. Dit zelf doen en ontdekken wat er gebeurt is een zeer wezenlijk kenmerk van computersinulaties. In dit verband wordt verwezen naar een interessante ontwikkeling op het gebied van de toepassing van computers in onderwijs aan jonge kinderen, t.w. het LoGo-systeem.

LOGO is een programmertaal, warmee kinderen zelf problemen kunnen formuleren en trachten op te lossen door ontdekkend bezig te zijn. In zeer eenvoudige vorm wordt met LoGo gebruik gemakt van simulatienogelijkheden van de computer (cf. Dirkzwager et a1.1976; Papert, 1980; de Bouley en Howe; Belshuizen, Vac-voordracht, 1982 ; Pinxteren et al.,1982). In een antal blomedische basisvakken wordt de student vaak geconfronteerd met problemen die een goed inzicht in de dynamische samenhang tussen onderdelen van een systeem vergen. De uitleg in een handboek, zelfs indien gepresenteerd door een uitstekend docent, is niet altijd voldoende woor een goed begrlp omtrent deze samenhang. In dit opzicht kan een computersimulatie van een complex systeem wellicht een goede aanvulling zijn op andere vormen van onderwijs. Het experimenteren an een computermodel platst de student in de positie van een experinenteel. onderzoeker. Zodoende raakt de student vertrouwt met een aantal essutiële kenmerken van onderzoek: hij leert hypothesen op te stellen, dezk 
te toetsen en resultaten te interpteteren, nieuwe hypothesen op te stellen, etc. Julst dit lteratieve denkproces kan in belangrijke mate het Lnzlcht bevorderen. In de hoofdstukken 3 tot en met 9 wordt hier nader op lingegaan.

In dit proefschrift wordt ervan uitgegaan dat slechts op een beperkt aantal terrelnen van de medische wetenschappen wiskundige modelvorming en computersimulatie voor onderwijsdoeleinden van betekenis kan zijn. In dit verband $z i j$ in belangrijke factoren: er dient voldoende experimentele kennts te 21 in om tot hypothesevorming (en daarmee modelconstructie) te komen; het onderwerp van modelworming dient een dynamisch systeem of proces te zijn van een zekere minimale graad van complexiteit; het onderwerp dient van belang te zijn voor het onderwijs. Op die basis komt een aantal terretnen binnen de medische wetenschappen in aanmerking, zoals: regulatieprocessen in het cardlovasculair systeem, de ademhaling, de water- en electroliethuishouding, de nier, een aantal hormoonsystemen, alsmede de farmacokinetlek, de enzyminetiek, kinetische processen In het immunologisch systeem en de celmembraan. In de volgende hoofdstukken zal de aandacht m. $n$. Komen te liggen op het cardiovasculair systeem (de programma's AORTA en CARDIO) de ademhaling en water- en electroliethulshouding (FLUIDS), farmacokinetiek (FARMA en MACDOPE) en enzymkinetiek (ENZXM). 
1.3. Kenmerken medisch onderwijs en curriculum van de Rijksuniversiteit Limburg

Alvorens in te gaan op de doelstellingen van dit proefschrift is het nodig een paar opmerkingen te maken over het onderwijs aan de Rijksuniversiteit Limburg (RL).

Het onderwijs aan de RL verschilt van andere vormen van wetenschappelijk onderwijs in Nederland. Enkele belangrijke kenmerken zijn: probleem georiënteerd onderwljs, een systeem van voortgangsevaluatie en gerichtheld op zelfwerkzaamheld van de student.

Het universitair onderwijs wordt hierdoor niet alleen gezien als een proces van kennisoverdracht maar veeleer als een proces van kennisverwerving. Hierbij wordt aangenomen, dat de student naar de universiteit komt omdat hij lets wil leren. Hij kan bij dat leren gebruik maken van een veelheid aan middelen waaronder ook docenten. Uitgangspunt van de studie zijn concrete problemen, ontleend aan het prakt 1 jkveld. Door dit probleem georlënteerd onderwijssysteem ontdekt de student het belang van grote delen van wat in het traditionele systeem de basisvakken en de klinische vakken waren. De leerstof wordt dan ook niet gepresenteerd, zoals bijuoorbeeld bij een college, maar komt aan de orde in de onderwijsgroepen. Van de student wordt verwacht dat hij de vragen, die opkomen bij het behandelen van problemen in de onderwijsgroepen, kan beantwoorden door gebruik te maken van gegevens wit verschillende gebieden van de medische wetenschap, die hij zelf moet opsporen. op deze wijze ontstat een heel natuurlijk en vanzelfsprekend begrip voor de samenhang van de vakgebieden. De student werkt met een achttal medestudenten twee mal per week in een onderwijsgroep met problemen, zoals die geformuleerd zijn in een zogenaand blokboek van een 6 weken durende (blok)cursus, over een bepaald onderwerp, zoals pijn op de borst, moeheid, e.d. (zie onk figuur 1.2). De studenten stellen leerdoelen vast en gebruiken bij hun studie alle leermiddelen de $z$ lij nodig achten en die tot hun beschikking staan. De kennis die de student zoekt kan hij vinden in tijdschriften, boeken, videobanden of banddiaseries, bij zijn medestudenten of (desnoods) bij een vakinhoudsdeskundige. De student makt zelf zijn keuzen en draagt zelf de verantwoordelitkheld voor zijn eligen leerproces. Het onderwijs is erop gerlcht dat de studenten een groef doormaken in kemis, houding en vaardigheden die men door middel van een examen toetst. De Maastrichtse systeem is zo ontwikkeld dat een student niet tentamen gertcht zal 
Figuir 1.2. Indeling van de onderwjoblokken in de eerste 4 jaar var de medische studie an de RL in het studiejaar 1981/1982.

N.B.: Het "blok" evaluatie houdt een programm-evaluatie in en niet een studentevaluatie.
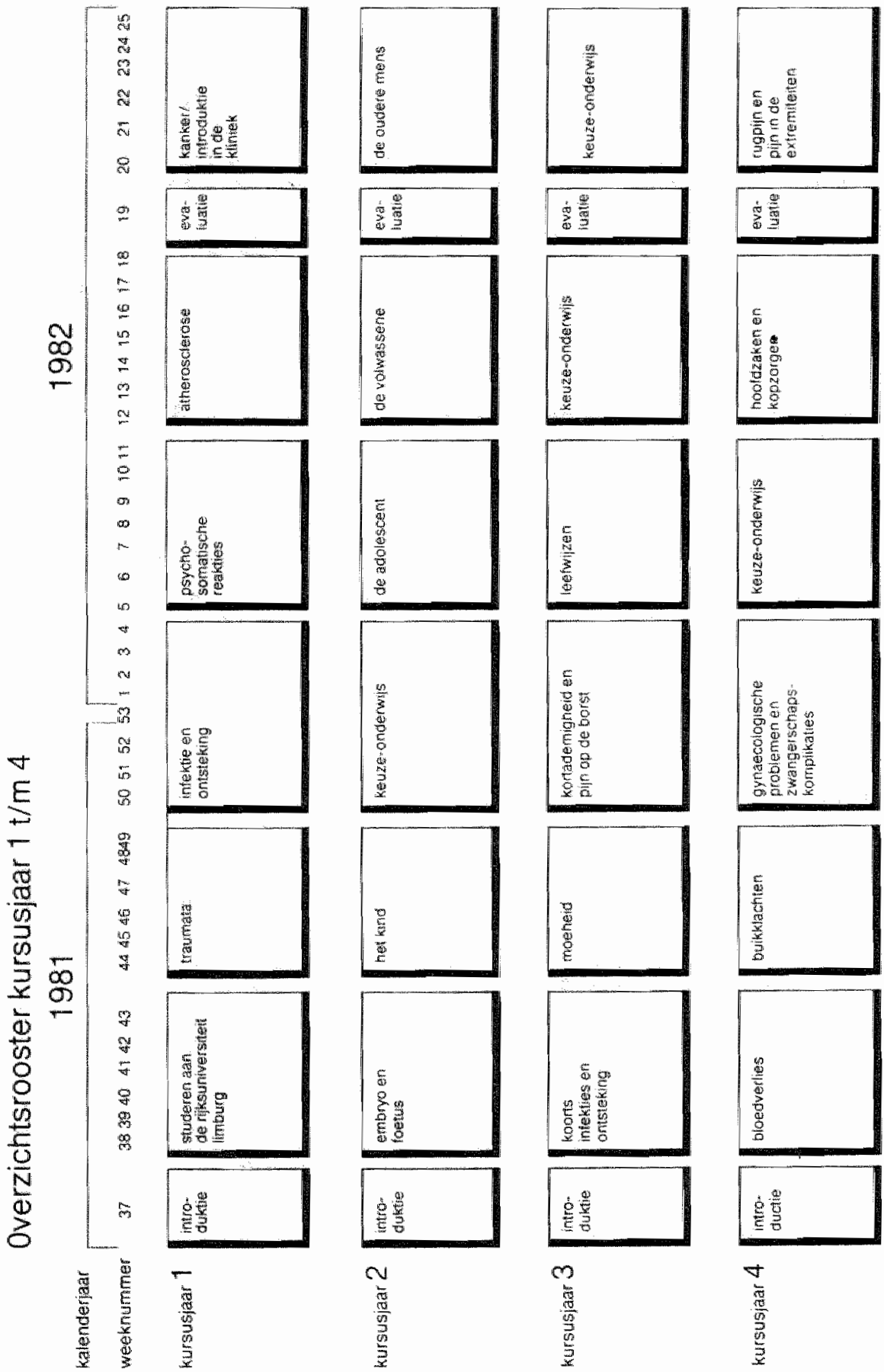
gaan studeren. Daarvoor is een geheel eigen systeem van toetsing ontwikkeld waar idialiter door de student niet naar toe gewerkt kan (hoeft) te worden. Er wordt na elke periode van zes weken (een onderwijsblok) een toets afgenomen waardoor studenten zelf hun kennisvooruitgang kunnen zien (de "bloktoets" of "formatieve toets"). Daarnaast is er een systeem van (summatieve) toetsing (de "voortgangstoets") " Dit is een toets die is opgebouwd ult ca. 250 vragen over het gehele, voor een basisarts relevante, gebled der geneeskunde " Deze vragen worden per toets geput uit een voorraad van vele duizenden vragen. De uragen $z i j n$ verdeeld in dertien categorleën, die voor een belangrijk deel samenvallen met orgaansystemen. Alle studenten van het eerste tot en met het laatste studiejaar maken $z 0^{\prime} \mathrm{n}$ toets vier mal per jaar. Op die wijze kan de voortgang van de student gedurende zijn hele studieperiode, en gerelateerd aan een einddoel, worden vervolgd.

Dit hele onderwijssysteem schept een antal condities die een par belangrifke en positief uitwerkende consequenties hebben voor computersimulatie als leermiddel:

- In het Maastrichtse systeem van probleem georiënteerd onderwijs en zelfwerkzamheid van de student, heeft een CAI-computersimulatieprogramma een "natuurlifkere" ongeving dan in andere systemen van onderwijs en zal computersimulatie sneller geaccepteerd kunnen worden als leermiddel.

- Door het systeem van jaarlijks aangepaste werkboeken ("blokboeken") is het mogelijk om adequaat aandacht te schenken aan het bestaan van nieuwe leermiddelen met betrekking tot de stof war de onderwijspertode over handelt.

- Door het systeem van toetsen na ledere onderwijsperfode (bloktats) is het mogelijk om groepen studenten die wel en die niet met computersimulatie in aanraking zijn geweest te vergelijken.

- Door het systeem van voortgangstoetsen is het ook mogelljk groepen studenten in het verloop van hun studie te vergelifkem.

In hoofdstuk 10 zal op de resultaten die hierblj gevonden werden nader worden ingegaan. Ultwoerige besprekingen van het "Mastrichtse onderwijssysteem" en probleem georlenteerd (medisch) onderwijs zijn te vinden bij o.a. Schmidt, Bouhuys, Wijnen en Neufeld (Neufeld en Barrows, 1974; Tiddens et a1.,1975; Schmidt en Bouhuys, 1977 en 1980; Katz en Fü1öp, 1978-1980; Schmidt, 1978; Wijnen,1981; Schmidt en Bouhuys, 1982; Schmidt, 1982). 


\subsection{Dit proefschrift}

In dit inleddend toofdstuk zijn nu de drie belangrijkste invalshoeken woor de studie over het gebruik van computersimulatie in het probleen georiênteerd medisch onderwijs toegelicht. Uitgaande van deze aspecten kunnen thans de doelstellingen voor deze studie worden geformuleerd:

1. Het onderzoeken van de mogelijkbeden voor computersimulatie als leerinddel in het kader van een probleem georiênteerd medisch curriculum.

Zo'n leermiddel zal moeten voldoen an de volgende eisen:

(a) de computerprograma's moten gebaseerd zijn op probleemsituaties waraan de student zijn inzichten kan toetsen; (b) de probleensituatles zullen moeten ultgaan van probleemstelinger die zijn afgeleld wit de medische praktijk; (c) het leermiddel zal moeten bijdragen tot een beter inzicht in het functioneren wan (onderdelen van) het menselifk arganisme.

2. Het ontwerpen wan een computerconfiguratie voor het uitvoeren van simulatiestudies. Deze configuratie dient coegankelijk te zijn voor medische studenten bij wie géén bijzondere ervaring met computers mag worden verwacht.

3. Het ontwkelen van een goed functionerend algemeen programmasysteem. Ten aanzien van dit systeen mag riet worden uitgegaan van een relatief grote kennis omtrent het gebrulk van computerprogramma"s.

4. Het ontwerpen wan een aantal geschikte modellen op het terrein van de medische wetenschap. Na ontwerp in een geschikte computertaal dienen deze wiskundige modellen te worden gevat in het algemene simulatie software pakket.

5. Het verwardigen van documentathe bij deze simulatieprogrammats zodat een reliatief onervaren person de structur van het model en de mogelifkheden tot simulatie snel kan begrijpen. Bij voorkeur dienen per model relevante medische problemen te worden aangeboden.

6. Het ontwikelen van een evaluatiesysteem om het didactisch nut van een dergelijke vorm van onderwijs te testen. 
Dit proefschrift beschrijft de realisatie van ieder van deze doelstellingen. In hoofdstuk 2 wordt het RL-computersimulatiesysteem beschreven dat ten grondslag ligt aan de meeste van de in de hoofdstuk 3 tot en met 9 beschreven computersimulatieprogramma's. Tenslotte wordt in hoofdstuk 10 een anzet tot evaluatie van dit nieuwe leermiddel gegever en enkele conclusies getrokken in hoeverre aan deze doelstellingen is voldaan.

\section{Referenties en literatuur}

Dit Inleidende hoofdstuk en het volgende hoofdstuk over methoden overlappen elkar zodanig voor wat betreft referenties dat er een gezanenlijke referentielijst is samengesteld. In deze lijst bevinden $z$ lch referenties en literatur over:

- Computer Assisted Instruction (algemeen en i.h.b. medisch en simulatie);

- Modelvorming en simulatie (algemeen en i.h.b. medisch);

- Onderwijs (i.h.b. probleem georiënteerd onderwijs).

Deze referentielijst is opgenomen na hoofdstuk 2 . 
HOOFDSTUK 2

Methodische aspecten t.a.v. Wiskundige modelvorming en computersimulatie

\subsection{Hiskundige modelvorming}

In dit proefschrift worden camputersimulaties aan wiskundige modellen van biologische systemen besproken. Bff de ontwikkeling van deze wiskundige modellen is gebruik gemaakt wan een aantal princlpes uit de regeltheorle. Het is onmogelijk in het bestek van dit proefschrift in te gaan op leder van deze princlpes. Hierwor wordt verwezen naar algemene literatuur over wiskundige modelvorming (Zeigler, 1976; Boersma en Hoenderkamp, 1982). In deze paragraaf zullen enkele van de belangrijkste principes in dit kader worden ingeleld.

\section{Modelvorming en simulatiemethoden}

In de medische wetenschappen kunnen dynamische verschijnselen meestal in de vorm van een stelsel niet lineaire differentlaal vergelljkingen worden beschreven in de vorm $d \bar{x} / d t=\bar{F}(\bar{x})$, waarblj $\bar{x}$ een vector is met $\mathrm{n}$ onafhankelijke variabelen die het proces kan beschrijven en waarbil $\bar{F}(\bar{x})$ n niet linealre functies zijn wan $\bar{x}$. Een dergelijk stelsel vergelijkingen is een wiskundig model van een dynamisch verschijnsel. In de medische wetenschappen is de stap In de modelvorming on te komen tot een stelsel. wiskundige vergelijkingen vanuit een denkmodel (conceptueel mode1) van het dynamisch verschijnsel de meest tijdrovende en gecompliceerdste stap. In hoofdstuk 3 zal aan de hand van één ultgewerkt voorbeeld worden aangegeven hoe dat in $z^{\prime \prime} n$ werk gat. Als een stelsel vergelijkingen cenmal is opgesteld zal dat in de praktijk altijd een stelsel differential (of integraal) vergelijkingen zifn. Het oplossen van een dergelfjk stelsel vergelijkingen is een belangr $1 j k$ onderdee 1 van de modelvorming theorie (Garfinkel et al., 1977, Boersma en Hoenderkamp, $198 \rrbracket$ ). In figuru 2.1 wordt een systemat Isch overztcht gegeven. van de stappen en notatiewijzen die bil deze wiskundige modellen worden gebruikt.

Ultgeschreven ziet dit stelsel niet linealre differential vergelijkingen er als volge uit: 


$$
\begin{gathered}
d x_{1} / d t=F_{1}\left(x_{1}, x_{2}, \ldots . . x_{n}\right) \\
d x_{2} / d t=F_{2}\left(x_{1}, x_{2}, \ldots . x_{n}\right) \\
\cdot \\
d x_{n} / d t=F_{n}\left(x_{1}, x_{2}, \ldots . x_{n}\right)
\end{gathered}
$$

warblj het rechter lid van de vergelijkingen altijd kan worden opgesplitst th een lineair deel en een niet-lineair deel.

Het stelsel kan dan ook in de vorm

$$
d \bar{x} / d t=A \cdot \bar{x}+\bar{G}(\bar{x})
$$

geschreven worden. Een dergelijke uitsplitsing die met name voor stabilteitsonderzoek van belang kan $z i j n$ is over het algemeen bij de hier beschreven modellen en oplossingsmethoden niet noodzakelijk.

Een stelsel differentiaal vergellijkingen $\mathrm{d} \overline{\mathrm{x}} / \mathrm{dt}=\overline{\mathrm{F}}(\overline{\mathrm{x}})$ kan altijd in de worm van een stelsel integraal vergeliykingen worden geschreven $\bar{x}=f \bar{F}(\bar{x}) d t+\bar{x}(0)$ warna het erg overzichtelijk in de vorm van een analoog (stroom) schema kan worden omgezet, waardoor het met name mogelijk wordt om dit stelsel op "algebraische loops" e.d. te controleren. Een model ziet er in de analoge notatiewijze uit als in figuur 2.1 . Deze notatiewljze heeft een rutme plaats in de (biomedische) modelvorming verworven ondat de enige manler on tot voor enige jaren een stellsel differential vergelifkingen op te lossen de analoge computer was. Door de komst van de digitale computer, en met name door de mini-computers met alle mogelijkheden van numerieke oplossingsmethoden woor differentiaal vergelijkingen en simulatletalen, is de analoge computer grotendeeils overbodig geworden en is de wiskundige modelvorming en de toepassing. hitervan in een stroonversnelling gekomen.

De analoge notatiewljee (waarvan de nam nog herinnert aan de analoge computer) is echter vooralsnog gebleven en een aantal moderne simulatietalen (zoals ISL. THTSIM, BIOSIM en CSMP e.d.) gaan nog steeds uit van de begrippen die hierbij zijn ontwikkeld (Algemeen: Kerbosch en Sierenberg, 1973; Ören, 1977. ist: Benham en Taylor, 1977. BIOSIM: Roman en Garftnke1, 1978. SIMULA: Helsgaun, 1980. THTSIM: Meerman, $1980 \%$

In een gimulatietal zou het stelsel differentiaal vergelijkingen er als volgt (zie figuur $2 . \lg$ en h) kunnen uitzien:

$2 \mathrm{ADD}+1,-3$

3 INT $4,+2$

ete. 
waarbif het commando ADD de ingangsvariabele met de "naam" 1 optelt of aftrekt (naar gelang het + of - teken) van de varlabele met de "naam" 3 (dit is de uitgangsvarlabele $x_{1}$ ) en het commando INT de variabele met de "naam" 2 integreert (vanaf de (start) waarde met de "naam" 4). Zie voor de betekenis van de commando's figuur 2.1i. Een programma met dergelijke commando's noemen we een simulatletal. Deze simulatietalen zijn over het algemeen "interpreter talen" die zonder complicatie kunnen worden geëxecuteerd (Benham en Taylor, 1977; Meerman, 1980). Veranderingen in de madelconfiguratie en in de constanten kunnen on-1ine worden aangebracht waarna het uitschrijven van resultaten direct kan geschieden. Dit is de kracht van de simulatietalen. Met name in de ontwikkelingsfase van een modelconfiguratie is dit van groot belang (Min en struyker Boudier, 1979). Ligt de structur wan een model eenmal vast dan is het aambevelingswaardig een dergelijk model in een algemene programeertaal on te zetten zodat het in reeds bestaande programmatuur kan worden opgenomen. Simulatietalen zijn (over het algemeen) nilet geschikt voor verder gebruik wan een eenmal ontworpen model, met name niet in het onderwijs (Guyton et a1., 1972; Coleman, 1978; Dickinson et al., 1979 ; Randa11, 1980).

\section{Regelsystemen}

De in hoofdstuk $3 \mathrm{t} / \mathrm{m} 9$ aan de orde komende modellen $21 \mathrm{jn}$ allemaal van een bepaald type waarbij in de overdrachtsfunctie in de woarwartse weg van het regelsysteem een integratie voorkomt. Uitgaande vam het algemene teruggekoppelde regelsysteem in figur $2.1 \mathrm{~d}$ is $\mathrm{G}$ de overdrachtsfunctie wan de voorwartse, H de overdrachtsfunctie van de terugkoppelweg en G. $\mathrm{H}$ de kring- of lusoverdrachtsfunctle. De systeem overdrachtsfunctie $1 \mathrm{~s}$ dan $G /(1+\mathrm{G}$. H $)$ $x_{0}$ is de ingangsvariabele, streefwarde of "set point". De terugkoppeling van de uitgangsvarlabele $x_{1}$ is proportioneel (nd. H. $x_{1}$ ) en geet een verschilsignaal, of foutsignaal, $c=x_{0}-H \cdot x_{1}$, ara de Ingang van de overdrachtsfunctie $G$ van de woorwardse weg . Voor utgebreide beschouwingen over frequentiekarakteristieken, frequentieresponsmethodes en stabiliteitskriteria wordt werwezen naar de literatur (cf. Zeigler, 1976; Boersma en Hoenderkamp, 1981). Hier worden slechts 2 mogelijkheden belicht, nil. als de overdrachtsfunctie eem type 1 systeem 1. warbij de overdrachtsfunctie $G$ een integratie bevat en als de overdrachtsfunctie een type o systeem is warbij $G$ en H slechts algebraische functles zijn, waardoor "algebraische loops" ontstaan (zie verder in deze paragraaf). 
a. Stelsel niet lineaire dfferential vergelijkingen:

$$
\begin{aligned}
d x_{1} / d t & =F_{1}\left(x_{1}, x_{2}, \ldots . . x_{n}\right) \\
d x_{2} / d t & =F_{2}\left(x_{1}, x_{2}, \ldots, x_{n}\right) \\
d x_{n} / d t & =F_{n}\left(x_{1}, x_{2}, \ldots, \cdot x_{n}\right)
\end{aligned}
$$

b. Vector/matrix notatlewijze:

$$
\dot{\bar{x}}=\bar{F}(\bar{x}) \quad \text { of } \quad \dot{\bar{x}}=A \cdot \bar{x}+\bar{G}(\bar{x})
$$

c. Analoge notatiewijze:
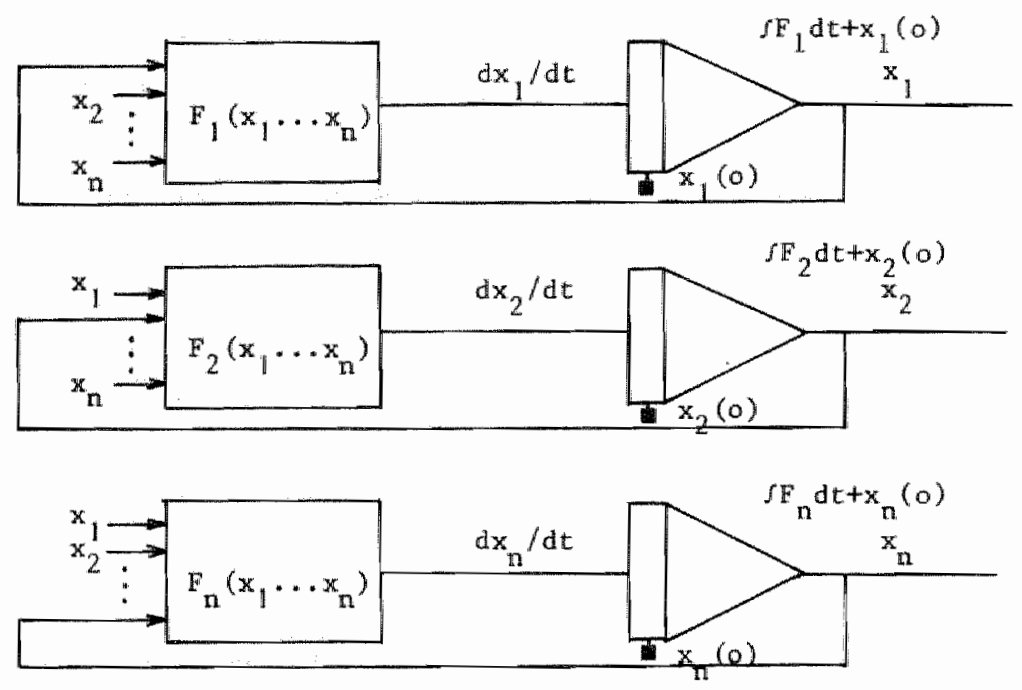

d. Regeltechnische notatiewijze (type o, type 1, etc.):

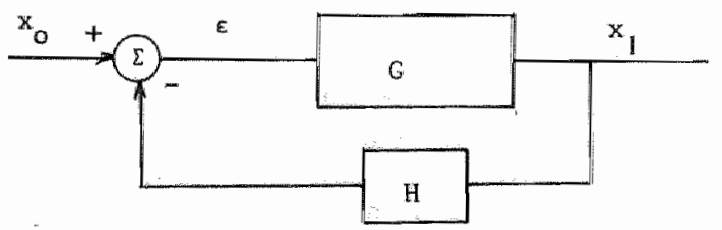

idem voor $x_{2} \cdots x_{n}$

e. Regeltechnische notatiewlye (type 1):

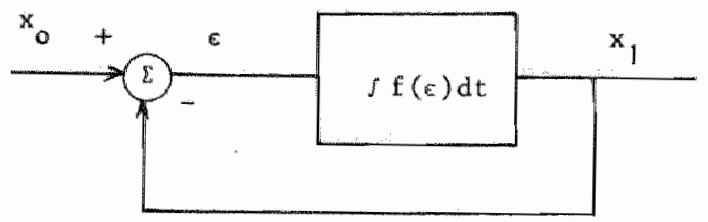

i. dem voor $x_{2} \cdots x_{n}$ 
f. Responsfuncties bif het teruggekoppelde regelsysteem ult Iigur 2. le warbij $G=\operatorname{If}(\epsilon) d t$ en $H=1$ (zie de tekst):

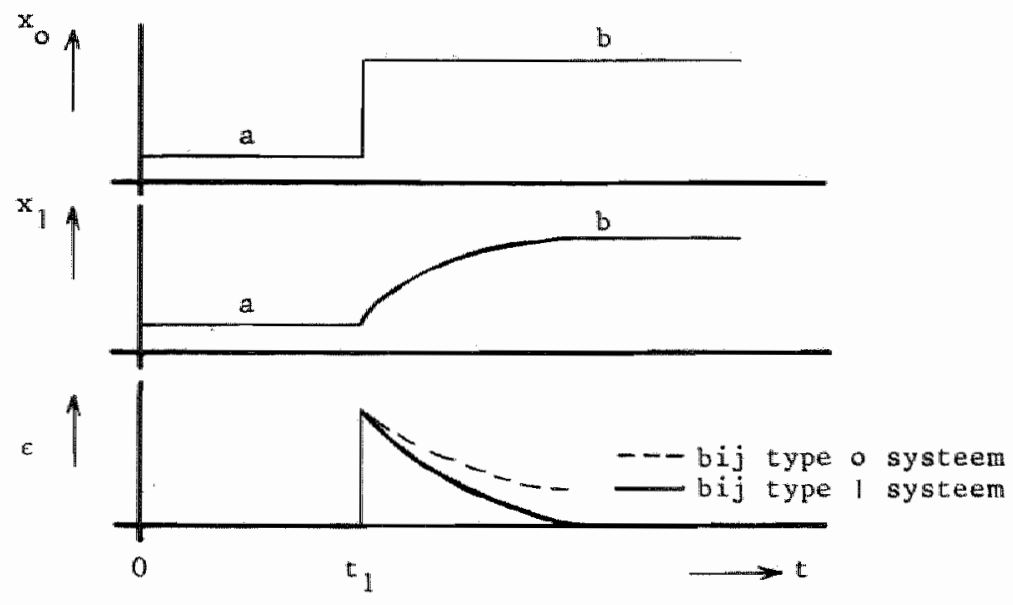

g. Analoge notatiewijze van type 1 systeem om te komen tot de simulatetal notatiewijze

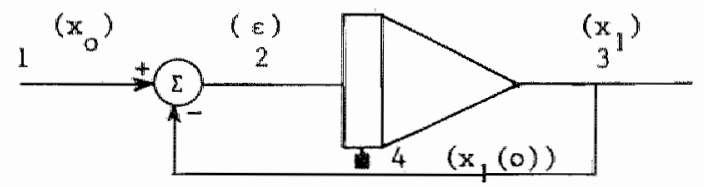
Idem voor $x_{2}=x_{n}$

h. Simulatietal notatiewijze:

$2 \mathrm{ADD}+1,-3$

$3 \operatorname{INT} 4,+2$

idem voor $x_{2} \cdot x_{n}$

i. Verschillende vormen van wiskundige operaties in een simulat letaal. Hier is de analoge notatiewijze gegeven woor 5 basisbewerkingen:

1. voor optellen (en aftrekken) geldt het symbool $A D D$ met $y=2 x_{1}$;

2. voor vermenigvuldigen geldt MUL met $y_{0}=x_{1} \cdot x_{2}$;

3. voor delen geldt DIV met $y_{0}=x_{1} \cdot x_{2}$;

4. voor een niet-1ineaire overdrachtsfunctle geldt FNC met $y_{0}=f\left(x_{1}\right)$

5. voor een integrerende bewerking geldt INT met $y_{0}=x_{0}+\int x_{1} d t$.
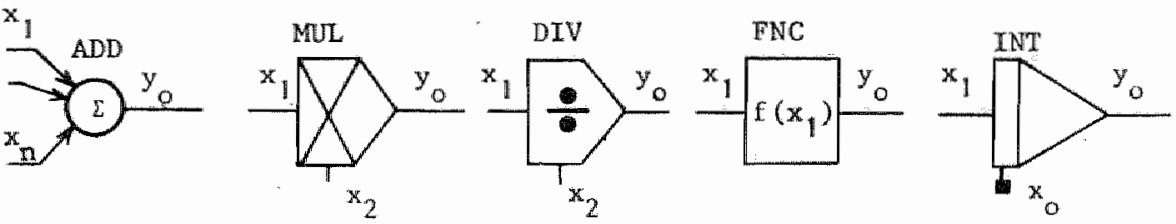

Flguur 2.1.: Verschillende notatewijzen voor het in dit profechrift beschreven type modellen gebaseerd op niet-lineaile differentiaal (integraal) vergelijkingen. 
B1j de hier besproken modellen is de overdrachrsfunctie $G$ in het algemeen $G=f(E) d t$ en de overdrachtsfunctie 1 inealr, of proportionee 1, zodat voor deze beschouwingen $H=1$ mag worden genomen warmee $z^{\prime} n$ effect in de functle $f(\varepsilon)$ kan worden verdisconteerd ( $z$ ie figuur 2. le). Het effect dat optreedt als zich in het model een verstoring, of wat hier genoemd is een interventie, voordoet is een functie van de systeem overdrachtsfunctie en dus ook van de tijd. Een verstoring bij een plotselinge verandering van $x_{0}$ van biyvoorbeeld de warde a naar de warde $b$ veroorzaakt en verschilsignaal $\varepsilon$ dat op het tijdstip 0 maximal is en in de steady state situatie gelijk aan nul wordt. Dit laatste 1 s een zeer belangrijk gegeven bijt de hier beschreven modellen. Zo lang het verschllsignal $\varepsilon$ een warde heeft hoe klefin dan ook zal er geen rustsituatle c.q. steady state zijn (figuur 2.1f). Samengevat kan van een teruggekoppeid regelsysteem van het type 1 gezegd worden dat:

1. de respons op verstoringen aan de ingang met een zekere rijdswertraging aan de uitgang wordt overgenomen (de tijdsconstante is een functle van $G$.

2. het werschilsignaal aan de ingang van het integrerend netwerk 1 s in de steady state situatie altijd nul;

3. In de steady state situatie is de voortgaande versterking bil dit systeem oneindig hoog (zie appendix 2.1);

4. Als geldt dat $x_{1}=\int f(e) d t+x_{1}(0)$ dan geldt ook dat $\mathrm{dx} \mathrm{x}_{1} / \mathrm{dt}=\mathrm{f}(\epsilon)$.

Zie appendix 2.1 voor het begrip "voortgaande versterking" en een voorbeeld van het begrip "galn" uit de biologie.

\section{Numerieke oplossingsmethoden}

Bif de hier besproken modellen worden de numerieke oplossingsmethodem var Runge Kutta gebrulkt: de rechthoekige integratie methode en de 2e orde Runge kutta methode warbij een steunwarde in het midden van de Integratestap wordt benut (Schneider en Rant, 1977; Coleman et a.., 1977a).

De le orde Runge Kutta methode (de Euler methode) heef thet karakter:

$$
y_{n+1}=y_{m}+h \cdot E\left(x_{n} y_{n}\right)
$$

en de 2 e orde Runge Kutta methode (de methode van Heun) heeft het karakter:

$$
y_{n+1}=y_{n}+h\left[f\left(x_{n}, y_{n}\right)+f\left(x_{n}+h, y_{n}+h \cdot E\left(x_{n}, y_{n}\right)\right] / 2\right.
$$

warbij de $h$ de integratiestap is en $y=f\left(x_{n}, y_{n}\right)$ een (le orde) differential vergelijking. 
Voor het computersimulatieprograma MACDOPEX is een 2 arde integratie methode gebruikt en voor de overige computersimulatieprogramma"s de le orde integratie methode van Runge Kutta daar deze voldoende nawweurige resultaten oplevert en de simulatietijd reduceert (Gann et al., 1973; Coleman, 1977; Coleman et al., 1977; Coleman, 1977b; Mackey en Glass, 1977; Garfinke1 et al., 1977; Plant, 1979; Sundaram en Srinivasan, 1979).

\section{Algebraische loops}

Bij een wiskundig model kunnen "algebraische loops" optreden wardoor het stelsel wiskundige vergelijkingen niet meer met de gebruikelijke numerieke oplossingsmethoden is op te lossen. Hierbij dienen veranderingen aan de modelconfiguratie te worden aangebracht. Een vergelijking die niet expliciet kan worden opgelost is een impliciete vergelijking, zaals bijvoorbeeld $x=f(x)$. Dit soort vergelijkingen ontstaat bij, en is inherent aan, bepaalde methoden van modelvorming. En ontstaat dientengevolge in het model een algebraische loop. Een algebraische loop is een "onmogelifkheid" bij een algebraische vergelijking. Bij bovenstaande impliciete vergelijking is het voor de berekening van het rechter lid noodzakelijk on de warde van het linker lid al te weten. Voor een voorbeeld van een algebraische loop wordt verwezen naar de appendix 2.1 .

Een vergelljking kan door een benaderingsmethode worden opgelost maar soms ook door een wiskundige manipulatie (volgorde verandering) in het stelsel vergelijkingen zelf, waarna met de gebruikelijke numerieke methodes de oplossing gevonden kan worden. Positieve algebraische loops met een "gain" groter dan 1 zijn altijd tnstabiel. Negatieve algebratsche loops zljn stabtel, mar bij een relatief grote integratiestap kunnen desondanks instabiliteiten optreden. Er zifn in de meeste simulaticetalen algoritmes opgenomen die algebraische loops opsporen wardoor met een kleine verandering in de modelconfiguratie problemen i i n te voorkomen. Er zijn ook simulatietalen die algoritmes bevatten zodat een programeur in algebraische loops zelf geen modelwijzigingen hoeft aan te brengen (Tavernini, 1965; Elmqvist, 1979).

In het computersimulatieprogramma CARDIo wordt gebruik gemakt van een benaderings methode warbij de iteratieve oplossing (reeksontwikkling) vam het stelsel vergelfjkingen convergeert. Dit verloopt als volgt. Stel dat de iteratieve methode met de berekening van $x$ stopt als de 
Latate term van het iteratieve proces geen wenlijke bijdrage meer levert aan $x$ met een "fout" van $2 \%$. Dus:

stel.

dan 1

Is nu

neem dan $x=x_{\text {stel }}$

$x_{\text {calc }}=f\left(x_{\text {ste } 1}\right)$.

$\|\left(x_{\text {calc }}-x_{\text {ste } 1}\right) \mid / x_{\text {calc }}<0.02$

$k_{\text {ste } 1}=0.95 x_{\text {ste } 1}+0.05 x_{\text {calc }}$

en voer de berekening (2) weer opnieuw uit net zo lang tot aan het criterlum (3) is voldaan. In vergelijking (4) is gekozen voor een "stap" van 0.05 . Blj het ontwilkelen van het model zal proefondervindelijk moeten worden bekeken of deze stap groter (kans op instabllitelt) dan wel kletner (veel iteraties nodig) kan worden genomen (Coleman, 1977b). Er blifft bij deze methode een afwijking t.o.v. de analytische oplossing bestaan. 
2.2. Overwegingen bij de keuze van hardware, software, courseware van CAI-systemen i.w.m. simulatie

Op grond van hetgeen in het inleidende hoofdstuk is besproken $z a l$ in deze paragraaf getracht worden aan te geven hoe bestaande CAI-systemen $z i j n$ geinventariseerd en hoe onderdelen en methodes van systemen $z i j n$ gebruikt bij de ontwikkeling van het RL-computersimulatiesysteen.

De belangrijkste algenene criteria waaraan een simulatiesysteen $t . b . v$. simulatie gebaseerd op wiskundige modellen moest voldoen waren:

1. Geschiktheid woor het onderwijs.

2. Geschikt voor uitwisseling van 'source' van modelien of programma's met andere universiteiten.

3. Geschikt om elgen ideeën en inzichten in het systeem te kunnen aanbrengen.

Achtereenvolgens komen overwegingen aan de orde t.a.v. de programmeertaal, terminalsysteem, computersysteem, ergonomische aspecten en de werkomgewing .

Daarna komt in paragraaf 2.3 een beschrijving van de stmulat lemethode (het RL-computersimulatiesysteem) die gebruikt is om de wiskundige modellen te kunnen ontwikkelen en te presenteren in het onderwijs.

Hogere programmertal, simulatietaal of auteurstaal

Bij de keuze van een programmeertal is eerst studie verricht naar een aantal bestaande CAI-systemen. Een belangrijk CAI-systeem in dit verband was het PLATO-systeem met de auteurstaal TUTOR. Het PLATOsysteem (Programed Logic for Autonomic Teaching Operations), ontwikkeld en beproefd op het Computer based Education Research Laboratory (CERL) van de universiteit van Illinois te Urbana-Champalgn was een van de eerste CAl-projecten en is op grote schaal als methode wan onderwijs verspreld geraakt. Control Data Corporation (CDC) heeft het systeem in samenwerking met het CERL onder beheer en explotteert het met mame in de Verenlgde Staten en Europa en richt zich hierbij zowel op universiteiten als op instelingen, bedrijven, industrieen en de overheid (cf. Alpert en Bitzer, 1970; M. Bitzer en D. Bltzer, 1973; Worster en Lewis, 1973; Fintz et a1., 1976; van Dijk en Avoird, 1979; Camstra et al., 1979; Barker, 1979; Kane en Sherwood, 1980; w.d. Drift et a1., 1980). Het PLATO-systeem is echter niet geschikt voor simulatie met behulp van wiskundige modellen omdat het een zeer 
lafge priortelt voor rekenkundige bewerkingen heeft. Ook is het nut van auteurgtalen nog steeds niet overtulgend aangetoond. Bij het PLATOgysteen 1 s het onmogelijk om in een andere tal dan deze spuecifieke auteurstal het programma te schrijwen.

Hen andere belangrlfke ontwikkeling die in aanmerking moest worden genomen waren de computersimulat Leprograma's van de McMaster Universtty. Het ldee achter deze programa's wordt hier kortheidshalve het McMaster-systeem genoemd. Dickinson, Ingram, Achmed, Sweeney, Gold\$nith, Sacket, e. w ontwkelden aan de Medical School van de McMaster University te Hamilton (Canada) en aan het St. Bartholomews Hospltal te Londen, deze computersimulatieprograma"s t.b.v. het onder wijs. Deze simulatleprograma's zifn zeer bekend geworden mede door werk van Guyton en Coleman In de beginfase van de eerste modelworming (Dickinson et al., 1979; Bloch et al., 1980; Dickinsion et al., 1981). Het doel van de McMaster-computersimulatieprograma"s is niet in de latste plaats om een grote uitwisselbartheid van programma"s tussen universiteften onderling te krijgen, waardoor beoordeling van de kwaliteit văn de modellen door derden mogelijk wordt gemaakt. De programmat' $z 1 \mathrm{jn}$ om deze reden in een algemene programmeertaal geschreven (FORTRAN IV) (Min en Struyker Boudier, 1979, Meijer en Ruifrok, 1982; Saunders et al., 1982).

Het McMaster-systeem is nfet door derden als algemeen simulatiesysteem te gebruiken. Uitslulitend de individuele programma"s kunnen worden geimplementeerd in het medisch onderwijs. Daarvan wordt in hoofdstuk 7 ook een voorbeeld gegeven.

Het idee om een stelsel subroutines special t.b.v. simulatie en CAI op te zetten is in deze studle overgenomen en hierop zal in paragraaf 2.3 b1 d de bespreking van de door ons ontwlkkelde "bibllotheek" van FORTRAN routines worden ingegaan. Achmed, Ingram en Dickinson hebben nasst de bekende computersimulatieprograma"s uit de "MAC-family" ook een algemeen CAI-systeem ontworpen waarin deze programma's kunnen worden opgenomen en en extra dimensie als meer compleet CAI-onderwijssysteen krljgen. Dit MACAID-systeem (McMaster Computer Alded Instructonal. Driwer) is ook in ForTRAN geschreven. Achmed et al. tonen in hun publicatles overtuigend aan warom al hun toepassingen in de algemene programmeertaal PORTRAN 21 jn geschreven (Ingram et al., 1979; Achmed et all., 1980 ). Dit MACAID systeem kan in de toekomst voor compucersimulatie een rol gaan spelen on simulatieprogramm's in "op te menimen" * 
Onderzocht is verder of voor de simulatieprogrammature en systeem van vrije antwoorden of keuze antworden moest worden gekozen. Met name voor het ANAMNESE programma zoals beschreven in hoofdstuk 8 zou een dergelijk systeem in aanmerking komen. Harless ontwiklkelde $z 0^{\prime \prime} n$ systeem (CASE/GENESYS) waarbij studenten een "gesprek" kumnen woren op een "iets natuurlijkere" wijze als met voorgeprogrammeerde keuzemogelijkheden. In de praktijk is het nut van een dergelijke opzet nog onvoldoende aangetoond (Harless et a1., 1971; Camstra, 1980). Wel is het idee van trefwoorden zoals in hoofdstuk 8 wordt beschreven in zekere $z$ in door dit voorbeeld geinspireerd.

In Groot Brittanië zifn veel experimenten gedaan met CAI-simulatieprogramma's in het universitair onderwijs maar dit bleek veelal toch op de terreinen warop al een langere traditie van gebruik van wiskundige modellen bestat zoals in de fysica, de chemfeen tach ook al in de biologie (Hinton, 1978; Hooper, 1978; Laurillard, 1978; Mckenzie et al., 1978). Deze projecten bleken veelal op BASIC gebaseerd te $z 1 j n$, wat wel garant stond voor een adequate uitwisseling tussen universiteiten en verschillende computersystemen, maar de ontwikkeling narar grote wiskundige modellen op het biomedische terrein waarschijnlijk in de weg stond. In Anerika bleek het systeem wan Coleman en Guyton om modelvorming en simulaties uit te voeren grote flexibiliteit voor zowel de ontwerper als de gebruiker van de modellen in te houden. Bij dit SIMI/2 (ASP)-simulatiesysteem (Fortran programs for simulation of continuous systems 1 en/of 2; voorheen: Analytic Study Package) vindt modelvorming met FORTRAN IV plaats. Dit interaktief simulatiesysteem werkt met een groot aantal "optles" Cof "modes" zoals deze in paragraaf 2.3 worden genoemd) die een onderzoeker een grote vrijhefd geeft om te kunnen experimenteren met modellen. Het SIMI/2(ASP)-systeen met zi jn wele mogelifkheden voor modelvorming en simulatie is echter alet geschikt als simulatiesysteem voor studenten.

Evenals simulatietalen zoals İSL (Benhan en Taylor, 1977) of THTSIM (Meerman, 1980) kan SIMI/2(ASP) niet tot CAI gerekend worden vanwege de kennis die nodig is on met het systeem te kunnen werken. Besloten is om een CAI-computersimulatiesysteem te ontwikkelen dat special moest dienen om studenten in de gelegenheld te stellen zelf computersimulatiestudies te kunnen laten doen.

Bij onderwijs research projecten aan universiteiten is een zekere vrijheid van handelen, om in bestaande CAI-systemen te kunnen ingrijpen. of nieuwe CAI-systemen te kunnen opzetten, van fundamenteel belang voor 
het onderzoek. Bovendien zou een sollstische orlëntatie op éen bepald CAI-systeen in het huldige stadium van technische ontwikkeling en kostenverlaglng een onderwijsregearchproject kwetsbaar maken.

Wat betreft de programeertaal warin het systeem moest worden geschreven viel de keuze op FORTRAN IV:

- Ten eerste on de uftwsseling tussen universitelten (m.n. Medical Schools) te vergemakkelijken; FORTRAN is systeemonathankelijk.

- Ten tweede ondat madellen in de biomedische wetenschap nog steeds grotendeels in FORTRAN worden geschreven (zie de publicaties van Coleman, Guyton en Ikeda, etc.).

- Ten derde ondat het systeen van het "tekst-statement" (FORMAT) in BORTRAN is te omzellen met een systeem van "tekstfiles" ("editable text files').

- Ten vierde omdat het noodzakelijk is modellen kritisch te kunnen laten onderzaeken door derden, en tenslatte omdat

- algemene CAI-systemen zoals PLATO, COURSEWRITER, CASE, maar ook programmeertalen zoals MUMPS en BASTC, de mogelijkheid missen om efflctent computerstmulat leprograme's gebaseerd op wiskundige modellen utt te wiselen tussen computersystemen die onderling (sterk) verschillen.

\section{Terminalsysteem}

Een tweede keuze dle gedaan moest worden betrof het terminalsysteem. ook hier kont het voor het PLATO-systeem (Plasma-terminals en type ISTterminals) het probleem dat dergelijke terminals niet los gezien kunnen worden van het gehele systeem en dus nlet in aamerking komen. Veel firma's leveren inmidels terminals met de kwaliteit grafische oplosbaurhed en en stabiel en flikkervriy beeld) die vergelijkbaar is met PLATO.

Bif het McMaster-systeem wordt gebrulk gemakt van een gewone alfanumerteke terminal warbij voor de grafische uitwoer gekozen is voor de primitieve manter van printen wan een karakter op een van de 80 posities die op een regel mogelijk zijn. Hierdoor is het McMastersysteem wel onafhankelifk van grafische en cursorsturings software pakketten.

Coleman en Darby hebben voor hun SIM1/2(ASP)-systeen gekozen woor een apart gratisch systeen van Tektrontix nast een alfanumerieke terinfmal. Fen dergelt the twe e-terminal systeem is wok woor het RL-compulerstmulatiesysteem gekozen ondat een dergelijke opstelling nast andere 
zeker ook onderwijskundige voordelen bledt. Daarbj komt dat dit systeem dicht in de buurt van een laboratoriumopstelling voor het meten en regitureren van variabelen aan een proefopstelling warbij expertmenten kunnen worden gedaan aan een "proefpersoon" *

Registraties op een deel van een beeldscherm terninal en met een compum tersimulatieprograma interaktief werken op een ander deel van dezelfde beeldscherm terminal is zoals bif onze experimenten gebleken is, voor onderwijsdoeleinden niet de meest aan te bevelen methode.

Sinds enkele jaren levert de firma Digital Equipment Corp. (DEC) een speciaal terminalsysteem GIGI (General Inaglng Generator and Interpreter), speciaal ontworpen voor het onderwijs. Dit systeem is belangrijk vanwege de lage kosten en omdat het naast een vergelijkbare beeld w resolutie als bij PLATO ook met kleuren kan werken en met gewone programeertalen besturbaar is (Digital B.V., Utrecht). Dit beeldscherm systeem komt zeker in aanmerking als grafisch ultvoer medium voor computersimulatieprogramma's. Er is echter nog weinig bekend van ervaringen met simulaties en thet gehele hard- en software systeem. Voordisnog, en mede gezlen de vele positieve ervaringen, is bij het prototype van het RL-computersimulatiesysteem gekozen voor een Tektronix teminal en een standaard alfanumerieke terminal van DEC. Met name om binnen de universiteit compatibel te blijven met de overige apparatuur.

\section{Centraal systeem versus decentraal systeem}

Enkele voorkomende configuraties van CAI-systemen:

1. Een algemeen centraal systeem met "multi user operating system" (zoals bij het SLML/2(ASP)-systeem).

2. Een central systeem met "multi user operating system" uitslultend voor CAI (zoals bij PLATO-systeem).

3. Een mini- of microcomputer met "single user operating systen" (zoals bilj RL-computersimulatiesysteem).

4. Een centraal systeem met gekoppelde mint- of microcomputers (zoals bij MICroplato-systeem).

Op een algemeen central computersysteen waar zowel programa-ontwikkeling op moet plaatsuinden als produkt leprogramma"s op moeten worden gedraald, kan slechts onder zeer bijzondere voorwarden een CAl-project worden opgezet. NHet zo zeer het ontwikkelen wan een CAI-systeen of don CAI-programa is een probleem op een dergelijk computersysteen, matr het systeem te laten functioneren in het onderwijs geeft vooral problemen. Ten eerste is een CAl-project altijd een geheel nieuw project en 
komt een dergelijke aktivitelt boven op bestaande computeraktiviteiten watdoor de kans van overbelasting van het computersysteem wordt vergroot. Ten tweede is een terminal en een terminalomgeving niet direct vanzelfsprekend een rust 1 g gesitueerd leerstation. Ten derde moet er rekening worden gehouden met gebrulkers die nog nowt eerder met een computersystem hebben gewerkt. Dan zijn er tenslotte nog de problemen van responstijden en de prioriteit die een CAL-programa krijgt op het systeem. Het is vooral een kwestie van systeembeheer, dat een CAI-projectgroep eigenlijk zelf in de hand moet hebben, zeker in de opstartfase. Bij een centraal systeem, uitsluitend voor CAI, zijn de voorwarden die vanult onderwijskundig opzicht aan een systeem worden gesteld beter te beheersen. Een probleem kan dan nog wel bestaan bij de prioritelt tussen mensen die bezig zijn CAI-programma's te ontuikkelen (programma"s complleren, testen of m.b.v. proefpersonen experimenteren) en het gebrulk van CAI-programa"s in het currlculum. Daar ait ten nog wel tegengestelide belangen in. Gekozen is dan ook voor configuratie 3 met de mogelijkheld on over te stappen naar conflguratie 2. Als mogelijk nadeel bij deze opzet kan genoemd worden een eventuele leegstand van een dergelfjk CAI-systeem in de vakantieperioden. De keuze bij het prototype van het RL-computersimulatiesysteem viel uitelndelijk op een MINC 11 computer.

\section{Machine-Student aanpassingen en responstijden}

De interaktie tussen de student en een computersimulatieprogramma wordt voor een groot deel bepald door de dlaloogvorm van het programa en de responstijden van het systeem. Bij een centraal systeem moet een CAT-systeen ontwerper erop bedacht zijn dat nieuwe computersystemen in het begin onderbezet zijn, bestanden zijn (nog) optimaal georgandseerd en het aantal transaties is nog gering. Er komen ook voorturend hogere elsen bij woor bevelliging. Als er een situatie van "overbelasting" ontstaat lopen vanaf zo"n moment de responstijden exponentieel op (Craenen, 1981). Door ergonomisch onderzoek van o*a. Faddegon (1981) en Nievergelt (1980) is naar voren gekomen:

- dat de student ten alle tijden overzicht moet hebben over wat het systeem voor hem doet;

- dat de student het gevoel moet hebben dat hil het systeem bestuurt;

- dat het beeld dat de student van het model heeft nter verstoord of getrustreerd wordt door het systeem;

- dat geconpllceerde handelingen de student afleiden van de eigenijke 
taak: het oplossen van een probleem;

- dat er duidelijke en eenduidige instructiehandleidingen moeten zi In;

- dat er voor geoefende gebruikers kortsluitingsmogelijkheden moeten bestaan on dialooggedeelten over te slaan;

- dat de grootre van een invoerveld op een beeldschermpagina of in een beeldscherm formulier moet worden opgegeven;

- dat "scralling" zoveel mogelijk vermeden dient te worden:

- dat het geen probleem is dat een wachtijd lang is, als het maar duidelijk is dat een daarbij behorende functle complex is en een lange wachttigd "nodig" heeft;

- dat wachtijden in gelijksoortige situaties gelijk dienen te $z i j n$;

- dat het vermelden van m.n. lange wachtijden aanbeveling verdient;

- dat een te snel systeem een opgejaagd gevoel kan geven;

- dat de gebruiker over het algemeen begrip heeft voor lange wachttijden bij "dingen" die hem ingewikkeld lijken en ook ingewikke1d zijn;

- dat het bij lange en voorspelbare wachteijden mogelijk is andere aktiviteiten te laten platsvinden. De student kan nieuwe leerdoelen wastleggen, de modelbeschrijuing bestuderen, etc.;

- dat responstijden die niet eenduidig zijn of blijven tijdens simulaties of animaties niet dienen voor te komen (schokkerig effect tijdens tekenen dient vermeden te worden).

(Nievergelt, 1980; Faddegon et al., 1981 en Craenen, 1981).

\section{Werkomgeving}

Tenslotte dient voordat wordt overgegaan naar een beschrijulng van het eigenlijke RL-computersimulatiesysteem, bij de opsomming van alle methodische aspecten, enkele opmerkingen te worden gemakt over de gekozen werkomgeving warin de studenten bezig zijn met computersimulatie:

- het computersimulatiesysteem bevind zich in een rustige rujnte war werder geen aktiviteiten plaatsuinden;

- in deze "onderwi.jsruinte" bevinden zich de "flloppy disks" met de programma's:

- er Iigt een handlelding over het RL-computersimulatiesysteem speciaal t.b.v. de studenten;

- er liggen modelbeschrijwingen van alle modelten die in het $\mathrm{Kl}^{-{ }^{-C} \mathrm{Com}-}$ putersysteem ziln opgenomen;

- er liggen diverse casusbeschrijvingen ("werkpapieren") dle de studenten kunnen gebruiken (voor enkele voorbeelden hiervan wordt verweren naar de appendices); 
- er zijn enkele naslagboeken in de onderwijsruimte aanwezig;

- in de eerste 10 à 15 minuten wan een sessie is een begeletder aanwezig om studenten wegw simulat leprogramma" s;

- er is een inhoudsdeskundige (c.q. vakdocent) beschikbaar die op het einde van een sessie in ongeveer een kwartier de casuistiek nabespreekt met de studenten. De belangrijkste functie van de valkdocent bestat wooral in het formuleren van relevante onderwerpen voor verdere studie. 


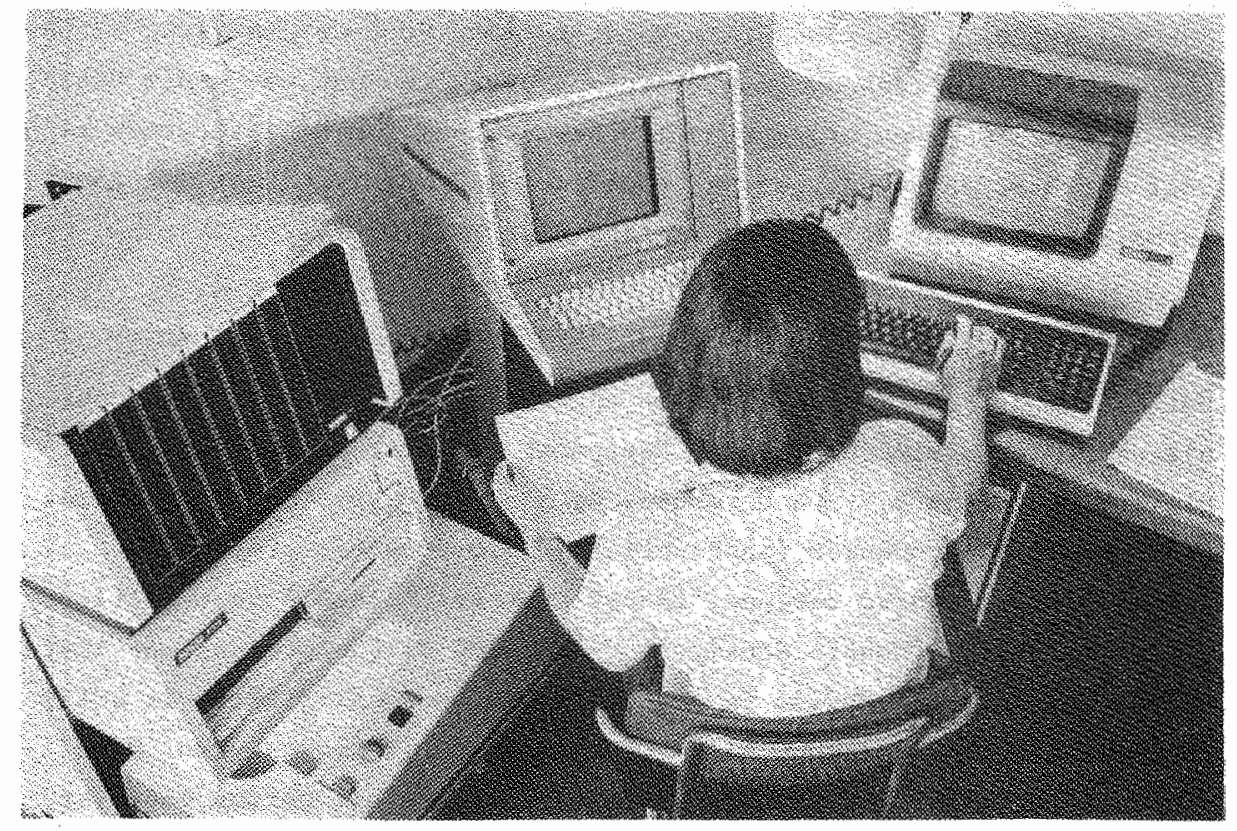

\subsection{Beschrijving wan het RL-computersimulatiesysteen (RLCS-systeem)}

Op grond van de in paragraar 2.2 besproken methodische aspecten en argumenten is ulteindelijk het RL-computersimulatiesysteem tot stand gekomen. Het RL-computersimulatiesysteem zoals dat wanaf 1978 is ontwikkeld aan de Rijksuniwersteit Limburg is een simulatiesysteem warmee feitelijk eien laboratoriumsituatie wordt nagebootst. Resultaten van experimenten met een proefpersoon (gepresenteerd door wiskundige modellen) kunnem worden geregistreerd op een grafisch witvoermedium. Het gehele tweeterminal sinulatiesysteem is gerealiseerd op een minicomputer met enerzijds een standaard terminal voor de interaktle met het programma en het doen van interventiles aran het model en anderzijds een graflsche beeldschermterminal voor thet weergeven wan de resultaten, woals in paragraaf 2.2 is beargumenteerd. De programmatur is in FORTRAN geschreven zoals bij het McMaster-systeem. Voor de beeldschermindeling en programabediening is gekozen voor een door ons ontwikkeld cursor- 
wturings annex beeldschermformulier-systeem met een speciaal voor de student ontwkkelde "help-optie". Het stmulatieprogramma zelf heeft het modelgedeelte volledig gescheiden van de simulatieprogramatur zoals ook bif het SMMI/2(ASP)-systeem wordt gedaan. Voor de grafische ultvoer is een gangbaar graflsch systeem (Tektronix) gekozen met een grote beeldresolutie en met een storage beeldschermsysteem. In de literatur zifn veel voorbed lden van dergelifjke twee-terminal systemen (met Tektronix) vermeld, o.a. door Colleman en Sparkes (Sparkes, 1979).

\section{Hardware van het R-computers imulatiesysteen}

Het RL-computersimulatiesysteen is opgebouwd rondom een minlcomputer uLt de POP 11 serie van Digital Equipment Corporation (in Nederland: DIgital. Equipment B.V. te Utrecht). De mini-computer, een MINC 11 met een PDP 11/03 processor (instructietijd: 10-20 psec; processor: 64byte) is uftgevoerd met een 'floppy disk untt' (RXO2) voor 2 'floppy disks' (1 Mbyte; 'double density') en een DEC VT105 terminal met 'keyboard! "Als uitwoer medium is een graflsche terminal (Tektronix 4012, storage) met een 'hardcopy unit' (Tektronix 4631) aangesloten. Deze graflsche terminal kan ook als ("operator') terminal worden gebruikt 1.p.v. de VT105 termina1, mar in de huidige opstelling, als grafisch uftroer medium, wordt hij alleen voor uitvoer doeleinden sebrulkt en is het toetsenbord buten gebruik gesteld. De VTLO5 terminal wordt alleen voor alfanumerieke doelelnden gebruikt. De grafische mogelijkheden van deze VT105 terminal worden niet gebruikt, wel de cursor sturingsmogelijkheden. Hierdoor is de VT105 uitwisselbaar gebleven met de VTI00 terminal. Het toetsenbord van de VT105 terminal staat los van thet beeldacherm en heeft een toetsenborddeel voor ciffers en een normal. typemachine toetsenborddee1. De grafische Tektronix terminal is uitgerust met een storage beeldbuis, warbij een punt als het eenmal is geschreven op het scherm blifft staan zonder dat er een interne geheugenplats nodig is om de informatie op te slan. De prog amma"s en de files staan op één enkele floppy disk, de studentengegevens stan op een andere, aparte foppy disk. Het gehele simulatiesysteem kan direct op een ander computersysteem geimplementeerd worden op enkele systeen-subroutines na zoals de interrupt subroutine, de 1/0-subroutine t.b.v. de Tektronix en de cursorsturingssubroutines. $\mathrm{Er}$ is van het RL-computersimulatiesystem en versie ontwlkkeld voor een VAX 11/780. Dat is eveneens een twee-terminal-versie, echter met een VTLOO terminal. 


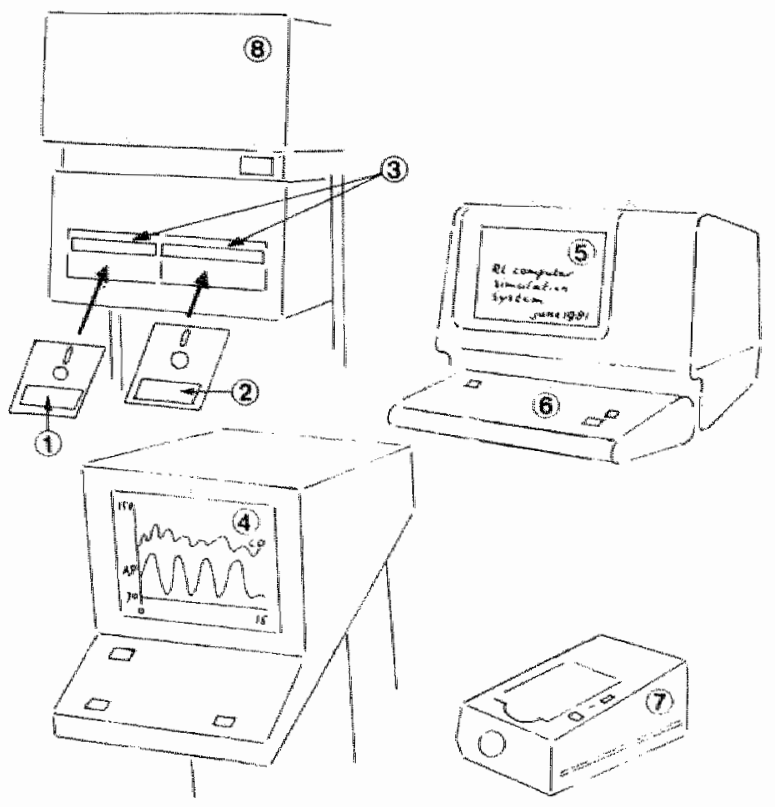

Figuur 2.2.: Het-RL-computersimulatiesysteem.

1. Schijf met computersimulatieprograma

2. Schijf met de studentengegevens in resultatenfiles

3. Floppy disk units

4. Grafische beeldschermterminal

5. Alfanumeriek beeldscherm

6. Toetsenbord

7. Hard copy unit

8. Computer

Sortware van het RL-computersimiatiesystem

Het RL-computersimulatiesysteen makt gebruik wan een pakket graflache subroutines, PLOTIO, voor de Tektronlx besturing. Het "operating system', RTl1 (vOJFB), is een "zingle user', 'foreground/background" systeem. Het RL-computersimulatiesysteem is gebaseerd op een spectal. door ons ontworpen en ontwikkeld, voor CAI en simulatie geschilt, pakket subroutines (MINLIB), een pakket cursorsturingsroutines (VIIOO) en enkele specifieke RTIl subroutines (voor o.a. 'interrupting', 'keyboard-locking', 'chaining', in- en uitvoerroutines $t$, b. w. Tektronix). Aan de orde zullen komen de functie die een programma in het systeem vervult, de programma indeling en de afzonderlijke data- en cekstiles van het RL-computersimulatiesysteem. 
Functe van atzonderlijke programais in het system

Central in het programmasysteem is het keuzemonent dat na afloop van ledere bewerking optreedt (de "inhoudspagina" of "menukaart"). Op dit centrale punt in het programiasysteem kan worden gekozen voor een van de hoofdbewerkingen of voor een van de subbewerkingen (hier "modes" genoend) (zie figutur 2.4).

Deze "modes" $z 1 j \mathrm{in}$ onderverdeeld in 7 hoof dbewerkingen $(1: 1,11,12$ en 13 ; 2: 2 en $22 ; 3: 3,3.1,3.2,3.3$ en $3.4 ; 4: 4.14$ en $15 ; 5: 5 ; 6: 6$ en tot slot: 0j. Deze hoofdbewerkingen die de student op dat moment heeft zijn:

1. Het "veranderen" van een grootheid zoals modelconstanten (mode 11), schalinstelingen (mode 12) of diverse programmagrootheden (mode 13) (dit wordt uitgevoerd door het programa VERAND).

2. Het "doorgan" met de modelanalyse vanaf een tijdstip kleiner dan de ingestelde maximale rekentijd (mode 2) (programma Door) alswel vanaf het tijdstip dat de maximale rekentijd is bereikt (mode 22). In dit laatste geval worden er eerst op het graflsche beeldscherm nieuwe kaders getekend (programma START) en doorgegaan met de modelanalyse (programma DOOR).

3. Het nauwkeurig "inspecteren" van grootheden zoals de 8 ingestelde varlabelen die worden getekend (mode 3.1 ), alle modelconstanten (mode 3.2), diverse progranmagrootheden (mode 3.3) en alle modelconstanten die $t a . v$. hun normale warde meer dan een bepald percentage afwijken (mode 3.4) (programma INSPEC). Deze mode makt het tegelijkertijd mogelijk dataflles aan te maken die gebruikt kunnen worden als casus. Daartoe kan door de docent een datafile (RESTAR.NEW) worden gemakt en worden omgezet ('renamed') tot een casus-ille.

4. Het "herstarten wan een proefpersoon" met behoud van de schalal- en tifdsindeling (mode 14), het kiezen van een patelentencasus met speclaal tingestelde tijdschal en belangrljke vartabelen (mode 15), of het opriteub beginnen met het gehele programa warbij alle modelen programagrootheden weer op hun ultgangswatrden worden teruggezet (programa START). Dit latste kan ook rechtstreeks met mode 5 gedáan worden.

5. Het bele computersimulatieptogramma opnteuw "starten" warbij alle mode1- en programmagrootheden weer op hun tuitgangswarden worden teruggezet (mode 5) (programa START). 


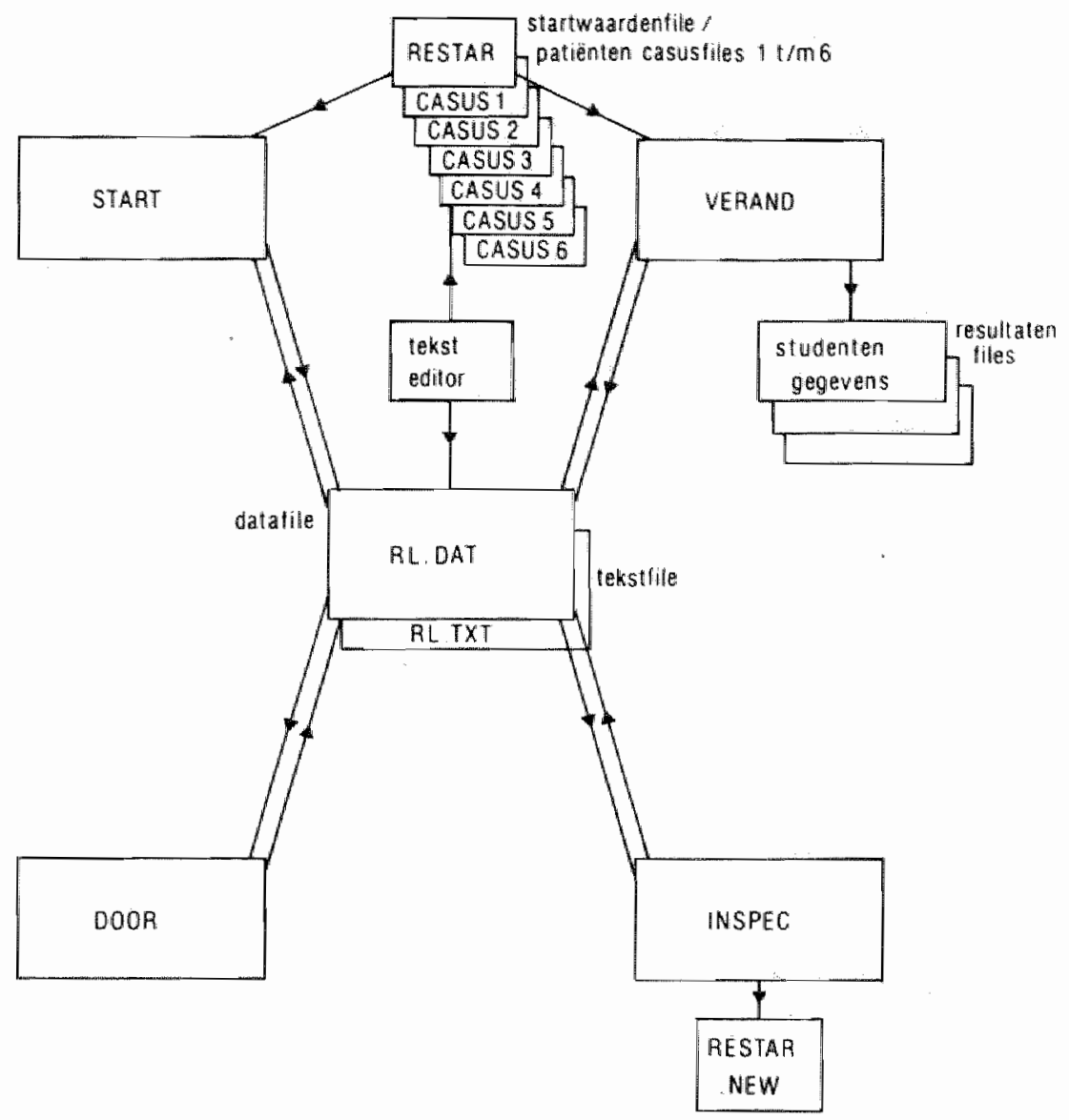

Figuur 2.3. : Relatieschema van de programmatuur van het RL-computersimulatiesysteen met de 4 progranma's START, DOOR, VERAND en TNSPEC en de afzonderlifke flles.

6. Het "corrigeren" van het gesimuleerde op het grafische beeldscherm vanaf de laatste onderbreking (mode 6). In dit geval wordt er na een onderbreking van de simulatie geen nieuwe dataflle met simulatiedata aangemaakt. De aanwezige file wordt niet overgeschreven maar er wordt uitgegaan van de oude simulatiedata van het tijatip van de laatste interruptie wardoor er in wezen een stap wordt teruggezet in de tijd en de student de mogelijkheld heeft alsnog lecs anders te proberen. De situatle kan zich voordoen dat "de patient. 
is overleden" dan krljgt de stuilent nog de gelegenheid "iets anders" te doen. Het programa kome dan automatisch in de mode 1 (iets veranderen) (programma VERAND).

7. Stoppen met het computersimulat leprograma en computer witzetten (mode 0 ).

op the beeldscherm ziet de volledige inhoudspagina er als volgt uit:

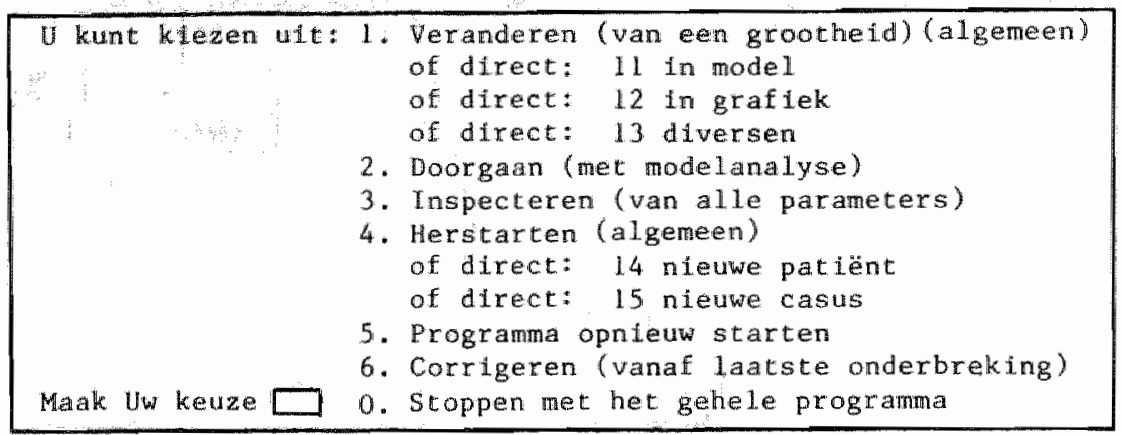

Zhe figuur 2.4 voor de ultwerking die het maken van een keuze op deze plats theeft.

\section{Het_programina START}

Dit programma begint met de "titelpagina" (mode 0.1 ) wan het computersimulatiemodel warin wordt verteld wat voor soort model aan het sirmulatheprogramma ten grondslag $1 \mathrm{igt}$, wie de auteurs $z 1 j n$, wie de arspronkelijke ontwerpers $z i j n$ en welke unfversiteiten en instellingen bij het tot stand komen van het programma betrokken zijn geweest. Op de volgende pagina (mode 0.2) wordt de student duidelijk gemaakt hoe met het toetsenbord lets kan worden ingetypt, gewist en hoe uiteindeIIjk een commando wordt uitgevoerd. De student heef een hele regel on een vrlje tekst (b.v. nam en datum) in te vullen. De volgende pagtna verklate wat voor varlabelkn er op thet scherm getekend zullen worden (mode 0.3 ) en dan komt het keuzemoment, de inhoudspagina, weet.

\section{Het Lograma DOOR}

Het programia leest de simulatiedata $\bar{x}_{\mathrm{n}}$ wit de datafile en berekent de nlevwe warden $\bar{x}_{n+1}$ wratbij $t_{n+1}=t_{n}+\Delta t$ ( $\Delta t$ is integratiestapgrootce). Det gat doom tot de maximal ingestelde simulatietijd of de ingestelde looptijd is berelkt of tot de student de simulatie onderbreekt. Dan verschint de Inhoudspagina op het beeldscherm en worden de simulatiedata in de datafile weggeschreven en worden de programa's START, 


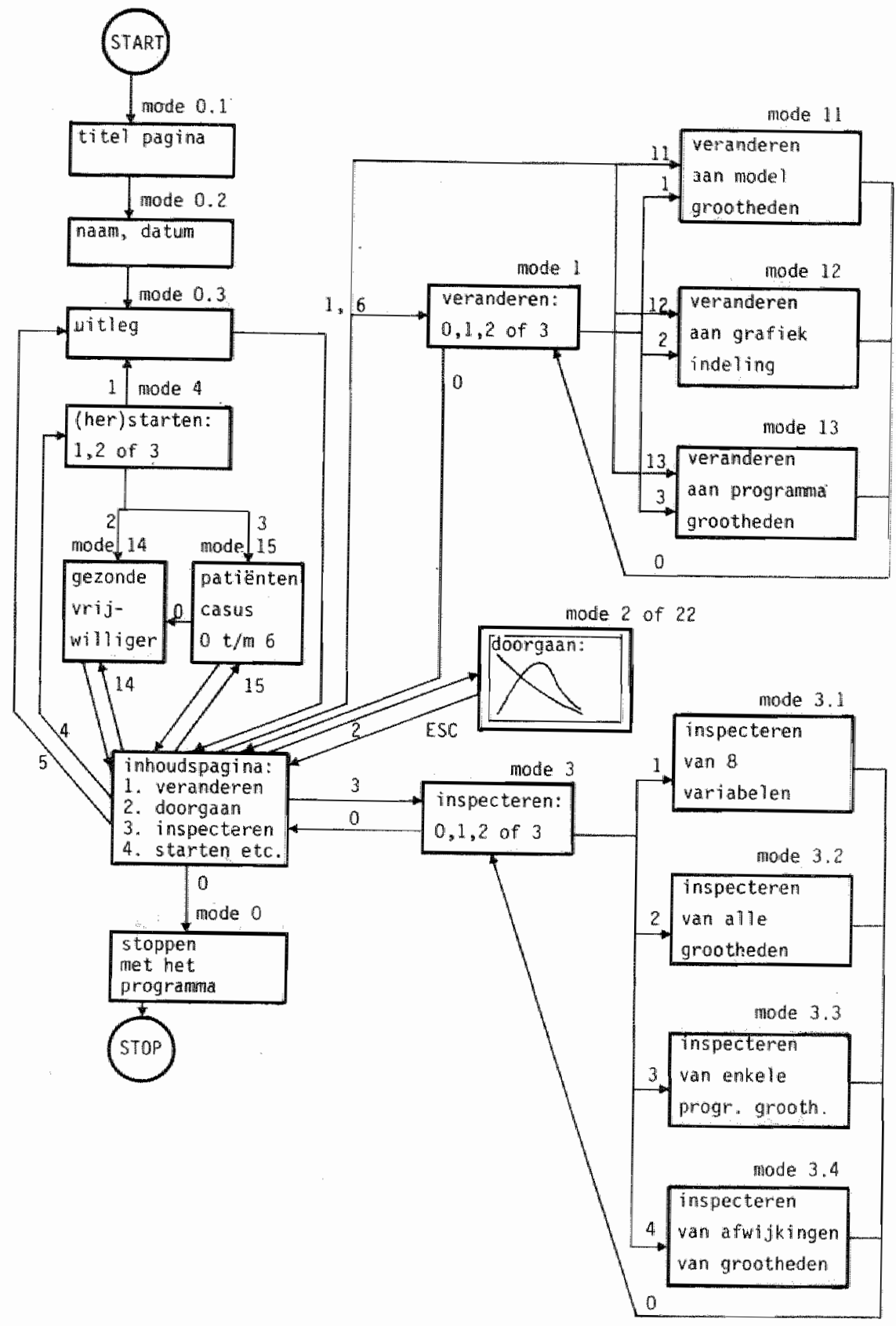

Figuur 2.4.: Vereenvoudigd blokschema van het RL-computersimulatiesysteem met 17 verschillende (sub)bewerkingen of "modes". De modes zijn: $0,1,2,3,4,5,6,11,12,13,14,15,22,3.1,3.2,3.3$ en 3.4 . Modes 0.1 en 0.2 worden niet als bewerking gezien; mode 6 is als het ware mode 1 en $0.3 \mathrm{kan}$ worden beschouwd als mode 5 . 
INSPEC of VERAND aangeroepen. Alleen als de student kiest voor het "corrigeren" van zifn handeling worden er geen data weggeschrewen. Het programa valt dan terug op de data van het laatste interruptiemonert.

\section{Het_Rrogramima VERAND}

Dit programa wordt angeroepen als de student lets wil veranderen aan de stmilatidata. De datafile wordt gelezen; de verandering, die op 3 manieren kan worden ultgevoerd, wordt in de data angebracht en weer in de dataf1le weggeschreven. Dit dit programasysteem is gekozen voor een systeem van oproepen van een grootheid door het intypen van een naan wan maximal 4 karakters. De modelparameters hebben in de FORTRAN notatlewljze een unleke naam van 1 tot 4 en ten hoogste 6 karakters (mnemomic code). Het eenvoudigste is deze mnemomic cade in de modes 11 en 12 van dit programma te gebruiken. Alleen in mode 13 van dit programna wordt aen programmagrootheid niet veranderd door het intypen van een naam maar door het klezen van een nummer. Als voorbeeld is hter de beeldscherm paglna (c.q " beeldscherm formulier) van mode 12 gegeven.

De aanwezige vartabelen met hun maxima en hun minina zijn de volgende:

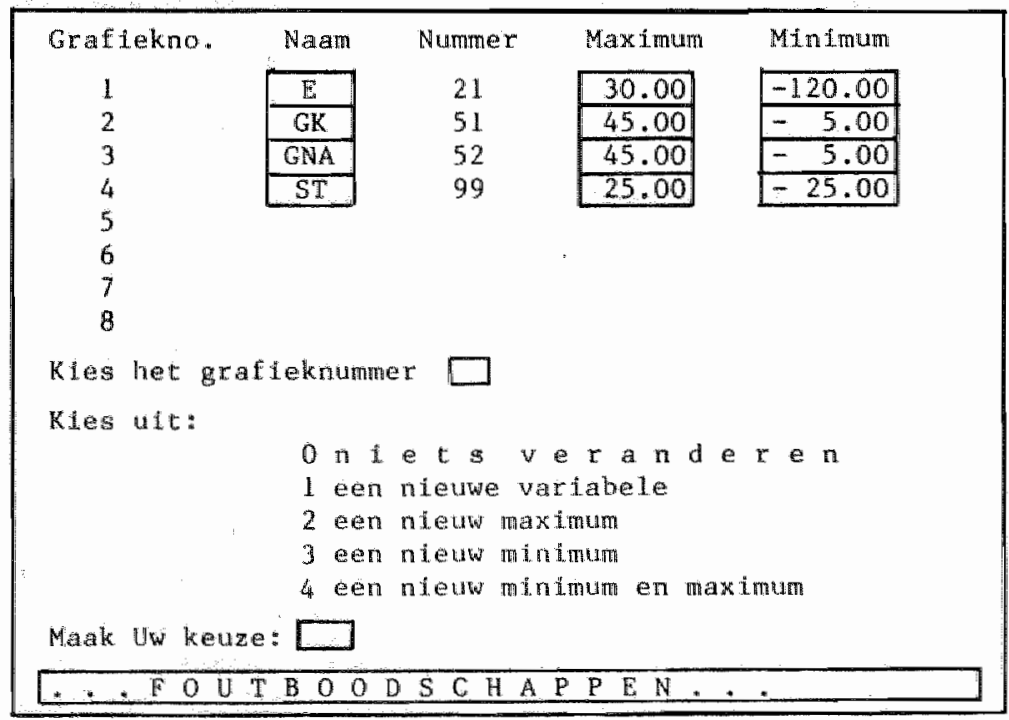




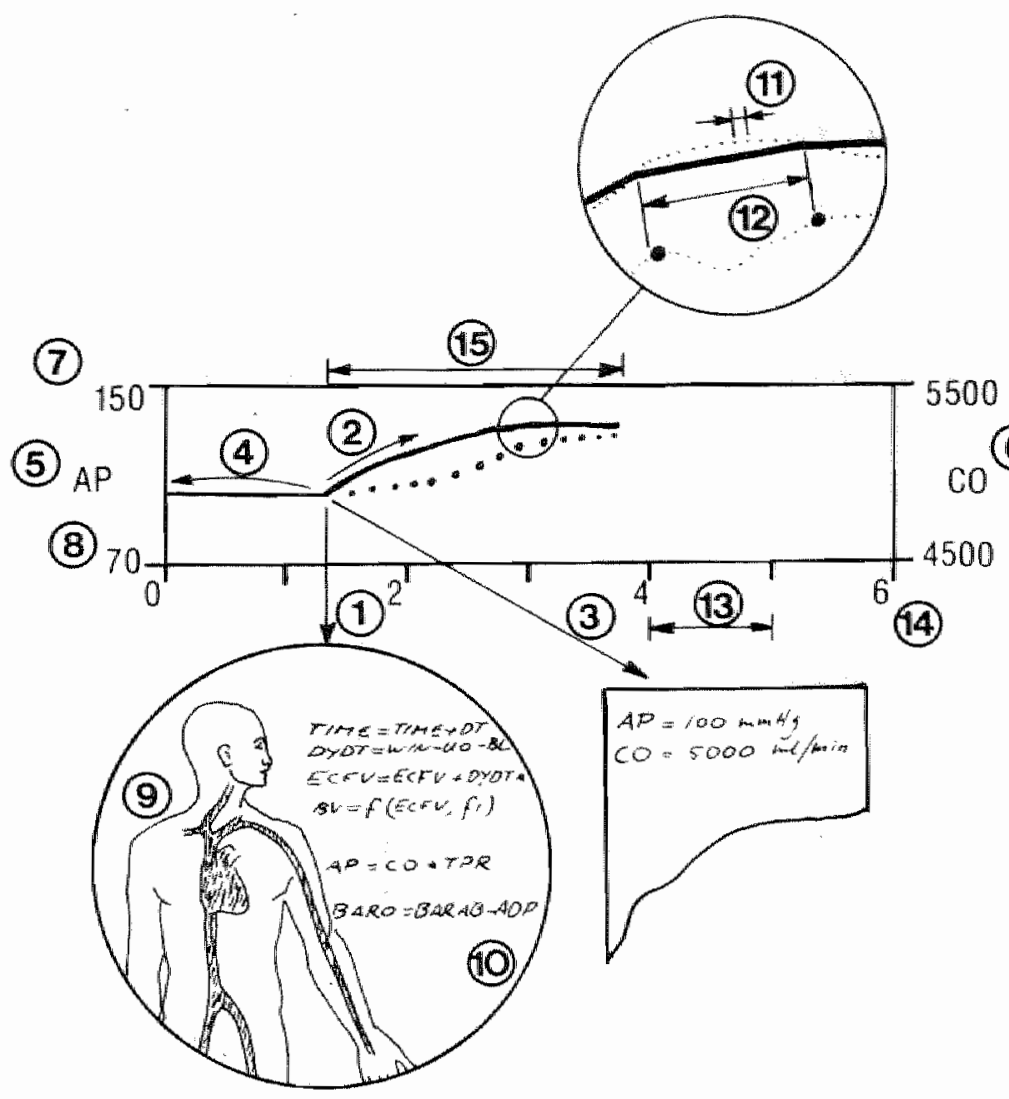

Figuur 2.5.: Enkele begrippen bij de computersimulatieprogramma's.

1. Iets "weranderen" aan b.v. een modelparameter.

2. "Doorgaan" met de simulatie, het meten en registreren van variabelen.

3. "Inspecteren" van de warden van modelgrootheden.

4. "Herstarten" van de simulatile of corrigeren.

5. Naam van de afgebeelde variabele, linkg, behoort bij de getrokken graflek.

6. Naam van de afgebeelde variabele, rechts, behoott bij de gestippende grafiek.

7. Maximumwarde die de variabele kan aanemen bij deze schaalindeling.

8. Minimumarde die de variabele kan aannemen bij deze schaalindeling.

9. De proefpersoon (conceptueel mode1...).

10. Het model in de FORTRAN notatievorm.

11. Integratiestapgronte.

12. Grafische stapgrootre.

13. Assenstapgrootte.

14. Maximale simulatietijd

15. Instelbare looptifd van de simulatie. 
De cursor watht in een vakje, van één karakter breed, tot er een cljfer $(1 \mathrm{t} / \mathrm{m} 8)$ wordt ingevuld van het grafieknumer was lets moet veranderen en springt dan naar het onderste vakje van een karakter breed tot er een cljfer $(0 \mathrm{t} / \mathrm{m} 5)$, naar keuze, wordt ingevuld. In het geval de student kiest woor het veranderen van een te registreren variabele typt hif de naam in op de plaats waar de cursor naar toe gesprongen is warna het minlmum en het maximum voor de $y$-as nog dient te worden ingevuld. Is dit klaar, dan dent de student 0 te typen om naar een andere pagina te kunnen gaan. Alle keuze momenten zijn eenduldig vastgelegd, elk niet bestand commando wordt ingedeeld in categorleën en wordt $\mathrm{d} \cdot \mathrm{m} \cdot \mathrm{v}$. een "foutboodschap" op de onderste paginaregel medegedeeld. Er zijn verscheldene typen fautboodschappen. Als de student nlets meer wil veranderen verschijnt de inhoudspagina weer op het beeldscherm.

\section{Het progranma INSPECT}

Dit programma wordt aangeroepen als de student naukenrig bepalde variabelen wil meten en kunnen aflezen in meerdere decimalen achter de koma (er is gekozen voor de wetenschappelijke notatiewijze $m \cdot m E-n$ indien het getal kleiner is dan 0.000001). Hoewel in de grafleken de 8 varlabelen door een goed gekozen schalindeling goed zijn af te lezen is het belangrtjk on op bepalde momenten de exacte waarde van een vartabele te weten. Dit gebeurt met mode 3.1. Naast deze maximaal 8 variabelen zoals tie in de grafieken worden getekend wil de student ook warden wan andere modelvariabelen kunnen bepalen. Met mode 3.2 kan de student alle modelgrootheden aflezen op het scherm met nam en de warde die deze heeft op het moment van de inspectie. Een derde Inspectiemode (3.3) geeft en overzicht van vijf belangrijke progranmagrootheden zoals de lngestelde tijden voor de maximale simulatietijd, de integratiegroote, de grafische stapgrootte, de assenstapgrootre en de looptijd (zie voor de betekenis van deze tijden flguur 2.5). Ten slotte is er nog een inspectiemode (3.4) die de naam en de warde op het scherm en een aanduiding als een warde meer dan een bepadd in te stellen percentage van de normale warde af wijkt. 
Eunctie van filles in het systeem

Datafile met simulatiedata (RL.DAT)

De files die in het simulatiesysteem voorkomen $z$ ifn ten eerste de datafile RL.DAT met de simulatiedata, warbif onderscheid gemakt dient te worden tussen modelgrootheden (zaals variabelen en constanten) en programmagrootheden (zoals schaalinstellingen en tijden). Deze file RL. DAT ("unformated", 'direct access') fungeert als een communicatefile tussen de programma's START, VERAND, DOOR en INSPEC.

\section{Tekstfile (RL.TEXT)}

Alle programmateksten en modelafhankelijke teksten staan in de tekstfile RL.TXT. Deze file kan met een tekstverwerkend programma ("editor") worden samengesteld en gewijzigd. In deze file stakt tekst van complete beeldschermpagina's of delen daarvan. Door de programma's START, DOOR, VERAND en INSPEC $z$ ijn deze teksten op recordnummer met de subroutine LEES op te roepen en op het beeldscherm te zetten. Deze file, met eenvoudig te veranderen teksten, makt het lastige gebruik van tekst in een FORTRAN progtamma overbodig.

\section{Startwaardenfile (RESTAR.DAT)}

Alle startwaarden van de modelvarlabelen en modelconstanten staan met naam en een unlek (volgorde)numer per record in de startwardenfile RESTAR.DAT. Deze $\mathrm{f} 11 \mathrm{e}$ is ook met een tekstverwerkend programma (editor) samen te stellen en te wijzigen. Hierbij dient wel het formaat van een record intakt te blifven (volgordenumer: 3 ciffers; naam: 4 karakters; warde: 17 digits). In deze file bevindt zlch ook de informatie over de variabelen en de daarbij behorende schalinstellingen, welke normall op het grafische beeldscherm worden getekend (de 8 "default" variabelen).

\section{(Patiënten) casus I1 IIES (CASUS1.DAT t/m CASUS6.DAT)}

De casusfiles CASUS1.DAT t/m CASUS6. DAT zijn in opbouw identiek aam de startwaardenflie RESTAR.DAT, echter met dat verschil dat enkele modelconstanten afwijkende warden hebben. In somalge gevallen heb- 
ben de variabelen nlet de warden van een normale (proef)persoon, mar warden die zijn bepaald ult (steady state) studies met opzettelifk alangebrachte verstoringen.

\section{ResultatenfIIE (RESULI.TXT)}

Elke mutatle die een student in een model aanbrengt tijdens het gebruik van een computersimulatieprograma wordt geregistreerd in de resultatenfile RESULT.TXT. Deze file bevat informatie over de aangebrachte interventies, de datum en de nam van de student. 
Abrahamson, S., P. Wallace;

Using computer-controlled interactive manikins in medical education.

Medical Teacher 2,25 (1980).

AhI, D.H.;

Computers in language arts. Computers in Education, (o. Lecarne and

R. Lewis, eds.), Morth Holland Publ. Co. (1975).

Ahmed, K., D. Ingram, C.J. Dickinson;

Software for educational computing. M.T.P. Press Limited, Lancaster, England (1980).

Alpert, D., D.L. Bitzer;

Advances in computer-based education. Science 167, 1582 (1970). Ariew, R..;

A diagnostic test for students entering a computer-assisted learning curriculum in French. Comp.\& Educ. 3, 331 (1979).

Barker, P.;

The computer as an audio-visual resource. Comp. \& Educ. 3, 23 (1979). Beech, G. ;

Numerical and graphical simulations of chemical processes " Comp. Educ. 2, 9 (1978).

Beek, J.H.G.M. van, M. Woerlee;

Een vemieuwing van A.C. Guyton's model van de bloeddrukregulatie.

(Een nieuw autoregulatiesysteem en een plan tot inbouwen van temperatuurinvloeden). Vakgroep Theoretische Biologie, Rijksuniversiteit Utrecht, Utrecht $(1978)$.

Bergen, S.S. Jr.;

The computer as a tool in medical instruction. J.Med.Soc. 70, 327 $(1973)$.

Bekey, G.A.;

Models and reality: some reflections on the art and science of simulation. Simulation 29,161 (1977).

Benham, R.D., G.R. Taylor;

Interactive simulation language for hybrid computers. Simulation 28 , $49(1977)$.

Bitzer, M.D., D.L. Bitzer;

Teaching nursing by computer: An evaluative study. Comp - Bial.Med. 3. 187 (1973).

Bloch, R., D. Ingram, G.D. Sweeney, K. Ahmed, C.J. Dickinson;

MACDOPE: A simulation of drug disposition in the human body. Mathema-

tical Considerations. J. Theor.Biol, $86,211(1980)$.

Boersma, S.K.T., T. Hoenderkamp;

Simulatie: een moderne methode vam onderzoek. Uitg. Academic Service. Den Haag (1981).

Bouley, J.B.H. de. J.A.M. Howe;

Logo building blocks. Student teachers using computer-baged mathematics apparates. Comp. Educ. 6, 93 (1981).

Bramer, M.;

Using computers in distance education: The first ten years of the

British Open University. Comp \& Educ. 4, 293 (1980).

Brigham, C.R., M. Kamp;

Introduction to special issue on Computer-Assisted Instruction in the

Health Sciences. Comput.Biol. Med. 3, 183 (1973).

Bronson, $\mathbb{R}$.;

Teaching simulation in industrial and academic setting. Simulation

30, $203(1978)$. 
Bryant, T., J.E. Smith;

A teaching exercise for the identification of bacterial using an

interactive computer program. J.Biol. Educ. 13, 58 (1979).

CAL 77;

Symposium on Computer Assisted Leaming. Delegate information and abstracts, University of Surrey, Guildford, Surrey (1977). (Secretary: K.R. Knight).

CAL 79 ;

Symposium on Computer Assisted Learning. Delegate information and abstracts, University of Exeter, Exeter U.K. (1979). Secretary: J.J. Mat thews).

CAL 81 ;

Sympositum on Computer Assisted Learning. Delegate information and abstracts. University of Leeds, Leeds U.K. (1981). (Secretary:

J. H. Hartley).

CAL 81;

Computer Asgisted Learning. Selected papers from the CAL 81 Symposium.

Pergamon Press Ltd. Oxford. ook in: Comp.\& Educ. 6 (1981).

Camstra, B.;

Project plan, 2e dee1. Plato proefproject Amsterdam. Uitgave cowo

Centrum voor onderzoek van Wetenschappelijk onderwijs. Universiteit

van Amsterdam, interne uitgave (1978a).

Camstra, B.;

Miet wie mar wat is Plato? Onderzoek van Onderwijs I, 13 (1978b).

Camstra, B., C. Schagen, J.J. Hox;

Leren met de Computer. Voortgangsverslag no. 3, cowo, Universiteit van Amsterdam, intertue uitgawe (1978).

Camstra, B., T. van Dijk, W. v.d. Avoird;

Leren met de Computer, Eindrapport van het Platomproefproject, cowo, Universiteit van Amsterdam, inteme uitgave (1979).

Camstra, B.;

Leren en anderwijzen met de computer. Stenfert Kroese B.V., Leiden (1980).

Carson, R.E., C. Cobelli, L. Finkelstein;

Modeling and identifucation of metabolic systems. Amer.J.Physiol. $240, R 120(1981)$.

Cassano, W. F.;

A biochemical simulation system. Comp.Biomed. Res. 10, 383 (1977).

Coleman, T.G*;

The concept of gain in biological system. Dept. of Physiology and Biophysics, Univ. of Mississippi, Jackson, internal paper (1977a).

Coleman, I.G., C. Hillary, H.C. Mesick, R.L. Darby;

Numerical integration. A method tor improving solution stability in models of the circulation. Ann.Biomed. Eng. 5, 322 (1977).

Coleman, T. G. ;

Simulation of biological systems. Dept. of Physiology and Biophysics,

Univ, of Mississippi, Jackson, Internal paper (1977b).

Coleman, T.G. (ed.);

Computer imulation of physiological systems: a review. Simulation 46, i. (1978).

Coleman, T.G., H.C. Mesick;

Twenty (mostly physhological) problems that can be solved using a computer and basic programing language. Dept. of Physiology and Biophysics, Univ. ol Mississippi, Jackson, internal paper (1978). Coleman, T.G., R. Darby;

SIM2, fortran programs for simulation of continuous systems. Dept. of Physiology and Biophysics, Univ, of Mississippi, Jackson, internal paper $(1979)$. (idem SIMI: 1979b). 
Coleman, T.G., G.G. Jaros:

User manual, SIM2, fortran programs for simulation of continuous systems. Dept. of Fhysiology and Biophysics. Univ. of Mississippi, Jackson, intemal paper (1979). (idem SLMI: 1979d).

Graenen, G.;

Over responsetijden: niet afwachten mat jużst vooruit zien. Computable 10 juli 1981 .

Crombach, H.F.M., T.M. Chang, K.D.J.M. van der Drift, J.M. Moonen; Onderwijsmiddelen van de open Universiteit: functies en kosten. Advies aan de Commissie Voorbereiding open universiteit door het bureau Onderzoek van Onderwijs van de RuL, Leiden (1979).

Demaid, A., P.G. Butcher, J. Verrier;

Understanding phase diagrams - an example of the incegration of interactive graphics into a CAL authoring system. Comp. \& Educ. 6, 133 (1981).

Diana, I.P.F. de, T.J.H.M. Eggen, R. Steen;

Computerfaciliteiten voor toegepaste onderwijskunde; achtergronden en specificatie. Afdeling der Toegepaste anderwijskunde; Technische Hogeschool Twente, Enschede (intern rapport) (1981).

Diana, I.P.F. de, L.R.C. de Zwart;

Computer ondersteund onderwijs. Vooruitzichten op toepassingen in het wetenschappelijk onderwijs. Onderwijskundig Centrum Bulletin, T.H.

Twente $(1982)$.

Dickinson, C.J., D. Ingram, K. Ahmed;

A review of educational applications of a series of four models of circulation, respiration, body fuids and electrolytes and drug. absorption and distribution. In: Lecture Notes in Medical Informatics

(Eds. B. Barber, F. Gremy, K. Uberla, G. Wagner), Springer Verlag, Berlin, 471 (1979).

Di.ckinson, C.J., D. Ingram, K. Ahmed;

Introduction guide to the MAC family of physiological models and to

the Barts/McMaster Medical education software. Medical College

St. Bartholomeus Hospital, London, Hingland, internal paper (1981).

Dirkzwager, A., J.J. Beishuizen, G.F. Bernarty, E.J. Kok, L. de Leeuw,

D.C. Ottevangers, F. Pijpers-Drenth, G.C. v.d. Veer;

Computers en onderwijs: de tweede IFIP wereldconferentie. Informate $18,69(1976)$.

Dijk, T.A.M., W. v.d. Avoird;

Learning with a computer: Some preliminary results of the PLATO project

at the university of Ansterdam. Paper presented at CaL 79 conference, Exeter (1979).

Drift, K.D.J.M. van der:

De computer in het onderwijs: Weel geprezen max zelden geprijsd.

Bureau Onderzoek van Onderwijs, Ru, Leiden (1978) (ongepubliceerd).

Dxift, K. Wan der, W.F. Langerak, J.M. Moonen, P. Vos;

Eindrapport van het proefproject computergestuurd onderwijis. Bureau

Onderzoek vam Onderwijs, RuL, Leiden (1980).

Driscoll, J.;

A study of an application of computer aided leaming to business

simulation. Comp. \& Bduc. $6,127(1981)$.

Elmqu ist, H.;

Manipulation of continuous models based on equations to assignment

statements. Dept. of Autonomic Control Lund Institute of Techn.,

Lund, Zweden (1979).

Every, T.M. "

Graphics and animations in teaching dialogues. Paper prepared for

CAL 81 (1981). 
Faddegon, J., R. Maathuis, A. Vrins:

Aanbevelingen van het ontwerp van mens-machine dialogen. Intormatie $7 / 8,422(1981)$

Darveau, R.R.;

Computer graphics in simulation. Simulation $32,34(1979)$.

Fintz, J., K. Glanzer, H.E. Renschler, G. Voss;

Computer-Unteretutzer-Unterricht in der medizinischen Ausbildung.

Reisebericht, Institut für Didaktik der Medizin der Universitä

Bonn, Bonin (1976).

Eor, J., M. Rushby;

Cuidelines for developing educational computer programs. Comp. \&

Educ. 3, 35 (1979).

Friedman, R.B.;

A computer program for simulating the patient-physician encounter.

J.Med.Educ. 48,92 (1973).

Gann, D.S., G.J. Cryer, J.D. Schoeffler;

Finite level model of biological systems. Ann. Bioned.Eng. 1, 385 (1973).

Garbutt, K., P.J. Murplyy, A. Vardy;

A cal-based undergraduate genetics course. Comp. E Educ. 3, 353 $(1979)$.

Garfinkel, D., C.B. Marbach, N.Z. Shapiro;

Stiff tifferential equations. Ann. Rev. Biophys. Bioteng. 6, 525 (1977). Gartinke1, D.:

Applicability of structured programing to medical computing. Comput. Biomed. Res. 11. 1 (1978).

Gastkemper, F.H.D., M.D. Lejblum, A.T.M. Horsten, K.G. Derks;

Projectverslag CAI, achtergrond, ervaringen, voorstel, ontwikkelingen.

Instituut voor Onderzoek van bet Wetenschappelijk Onderwijs, Katholieke

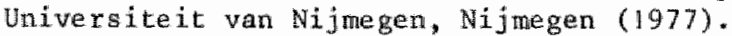

Gastkemper, F.H.D., E.J.M.M. van Hees, C.A.P.G. van der Mast (redaktie); (Ca) Voorzieningen voor computerondersteuning van het tertiair onderwijs.

Vereniging woor Onderwijs en Computer, Tilburg (1979).

Gastkemper, F.H.D. (redaktie);

Computer Assisted Instruction (CAI) en video langspeelplat (VLP);

Symposium verslag; Voc-publicatiereeks (81/02), Vereniging woor

Onderwijs en Computer, Utrecht (1981).

Guyton, A.C., T.G. Coleman, H.J. Granger;

Circulation: overa1] regulation. Ann. Rev.Plyysiol. 34, 13 (1972).

Harless, W.G., C.G. Drennon, J.J. Marxer, J.A. Root, G.E. Miller;

CASE: A computermaded simulation of the clinical encounter. J.Med.

Educ. $46,443(1971)$.

Hawkins, C.A.;

The performance and the promise of evaluation in computer based

learning* Comp. E Educ, 3, 273 (1979).

Hebenstreit, J.;

Micro-computers in secondary education. In: Micracomputers in

secondary education (Eds. E. D. Tagg), 3e IFIP Working Conf. on

microcomputers in secondary education. North Holland Publ. Comp.

Ainsterdan (1980).

Hees, E.J.W.M. van:

Voorgieningen voor CAI. Intermediair 16 , no.25 (1980a).

Hees, F.J.W. M. want;

De computer als onderwijsmiddel. Intermediair 16, no.27 (1980b).

Hees, E.J.W.M. van;

(Ca)

Computerondersteuning in totalbeell. Intermediair 16, no.27 (1980c). 
Hees, E.W.J.M. van;

Computer Managed Instruction (CMI): een breder perspectief en een

implementatie. 1 . Informatie $23,24(1981)$; 2 . Informatie 23,86

(1981).

Hees, E.J.W.M. van; EDUSERVICE-A computer assisted evaluation system. Comp. \&duc. 6,311
(1982).

He lsgaun, K. ;

Disco: a SIMULA based continuous combined and discrete simulation. Simulation 35, 1 (1980).

Hinton, $\mathrm{T}$;

Computer assisted learning in plrysics. Comp. \& Educ. 2. 71 (1978). Hoffer; E.P.;

Experience with the use of computer simulation models in medical education. Comput. Biol.Med. 3, 269 (1973).

Hoffman, K.I., S. Abrahamson;

The cost effectiveness of SIM-ONE. J.Med. Educ. 50, 1127 (1975).

Hooper, R.;

Computers in science teaching - an introduction. Comp. Educ. 2,1 $(1978)$.

Hul, F. van " $t$ :

Computergebruik in het onderwijs. In: Vroeijenst ${ }^{\prime j}$, A. en Woerden $W$. wan (redaktie). Congresboek $3 e$ National Congres: Onderzoek van Wetenschappelijk Onderwijs (I). Delftse Univ. Pers, Delft (1976).

Hijden, P. van der;

The method of interactive simulation. Proceedings of UKSC Conference on Computer Simulation, Chester, U.K. (1978).

Iberall, A.S.;

On nature man, and society: A basis for scientific modeling. Ann.

Biomed. Eng. 3, 344 (1975).

Index to Computer Based Learning (Ed. C. Wang);

Instructional Media Laboratory, University of Wisconsin Milwankee (microfiche) (1978).

Ingram, D., C.J. Dickinson, K. Ahmed;

The design of Software for Computer-Assisted instruction, interview

and assessment. In: Lecture Notes in Medical Informatics (eds. B. Barber,

F. Cremy, K. Uberla, G. Wagner). Springer-Verlag, Berlin, 51 (1979).

Jennrich, R.I., M.L. Ralston;

Fitting nonlinear models to data An. Rev. Bioeng. 8, 195 (1979).

Johnson, D.C., G.0. Barnet:

MEDINFO - A medical information system. Comput. Progr.Biomed. I, 191 (1977).

Kane, D., B. Sherwood;

A computer based course in classical mechanics. Corip. \& Educ. 4, 15 $(1980)$.

Katz, F.M., T. Fülö (Eds.);

Personnel for health care: case stories of educational programmes.

Public Health Paper 70 (I), World Health Organization, Geneva $(1978-1980)$;

Kerbosch, J.A.G.M., R.W. Sierenberg;

Discrete simulatie met behulp van ALGL, FORTRAN, PL/1 uitgeveriff

Samson, Alphen aan de Rijn (1973).

Klabbers, J.H.C., P.P. van de Hijden, K. Hoefnagels, G.J. Truin; Development of an interactive simulation/gane: a case study of the

development of DENTIST (DENTal health care interactive simulation too1). Praceedings of the 10th ISAGA conference; augustus 1979, Leeuwarden, (Eds. K. Bruin et al.) Rijksuniversiteit Groningen, Groningen (1979). 
Koolnat. A. ;

Toepasing interactief instructie systeem (IS) in het informatica

onderwijs. Informatie 22,772 (1980).

LaL, S., A. W. Wood:

Computer-assisted learning in the teaching of physialogy. J.Physiol.

270, $\mathbb{1}$ ip $(1977)$.

Laurillard, D.;

Evaluat on of student learning in CAL. Comp. Educ. 2, 259 (1978).

Läzär, $G_{m}$

Trends of education in computer techniques. Comp. E Educ. 3, 127

$(1979)$.

Lecarne, O., R. Lewils (Eds.).

Computers in education. Praceedings of the IFIP 2nd World Conference.

North Holland Publ. Comp., Amsterdam (1975).

Leiblum, M.D.;

Screening and scheming for CAL. Comp. Educ. 3, 313 (1979).

Lewis, R., E.D. Tagg (Eds.);

Working Conference Van IF IP TC3 Education in Rochampton, England,

september 1979, North Holland Publ. Comp., Ansterdam (1979).

Lewis, R., J. Harris;

Physics education with or without computers. Comp. \& Educ. 4, I1 (1980).

Mackey; M.C., L. G1.as:

Oscillation and chaos in physiological control systems. Science 197 ,

$287(1977)$.

Madsen, B.W., R.C. Bell;

The dlevelopment of a computer assisted instruction and assessment

system in pharmacology. Medical Education 11, 13 (1977).

Marrow, $\mathbb{F}, \mathbb{R}$. Hooper, K. Knight;

Computer assisted training programme. Working Document 1 ; Mills

\& Allen Communications Ltd., London (internal paper) (1979).

Mast, C.A.P.G. van der:

Leren per computer. Intermediair 14, no. 28 (1978)

Mast, C. v.d. (Ed.);

Onderwijs en microcomputers, voc-publicatiereeks $(80 / 02)$, Vereniging

woor Onderwijs en Computer, Utrecht (1980).

Mckenzie, J.;

Interactive computer graphics for undergraduate science teaching.

Comp. Educ. 2. 25 (1978).

Mckentie, J., L. ElEon, R. Lewis (Eds. );

Interactive computer graphics in science teaching. Ellis Horwood

Limited, Chichester, Sussex, England (1978).

Meertanan, J.W.;

THISM, software for the simulation of continuous dynamic system on

small and very small. computer systems . Paper presented at the

simulation 1980 conference; Interlaken-Schweiz (1980).

Meijer, D.K.F., P.G. Ruifrok;

Gurvefitting - in - imlatie in de farmacokinetiek. MacDope en andere

computexprogx mat ' Pharmaceutisch Weekblad 117, 625 (1982).

Merrill, M.D.;

luarner control in computer based learning . Comp. \& Educ. 4,77

$(1980)$.

Min, F.B.M., K.M. Ephrä̈ri

Computer assisted instruction voor het leren overzien van de

ananirese. Proceedings Medisch Informatica Congres "79, Antwerpen

(J.L. Willems, redaktie) (1979).

Min, F.B.M., H.A.J. Struyker Boudier;

Computer simelation in problem oriented medical learning. Proceedings;

International Simulation and Gaming Association Conference,

Leevwarden, II, 186 (Ed. K. Bruin) (1979). 
Miitche11, P.D.;

Can CAL link the theory and practice of instraction. Comp. \& Educ. 3 , 295 (1979).

Moonen, J.;

Organisatie van statistiekonderwijs in het eerste jaar van de

psychologie-opleiding. Congresboek, 3e National. Congres: Onderzoek van Wetenschappelijk Onderwijs, Delft (I en II) (Red. A. Vroeijenstein en W. van Woerden) (1976).

Moonen, $J_{*}:$

Computergestuurd onderwijs; mogelijkheden en beperkingen. Rupport sub-

fac. Psychologie, Rijksuniversiteit Leiden (1979).

Moonen, J. (Redactie);

Computergestuurd Onderwijs in het tertiaire onderwijs. voc-publicatiereeks $(80 / 04)$, Vereniging van Onderwijs en Computer, Utrecht (1981).

More 1, L. ;

Some experiments of using CAL in secondary education. Papex presented at CAL 79 conference, Exeter, U.K. (1979).

Neale, S.G.;

The development and use of a mapping package for sixth form geography students. Comp. Educ. 3, 367 (1979).

Neufeld, V.R., H.S. Barrows

The McMaster Philosophy: An approach to medical education. J.Med.Educ. 49. $1040(1974)$.

Nieverge 1t, J.;

A pragmatic introduction to courseware design. Computer 13, 7 (1980).

Oomen, P.M.F., M. Woerlee;

Een systeen-theoretische analyse van de bloeddrukregeling bij de

mens. Ned. Inst. voor Preventieve Geneeskunde/TNo, Leiden (juni. 1975).

Oren, T.I.;

Software for simulation of combined continuous and discrece systems:

a state-of-the-art-review. Simulation 28,33 (1977).

Paden, D.W., M.D. Barr;

(cb)

Computer-assisted instruction in an elementary college economics

course. Comp. \& Educ. 4, 259 (1980).

Palm, G. ;

on representation and approximation of nonlinear systems. Biol.

Cybernetics $31,119(1978)$.

papert, S.;

Mindstorms: Children, computers and powerfull ideas. Basic Books, Inc.,

Publishers, New York (1980).

Partridge, L.D.:

Simulation in bionedical teaching. I.E.E.E.-T.B.E., , 78 (1972).

Pearson, Pi.;

A case study of the computational physics teaching laboratory. CPIL

project. Council for educational technology for the United Kingdon

(niet gepubliceerd) $(1977)$.

Pinxteren, H., E. Hoenkamp, J. Ringelberg, H. Sipman;

Het LOGO-project Nijmegen, achtergronden en witgangspunten. Vakgroep

Sociale Psychologie, Kath. Universiteit Nijmegen, Intern rapport,

Nijmegen (1982).

Plant, R.E.;

The efficient numerical solution of biological simulation problems.

Comput.Progr.Biomed. 10, 1 (1979).

Pratt, F.L., O.E. Pratt;

A new method for running computer models of physiological systems

J.Physiol. 281, 5P (1978). 
Rahenlow, H.F.;

Business and industrial applications of computer-based training. Paper presented at CAL 79, Exeter, U.K. (1979).

Randa11, J.E.;

Microcomputers and physiological simulation. Addison-Wesley Publishing Company, Massachusetts (1980).

Roman, G.C., D. Garfinkel;

BIOSSIM - A structural machine - Independent biological simulation

language. Comput. Biomed. Res. 11, 3 (1978).

Ruigt, G.S.F., M. Woerlee;

Een model van de regeling en de dymamica yan de vochtopname bij de mens. Aanpasing van de vochtbalansregeling van een computermodel van de bloedcirculatie. Mathematische Biologie, Rijksuniversiteit utrecht, Utrecht, (bijvakvetslag) (1978).

Rushby, N.J.;

Finding out about CBL. Computers in Schools 2, 10 (1980a).

Rushby, Nid.;

The cedar project. CEDAR project, Imperial College, London (1980b). Rustiby, N.J.;

Gettung started with computing based learning. Visual Education 8 , $8(1980 \mathrm{c})$.

Rushby, N.J.;

FOCT for computer based leaming in the United Kingdom. CEDAR project, Imperial College, London (1980d).

Sagawa, K..;

Concerning "gain". J.Am.Physiol. 234, H117 (1978).

Saunders, L., D. Ingram, C.J. Dickinson, M. Sherriff;

A comprehensive computer simulation of drug metabolism and kinetics.

Comp. \& Educ. 6, 243 (1982).

Schmidt, H.G., P. A.J, Bouhuys;

het tutorensysteem. Capaciteitsgroep onderwijsontwikkeling en

Onderwijisresearch, RL, Maastricht (2e druk) (1977).

Schmidt, H. G.;

Probleem georiënteerd onderwijs: leren aan de hand van problemen.

Metamedica $57,4(1978)$.

Schnidt, H.G., P.A.J. Bouhuys;

Onderwijs in takgerichte groepen. Het Spectrum B. W., Utreche (1980).

Sthraidt, H. $\mathrm{G}$,

Problem-based learning: Rationale and description; Onderzoek van

onderwijs, 13, (Red. J.J. Beliën at al.), Capaciteitsgroep Onderwijsontwikkeling en Onderwijsresearch, RL, Mastricht (1982a).

Schmidt, H.G. $(\operatorname{Red} *)$;

Brobleen-gestuurd onderwijs. Bijdrage tot de onderwijsresearchdagen

1981; Stichting voor Onderzoek wan het Onderwijs; Svo-reeks; Flevodruk, Harlingen B.V. (1982b).

Schneider, B., U Rante (Eds.):

Simulationsmethoden in der Medizin und Biologie "Workshop, Mannover 1977. Springer Verlag, Berlun-Heidelberg (1978).

Smith, Y.C.H.;

The PET 200 and CAL: its use in the physiology laboratory. Comp. \& Educ. 3, $361(1979)$.

Starkweather, J.A.;

Computest: A computer language for individual testing, instruction, and interviews. Physiological Reports 17, 227 (1965).

Struyker Boudier, H.A.J., F.B.M. Min;

Computer simulation of the cardiovascular system: a research tool for study of the pathogenesis and therapy of high blood pressure.

proceedings: Intern. Simulation and Gaming Ass. Conf. Leeuwarden I, 321-338 (ed. K. Bruin) (augustus 1979). 
Sparkes, C.A.:

A CAL package case study: from idea to package. Paper presented a CAL 1979 conference, Exeter (1979).

Sundaram, K., S. Srinivasan;

Computer simulated modelling of biomolecular systems. Computer programs

in Biomedicine 10,29 (1979).

Tagg, E. D.;

Microcomputers in secondary education. IFIP TC3 Working Conference on

microcomputers in secondary education. North-Holland Pub1. Comp.

Amsterdam (1980).

Tagg, E.D., R. Lewis (Eds.);

Computers in Education. 3rd World Conference on computer education

(WCCE 81), North Holland Publ. Comp., Amsterdam (1981).

Tavernini, L.;

The automatic sequencing of block-operators in the digital sinulation

of analog and analog hybrid computers; I.E.E.E.-T.E.C. , 963 (1965).

Teach, R.L., E.H. Shortlife;

An analysis of physician attitudes regarding computer-based clinical.

consultation systems. Comput. Biomed. Res. 14, 542 (1981).

Teleac;

Wiskundige modellen; cursusboek behorende bij de Teleac cursus

Wiskundige Modellen; Stichting Teleac, Utrecht (1981) (J.v.d.Boogert, coördinator).

Tennyson, R.D.;

II. Applications of computers in education. Physiologist 16,600 $(1973)$.

Thies, R..E.;

$\mathrm{An}$ experiment comparing computer-assisted instruction with lecture

presentation in physiology. J.Med.Educ. 44, 1156 (1969).

Ti.dball, C.S.;

Operating systems and computer languages for educational applications.

Physiologist 16, 617 (1973).

Tiddens, H.A., Willighagen, R.G.J., Wijnen, W.H.F.W.;

Medisch onderwijs in ontwikkeling, studiejaar 1974-1975. MFM; Medisch

Contact 30, 1077 (1975).

Timmermans, $A$., E. wan Hees;

Computer Ondersteund Onderwijs (COO) in Nederland 1980/1981. Onder-

wijs Research Centrun, Katholieke Hogeschool Tilburg, Tilburg (1981)

(niet gepubliceerd).

Tromp, H.W.;

Political attitudes and political behaviour in international crisis

- a simulation study of discision. Proceedings ISAGA conference

(1979), Leeuwarden (Ed. K. Bruin et a1.).

Trzebiatowski, G.L., I.G. Ferguson;

Computer technology in medical education. Med.Progr. Technol. 178,

186 (1973).

Verveen, A.A.;

Modelbegrip in de wetenschap. Intermediair, 7 juli 1972.

Verveen, A.A.;

Wanneer oscilleert een regelsysteem en wanneer niet? Voordracht

Oscillatiedag, sectie bioregulaties. Ned. Ver. woor Theoretische

Biologie (sept.1980). (niet gepubliceerd).

Weidenhammer, J., W. Hofmeister, U. Kremer;

Computerunterstüzung der medizinischen Ausbildung. Literaturauswer-

tung, Int. für Didaktiek der Medizin der Rheinischen-Friedrich-Withelms-

Universitat, Bonn (1976). 
Wijuen, W. H.W. W. :

Evaluatie van een medische opleiding. Wit: Onderwijskundige Studies, Aspecten van Leerplanevaluatie (Red. P. Heerda), Malmberg B.V., Den Bosch $(1981)$.

Witte, P.C.F., de

A software package for computer managed instruction. Comp. \& Educ. 4 , $325(1979)$.

Worster, H., J.F. Lewis;

Digtribution of computer assisted instrumental materials in biomedicine through the Lister Hill Center Experimental Network. Comput.Biol. Med. 3, $319(1973)$.

Yamamoto, W.S., E.S. Walton;

On the evolution of the physiological model. Ann "Reviews Biophys.

Bioeng. 4, 81 (1975),

Yates, F.E.;

Comperat ive physiology: compared to what? Am.J.Physiol. 6, R1 (1979).

Yates, F.E.;

Good manners in good modelling: mathematical models and computer

simulation of physiological systems. Am. Physiol.Soc. 3, 159 (1978). Zeigler, B..P.;

Theory of modelling and simulation. John Willey \& Sons Inc., New York $(1976)$,

1) Categorieèn:

Ca CAI algemeen

Cb CAI op ëén bljzonder vakgebied

$M$ Modelvorming en modelvormingtheorle

Sa Simulatie algemeen

Sm Simulatie en biomedische modellen

St Simulatietalen en systemen

0 Onderwitis 
HOOFDSTUR 3

Computersimulatieprogramma AORTA

Onderwijisdoel

Studenten kunnen in de beginfase van hun studie met het computersimulatieprograma AORTA kennis maken met enkelle basale begrippen uil de hemodynanica. Bij het gebruik van dit programa wordt antwoord gegeven op vragen als "Wat gebeurt ex als de compliantie van de aorta vermindert?" of "Wat gebeurt er als de totale perifere weerstand van de circulatie wordt verhoogd?". Ook het omgekeerde kan een onderwijsdoel zijn, namelijk de wraag wat de oorzaak is van het afwijkende beeld van de diastolische druk in de aorta. "Ran de oorzak van een verlaggde diastolische druk in de aorta een afgenomen compliantie van de aorta $z$ ijn? Ja of nee?" Studenten leren met begrippen als compliantie en totale perifere weerstand, en veranderingen daarin, omgaan. Studenten worden geacht wragen te kumen formuleren en/of hypotheses op te stellen en dere hypotheses te verifiëren m.b.v. dit simulatieprograma. In het kader van een blok over atherosclerase (1.5) is casuistiek ontwikkeld over verkalking van de aortawand en coegenomen totale weerstand van de perifere circulatie. Bij deze casuistiek dienen de studenten zelf te onderkennen dat de gemiddelde perifere stroom is weranderd en moeten ze proberen deze te herstellen door de ventrikeldruk aan te passen. Het programma is bedoeld om met basalle hemodynamische relaties om te leren gaan zoals die tussen druk, compliantie en volume $(\mathrm{CaO}=\mathrm{d}(\mathrm{VaO}) / \mathrm{d}(\mathrm{PaO})$ ) en tussen stroom, weerstand en druk ( $\mathrm{Pp}=$ Pao $/$ Rp) en tevens de gevolgen na te gaan die interventles hebben op hemodynamische variabelen.

Het windiketelmodel

In 1899 introduceerde Frank een model van het hart en de circulatie van het bloed in een menselijk lichaam dat niet zoals in die tijd gebrutkelijk, een statisch model was, maar en model dat het dynamisch gedrag wall de blloeddrukgolf kon simuleren. Dat model, gevuld met water dat dour buizen stroomde bevacte een windketel (c.q. expansievat). Het idec vam een windkecelnodel was al eerder gelanceerd door Hales in 1733, matar Frank concretiseerde dit model en gaf daarbij een verklaring voot 
de gevonden resultaten. Zijn model was tevens een doorbraak nar de dynamische modelworming in de medische wetenschappen. Het mechanisch model met een dergelijke windketel geeft een verklaring voor het feit dat een discontinue instroom, door de bufferwerking van de windketel een conthue ultstroom tot gevolg heeft (zie figuur 3.1) (cf. Westerhof et a1., 1971; Moordergraal en Meester, 1973; Noordergraaf, 1978).

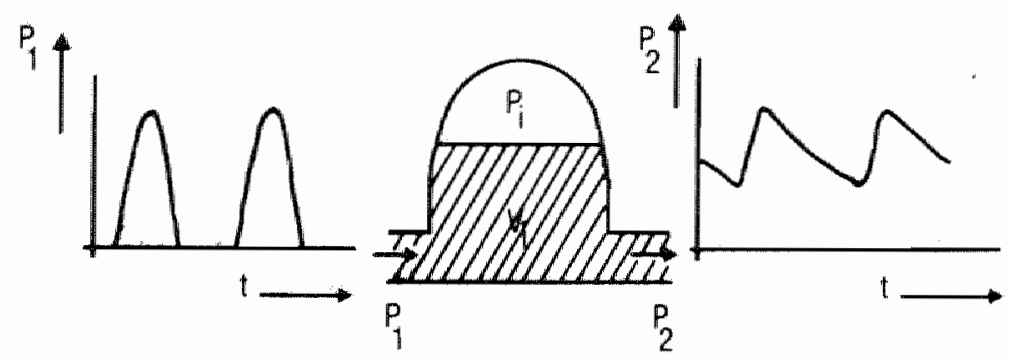

Eiguar 3.1: Het indketelmodel van de aorta. Als de input druk ( $\left.P_{1}\right)$ discontinue verloopt zoals in de figuur is angegeven dan verloopt de output druk $\left(\mathrm{P}_{2}\right)$ zoals in de flgur te zien is veel. gelijkmatiger. Met name her minimum van $\mathrm{P}_{2}$ is veel hoger dan dat van $\mathrm{P}_{1}$

Nar analogie van dit model zijn er later ook electrische modellen gemaakt die verklaringen geven woor dit fenomeen. Zowel het windketelmodel als zijn electrische analogon leggen de basis voor het kunnen opstellen van de wiskundige vergelijking die dit alies kan simuleren. Het vermogen wan het arteriele stelsel om de discontinue ventrikeldruk te reduceren tot een voor de perifere circulatie meer gewenste gelijkmatlge druk wordt verklaard door de compllantie van met name de grotere arterlën zoals de arta (Bernards en Bouman 1979 ). De sterk variërende druk th het hart die oploopt tot carca 120 mmitg en dararna gedurende een halve periode 0 mmig blifft wordt teruggebracht tot een weel gelijkmatiger druk die nog mas warleert wan circa $70 \mathrm{mmHg}$ tot $120 \mathrm{mmHg}$. Dit model is het meest eenwoudige model van de circulatie. Details zijn keggelaten. Zo kan b.w. niet de dicrotische piek in de blaeddruk die ontstat bij het sluiten van de kleppen worden gesimuleerd. De hier beschreven interventies en de gevolgen daarvan zijn met dit model echter goed te simuleren (Coleman, 1977; Arts, 1978; Farrar et a1., 1978; Katz et a1..1978). 


\section{Opbour model}

Bij het model gepresenteerd in dit hoofdstuk worden alle stappen in de modelvorming -van concept tot en met FORTRAN notaliewijze- besproken ler fllustratie. Bij de overige hoofdstukken wordt dit minder uitvoerig gedaan. De circulatie is bij dit model opgedeeld in 3 segmenten (ale figuur 3.2 ).

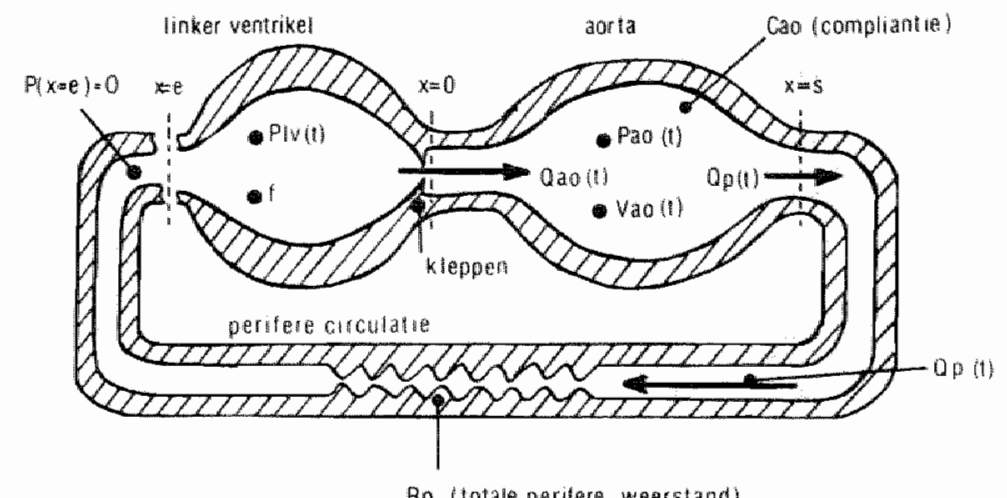

Rp totale peritere weerstand)

Figur 3.2 : Het model van de circulatie bij het computersimulateprogramma AORTA met 3 segmenten: de linker ventrikel, de aorta en de perifere circulatie.

Segment 1 is de linker ventrikel die het bloed discontinu de circulatie inpompt. De linker ventrikel genereert een discontinue drukgolf (Plw) met een slagfrequentie (f) van $1 / \mathrm{sec}$, een diastolische druk van 0 mulg en een systolische druk van maximaal $120 \mathrm{mmHg}$ (Plvmax) volgens:

$$
\begin{aligned}
& \mathrm{PIV}(\mathrm{t})=0 \quad \pi+2 \pi n<\mathrm{ft}<2 \mathrm{n}+2 \mathrm{nn} \\
& \mathrm{Plv}(\mathrm{t})=\text { Plvmax.sin (2mft) } \quad 0+2 \pi n<\mathrm{ft}<\mathrm{\pi}+2 \pi n
\end{aligned}
$$

met $0 \leq n<\infty$ (at figuur 3.3).

Segment 2 is de aorta, wate compltantie van het vatscelsel bij dit model is geconcentreerd. De linker ventrikeldruk is de input voor de aorta. De aorta is echter een elastisch reservolr dat bloed bevat en het bloed uit de linker ventrikel tijdelijk kan opvangen vanwege 21 jn elastische eigenschappen Noordergraf, 1978; Min en Struyker Boudier, 1979; Struyker Boudier en Min, 1979).

De compliantie van een bloedvat, zoals de aorta, heeft de volgendu relatie:

$$
\text { Cao }=\text { MVao(t) / } \Delta P a O(t)
$$

die kan worden omgezet in de integraalvergelljking:

$$
\left.\operatorname{Pao}(t)=\mathbb{\int}(\mathrm{Qao}(\mathrm{t})-\mathrm{Qp}(\mathrm{t})) \mathrm{dt}+\mathrm{Vao}(0)\right] / \mathrm{CaO}
$$


Als we op het scheldingswlak tussen de linker ventrikel en de aorta stellen $x=0$, op het scheldingsvlak tussen aorta en de perifere circuLatie $x=8$ en voor het scheidingsvlak tussen de perifere circulatie en de Inker ventrikel $x=a$ dan hangt het bloedvolume in de aorti af vary de hoevelheld bloed die de aorta per tijdseenheid instroont Qao $(t, x=0)$ minus de hoeveelheid die de arta per tijdsenheid uitstromt Qao $(t, x=5)$ en de hoeveelheid bloed die er op het tijdstip 0 anweztg (Vao(0)). (zie figutr 3.2)

Segment 3 de perifere circulatie. De stroom door de perifere circulatie is $\mathrm{Qp}(t, \mathrm{x}=\mathrm{g})$. Veronderstel dat er geen compliantie in de perifere circulatie is, dan is $Q p(t, x=e)=Q p(t, x=s)$.

Veronderstel dat de druk op het einde van de perifere circulatie $(x=e)$ is $P(t, x w e)=0$ en de druk op $x=s$ is $P a o(t, x=s)$ met: $\operatorname{Pao}(t, x=s)=\operatorname{Pao}(t, x=0)$ dan is $Q p(t)=\operatorname{Pao}(t) / R p$.

De netto bloedstroom de aorta in is een functie van de drukken Pao $(t, x=0)$ en Plv $(t, x=0)$ en is op $x=0$ Qao $(t)=[[P \perp v(t)-P a o(t)]$. Als Plv(t)>Pao(t) dan is Qao(t) $=33.0[P 1 v(t)-P a o(t)]$ en als Plu(t)<Pao(t) dan is $Q$ ao $(t)=0$

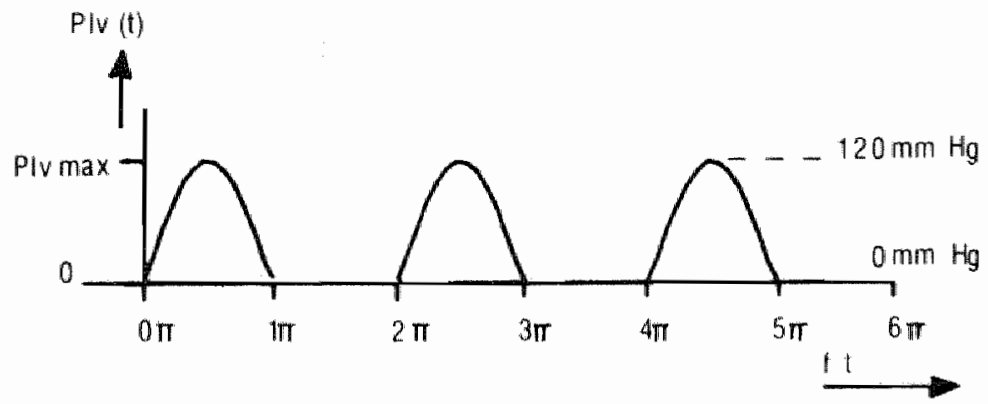

Fijutur 3.3: De linker ventrikeldruk. Deze druk wordt bij dit nodel niet beinvloed van buitenaf. De druk is slechts een functe van de frequentie, de mamale ventrikeldruk en de tijd.

(Pl. vinax $=120 \mathrm{mmHg} ; \mathrm{f}=1 / \mathrm{sec})$

De Eormules resulteren in een analoge noteringswijze van figum 3.4 warmee een goed inatcht wordt verkregen van de samenhamg tussen de variabelen, het al dan niet voorkomen van algebraische loops en de invloed van een constante op variabelen. 


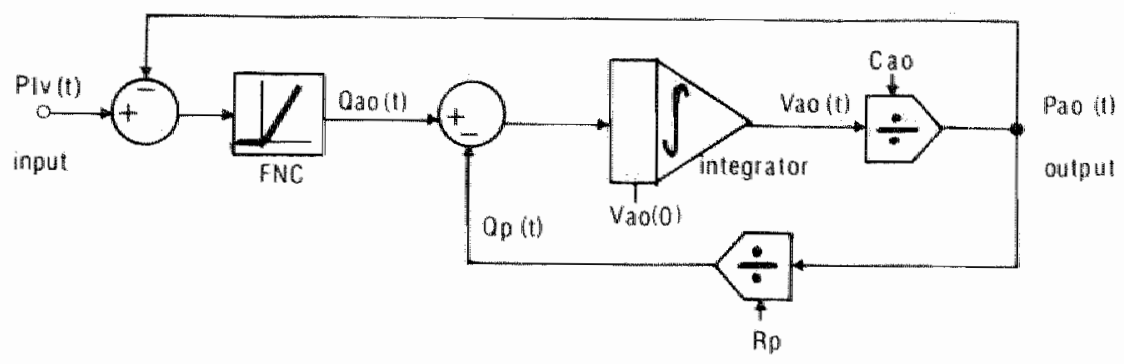

Figur 3.4: Het analoge schema vam het model dat aan AoRTA ten grondslag ligt. De druk in de aorta is een functle van de compliantie Cao en het bloedvolume in de aorta Vao(t). De druk in de aorta zelf beinvloedt de netto instroom de arta in en het moment dat de aortaklep, voorgesteld door het niet-lineaire functieblok WNC, open gaat. Het bloedvolume in de aorta is de integraal van de netto instroom $[Q \operatorname{Qol}(t)-Q p(t)]$.

Als we het model in FORTRAN IV scheijven en woor Vao(o) de startwarde $70.0 \mathrm{~m} 1$ nemen en voor de 4 constante parameters de waarde uit onderstaande tabel:

$\begin{array}{llll}\text { aortacompliantie } & \mathrm{AC} ; & \mathrm{CaO}=1.1 & (\mathrm{~mL} / \mathrm{mmHg}) \\ \text { cotale perifere weerstand } & \mathrm{TPW} ; & \mathrm{RP}=1.25 & (\mathrm{mmH} \cdot \mathrm{sec} / \mathrm{mL}) \\ \text { max. Iinker ventrikeldruk } & \text { VDMAX; } & \mathbb{P I V m a k}=120 & (\mathrm{mmHg}) \\ \text { slagfrequentie } & \mathrm{F} ; & \mathrm{f}=1 & (\mathrm{l} / \mathrm{sec})\end{array}$

dan worden de Linker ventrikeldruk (VD), de aortadruk (AD), de perifere stroom (PS) en het aorta (bloed)wolume (AV) als volgt (in FORTRAN) berekend:

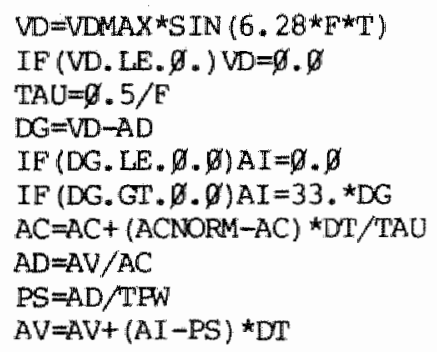

De 4 constante parameters zijn tegelijkertijd de 4 mogelijkheden om in het model te interveniëren. 
On in dte model geen storende overgangsverschijnselen te krijger dif samenhangen met een abrupte parameterverandering, vindt er een voor de gebruker van dit programma onmerkbare, langzame verandering plats. Daarvoor is de wolgende vergeltjking bij sommige interventies in het model opgenomen (in de algemene vorm):

$$
\mathrm{Cl}=\mathrm{CT}+(\mathrm{CN}-\mathrm{CI}) * \mathrm{OT} / \mathrm{TAU}
$$

warbij TAU fen tijdsconstante is, die experimenteel bepaald bij deze interventie hoort, $C N$ de niehwe ingestelle warde van de constante (cn) i.s en $\mathrm{Cl}=\mathrm{Cl}(\mathrm{t})$ het verloop heef $\mathrm{zoals}$ in figuur 3.5 getekend is.

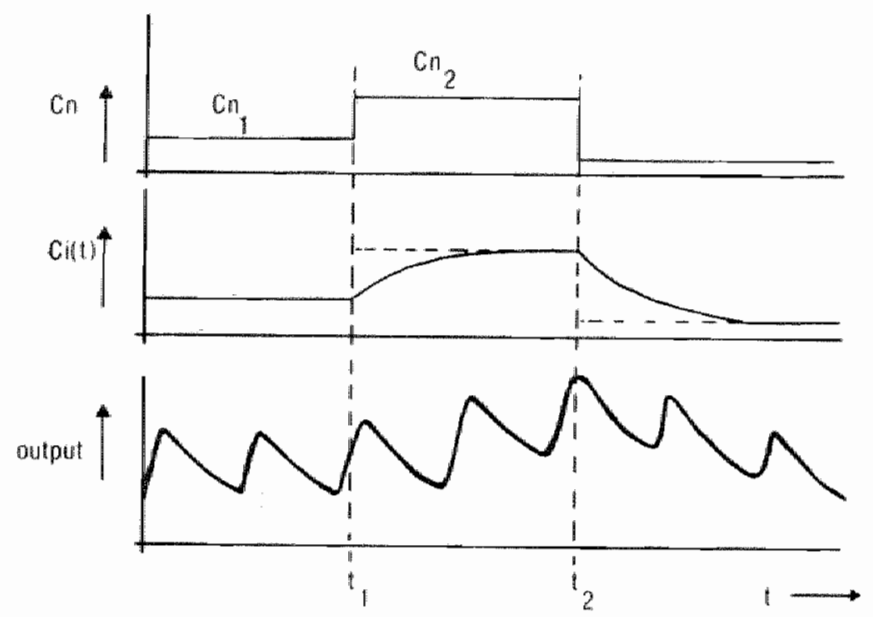

Figuur 3.5: Het effect vaneen intervent ie dient in bepaalde gevallen met een zekere tijdsvertraging op het model in te werken. Hifervoor is een le orde overdrachts functieblok te gebruiken. De stapsgewilge verandering van Cny naar $\mathrm{Cn}_{2}$ wordt als $\mathrm{Cl}(\mathrm{t})$ aan het model als interventie aangeboden. Hiermee zijn voor de student niet relevante inschakelverschijnselen die anders in de output voorkomen tot een mintmum te reduceren.

\section{Resultaten}

De bij dit model behorende normal. warden voor de diastolische en syscolische druk in de aorta $(120 / 65 \mathrm{~mm} g)$ worden bij het computersimulatieprogramma AORTA bereikt met Cao $=1.1 \mathrm{ml} / \mathrm{mmHg}$ en $\mathrm{Rp}=1.25 \mathrm{mmHg} . \mathrm{sec} / \mathrm{ml}$ bij een maximale linker ventrikeldruk van $120 \mathrm{mmHg}$ en een slagfrequentie van $1 /$ sec. Met een andere keuze van deze warden wordt een andere warde voor de aortadruk verkiegen. 


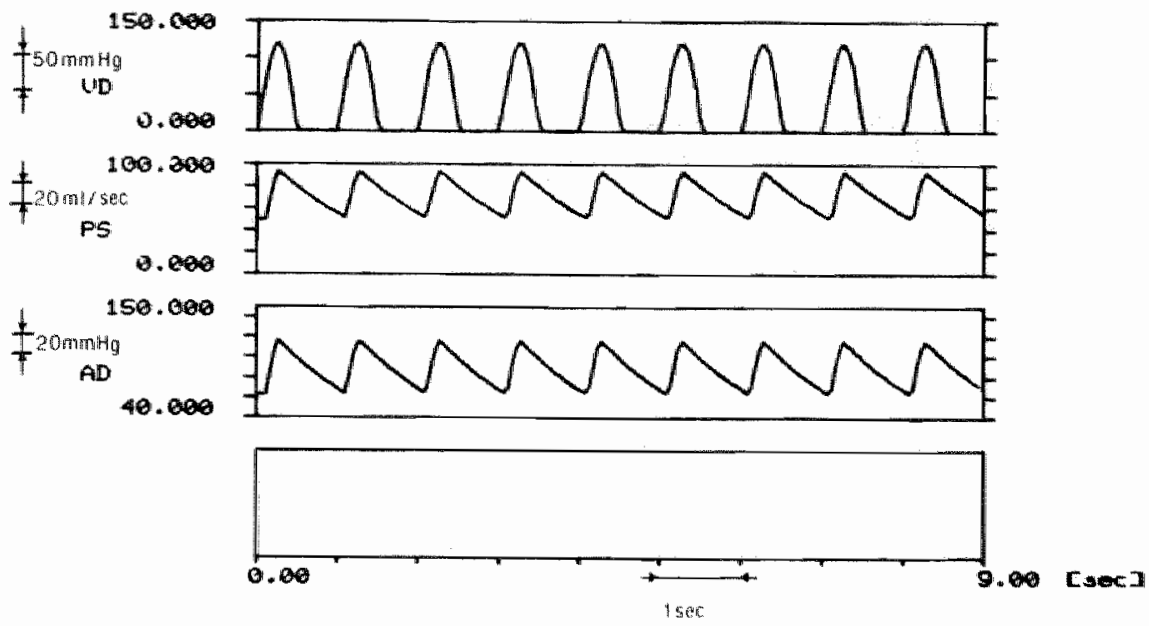

Figuur 3.6 : Het normale patroon van de bloeddruk bij AORTA.

Pao $=120 / 60 \mathrm{mmHg}$, CaO $=1.1 \mathrm{ml} / \mathrm{mmHg}, \mathrm{Rp}=1.25 \mathrm{mmHg} . \mathrm{sec} / \mathrm{ml}$. De schaalverdeling langs de 4 assen loopt bij Plv (VD) van 0 tot $150 \mathrm{mmllg}$, bij $Q p$ (PS) van 0 tot $100 \mathrm{ml} / \mathrm{sec}$ en bij Pao (AD) van 40 tot $150 \mathrm{~mm} H \mathrm{~g}$.
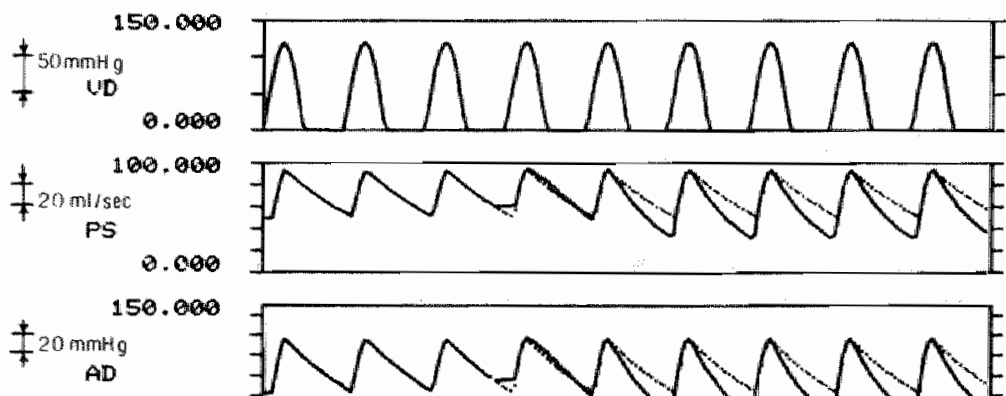

40.0100
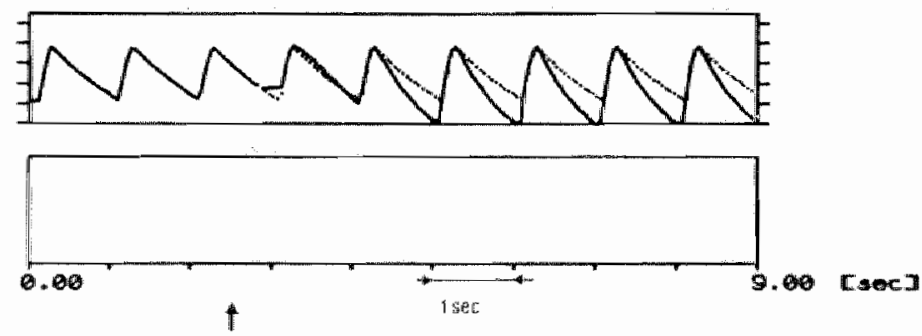

Fifuur 3.7 : De compliantie is verlagd (opt $=2.5 \mathrm{sec}$ ). De diatolische aortadruk ( $A D$ ) en de geniddelde perifere stroom (PS) z 1 in verlaagd. $\mathrm{PaO}=1.20 / 40 \mathrm{mmHg}, \mathrm{CaO}=0.55 \mathrm{ml} / \mathrm{mmHg}, \mathrm{Rp}=$

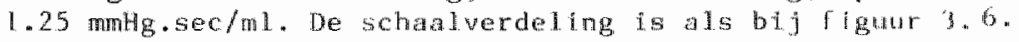

Figur 3.6 toont het normale patroun van de simulatie warbij

Pao(diastole) $=65 \mathrm{mmHg}$ en $P a d($ systole $)=120 \mathrm{mmHg}$. De druk in de arte begint te stijgen als plu(t) > Pao(t). Er is bij dit model gron terugkoppeling van de dnuk in de atca of de perffere stroom nat de linker ventrike]druk Plv(t).

In het geval de compliantie van de aorta cao wordt verlaggd, de aorta dus stijuer wordt, zal na verloop van enkele slagen de Paoldiaglole) duidelijk verlaagd zijn. 


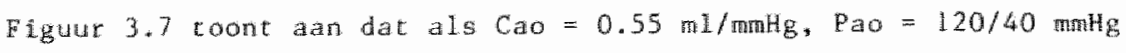
wordt. Daarbiy is de gemiddelde stroom door de circulatie afgenomen: $Q p(d i a s t o l e) \approx 38 \mathrm{~m} / / \mathrm{sec}$ en $\mathrm{Qp}(\mathrm{systole})=97 \mathrm{~m} / \mathrm{sec}$. Indien de maximale linker ventrikeldruk wordt verhoogd tot $140 \mathrm{~mm} / \mathrm{g}$ a l l het resultat zijn dat in steady state Pao(diastole) ca $40 \mathrm{~mm}$ bedraagt en pao(systole) is verhoogd tot $>135$ mmHg (figuur 3.8). Als de compliantle nog verder afneemt daalt de pao(diastole) tegelijkertijd.
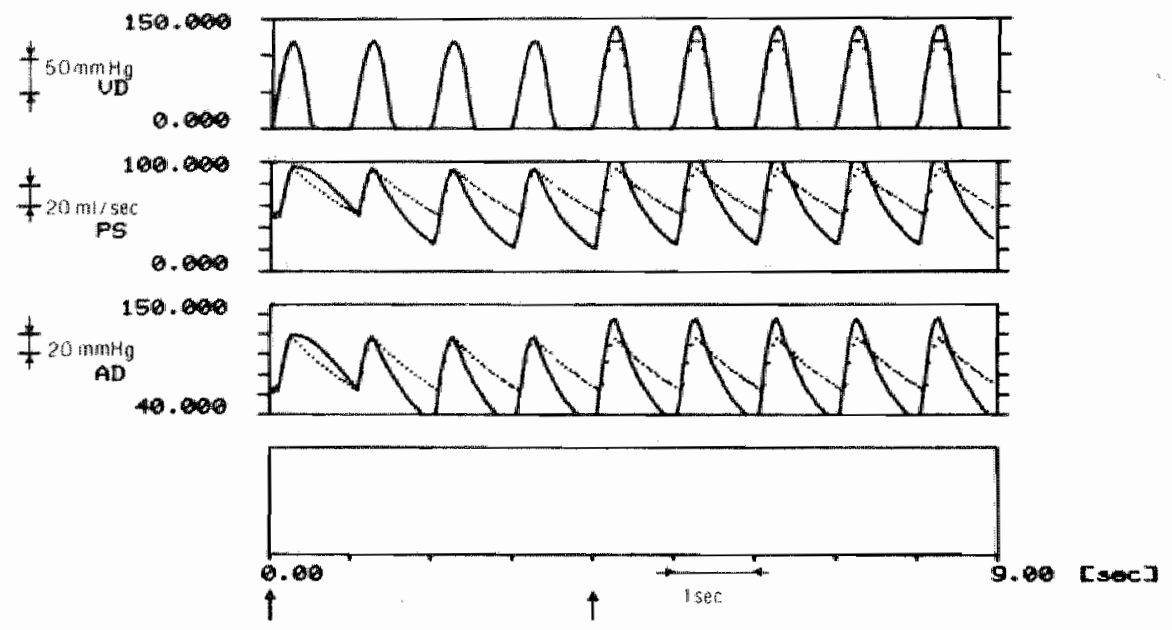

Figur 3.8 : De compliantie is verlaagd (op $t=0)$ : Pao(diastole) is verlaagd tot $35 \mathrm{mmHg}$ (Pao $=120 / 35 \mathrm{mmHg}$ ) bij CaO $=0.4 \mathrm{mil} /$ $\mathrm{mmHg}$ en $\mathrm{Rp}=1.25 \mathrm{mmHg} \cdot \mathrm{sec} / \mathrm{ml}(2<\mathrm{t}<4 \mathrm{sec})$. Op $t=4$ sec wordt Plvmax verhoogd tot $140 \mathrm{mmHg}$. Paolsystole) wordt verhoogd tot $140 \mathrm{mmHg}$. Pao $=140 / 35 \mathrm{mmHg}$. zowel de gemidelelde druk in de aorta als de gemiddelde perifere stroom is verbeterd $(4<\mathrm{t}<9$ sec) als tegelijkertijal met Cao $=0.4 \mathrm{~mL} /$ minthg ook Pl.urnax $=140 \mathrm{mmHg}$ wordt gemakt. De schat lverdeling is als bil figur 3.6 .

Bif dit model kar Pao(diastole) praktisch nihil worden. Die extreme stcuatie van een zeer stijue aortawand coont dan aan dat de aorta de ventrikeldruk ongewijigd en onvervormd doorgeet aan de periferie. Die stuatie laat duidelijk de functie var de aortazien t.b.v. een continue bloedvoon lening wan de periferie. Als de rekbarheid van da artawand afneent, en daardor ook de compliantie van de aorta b.v. bij atheroscherose, dan neemt de Pao(diastole) af, de polsdruk neemt toe on de bufferfunctie die de aorta normal heef af. De perifere stroom 6.9 . het hartminuutvolume is dan tijdens de diastole lager dan 
normal. Buiten de mogelijkheid die de student heeft on deze verlinguk druk in de arta en verlaagde perifere stroon door de periferie tw verbeteren met het verhogen van de maximale linker ventrikeldruk, kan hij de slagfrequentie verhogen. Dit leidt ertoe dat Pao(diastole) wordt verhoogd. Howel dit een verbetering oplevert, deert het de student, dat dit leidt tot een permanent verhoogde slagfrequentie. Dit is tharapeutisch echter moder gewenst.

In het geval dat de totalle perifere weerstand wordt verhoogd, dus de doorbloeding moeilijker wordt gemakt, zall de perifere stroom QP verminderen en Pao(diastole) toenemen.
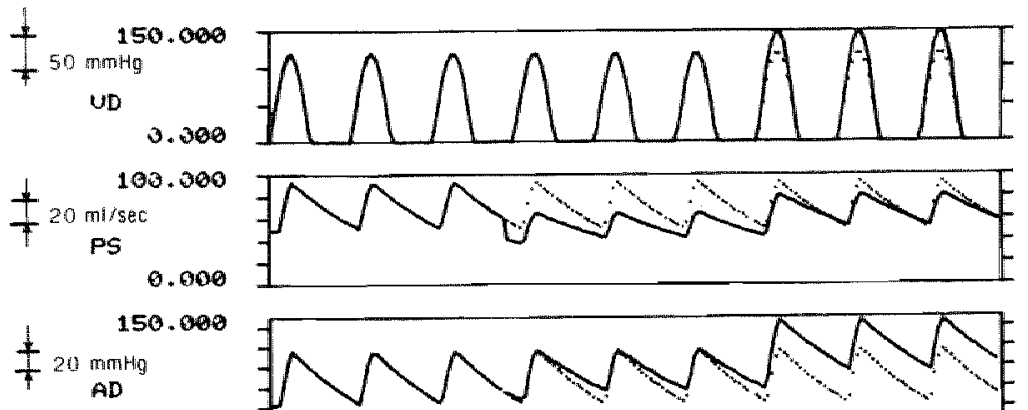

40.000
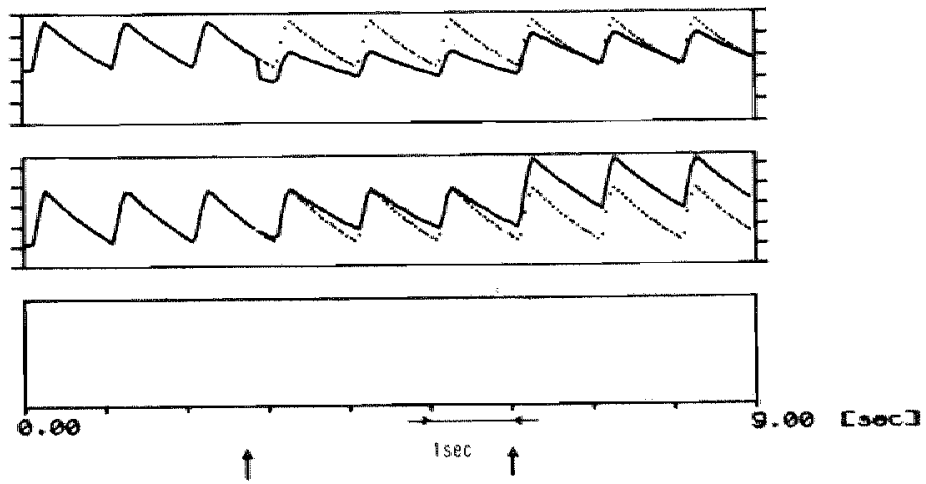

Figuur 3.9 : De totale perifere weerstand is verhoogd (op $t=2.8$ sec) tot $\mathrm{RP}_{\mathrm{P}}=1.8 \mathrm{~mm} H \mathrm{Hg}$. sec $/ \mathrm{mL}$ en $\mathrm{PaO}=120 / 80 \mathrm{mmHg}$ alls $3<t<6$ sec. Qp is blijuend verlatgd. Op $t=6 \mathrm{sec}$ wordt Plwmax $=150$ malng met $\mathrm{Rp}=1.8 \mathrm{mmHg}$. sec $/ \mathrm{mL}$ waardoor de perifere stroom toeneent en $\mathrm{PaO}=150 / 100 \mathrm{~mm}$ g wordt $(6<\mathrm{t}<9 \mathrm{sec})$.

De schalverdeling is als bij figur 3.6 .

In figuur 3.9 is $\mathbb{R p}$ verhoogd tot 1.8 mong. sec/ml wardoor de bloeddruk In de aorta wordt verhoogd. Het blijkt dat Paoldiastole) na enkele slagen $80 \mathrm{~mm} H \mathrm{Hg}$ is geworden. Bij dit model kan Pao(systole) nooit groter worden dan PIV. Er is van algezien on in dit model de maxtmalc linker ventrikeldruk als functie van de stroom $Q p$ in het model ap te nemen. Illustratiever voor de studenten is om ze zelf het hartminutwolume te laten regelen met de maximale linker ventrikeldruk Plvmax. In figuur 3.9 is getracht de verladgde Qp te herstellen door 
PI vark = 150 inthg te maken. Het gevolg $\mathbb{L}$ s dat zowel de Pao(diastole) als Pao(systole) is verhoogd tot $150 / 100$ moltg bij een verhoogde totale perifere weerstand $\mathbb{R}_{p}=1.8 \mathrm{mmHg} \cdot \mathrm{sec} / \mathrm{ml}$.

\section{Discussie}

Het model AorTA is als een van de eerste modellen geimplementeerd in het RL-simulatiesysteem en met dit simulatieprograma is ook de meeste ervaring opgedaan In het kader van het medisch curriculum, $m$, $n$. in het blok ower atherosclerose (1.5). In het studiejaar $1977 / 1978$ werd het an studenten als demonstratie gepresenteerd werkend onder het THTSIM simulatiesystem. In het studiejaar $1978 / 1979$ werd het gepresenteerd in een oude versie van het flusimulatiesysteem op een VT55, terwijl AORTA pas in 1979/1980 voor het eerst op de Tektronix-twee-terminal werste van het RL-simulatiesysteen werd opgenomen. Inmiddels is het programma door een groot antal studenten gebruikt. Voor deze studoncen fungeert AORTA in het algemeen als een eerste kemnismaking met het gebrutk wan wiskundige modellen in de medische wetenschappen. De studenten werken meestal met twee tegelijk gemiddeld $20^{\prime \prime}$ a 2 uur in het onderwljsblok ower atherosclerose aan dit programa. Zij maken hiervoor gebruik van casuistiek die in de handleiding bij het blok wardt gepresenteerd (zie append $i x$ 3.1). Het doel van deze casuistiek is de studenten an te zetten tot nadere bestudering van enkele fundamentele relaties uit de hemodynantca.

Het model dat an het programa AORTA ten grondslag $1 \mathrm{igt}$ is de meest eenvoudige voorstelling van de aorta en grote arterian als windketel. In dit windketel model is geen terugkoppeling van de perifere stroom nara de pompwerking van het hart. De student wordt op deze bewust gekozen simpliflcate van de werkelijke situatie in het menselijk hartvatatelsel geatcendeerd in de probleemstelling rondon de verandering van de totale perifere werstand. Op deze wije leert de student automat lsch een van de belangrijke aspecten van wiskundige model vorming: de ultkonst wan een model hangt af van hetgeen de modelbouwer uit de werkelijkheld heeft nagebootst. Een tweede moment warop dit duidelijk wordt, is wanneer de student opmerkt dat de vorm wan de gesimuleerde drukgolf in de aorta afwljkt van de werkelijke. Vrijwel alle studenten observeren spontaan dat de zgn. dicrotische plek ontbreekt. Nadere analyse van het model leert de student dat dit ook te verwachten is. 
Het optreden van deze plek hangt samen met stroomverschijnselen in de aorca bij het sluiten van de aortakleppen. Deze stroomverschijnselen worden in het iskundig model echter niet beschreven. On de studenten enig gevoel te geven voor het kumnen veranderen van een model op basis van experimentele observaties, kunnen ze zelf de ventrikeldruk aanpassen bij een gewijzigde perifere stroom.

Maast deze bewust gekozen vereenvoudigingen t.o.v. de werkelijkheid bevat het model een goede mogelijkheid de effecten van verandaringon in factoren als compliantie en weerstand van het vatstelisel na re botsen. M.n. de mogelijkheid het dynamisch gedrag van dit model bij veranderingen in deze parameters te demonstreren makt AORTA een geschik leermiddel voor medische studenten. In hoofdstuk 10 zal nog uitvoeriger worden ingegaan op het gebruik van AORTA in het medisch curriculum. 


\section{Referenties}

ALES M.G.J.,

A. mathematical model of the dymamics of the left ventricle and the coronary circulation. Acadenisch proefschrift, Mastricht 1978.

Berrards, J.A., L. W. Bouman. Fyslologie yan de mens. Bohn, Scheltema \& Holkema, Ltrecht, 1979. Colveman, T.G.,

Simulation of biological systens: The circulation of blood. Simulation 28, $201(1977)$.

Farrar, D.J., H.D. Green, M.G. Bond, W.D. Wagner and R.A. Gobbée, Aortlo pulse wave velocity, elasticity, and composition in a nontuman primate model of atherosclerosis. Circ.Res. 43, 52 (1978).

Katz, \$., J.G.Hollingsworth, H.T. Blackburn, H.T. Cateer jr., Use of computer simulation in teaching physiology: student laborntory. Comput. Educ. 2, $307(1978)$.

Min, F. B.M., H.A.J. Struyker Boudier, Computer simulation in problen oriented medical learning. In: Procedings International Simulation and Gaming Association Conference (red. K. Bruin), Leewwarden (1979), vol. II, p 186-196. Noordergraaf, A., G.T. Meester,

Hemodynamics and the heart. Bibl.cardiologica 30,75 (1973). Noordergraat. A.,

Circulatory system dynamics. Academic Press lnc., New York (1978). struyker Boudier, H.A.J., F.B.M. Min,

Computer Simulation of the cardiowascular system. In: Proceedingt Incernational Simulation and Gaming Association Conference (red. K. Bruin), Leeuwarden (1979), vol. I, p 321-328.

Westerhot, N., G. Elzinga, P. Sipkema, An artificial atcerlal system for punping hearts. J.Physiol. 31, 776 (1971).

\section{Literaturis ist}

Brubakk, A.O., R. Aaslid, Use of a model for simulating individual aortic dyamies in man. Med.Blol. Comput. 16, 231 (1978).

Ir luchidima, J...

Cardiovascular Physiology. Igaku shoin LTD. Tokyo (1972).

Sagawa, K., K. Nakay ama,

Simulation of heart muscle contraction. Simulation $44,173(1976)$. Schaat, B.W., M. H. Abbrecht,

Digltal computer simulation of human systenic arterial pulse wave transmission: a nonlineair model. J.Blomech. 5, 345 (1972). Suga, H.

Importance of atrial compliance in cardiac performance. Circ. Res. 35. $39(1974)$.

Weygandt, C.M., R.H. Cox, G. Karreman, M.L. Cole, Pressure-filow relationships $\mathrm{in}$ a model for the arterial system. Bull. Math.Blol. $40,95(1.978)$. 
HOOEDSTUK 4

Computersimulatieprograma CARDTO

Onderwijsdoel

Het computersimulatieprograma CARDIo make het studenten mogelijk te experimenteren met de bloeddrukregulatie en de daaran ten gronds lag liggende principes bij een gezond mens. Het programa simuleert een experimentele laboratoriumomgeving. war hemodynamisch onderzoek kan worden verricht, variabelen kunnen worden geregistreerd en war interventies in het model problemloos kumnen worden utigevoerd. Het programma CARDIO is vak het eerste moment warrop de student $z$ ijn inzichten over de circulatie en de bloeddrukregulatie kan toetsen aan de hand van problemen uit de praktijk. Hij kan met dit slmulacteprogramma een hele serie experimenter uitvoeren, zoals het simuleren van hartzwakte, hoge bloeddruk, verminderde nierfunctie, bloedverlies, veneuze constrictie, arterie le constrictie, inspanning en ondervoeding. Deze ingrepen kunnen op een in paragraat 2.2 besproken manter ook in thet model worden aangebracht en als een patientencasus worden gekozen. Bi die vorm van presentatie kan de student gevraagd wordem een diagnose te stellen en uitgaande van de grafische weergave van een gewijzigd hernodynamisch beeld therapeutisch in te grijpen. Mogelijkheden hicrbij zijn dan het toedienen van een geneesmiddel zoals een hartglycoside (digim talis), vaatverwijder, diureticut, sympathicolyticum of noradrenaline.

Model van het cardiovasculaire system

Het model van het computersimulatieprogramima CARDIO is gebaseerd op een model van het hart-vaatstelsel wan een gezonde mens. Het bestaat uit viff compartimenten: het hart, het vaatscelsel, de viloeistoffen in en buiten het watstelsel, het zenwreflexsyseem en de nier. Het model bevat een antal relatles tussen paraneters in deze compartimenten en bestat uit circa 60 vergelifkingen inclusief vier integraal vergelijkingen.

Dit model van de bloeddrukregulatie en het cardiovasculaire systeem valgens Coleman, onderscheidt drte belangrijke geregelde grootheden. 1. De grootte van de vaatweerstand wordt voornamelifk bepaald door mecabole en neurale factorem. Op deze wijze is het mogeli ilk de 


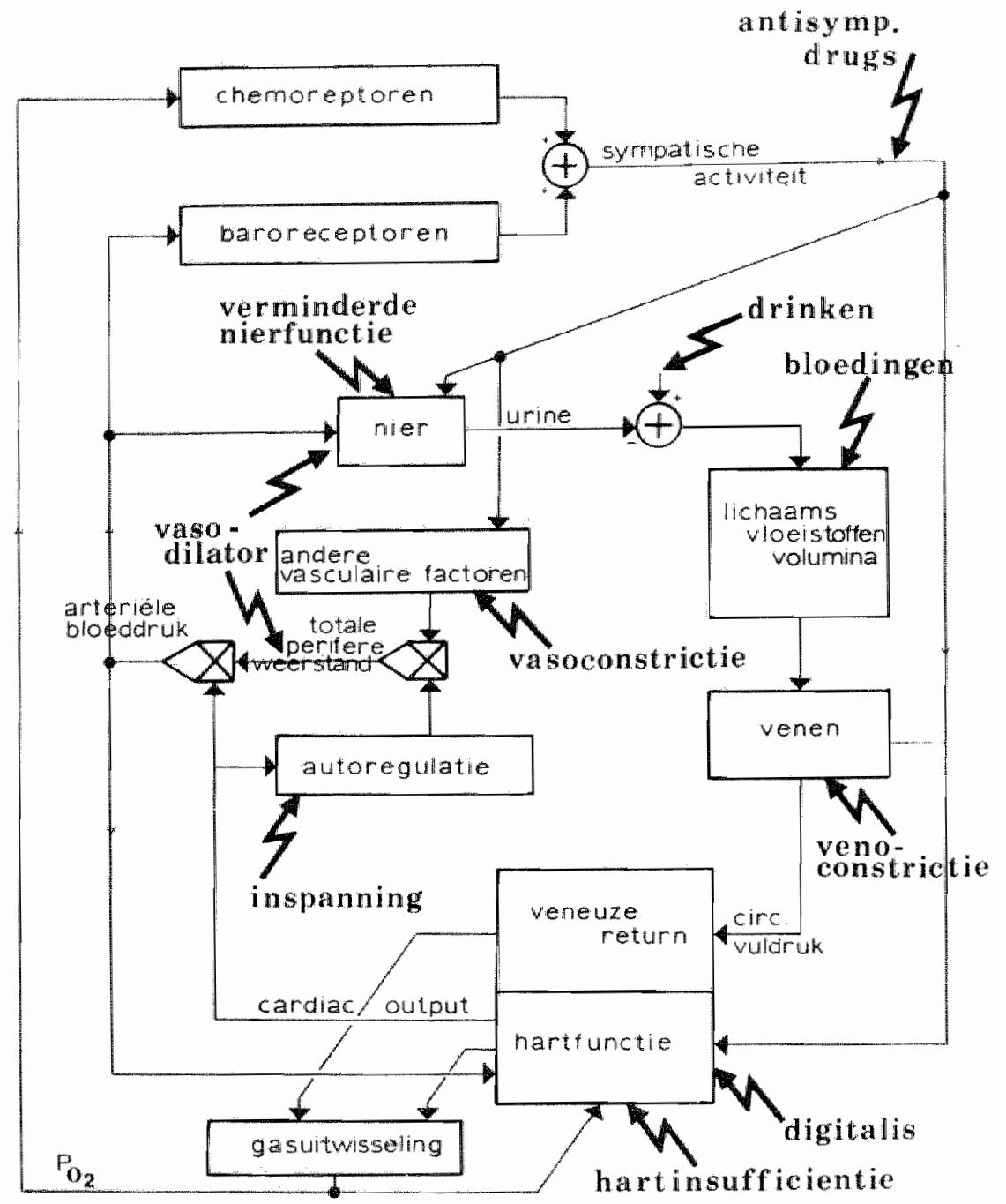

rigur 4.1: Model van de bloeddrukregulatie van het computersimulateprograma CARDTO met daarin aangegeven de mogelijkheden voor een incerwentie.

dootbloeding van de verschillende weefsels in het model zo constant mogellyk te houden (autoregulat le) of aan te passen an de behoefte. Het handhaven van de doorstroming van een adtal weefsells is een van de belangrijkste cardiovasculate fysiologische prioriteiten van het intacte organisme.

2. De gemiddelde arterięle bloeddruk wordt acun geregeld door de zenuweflexen, n.n. de baroreceptorreflex (de bloeddrukregulatie door middel. van het renine-angiotensine-systeen is bij het programma CARDro niet opgenomen). Op de lange termijn wordt de bloeddruk geregeld door de nierfunctie die het extracellulair vloeistaf- 
3. Het hartminuutvolume wordt primair bepald door de veneuze terugstroom. Bovendien kan het hartminuutvolume rechtstreeks door de pompfunctie van het hart worden beănvloed.

Figuur 4.1 bevat een schematische weergave van de bellangrijkste relaties in het model. De incerventies die bij dit model mogelijk zijn en hun aangrijpingspunten staan erbij vermeld. Tabe 14.1 geeft de belangrijkste variabelen wan het model wan het computersimulatieprogramma CARDIo (Guyton et al. 1972 en 1976; Coleman et a1. 1974, 1977, 1978 en 1979; Struyker Boudier en Rahn, 1979).

Tabel 4.1. Lijst met de belangrijkste variabelen en hun normaal warden van het model van het computersimulatieprograma CARDIO. In de appendices 4.2 en 4.3 worden de constante modelparameters gegeven.

- Arteriële bloeddruk (gemiddelde)/ Mean Arterial Pressure (AP)

- Hartminutwolume/Cardiac Output (CO)

- Totale perifere weerstand/Total Peripheral Resistance (TPR)

- Urine productie/Urine Output (Uo)

- Hartfrequentie/Heart Rate (HR)

- Bloedvolume/Blood Volume (BV)

- Rechter atrium druk/Right Atrial Pressure (RAP)

- Sympathische zenuwactiviteit (chemoreceptor) (CHEMO)

- Sympathische zenuwactiviteit (baroreceptor) (BARO)

- Totale sympathische activiteit/Symp. Autonomic Outf low (SYMPS)

- Arteriële $\mathrm{O}_{2}$ druk/Arterial $\mathrm{O}_{2}$ Pressure (PO2)

- Stikstof gehalte van het ureum in het bloed/ Blood Urea Nitrogen (BUN)

- Extra cellulaire vloefstof volume/Extra Cellular Fluid Volume (ECFV)

- Gemiddelde circulatoire vuldruk/Mean Clrc. Filling Pressure (MCrP)

- Glomerulaire capillaire druk/Glomerular Capillary Pressure (GP)

- Drukgradient veneuze terugstroom/Press. Gradient for Veneus Return (DELP)

- Renale arteriéle weerstand/Renal Artery Resistance (RAR)

- Ureum vorming/Urea Formation (BUNT)

- Ureum uitscheiding/Urea Excretion (BUNo)

- Dedeem/Edema (ED)

- Weerstand wan de veneuze terugstroom (RVR)

100 mont

$5000 \mathrm{~m} 1 / \mathrm{min}$

$0.02 \mathrm{mmHg} \cdot \mathrm{min} / \mathrm{ml}$

$1 \mathrm{mil} / \mathrm{min}$

$70 / \mathrm{min}$

$5000 \mathrm{ml}$

$0 \mathrm{mmHg}$

0 eenheden

1 eenheden

1 eenheden

$100 \mathrm{mmH} \mathrm{gg}$

$10 \mathrm{mg} \%$

$15000 \mathrm{~m} 1$

$7 \mathrm{mmHg}$

$60 \mathrm{mmHg}$

7 namH

$1.67 \mathrm{~mm} / \mathrm{gg}$. min/mi

$10 \mathrm{mg} /$

$10 \mathrm{mg} \%$

0 eenheden

0.0014 酔的Hg $\mathrm{m} / \mathrm{m} / \mathrm{ml}$ 
Het model dat aan het computersimulatieprograma CARDIo ten gronds lag 1igt, is oorspronkelijk ontworpen door Coleman in 1977 (Coleman, 1977) en verder ontwikkeld en uitgetest aan de Rijksuniversiteit Limburg. De beschrljuing van dit model gat uit van de volgende compartimenten indeling:

1. het hart

2. het vatstelsel

3. de vloelstoffen in en buiten het vatstelsel

4. het zenuwref lexsysteem

5. de nier

Deze zullen achter elkar worden besproken warbij de ForTRAN notaticwijze en de aloge notatiewijze elkaar aan zullen vullen.

In de appendices 4.2 en 4.3 worden de ultgangswarden van de constanten en In tabel. 4.1 die van de varlabelen gegeven.

\section{Het hart}

In dit model is het basale hartminuutvolume (COB), d.w.z. het hartminumvolume zonder fnvloed van het autonome zenuwstelsel, een functie van de rechter atriundruk (RAP). De rechter atriumdruk (RAP) wordt berekend uit de gemiddelde circulatoire vuldruk (MCFP) en de drukgradient voor de veneuze terugstroom (DELP) via de relatie:

\section{RAP $=$ MCE $\mathrm{P}-$ DELP}

De geniddelde circulatoire vuldruk (MCFP) is een functie van het bloedvalume (BV) en de mogelijkheid wan het vaatsysteem m. de venen on wich met bloed te vullen.

$$
\mathrm{MCFP}=0.0047 *(\mathrm{BV}-\mathrm{BV} \emptyset)
$$

Met de invloed van veneuze constrictie en het autonome zenuwstelsel wordt dat echter

$$
\text { MCFP }=0.0047 *(B V-B V \emptyset /(\operatorname{VENCON} *(2 * A O+.8))) \text {. }
$$

Het hartminumolume (CO) wordt, zoals reeds eerder is vermeld door de basale cardiac output ( $C O B$ ) en een hartfunctie parameter bepald $(H F)$. Deze hat functie (HF) is een functie van de rechter atrium druk (RAP), de gemiddelde arteriële bloeddruk (AP), de sympathische zenuwactiviteit (AO), eventuele hartglycoside (DIGI) en de basale hartsterkte (HSB). Dit wordt als volgt berekend: 


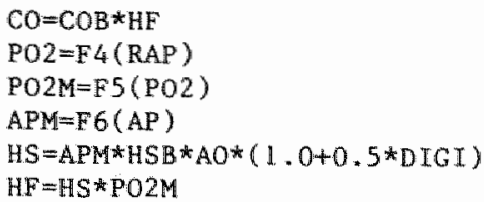

De analoge notatiewijze is:

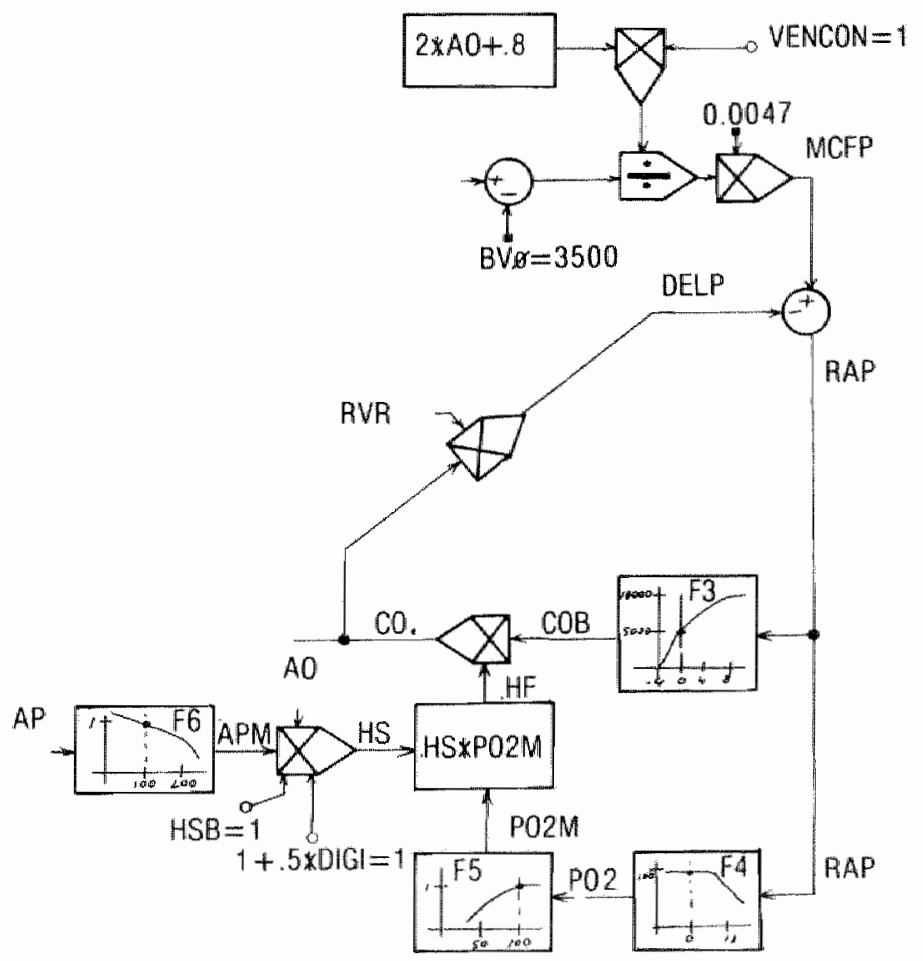

Het vaatstelsel

Veel weefsels in het lichaam functioneren optimal als de stroom door het weefsel of orgaan binnen bepalde grenzen constant bijfft. Het regelnechanisme dat hiervoor zorgdrage, tracht dit te realiseren via weerstandsveranderingen. Dit autoregulatiemechanisme warleert in eik weefsel voor wat betreft "t ljdsconstante" en "gatn". 
In dit model is getracht een overall beschrijuing wan het autoregulat le fenomeen op te nemen. Woor de som van alle individuele weefseldoorstromingen (het hartminuutwolume, co) geldt het volgende: stel ex treedr een sprongsgewijze veranderlng op in het hartminutvolume (Co), dan zou bij een instantane totale autoregulatio een sprongsgewijze verandering van de basale totale perifere weeratand (TPRB) optreden warvan de eindwarde wordt bepald dook een niet-lineaire functie (Fll). De feitelijke aanpassing van de vatwerstand geschiedt met een zekere vertraging, warvan de tifdsconstante wordt bepald door de snelineid van autoregulatie. In het model wordt hiervoor de factor TPRD aangenomen, warna het onderstand schema de snelheid van aanpassing geeft.

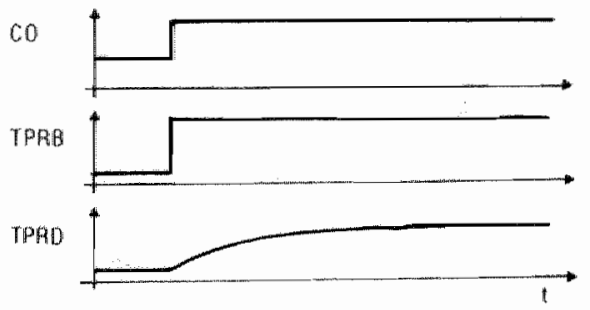

Dit resulteert in de wollgende formules:

$$
\begin{aligned}
& \text { COM=CO* }(T P R \| T P R M) \\
& D E L C O=C O M-5000 * M D \\
& T P R B=F \perp \perp(D E L C O)
\end{aligned}
$$

en DYDT $=$ TPRD*

TPRD $=T P R D+D Y D T$ DT

en TPRM $=A 0 * V A S C O N * T P R D /((1.0+D$ L LAT $) * M D)$

$T P R=1.0 /(50 . * A V F+1.0 / T P R M)$.

De weerstand woor de veneuze rerugstroom (resistance to venous return of RVR) is voor een deel een constante functie en voor een deel een functie van de cotale perifere weerstand (TPR) en als de invloed wan een Ab-fistel hler op mogelijk moet zijn wordt een goede benadering gegeven doon:

$$
R \cup R=0.025 * T P R+0.0009 /(1+0.8 * A V F)
$$

Het arterto-wereus fistel (AVE) is nomal 0 en de totale perifere weerstand normal 0.02 (mmHg.min/ml), zodat RVR normaal 0.0055 mrng. $\mathrm{m} / \mathrm{n} / \mathrm{ml}$ is. De geniddelde arteriele bloeddruk (AP) is het product van de totale perifere weerstand en de cardiac output.

$A \mathrm{P}=\mathrm{CO} * \mathrm{TPR}$

De analoge notat lewijze is: 


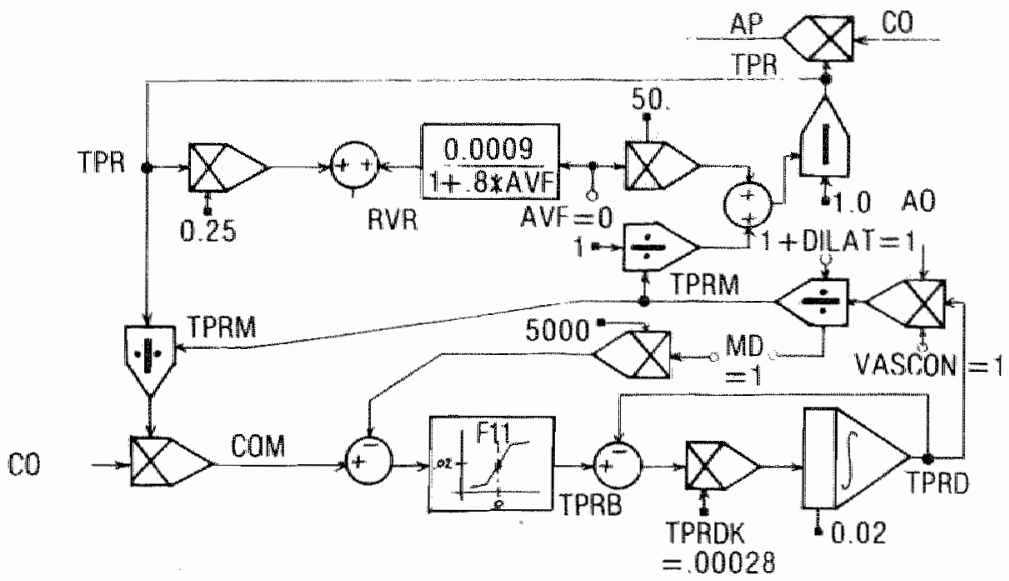

De_yloeistoffen_in_en buiten het vaatstelgel

Het extracellulair vioeistofvolume (ECFV) wordt direct beinvloed door de wloeistof die het licham opneeme minus dat wat het licham vertaat. ECFV $=\int$ ("intake" - "output") dt. Hierbij is ECFV(0)=15000 ml en de "intake" en "output" is $1 \mathrm{ml} / \mathrm{min}$.

De wateropname van het lichaam (WIN) wordt op $1 \mathrm{ml} / \mathrm{min}$ gesteld. De urine output (UO) is $1 \mathrm{~mL} / \mathrm{min}$ en het bloedverlies (BL) is normal $0 \mathrm{~m} 1 / \mathrm{min}$.

In het model wordt het extracellulair vloeistofvolume in ml (ECFV) en in liters (EL) berekend.

\section{DYDT $=W I N-U O-B L$ \\ $\mathrm{ECFV}=\mathrm{ECFV}+\mathrm{DYDT} \times \mathrm{DT}$ \\ $\mathrm{EL}=\mathrm{ECFV} / \mathrm{LOOO}$}

De extracellulaire vloelscof verdeelt zich ower het plasma en het interstitum. In het model is het bloedvolume (BV) valgens de functie F 1 en oedeemvorming (ED) volgens functite Flo (zie onderstatand Figur) afhankelijk van het extracellulaire vloeistof volume. De analoge notatewijze is:

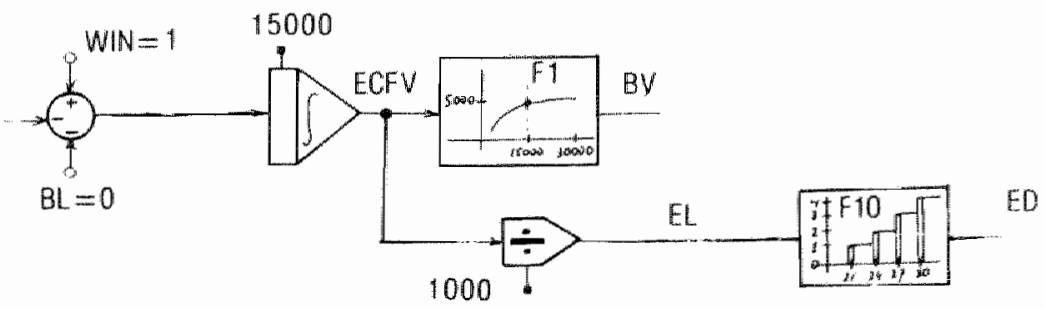


Het zentigreflexsysteem

De baroreceptor Invloed na adaptatie (BARO) is gelijk alan:

\section{$B A R O=B A R O B-A D P$}

warbij de adaptatie (ADP) normall 0 is. De tijdsconstante van deze reflex is BAROK. Het totale baroreceptorreflex gedeelte is dan verder nog:

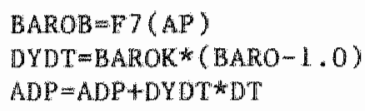

De chemoreceptorbijdrage aan de totale sympathische outflow (CHEMO) wordt bif dit model als een functie van de zutrstofspanning (PO2) beschouwd. Als de zuarstofspaning hoger wordt, wordt de chemoreceptor activiteit kleiner. $\mathrm{CHEMO}=\mathrm{F} 8(\mathrm{PO2})$

De autonome zenuactiviteit $(A O)$, watran de waarde in de normale sltuatie op 1 wordt ingesteld, is afhankelijk van de chemc- en baroreceptor activiteit, een eventuele adrenerge blokkade (BLock), een eventuele feochromocytoom (PHEO) -die een excessieve sympathische activiteit ontplooit-en een eventuele alpha-adrenerge invloed van norepinephrine (NOREPI). De harterequentie is direct een lineaire functle van $A O$.

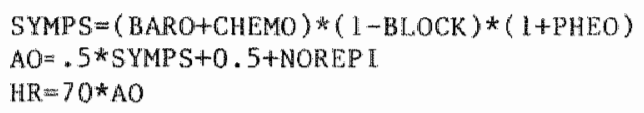

De analoge notatlewijze is:

P02

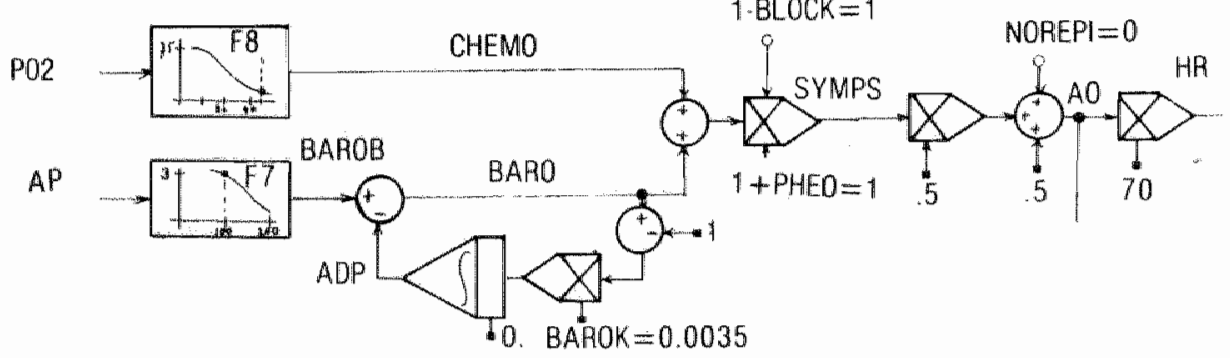

1. $B L O C K=1$

De nier

De nierfunctie is afhankelijk van de samenstelling van het bloed, andosteron, meuronale factoren, angiotensine, vasopressine en de gemiddeIde arterièls bloeddruk. In dit model is de basale urine output (uoB) $1 \mathrm{ml} / \mathrm{min}$ een functie van de gemiddelde arterièle bloeddruk (AP), de bassle renale arteriele weerstand (RARB), de autonome output (AO) en exn vasodilatatie ractor (DMAT). 
De basale urine output is de urine output wordat er andere invloeden op worden uitgeoefend zoals niermassa en diuretica invloeden (DI).

De urine output wordt dan:

$\mathrm{UO}=\mathrm{UOB} * \mathrm{RM} *(1.0+2.0 * \mathrm{DI})$

De stikscofconcentratie in het bloed hangt af van de niermassa (RM), de proteine-innane (BUNI) en de basale urine output.

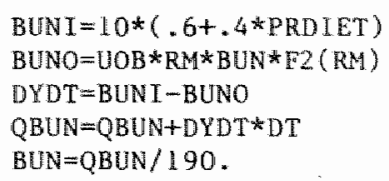

De analoge notatiewijze is:

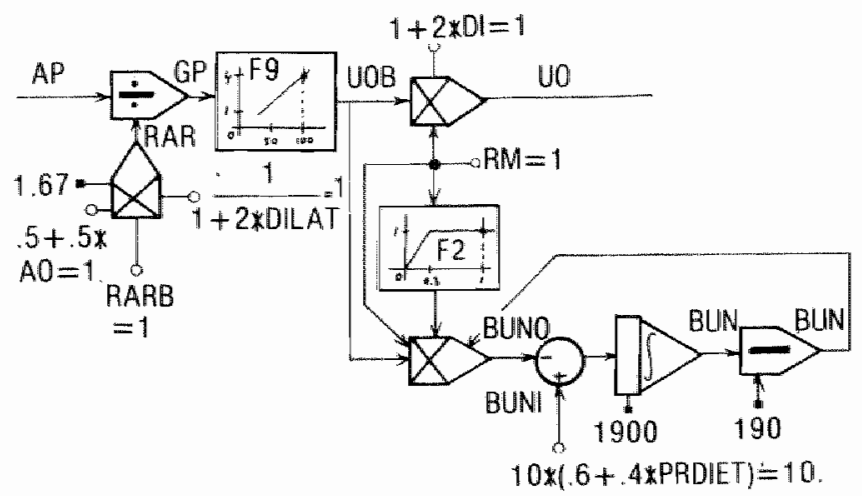

Irl appendix 4.8 en 4.9 wordt de complete FOR TRAN source en het analoge schema gegeven. 
De nomale warden voor de gemiddelde bloeddruk (AP), het hartminuutvolume (Co), de totale perffere weerstand (TPR), de urine output (Uo) en de hartfrequentie (HR) zijn bij het computersimulatieprograma CARDTo met de gegeven startwaarden en zonder een interventie onveranderlijk $(A P=100 \mathrm{mmHg} ; C O=5000 \mathrm{~mL} / \mathrm{min} ; \mathrm{TPR}=0.02 \mathrm{mmHg} \cdot \mathrm{min} / \mathrm{mL}$; vo $=1 \mathrm{~m} 1 / \mathrm{mLn} ; \mathrm{HR}=70 / \mathrm{min})$.

Deze 5 belangrijke hemodynamische variabelen kunnen worden aangevuld met het extracellulaire vloeistof wolume (ECFV), het bloedvolume (BV) of de rechter atrium druk (KAP). Deze variabelen zijn normal niet gemakkelifk te meten. B1j de hier beschreven casulstiek spelen dergelijke vartabelen een belangrijke rol. In tabel 4.2 wordt aangegeven welke berichter er kunnen werschijnen op het beeldscherm als een variabele boven of onder een bepalde grenswarde komt.

Tabel 4.2 : Lijst met symptomen, die voorkomen in het computersimulatieprogramma CARDIO. Aangegeven is boven of onder welke warde een variabele moet komen om een boodschap te genereren (verklaring van de naam van de variabele in tabel 4.1).

$$
\begin{gathered}
40<\mathrm{PO} 2<80 \\
35<\mathrm{PO} 2 \leq 40 \\
30<\mathrm{PO} 2 \leq 35 \\
\mathrm{PO} 2 \leq 30 \\
\mathrm{AP}<85 \\
1<\mathbb{E D}
\end{gathered}
$$

Dokter, ik kan geen lucht meer krijgen.

Dokter, $1 \mathrm{k}$ weet niet goed meer wat er met mij gebeurt, ik raak de kluts kwijt.

De patient wordt blauw.

De patlënt raakt bewusteloos.

Dokter, ik voel me zo dulzelig.

Dokter, tk heb last van dikke voeten; mlin schoenen knellen zo.

\section{Hare Infarct}

In flguur 4.2 is het hemodynamisch effect van een licht hartinfarct nagebootst. Op het $\mathbb{t n}$ de $\mathbf{f g u u r}$ a angegeven t1jdstlp is de contractlekracht van de hartspler (HSB) met $30 \%$ verminderd. Het hartminuutvolume daalt sterk terwlj1 het baroreceptorreflex mechanlsme de daling in de bloeddruk, dle blj dit model optreedt, tracht te compenseren wat te zlen is aan de stijging van de hartfrequentle (HR). Als de slmulatie wordt voortgezet, zifn er bif grondige inspectle van het model geen slgniffcante afwikingen na twee weken the constateren bij een aantal gemeten en geregistreerde model varlabelen. 

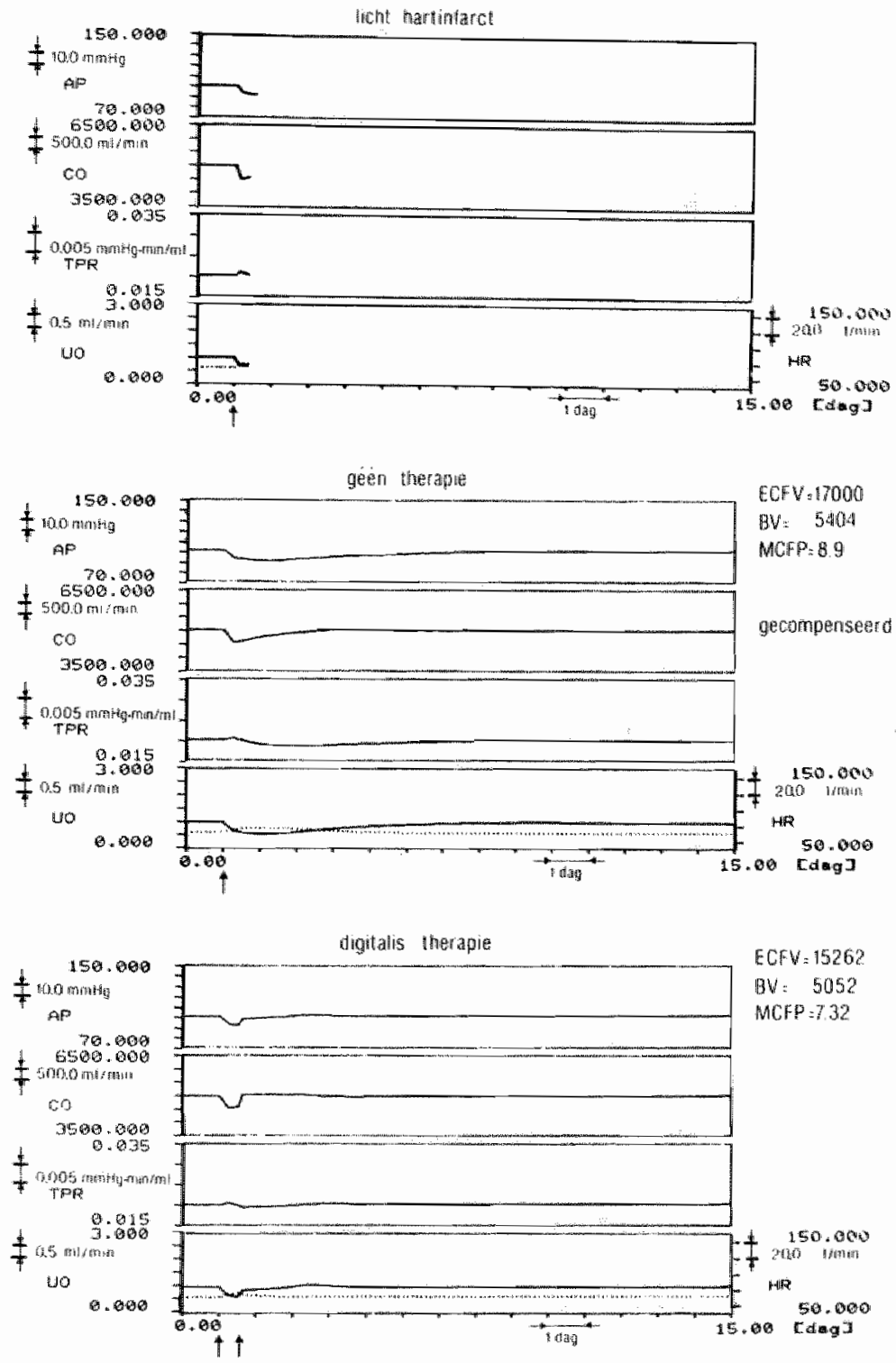

Figuur 4.2 : Casus licht hartinfarct. De basale hartsterkte (HSB) neemt plotseling af tot 0.7F. In dit geval is er nog compensentie mogelijk zonder digitalis.

Schaalinstelling:

$t$-as wan $0 \mathrm{t} / \mathrm{m} \quad 15$ dagen

le grafiek gemiddelde arterièle bloeddruk (AP) van 70 $\mathrm{t} / \mathrm{mi} 150$ moritg

2 e grafiek hartminuutwolume (co) van $3.5 \mathrm{c} / \mathrm{m} 6.5 \mathrm{l} / \mathrm{min}$

3e grafiek totale perifere weerstand (TPR) van 0.015

$t / \mathrm{m} 0.035 \mathrm{E}$

4 graflek urine output (UO) wan $1 \mathrm{t} / \mathrm{m} 3 \mathrm{ml} / \mathrm{min}$ en hartfrequentie (HR) van $50 \mathrm{~L} / \mathrm{m} 150 / \mathrm{m}$ in (gestippeld). 

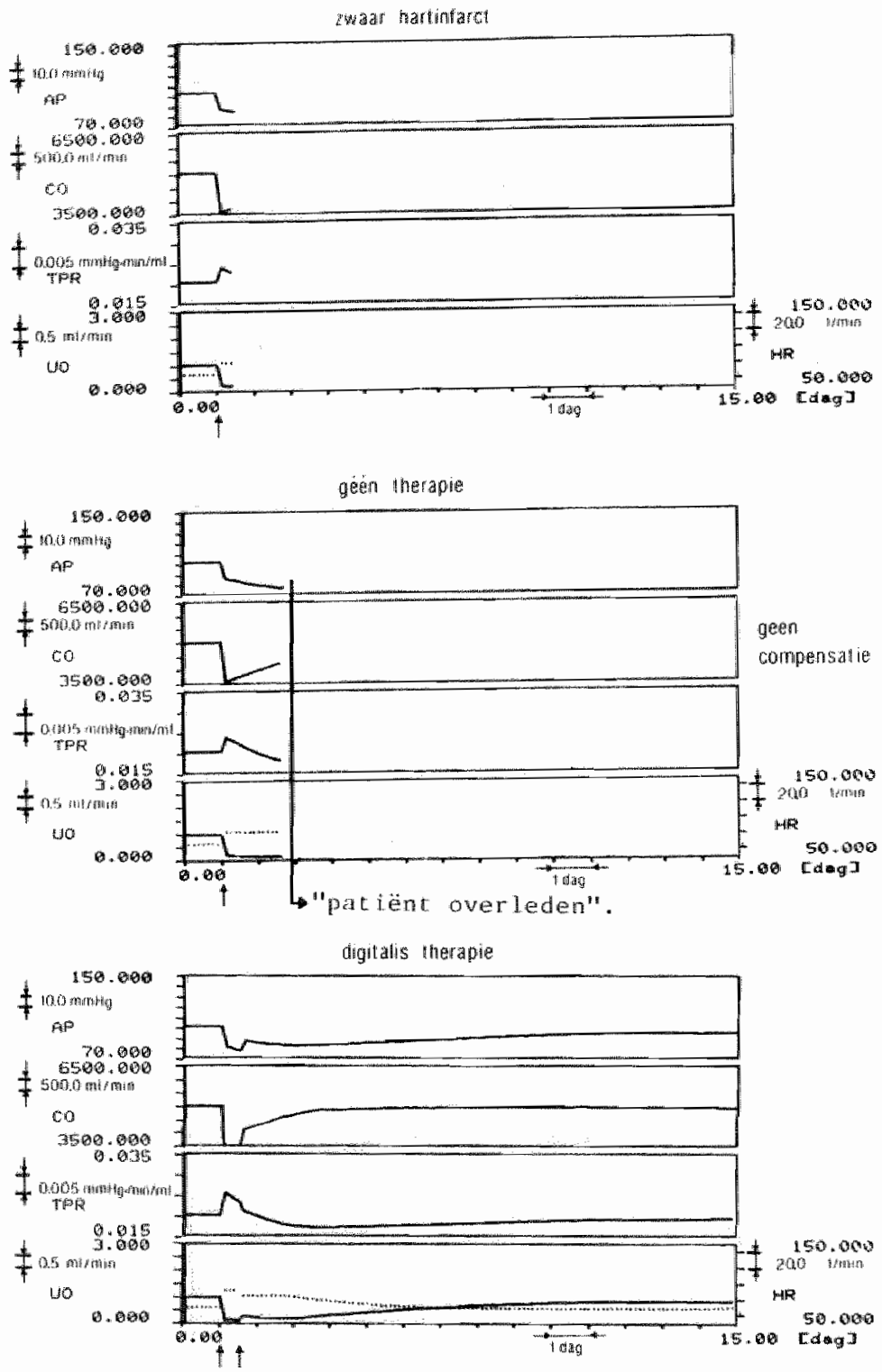

Figuur 4.3 : Casus zwar hartinfarct. De basale hartsterkte (HSB) necht plotseling af tot $0.31 \%$. Bij deze casus is geen compentat it meer mogellik max als er voldoende digitalis wordt gegeven (1.LE) averlijdt de patient niet. Schatinstelling als bi Elguur 4.2. 
Andere variabelen veranderen wel. Naukeurige andyse van de simulat iadata net de "inspecteer mode" comt dat er een renale retenrie wam waht is. Na 14 dagen is het ECFV werhoogd tot $17000 \mathrm{ml}$ en het blowdulume (BV) tot $5400 \mathrm{ml}$. Zo wordt het vermogen van het hart adequat per tijdseentheid een hoeveelheid bloed te pompen gecompenseerd doar een overvulling van het vaatstelsel wardoor het hartminutuolume zijn normale warde behoudt. In werkelijkheid gebeurt dit bij een licht hartinfarct ook. We spreken dan van een "gecompenseerde hartzwakte". Hiermee wordt bedoeld dat de hartunctie - ondanks de afgenomen concractiekracht wan de hartspier - wordt hersteld.

Als de student ingrijpt in het model kort na het tijdstip warop de contractiekracht van de hartspier met $30 \%$ verminderde, kan er een digitalistherapie worden gestart, die de overvuling van het vacscolsel kan voorkomen en door zijn primaire werking de contractiekracht van de hartspier verhoogt. Na korte tijd blijken alle model paramcers weer op hun normale warden wan voor de plotseling opgetreden hartzwakte terecht gekomen te zijn. Er is dan, bij naukeurige dosering van digitalis (DIGI \pm 0.6 eenheden), geen significante verhoogde NCFV en $B V$ en een normale rechter atrium druk (RAP $=0$ mmttg).

In figur 4.3 is het hemodynamisch effect van een zwar hart infarct nagebootst. Op het aangegeven tijdstip is de contractiekracht van de hartspier (HSB) met $70 \%$ verminderd. Het hartminuutvolume daalt veel sterker dan in het eerste geval. De reflexmatige verhoging wan de perifere weerstand en de daling van de urineproductie is onk sterker. Als hier miec therapeutisch wordt geInterveniëerd, zal cen patient met dit hemodynamisch patroon spoedig overlijden aan vergtikking welke kan optreden bij longoedeem.

Als de student ingrijpt in het model kort na het tijdstip warop de hartinsufficientie optrad en een digitalis therapie stark (DuG = 1.1E), Kan hij deze patient wrijwaren van de kans op oedeem. Een dinreticum kan hierbij nog een eventuele coename van het extracellulairc vocht reduceren.

In deze simulatie kan tenslote ook nog worder gexpertmentect met een watwerwijder (VASCON), tesamen met eem digitolls therapin"

\section{Hypertensie}

In figuir 4.4 wordt een door een renale arteriële comstricta 

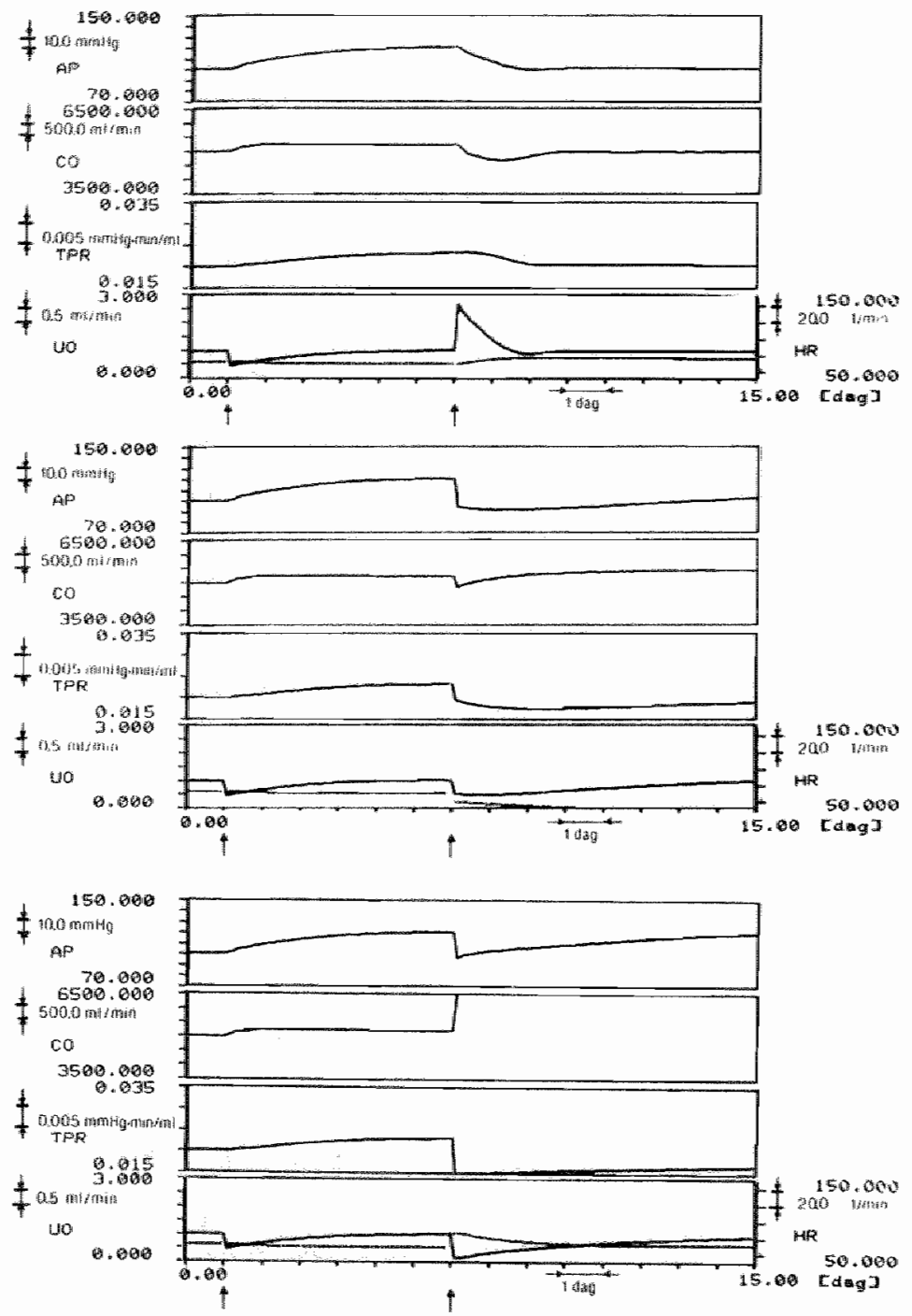

Flgur 4.4.: Casus hypertenste. Op dag 1 wordt RARB $=1.22 \mathrm{E}$. $\mathrm{Na} 6$ dagen is de geniddelde blaeddruk (AP) $120 \mathrm{mmHg}$ en de cotale perifere weerstand (TPR) verhoogd $(0.0235 \mathrm{mmlg} \cdot \mathrm{m} / \mathrm{n} / \mathrm{ml})$.

a. Diureticum therapie (DI $=0.9 \mathrm{E}$ ) geeft een normale AP en $C O$ en een tijdelijke werhoogde diurese op dag 15.

b. Sympathicolyt icum therapte (BLOCK $=0.65$ ) geeft een

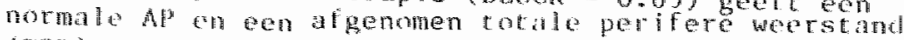
(TPR).

e. Lin vantuermijder alleen (VASCON $=0.5)$ geeli slechts 1 it 2 algen cen bloeddrukwerlaging. Tegeli jkert i jol is co langdurig verhwogd (hoger dan de ingestelde maximale warde).

Schalindeling als bij figuur 4.2. 
(RARB = 1.2E) na 7 dagen een stablele hoge bloeddruk geinitieerd. We hebben hier te maken met een simulatie van een nieratceriestenose. De excretoire functie van de nier neemt af en er treedt en vloetstofretentile op. Door het toegenomen hartminuutvolume (co) verhoogt de gemiddelde arteriële bloeddruk (AP) en via de autoregulatie wordt een werhoging van de totale perifere weerstand TPR veroorzaakt. (opt $=7$

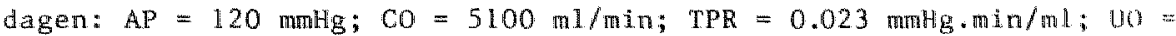
normaal; $H R=$ normaal).

De student kan deze vorm van hypertensie, veroorzakt door een arteriäLe nierstenose, met 3 ant ihypertensiva of een combinatie van dezo lyo... handelen.

\section{1. een diureticum \\ 2. een vatverwijder \\ 3. een symathicolyticum}

Door acute nierinsufficientie (renale massa (RM) verlagen tot $0.1 \mathrm{~B}$ ) of door een feochromocytoon (PHEO) kan ook hypertensie worden gesimuleerd. Deze casusbeschrifving beperkt zich echter tot een arteriële nierstenose. In het geval de student kiest voor een diureticum als antihypertensivum dient hij bij een bloeddruk van $120 \mathrm{mmHg}$ (norm: $100 \mathrm{mmHg}$ ) te kiezen voor DI = 1 .OE, wardoor de patient na ongeveer 2 dagen weer normotensief wordt $(\mathrm{AP}=100 \mathrm{mmHg})$.

In het geval de keus gemaakt wordt voor een watverwijder, die niet op de niler werkt, is $0.15 \mathrm{E}$ voldoende om de bloeddruk (VASCON $=0.15 \mathrm{E}$ ) enkele dagen normal ce houden $(A P=100 \mathrm{mmHg})$. Het hartminuuvolume is hierbij verhoogd. Het leidt echter niet tot een permanente bloeddrukdaling. Bij een sympathicolyticum als antihypertensivum is $0.65 \mathrm{l}$ woldoende om de bloeddruk na 7 dagen normal te laten worden (BLOCK $=0.65 E$ ). Het hartminutuolume is hierbij wel sterk verhoogd $(\mathrm{CO}=5400 \mathrm{ml} / \mathrm{min})$.

In de appendices wordt een reeks voorbeelden van casussen gegeven zoals die in het kader van diverse blokken aan de studenten worden angeboden.

Discussie

Het model van CARDIO is als een van de eerste, naast AORTA, geimplemenceerd in het RL-computerstimulatiesysteem. Met dit simulatieprogramma 
is ervaring in enkele blokken opgedaan $m . n$. in de keuzeblokken farmacologie en hart en longen, in het blok mooheid (3.2.) en in het blok pijn op de borst (3.3). Er is door diverse medewerkers, watronder studentassistenten casulstiek ontwikkeld, waaronder casus m.b.t. een hartinfarct, hypertensie en therapieen bij diverst a andoentigen. Het op deze manier presenteren van een taak in de vorm van een pat iêntencasus is noodzakelijk gebleken om in de 2 uur dat studenten, gemiddeld, in een blok een computersimulatieprogramma gebruiken, zil. of hoogutt 2 problemen goed aan de orde kumen stellan. De casus licht en zwar hartinfarct geeft meestal anleiding om daarna of tijdens de loop van het programma na te kijken hoe het lichaam een hartinsufficientie kan compenseren door vocht wast te houden. Indien de diglcalis therapie ontbreekt of anvoldoende is, loopt de student het risico te maken te krijgen met de melding dat zijn patient op een zeker moment "last van dikke voeten" krijgt.

De casus hypertemsie geeft de student vaak aanleiding om werkingsmechanismen vam ant thypertensiva nader te bestuderen. Belangrijk bij deze casus is voor de studenten ook het leren ongaan met enige aspecten van dosiswerkingsrelaties bij antihypertensiva en dat vaatverwijders chronisch niet als een monotheraple kunnen functioneren bij hypertenste. Het computersimulatieprogramma CARDIO heeft verschillende versies gekend. Met name bij de twee-terminal versies is veel geëxperimenteerd met het computersimulatiesysteem on te bestuderen hoe het systeem bij de studenten overkwam en om te kijken waar knelpunten lagen. Met het computersimulat leprograma CARDIo is ook veel geëxperimenteerd en het is frequent aan externe en interne deskundigen gedemonstreerd on discussies en adviezen over de opzet van het systeem te verkrijgen (Min et al., 1981).

Het programa is door meer dan vijftig studenten in 6 periodes vanaf mei 1980 gebrutkt.

In de appendices 4.4 . $t / m 4.7$ wordt de casuistiek getoond zoals in het studiejar $1981 / 1982$ in het onderwijs werd gepresenteerd. 
Coleman, T.G., R.D. Manning, R.A. Morman Jr., A.C. Guyton, Contral of cardiac output by regional blood flow distribution. Ann. Biomed.Eng. 2, $149(1974)$.

Coleman, T.G.,

Computer analysis of averall control of the curculation. Internal paper; Dept. Physiol. Bloph., University of Mississippl (1977).

Coleman, T.G.

A mathematical model of the human body in health, disease, and during treatment. Proc. Joint Automatic Control Conference 4,77 $(1978)$.

Coleman, T.G.,

Notes on a mathematical model of overall control of the circulation.

Internal paper, Dept. Physiol. Bioph., University of Mississippi $(1979)$.

Guyton, A.C., T.G. Coleman, H.J. Granger,

Circulation: overall regulation. Ann.Rev.Physiol. 34,13 (1972).

Guyton, A.C., T.G. Coleman, A.W. Cowley Jr., R.D. Manning Jr.,

A system analys is approach to understanding long-range arterial

blood pressure control and hypertension. Circ.Res. 35, 159 (1974).

Guyton, A.C.,

MACMAN

Computer simulation of heart and blood circulation. Manual McMascers

Universicy, Hamilton (1976).

Min, F.B.M., H. van Kan, H.A.J. Struyker Bowdier,

Computer simulation programs in problem oriented medical learning

at the University of Limburg. Symposium on Computer Assisted

Learning (1981), Leeds (Ed. P.R. Smith). Comput. Educ. 6, 153 (1982).

Struyker Boudier, H.A.J., K.H. Rahn,

Systeemanalyse van de bloeddrukregulatie; het sympathische zenuw-

stelse1 en hypertensie. Ned.T.Geneesk. 123, 860 (1979).

\section{Literaturlijst}

Boyers, D.G., J.G. Cuthbertson, J.A. Luetscher,

Simulation of the human cardiovascular system: a model. with mormal

responses to change posture, blood loss, transfuston, and automonic

blockade. Simulation 6, $197(1972)$.

Gordon, M.S., A. Gordon, A.C. Deleon, R.A. Wagh, J.M. Felner,

A.D. Forker, I.H. Gessner, J.W. Mayer, D. Patterson,

"Harvey", the cardology patient simulator: pilot stucties on

teaching effectiveness. Am.J.Cardilol. 45, 79l (1980).

Green, J.F., A.P. Jackman,

A simulation study of transient changes in splanchnic and peripheral

blood flows in the dog after a wollume load. Ann. Bioned. ling. 3. 315

$(1975)$.

Guyton, A.C., A.W. Crowley Jr.,

Cardiovascular phystology $1 \mathrm{i}$. (Intermational review of Physilology a).

Univ. Park Pross, Balt inore $(1976)$.

Hownki, N.,

A simulation study ar cormary arculatory system - a theoretical andysis of intramyocardial flow distribution mechanism. Jpo.circ... 4. $1299(1977)$.

Johinson, D.C.,

A program to teach and demonstrate cardlovascular control through

simulation. Physiologist 16, 636 (1973). 
KAtrent, R.I.

A nonlinear model for studying ascillations in the blood pressure control system. J.Blomed. Eng. 1, 89 (1979).

Laxminarayan, S., P. Sipkema, N. Westerhof,

Characterization of the arterial system in the time domain. IEEETrans. Biomed.Eng. 25, $177(1978)$.

Levy, M.M., H. Zleske,

Factortal analysis of the cardiovascular responses to carotid

sinus nerve stimulation. Ann.Biomed. Eng. $4,111(1976)$.

Luczak, H., Fischke,

Regelungstheoretisches Kreislaufmodell zur Interpretation arbeitsphyslologischer und rhythnologischer Einflusse auf die Momentanherzfrequenz: Arrhythmie, Biol, Cybern. 18, 1 (1975).

M11er, C.E., S. Thompson, J. Lozar,

A theoretical evaluation of cardiac output as a function of mean arterial pressure in the humen cardiovascular system. J. Theor. Biol. 63, 89(1976).

Ruigt, G.S.F., M. Woerlee,

Een model van de regeling en de dynamica van de vochtopma bij de mens; aanpassing van de wochtballansregeling van een computermodel van de blloedcirculatie. Rijksunlversiteit Utrecht, Vakgroep theoretische biologje, Utrecht (1978).

Sagawa, K.,

Critlque of a large-scale organ system model: Guytonian cardiovascular model. Ann. Biomed.Eng, 3, 386 (1975).

Sato, I., Y. Hasegawa, K. Hotta,

System analys fs of heart rate control in man. J.Appl.Physiol. 41 , $790(1.976)$.

Sato, T., M. Shotrataka, N. Ikeda, F.S. Grodins,

Steady-state systems analysis of hepatic hemodynamics in the

isollated perfused canine liver. Am.J.Physiol. 233, RI88 (1977).

Struyker Boudifer, H.A.J. (Red),

Regulatie van de bloeddruk. Wetenschappelijke Uitgeverij Bunge,

Utrecht (1979). 
HOOFDSTUK 5

Computersimulatieprogramma fLUTOS

Onderwijskundig doel

Het computersimulatieprograma FLULDS stelt studenten in staat te experimenteren met een model van de water- en electroliethuishouding en de regulatie van de ademhaling en de daaraan ten grondslag liggende fyslologie en pathofysiologie. Het bestaat uit de compartimenten: hart- en vaatselsel, longen, intra- en extracellulaire vloeistofruintes, zenuwreflexen, de nier en een aantal hormoonsystemen met een invloed op de nierfunctie. In sommige opzichten valt het samen met het model CARDIo, maar het is op belangrijke onderdelen veel uitgebreider. Het programma simuleert ook een experimentele laboratoriumomgeving, zodat onderzoek kan worden verticht naar de water-en zouthuishouding en de regulatie van de ademhaling onder allerlei omstandigheden. studenten hebben als het ware de beschikking over een proefpersoon, warbij ze een hele serie experimenten kunnen doen. Zo kan b.w. langdurig dorsten, zweten of excessief water - of zoutverlies worden nagebootst. Ook kan een verandering in de zuurstof of kooldioxidefraktie in de inademingslucht worden nageboatst. Verder kunnen stoornissen in de zuur-base-evenwichten en de nierfunctie worden gesimuleerd. Naast deze ziek-makende ingrepen zijn therapeutische handelingen mogelijk, b.v. aanleggen van infusen van diwerse samenstellingen, het laten inademen van extra zuurstof of het toedienen van een diureticum. Betreffende de glucasehuishouding is het mogel $1 \mathrm{jk}$ eem glucosecolerantietest uit te voeren. Ondanks de complexitueit van thet model vinden studencen gemakkelijk hun weg in dit simulatieprogramma. Het accent $11 \mathrm{gt}$ op de vrije exercitie met dit programa om op die manter al doende gevoel te ontwikkelen voor de wijze warap dit complexe fysiologisch dynanisch systeem werkt.

Model van de water- en electroliethuishouding

Het model van het computersimulatieprograna flumbs is een model van de water - en electroliethishouding van en gezonde mannelijke person van $55 \mathrm{~kg}$. Het model van de regulat le van de lichaamswloeistoffen is ontworpen door Ikeda. Marumo. Shiratako en Sato in 1979 en bouw voorl op publicaties en modellen van o.a. Guytor (1972) en Blaine (1972) 
(Blafine, 1972; Guyton et al.,1972; lkeda et al.,1979).

Er zijn door ons 3 modellen m. b. de electrollethuishouding onderzacht op hun geschiktheid in het onderwijs; het model van Guyton er a1.(1972), MACPEE en PACPUP wat Dickinson et a1.(1972). Her model van Guyton et al. kent een uitgebreid cardiovasculair systeem mec gedetailleerde beschrijving van de microcirculatoire dynarica, hetgeen bij het model van lkeda zeer minlmal is gehouden. Howel het model wan Guyton blokken bevat war de extracellulaire natrium- en kalifumconcentraties berekend worden als functle van de innane van natrium en kalium, de renal excretie, do aldosteronconcentratie, de hoeveelheid gedronken vloeistof en het plasmavollume leek het model van Ikeda iets geavanceerder. Cuyton's model bevat overtigens meer aspecten van lkeda's model, maar is voor de studenten moellijker toegankelıjk (Guyton et a1., 1972; Guyton, 1976).

Het model. van het computersimulatieprograma MACPEE van Dickinson th al. heef $t$ een goed subsysteem voor wat de nierfunctie betreft. Er is rekening gehouden met de wher- en elwthulshouding, urine-excretie, voedse1opname en een ureum- en reninesysteem (handleiding MACPEE, 1978). Het model wan het computersimulatieprograma MACPUF van Dickinson et al. is zeer uitgebreid en wordt elders veel gebruikt in het onderwijs. Het is een van de best gedocumenteerde computersimulatieprograma's die bestaan (handleiding MACPUH, 1977; Dickinson et al.,1977). De experi.menten die men met MACPuF kan uttvoeren liggen op het terrein van effecten die verschillende niveaus van wentilatie kunnen hebben op de gehalces van de ademhalingsgassen in het bloed; van effecten die een kuristmatige shunt hebben; van effecten bij veranderende $\mathrm{O}_{2}$ en $\mathrm{CO}_{2}$ verhotdingen lin de thadeningslucht; van efecten die inspanning met zich mex. brengt; van effecten op extreem hoge inspanning (Dickinson 1972; Dickinson et a 1.,1979). Ook anderen hebben zich met dit soort modellen, o.a. Sato (1976) en MHhorn (1976) bezig gehouden (Forster, 1970; Bergman,1977; Cobe 1. i. 1982). Wif widen echter vrijheid tot weranderen van het model en hebben darom gekozen voor het model van lkeda et al. Het model van lkeda bostant wit de volgende subsystemen: de circulatle, de ademaling, de nierfuntele en de incer-en extracellulatre viodstofcompartimenten. Hot besitat wit 30 dutegralvergel jakingen plus andere algebratische vergelijkingen. In total bevalt het ruim 270 variabelen. De water en zouthtishouding kent een groot verschil tussen verschillende individuen en ook tussen de geslachten. Toch kan er gesproken worden van normaal- 

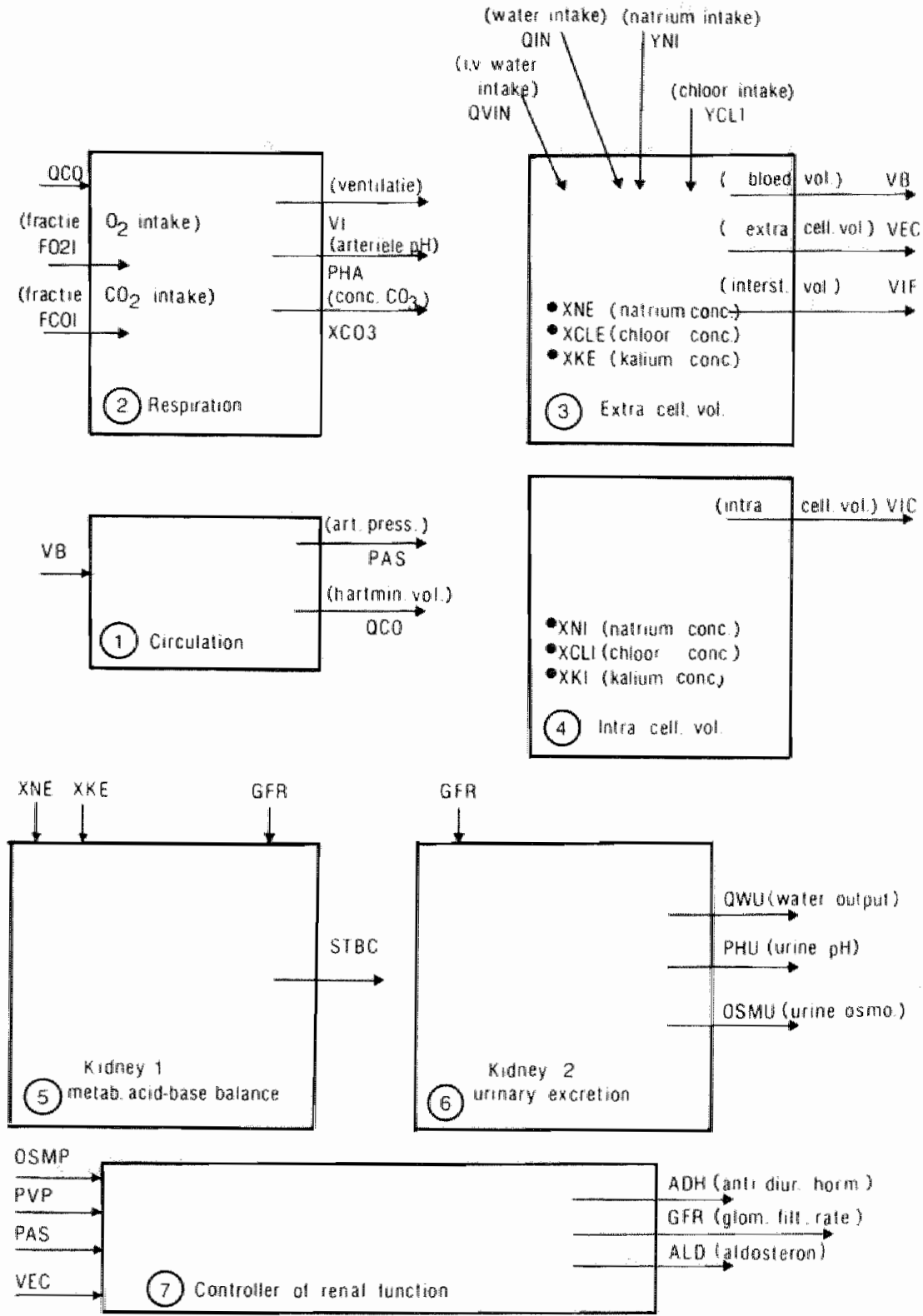

Figuur 5.1: Blokschema van het model van lkeda et al. van de water- fin electroliethuishouding. De pijlen die de blokken binnen gaan $z$ ijn interventiemogelijkheden, de piflen die de rand van de blokken raken zijn ingangsvariabelen en pijlen dic de blakken verlaten $z$ ij uitgangsvarlabelen. Zic voor or verklaring van de modelgrootheden de appendices 5.2 en 5.1. 


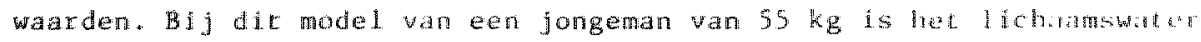

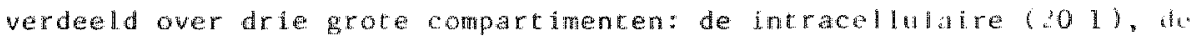

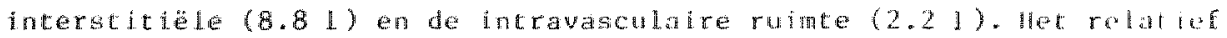
geringe transellulabe water (hersenvocht, wowt in magdarmanal, oogkamervocht, gynovialvoche e.d.) is buiten beschouwing ge laten win

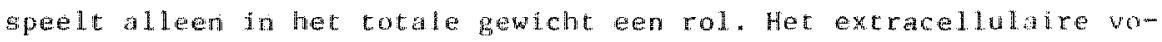
lume is 11.1 en het bloedvolume 4 1. De samenselling wan het bloed-

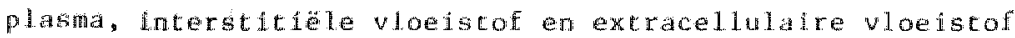
voor wat betreft de opgeloste geioniseerde stofien en de moleculaire opgeloste stoffen of gassen, Ls zeer specifiek (Reed en Sheppard,1977). De samenstoling ls gegeven in tabel 5.1 .

Tabe 1. 5. D: De normale warden van fonenconcentraties e. A. in het ant racellulaire en intracellulaire vioeistofcompart inent in lnt

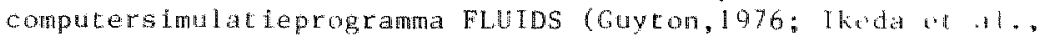
1.979).

Eixtracel lullatre concentraties:

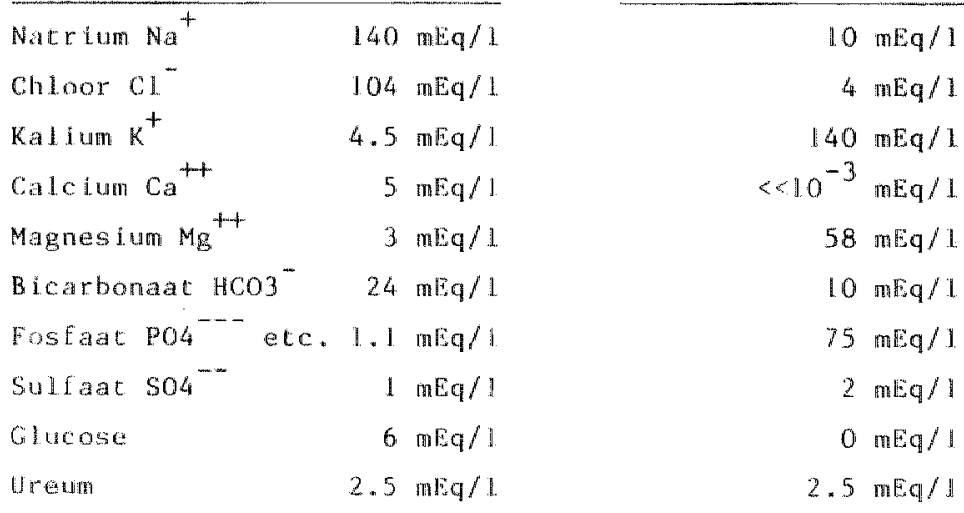

Lir 2 In tal van regelmechanismen om veranderingen van de concontrat ios in het axta- en intracellula tre vloejstofcompartiment zo klein mogeL.jk te houden. Een belangrijke rol hierbij speelt de nier, die het voLume en de colloid osmotische druk van woeistofruimten regelt. Darnast is er ook een tegelmechanisme woor de zurgrad, voor de stabilisering van de bloedgasspaning van $\mathrm{O}_{2}$ en $\mathrm{CO}_{2}$, voor de stablisering vart de ionensamenstelling en voor de stablitsering van het glucosegahalte (Reed en Sheppard, 1977; Bernards en Bonman, 1979; Sinth, 1980). Het model kent 7 te onderscheiden delen wartussen relaties bestan 20 as ln figur 5.1 in grote 1 jmen is a angegeven. In deze figuur zijn ook 
enkele interventies, die mogelijk zijn in dit model, aangegeven. Zie ook appendix 5.2 voor een overzicht van belangrijke interventies.

1. Cardiovasculain systeem. Het cardiovasculalre systeen is teruggebracht tot een minimal noodzakelijk functionele eenheid voor het hartminuutvolume en de gemiddelde arteriële bloeddruk die in dit model slechts afhangen van het bloedwolume, de elasticiteit van het vaatstelsel en perifere vaatweerstand. Doordat dit cardiovasculaire deel zo minimal is (gehouden), kunnen simulaties van cardiovasculaire andoeningen bij dit model moeilijk worden witgevoerd.

2. Ademhlimgssteen. Het regelsysteem van de ademhaling is bij dit model een functionele eenlid warbij de ventilatie afhangt van de pll, de $\mathrm{CO}_{2}$ - en de $\mathrm{O}_{2}$-spaning in het arteriële bloed. De pH van het bloed wordt bepald door het gehalte aan vrij opgeloste $\mathrm{CO}_{2}$ en het gehalte aan $\mathrm{HCO}_{3}^{-}$. Hierbij geldt de vergelijking van Henderson-Hasselbalch. Het hemoglobine buf fersysteem $k$ an door opnemen of afgeven van $H^{*}$-ioner de $\mathrm{pH}$ van het bloed constant houden ondanks dat ex situaties a ijn war een grate of snelle verhoging of vermindering van $\mathrm{H}^{+}$-ionen platsvindt. De $\mathrm{pH}$ in het bloed wordt in belangrijke mate bepald door aminozuren waaruit eiwitten $z \mathbb{1} j n$ opgebouwd. Dit buffersysteem van $\mathrm{H}^{+}-1$ ionen reguleert de $\mathrm{pH}$ rond 7.4 (iso-electrisch punt). Een ander buffersysteem voor de $\mathrm{pH}$ is de bicarbonatbuffer. Voor het goed functioneren van dit systeem dient wel het $\mathrm{CO}_{2}$ overschot goed te worden afgevoerd via de longen.

3. Extracellulaire otoeistofompartiment. Tr. dit deel van het model wordt met name de regulatie van de vloeistofvolumina gesimuleerd. De opgeloste lonenconcentratie in het extracellulaire vloeistofcompartio ment hangt ten nauwste samen met de hoeveelheid water die het Ifcham opneemt en weer uitscheidt. Het vloeistofvolume in het extracellulat o compartiment wordt bepald door de hoeveelheid water die oranl of intraveneus wordt toegediend en door het verlies an wloelstol vit de urine en zweet. Voor de concentraties van de opgeloste stoffen geldt dat inname hiervan meestal via het voedsel en het magdarmkanal tot stand kont. Ook intraveneuze toedienting per infuus is in dit model mogejijk. Bij dit model zijn alle intamen gemiddeld over 24 uur genormaliseerd op bepealde referentiewarden per minut.

4. Intracellulatre vloevtofompart iment en electrolieten. In dit deel van het model heeft Ikeda et al. het intracellulatre vloeistof- 
volume, de osmotische actleve stoffen in de intra- en extracellulaire rutiten en de Intracellulalre zuur-base balans ondergebracht o.a. natrlum, kallum, chloor, glucose, ureum en mannitol. De werandering in de extracellulatre natrium hoeveelheid (ZNE) wordt door rkeda et al. als volgt gesteld:

$d(Z N E) / d t=1$ nname van Na (YNIN) -excretie van $\mathbb{N a}$ (YNU) troename van $\mathrm{Na}$, in ruil voor $\mathrm{H}^{\mathrm{H}}$-ionen de cel in.

en de werandering van de kalüum hoeveelheid in de extracellulatre ruimte (ZKE) als volgt:

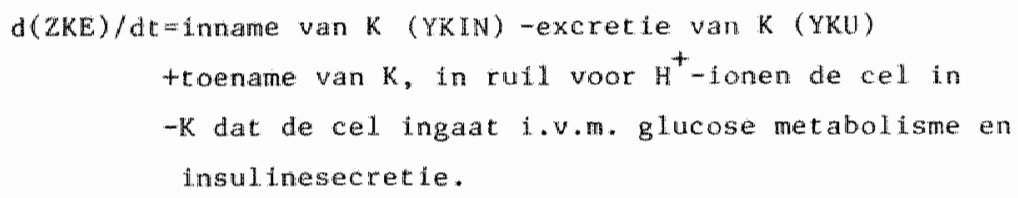

Het ureum reabsorptiemechanisme in dit model is passief warbij is aangenomen dat ongeveer $60 \%$ van de gefiltreerde hoeveelheid uiteindell ijk wordt uitgeschelden. De plasma osmolaliteit (OSMP) wordt in het mode) afhankelijk gesteld van de natritum, kalium, chloor, glucose, wreum en menttol concentraties, alsmede een constante factor voor de overige osmotisch actieve stoffen.

$5 / 6 / 7$. De nier. De renale ultschelding voor bicarbonat, calcium, magnesium, fosfaat en organische zuren $z 1 j n$ in dit model functies van de glomerulaire flltratiesnelheid en de concentraties van deze ionen. In de glomerulus wordt langs fysische weg een hoeveelheid vocht uit het plasma gefiltreerd. De bloeddruk is in dit model de drijuende kracht. In de peritubulaire capillaten komt darna, selectief, het grootste deel van thet filtrat weer in het plasma. Het kalium-en natriumtransport is actlef, het gat zowel tegen de concentratiegradient als de electrische gradtënt in. De negatieve Lonen zoals chloor diffunderen passief, behalve het bicarbonat. Het transport van water vindt alleen plaats als ar een osmotische drijvende kracht is. Het model tracht de osmolalitelt van het plasma en de urine constant te houden. Hlepblj spellen chemoreceptoren een belangrijke rol. Het akt leve transport vin ionen en het transpott van water staat onder invloed wan hormonen. In dit model wordt het aktieve natriumtransport bevorderd door aldosteron dat daarmee natuium wasthoudt (reabsorbeert) en kalium ultscheidt. De uitscheiding van water kan worden geremd door het ant $j-$ diuretisch hormoon. 
Het model dat aan het computersimulatieprogramma FLULD ten grondslag ligt is ontworpen door Ikeda en medewerkers in 1979. Dit model is niet in eerste instantie gemaakt t.b.w. het onderwijs, maar voor onderzoek. Hier wordt volstaan met de beschrijuing van de meest essentiële onderdelen uit de verschillende blokken. De volledige listing wordt gegovon in appendix 5.6 .

\section{De circulatie}

Het harcminuutvolume (QCO) is slechts afhankeli $\mathrm{jlk}$ van het bloedvolume (BV) en bepaalt samen met de totale perifere weerstand (RTOT) de gemiddelde arteriele bloeddruk (PAS). In ForTRAN ziet dit deel van het model er als volgt uit:

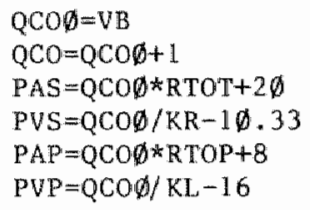

De analoge notatiewijze is:

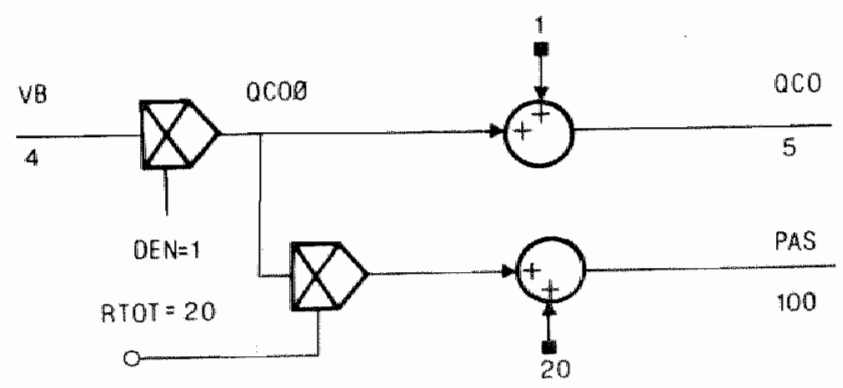

\section{De vloeistofvolumina}

Het plasmavolume (VP) wordt bepald door de hoeveelheid water die intraveneus wordt toegediend (QVIN), de hoeveelheid die oraal door het lichaam wordt opgenomen ( $Q \mathrm{IN})$, de hoeveelheld water die het lichan verlaat wia de urine (QWU) en o.a. nog door de hoeveelheid water die door zweten het lichaan verlaat (QIWL) en dat wat metabool gevormd wordt (QMWP). 
De analoge notatlewijze is als volgt:

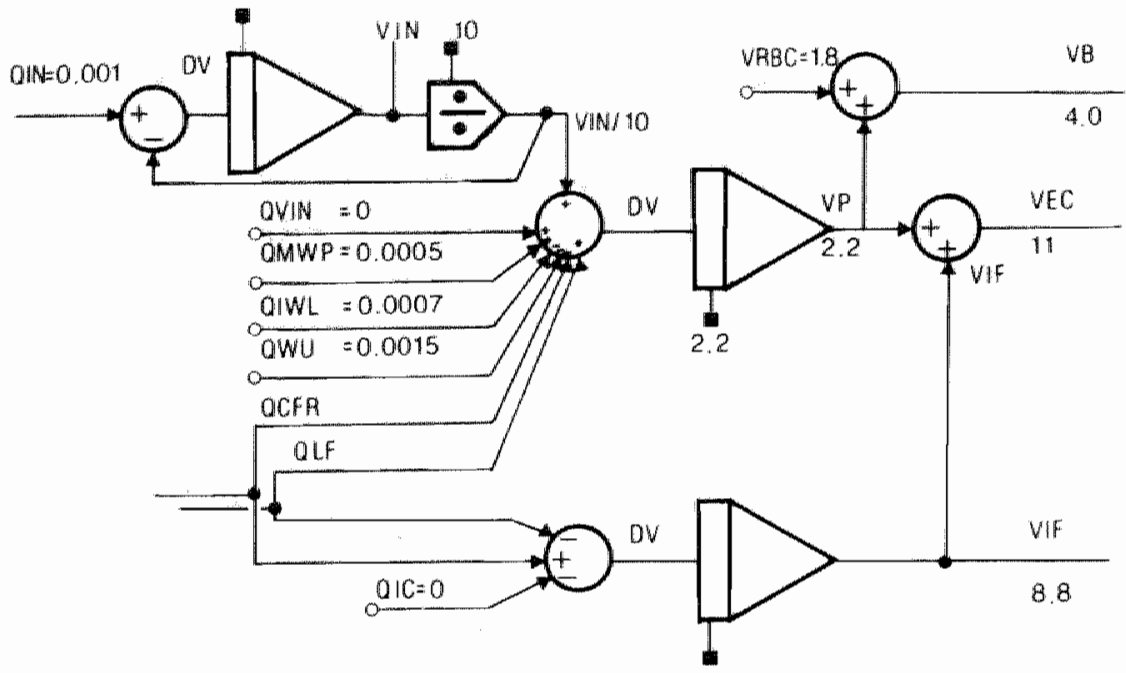

8.8

en in FORTRAN:

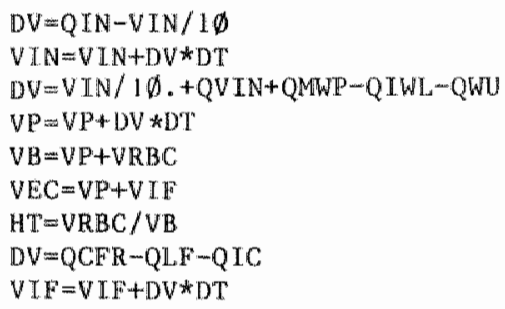

Wh het plasmavolume wordt uiteindelijk het bloedvolume (VB) en het extracelindalr vloeistofvolume (VEC) bepaald. Het interstitiéel vloeistofvolume (VIF) wordt op soortgelljke wijze berekend.

\section{De matrium - kal lum en chloorconcentraties}

De natrimconcentrate in de extracellulaire vloelstof (XWE) hangt af van de howeelheid water in het extracellulaire compartiment (VEC) en de absolute hoeverelheld natriur (ZNE). De absolute hoeveelheid natrlum is o.a. een functle van de gemiddelde dagelijkse natrium opmame (YNM) en de hoeveetheid die het licham via de urine verlat (YNu). Voor kalium (XKE, ZKE, YKIN, YKU) en chioor (XCLE, ZCLE, YCLI, YCLU) geldt: hetzelfde. 
Het analoge schema is:
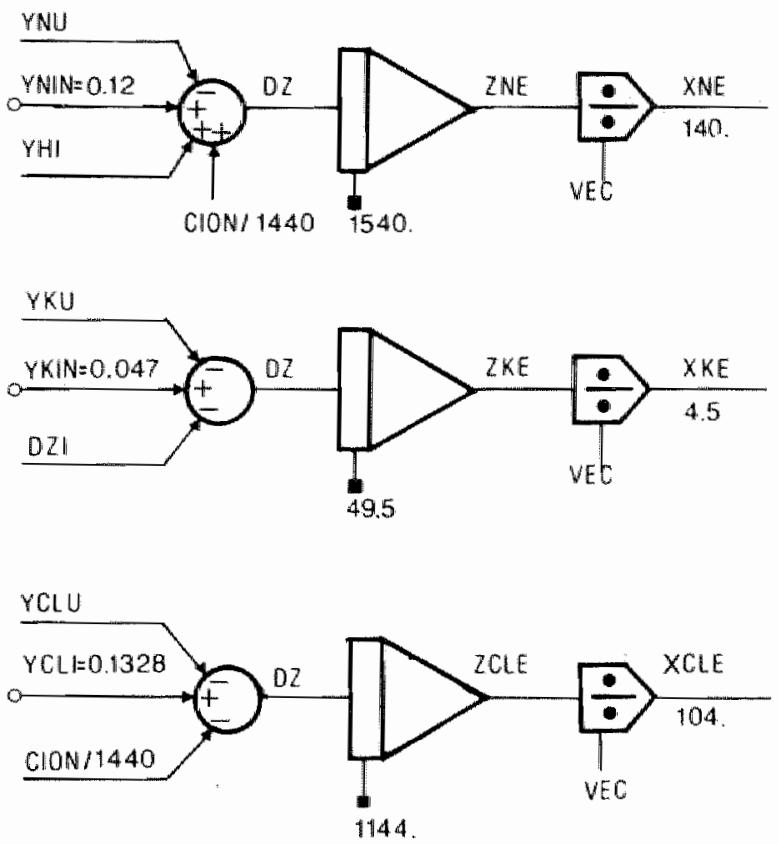

In FORTRAN:

$D Z=Y N I N-Y N U+Y H I+C I O N / 1440$

$\mathrm{ZNE}=\mathrm{ZNE}+\mathrm{DZ} * \mathrm{DT}$

$\mathrm{XNE}=\mathrm{ZNE} / \mathrm{VEC}$

en

$D Z=Y K I N-Y K U-D Z T$

$Z K E=Z K E+D Z * D T$

XKE $=Z K E$. VEC

en

\section{$\mathrm{DZ}=\mathrm{YCL} I-Y \mathrm{YCL}+\mathrm{CION} / 1.440$ \\ $Z C L E=Z C L E+D Z * D T$ \\ XCLE $=$ ZCLE/VEC}

Het model is ook zo apgebound voor calclum, magenestum, glucose, bicarbonat, fosfat, sulfaat, ureum, mamitol, andere organische zuren en eiwitten.

De standard bicarbonat concentratle bij pH=7.4 (STBC) wordt in dit model gedefinieerd als het verschil van de concentraties kat lonen en anionen (in het ECF), arders dan die van bicarbonat. 


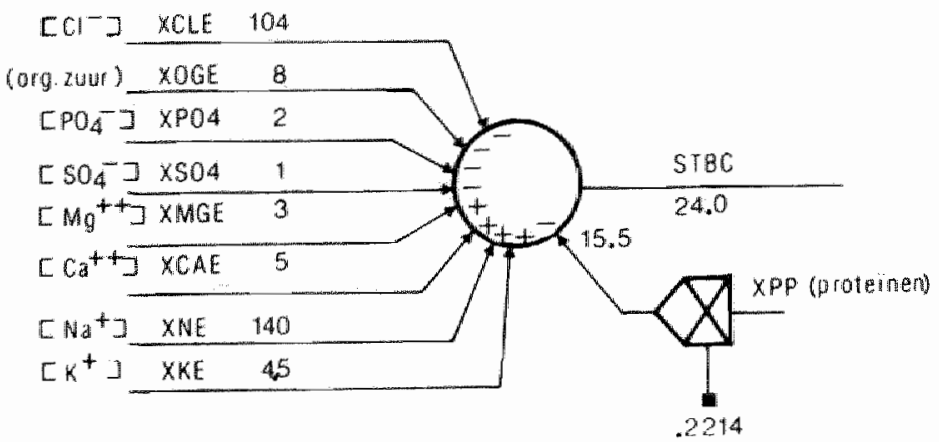

\section{Wier en urine}

Des osmolaliteit van de urine (OSMU) wordt bepald door de urine-output (QwU), de glomerulaite filtratesnelheid (GFR) en het antidiuretisch hormoon $(A D H)$.

Het analloge schema:

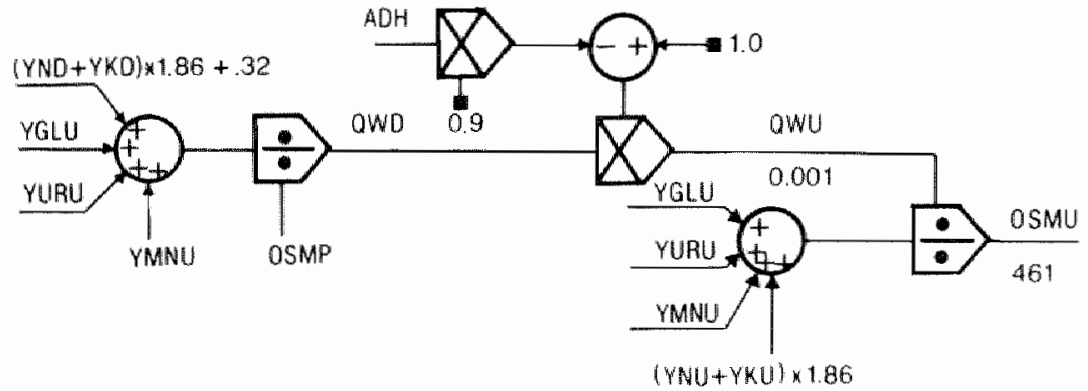

In FORTRAN:

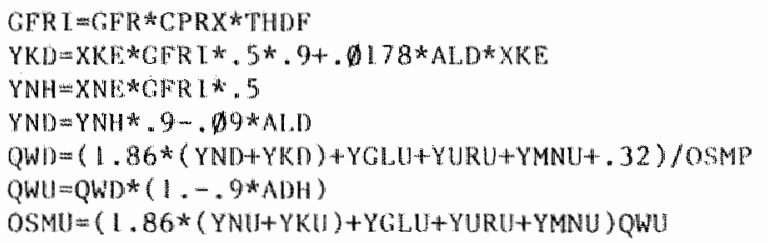

De pH van de urine (PHU) wordt berekend uit o.a. de renale klaringssimelheid van organische zouten (YORG) en de renale klaringssnclheid van fosfaat (YPO4). 


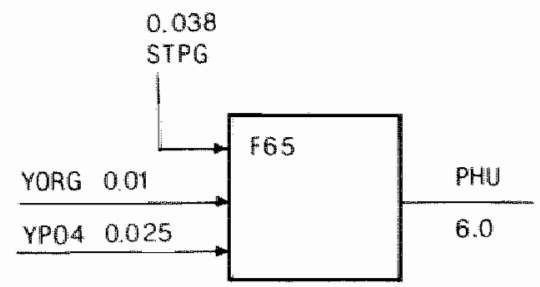

In FORTRAN :

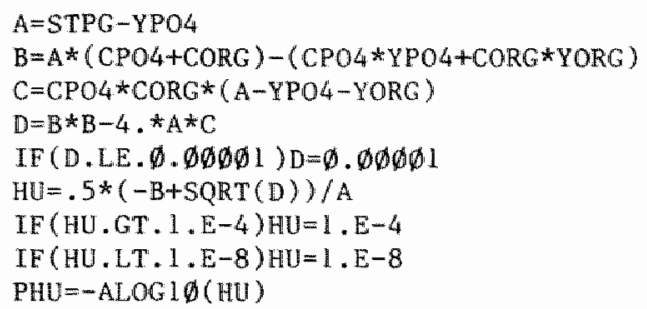

\section{De_glomerulaire filtratiesnelheid}

De glomerulaire filtratiesnelheid (GF) is hier slechts een functie van de gemiddelde arteriële bloeddruk (PAS) en het extracellulaire wloeistofvolume (VEC).

Analoge schema:

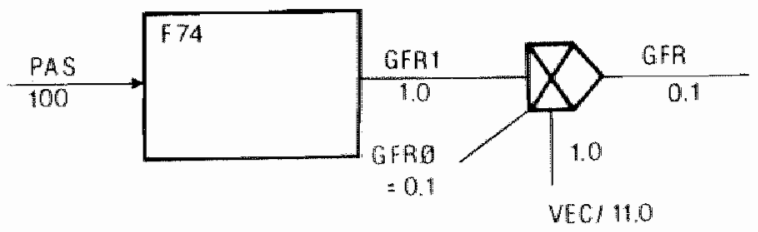

In FORTRAN :

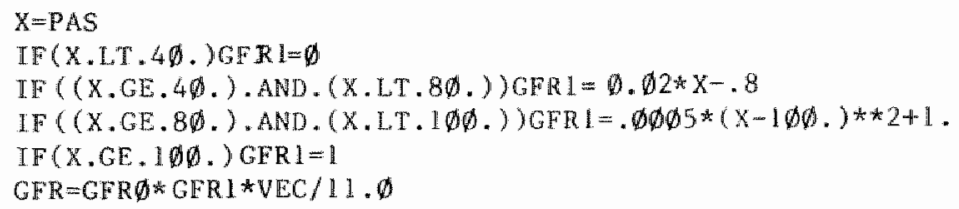

De ademhaling

De ventilatie (VI) wordt bepaald door de CO2-druk (PCOA), de 02-druk (PO2A) en de pH van het arteriële bloed (PHA). 
De $\mathrm{pH}$ in het arteriele bloed (of in de alveoli) (PHA) wordt berekend via de Henderson-Hasselbalch vergelijking:

$$
p H=p K+\frac{\left[\log _{0}^{-}\right]}{s_{.} p_{\operatorname{co} 2}}
$$

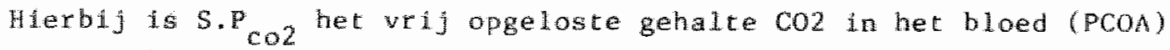
en $\left\{\mathrm{HCO}_{3}{ }^{-}\right.$] het gehalte $\mathrm{HCO}_{3}{ }^{-}$in het bloed (xCO3).

De analoge notatiewijze is:

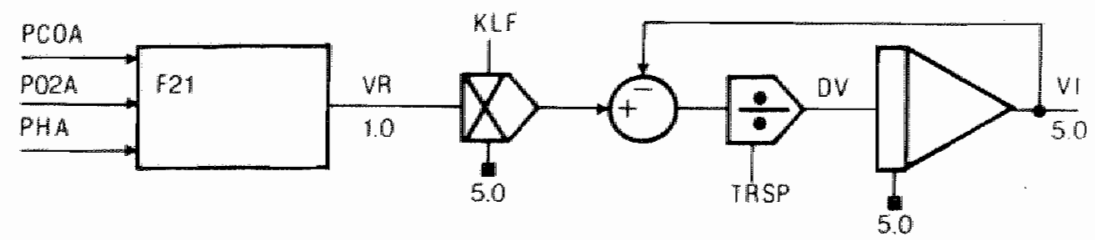

En in FORTRAN:

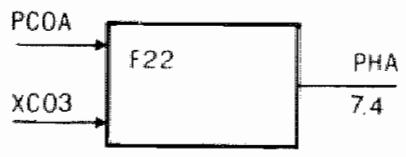

IF (PO2A.LT. 33.) PO2A $=33$

$\mathrm{VR}=.22 * 1 \emptyset . *(9 .-\mathrm{PHA})+.262 * 32 .-18.238$

$*+.2125 *(1 .+17 . /(P O 2 A-32)) *,(P C O A-32$.

IF (VR.L.E. $\emptyset.) \cup R=\emptyset . \emptyset 2$

$\mathrm{DV}=(5.0 * V R * \mathrm{KLF}-\mathrm{VI}) / \mathrm{TRSP}$

$\mathrm{VJ}=\mathrm{VI}+\mathrm{DV} * \mathrm{DT}$

$\mathrm{PHAA}=\mathrm{XCO} 3 /(.03 * \mathrm{PCOA})$

$\mathrm{PHA}=6.1+\mathrm{ALOG} 1 \emptyset$ (PHAA) 
Resultaten

Het computersimulatieprograma FuUids meet en registreert in zijn uitgangspositie 8 belangrijke variabelen.

1. QWU Urine output

2. VEC Extracellulair volume

3. OSMP Osmolaliteit in het plasma

4. PAS Gemiddelde arterielle bloeddruk

5. VP Plasmavolume

6. VIC Intracellulaire volume

7. WIF Interstitieel volume

8. STBC Standaard bicarbonat bij $\mathrm{pH}=7.4$
$0.00151 / \mathrm{min}$

11 inter

$287 \mathrm{mosm} / 1$

$100 \mathrm{mmHg}$

2.2 liter

11.0 liter

8.8 liter

$24 \mathrm{mEq} / \mathrm{l}$

Bij deze warden geldt wel dat er geen enkele interventie in het model heef platsgevonden en er sprake is van een steady state. In de hier beschreven casuīstiek m.b.t. dorsten, zweten, drinken en infusen spelen vaak andere variabelen een belangrijke rol en het is dan ook mogelijk om bij elke casus maximaal 8 andere, willekeurige variabelen te meten en te registreren. Indien enkele wan deze variabelem boven of onder een kritische warde komen zoals aangegeven in tabel 5.2, worden de studenten door een bericht daarop geattendeerd.

\section{Dorsten}

Een belangrijke simulatie is de proefpersoon (c.q. het model) gedurende lange tijd water te onthouden. Daartoe kan de waterinname (QIN) die normaal 0.0015 liter/min (dat overeenkont met $90 \mathrm{ml} / \mathrm{uur}$ ) is tot 0 worden gereduceerd (zie casus 5 en 6; appendix 5.4, taak 1).

In figuur 5.2 is te zien dat het plasma volume (VP) en het extracellulair volume (VEC) langzaam minder worden. De kalium- en natriumconcentraties worden constant door een stijging van het antidiuretisch hormoon (ADH) waardoor de nier vocht gaat vasthouden en de urinepromductie (QWU) afneemt. De osmolaliteft van de urine (OSMU) neent dus toe.

Dorsten, zweten en zoutverlies

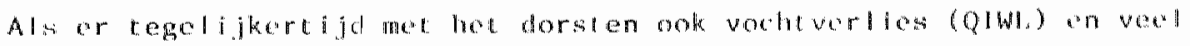

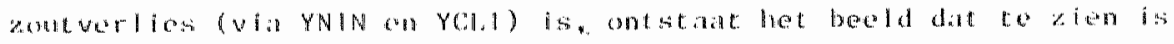

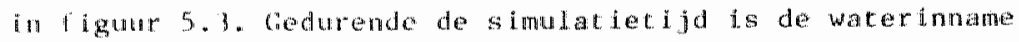

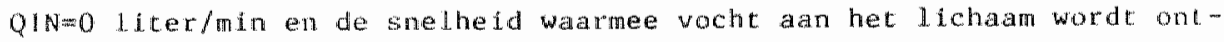
trokken (QTWL) toegenomen van 0.0007 liter/min tot 0.008 iter/min 
Tabel 5.2: Lijst met symptomen die voorkomen in het computersimulatieprograma FLulDS. Aangegeven is boven en onder wellke warde cen wariabele moet komen on een slgnal c. $q$. boodschap te kunnen geven naar de stident toe.

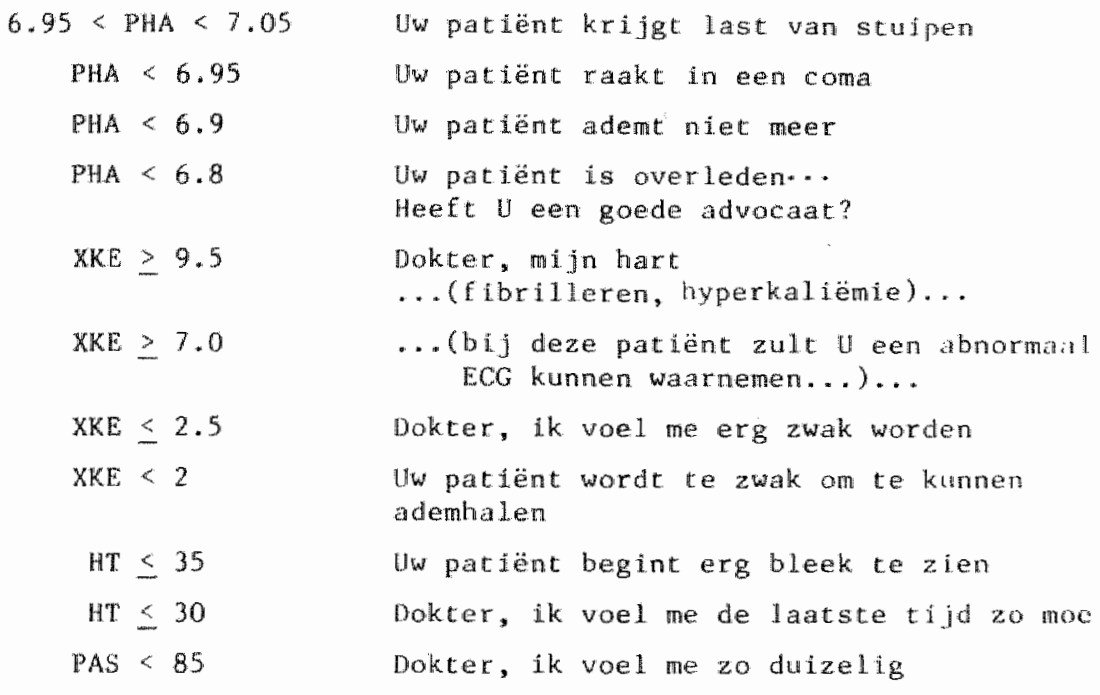

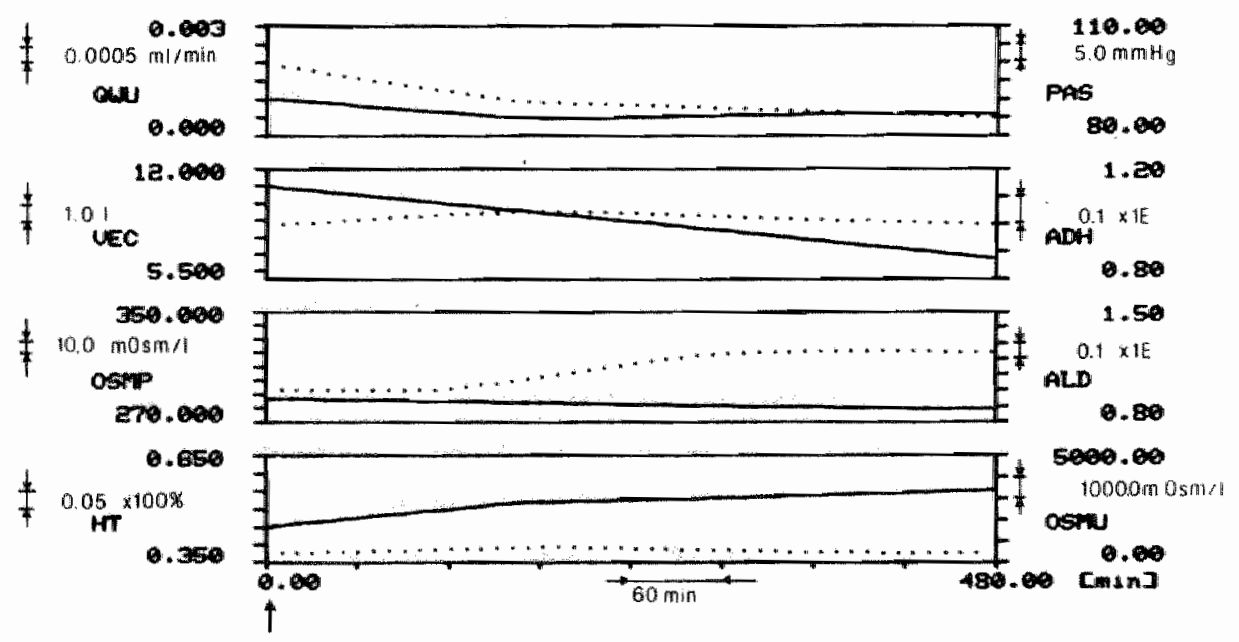

Figuur 5.2 Dorsten gedurende 8 ur $(Q \mathbb{N})=01 / \mathrm{min})$. Schalinstelling: t-as van $0 \mathrm{c} / \mathrm{m} 8$ uur De warlabelen die links vermeld staan langs de y-assen behoren bij de ononderbroken geregistreerde grafieken en de variabelen die rechts. vermeld stan bij de gestippeld geregistreerde grafleken. De namen van de variabelen wordem o.a. in appendix 5.3 verklaard. 
(dat overeenkomt met 0.5 liter/uur). De natrium- en chloorimame (YNIN en YCLI) die normaal 0.12 resp. $0.133 \mathrm{mEq} / \mathrm{min}$ zijn, zijn beide op $-1.2 \mathrm{mEq} / \mathrm{min}$ gesteld. Duidelijk is te zien dat het ADH toeneemt en de urine-excretie sterk afneemt. De bloeddruk (PAS) daalt, in tegenstelling tot de simulatie in figuur 5.2 warin de osmolaliteit vam liet plasma en de urine gering toeneemt.

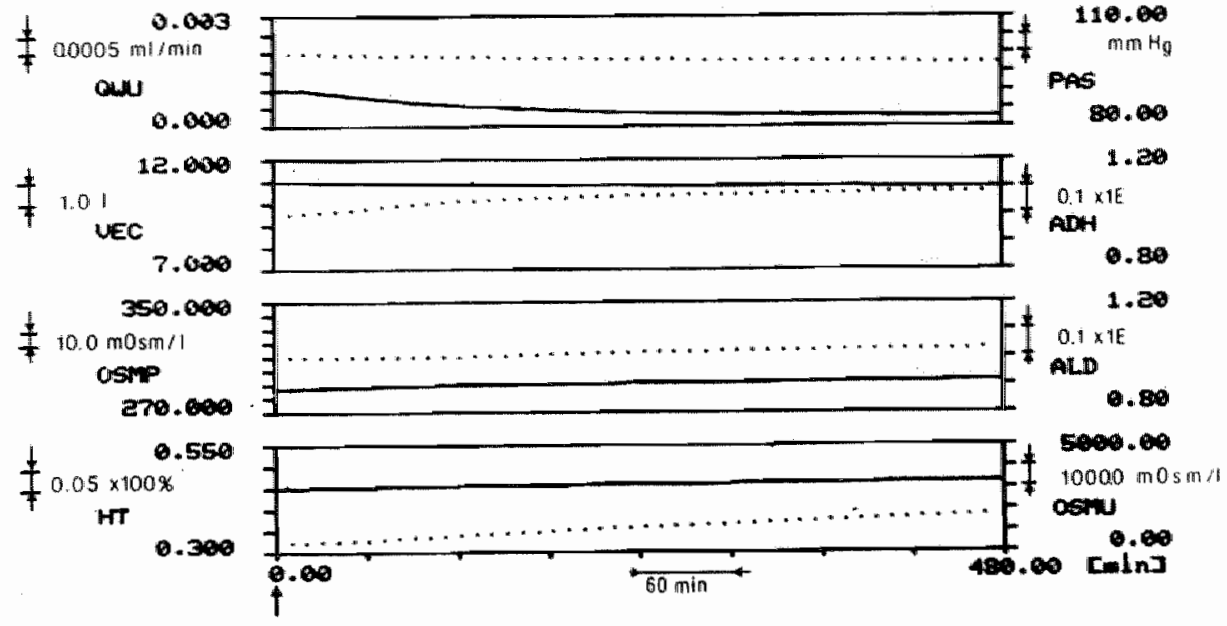

Figuur 5.3: Dorsten, zweten en zoutverlies (QIWL $=0.0081 / \mathrm{min}$, YNIN $=-1.2 \mathrm{mEq} / \mathrm{min}$ en YCLI $=-1.2 \mathrm{mEq} / \mathrm{min})$. De inname van water is $0(Q I N=0.0 \mathrm{l} / \mathrm{min})$. De graflekindeling is als bij figuur 5.2 .

\section{Water 1 inname}

Waterimname kan bij het model op 3 manieren worden geslmuleerd: drinken, hypotoon infuus of een fystologisch zout infuus. Er kan worden uftgegaan van een situatie warin sprake is van uitdroging zoals bij de vorlge experimenten. Tevens kan van een normalle situatie worden ultgegaan. Als er gewoon water drinken wordt gesimuleerd door de waterinname (QIN), die normal. $0.0015 \mathrm{l} / \mathrm{min}$ is, te verhogen tot $0.21 / \mathrm{min}$ gedurende 5 minuten dan kom dat overeen met het drinken van 11 iter water.

Figuur 5.4 laat zien dat na een korte periade de variabelen weer hun normale warden hebben gekregen. Het lichaam heeft t $1 j$ delijk een verhoogde diurese (QWU verhoogd). 


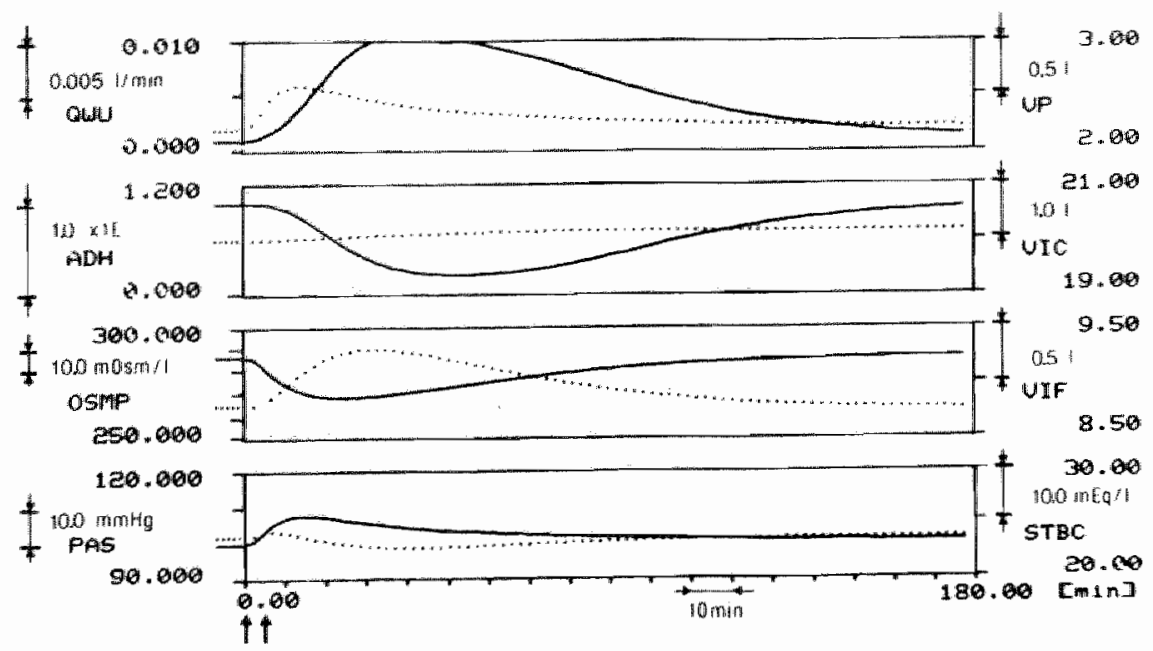

Figuor 5.4: 1 Liter water drinken. QIN $=0.21 / \mathrm{min}$ gedurende 5 minuten. Ale variabelen komen birnen 3 uur weer op hun nomale warden. Er is een verhoogde diurese gedurende deze uren. De grafieklndeling is overeenkomstig de opmerking bij Elguur 5.2.

Figun 5.5 laat de gevolgen zlen als er 1 liter water intraveneus wordt toegediend. Dit wordt gesimuleerd door QVIN, die normal 0 1/min is, te verhogen tot $0.2 \mathrm{ml} / \mathrm{min}$ gedurende 5 minuten. Dat komt overeen met een infus van 1 liter zuiver water. Ook hier geldt dat door een ver-

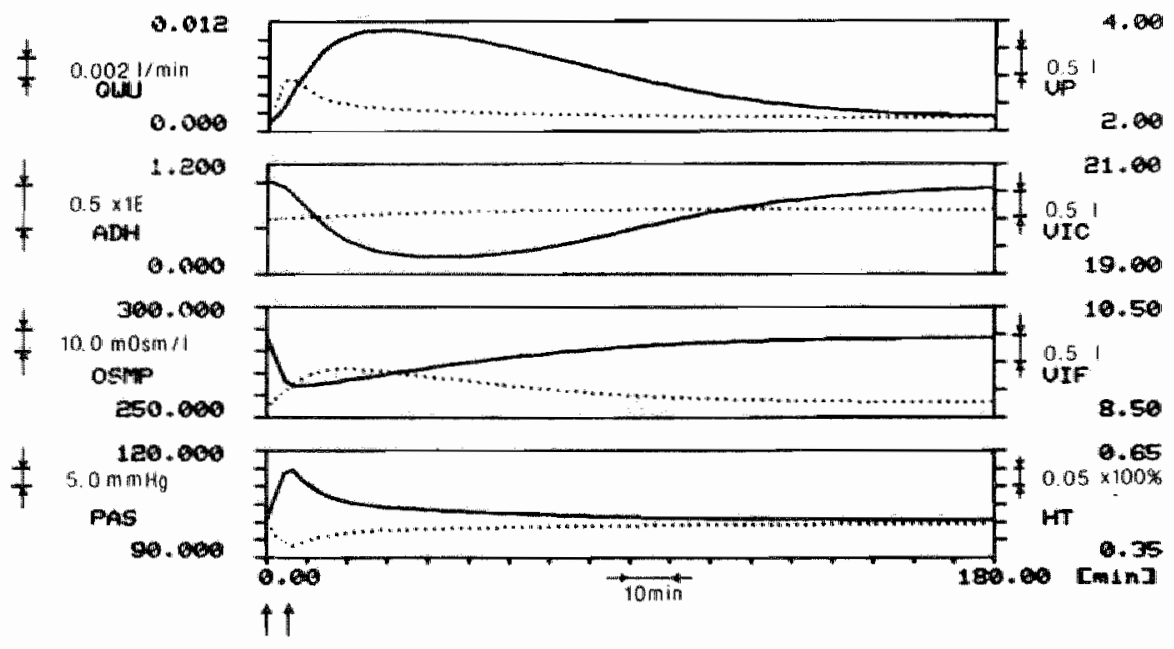

Figuur 5.5: 1 Liter waterinfus QVIN $=0.2 \mathrm{~m} 1 / \mathrm{min}$ gedurende 5 minuten. $\mathrm{Na} 180$ minuten ( 3 ur) $2 \mathrm{ijn}$ alle 8 variabelen weer als op tijdstip 0 . De indeling is overeenkomstig de opmerking bij figuur 5.2 . 
hoogde diurese de variabelen ma korte tijd weer hun nomale uitgangswaarden bereiken.

Figuur 5.6 laat de gevolgen zien van het intraveneus toedienen van 1 Liter fysiologisch zout over 5 ininuten, warbij de natrium inname (XNIN) en de chloor inname beiden $31 \mathrm{mEq} / \mathrm{min} \mathrm{zijn}$. Dit komt overeen met een hoeveelheid natrium en chloor van $154 \mathrm{mEq}$. In Iiguur 5.6 is te zien dat het model reageert met een bloeddrukstijging (PAS). Ook hier gaat de nier regulerend optreden: door de stifging wan de bloeddruk zal de nier zout gaan uitscheiden. Dit duurt verscheidene uren. Als het zout wordt uitgescheiden, volge daarmee ook de wateruitscheiding.

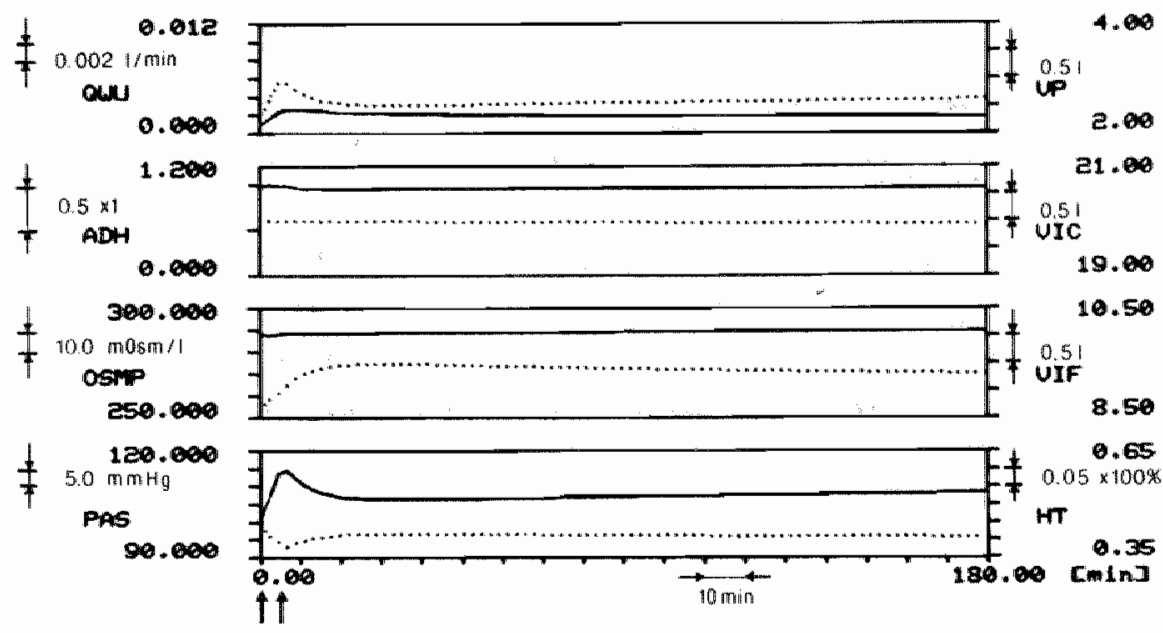

Figuur 5.6: Infuus met fysiologisch zout gedurende 5 minuten. QVIN $=0.2 \mathrm{l} / \mathrm{min}, \mathrm{YNIN}=3 \mathrm{~J}$ en YCLT $31 \mathrm{mEq} / \mathrm{min}$ gedurende 5 ininuten. De indeling is overeenkomstig de opmetking bij figuur 5.2 .

\section{G1ucosetolerantietest}

De glucosetolerantietest (GTT) kan aantonen of ienand een nomale glucose-insuline huishouding heeft. Deze glucosetolerantietest kan worden gesimuleerd. Over een periode van 50 minuten wordt via een infutus $50 \mathrm{~g}$ glucose gegeven. In figur 5.7 is te zlen dat de concentrabie van het glucose (ir het ECV) toeneemt en onmiddelifik na het stoppen van het infuus weer afneemt. Daarbif is te zien dat het glucose via de nier (YGLU) geklaard wordt. De glucosespiegel. is vrij snell weer op de normale uitgangswarde terug. Verder valt op de daling in de 


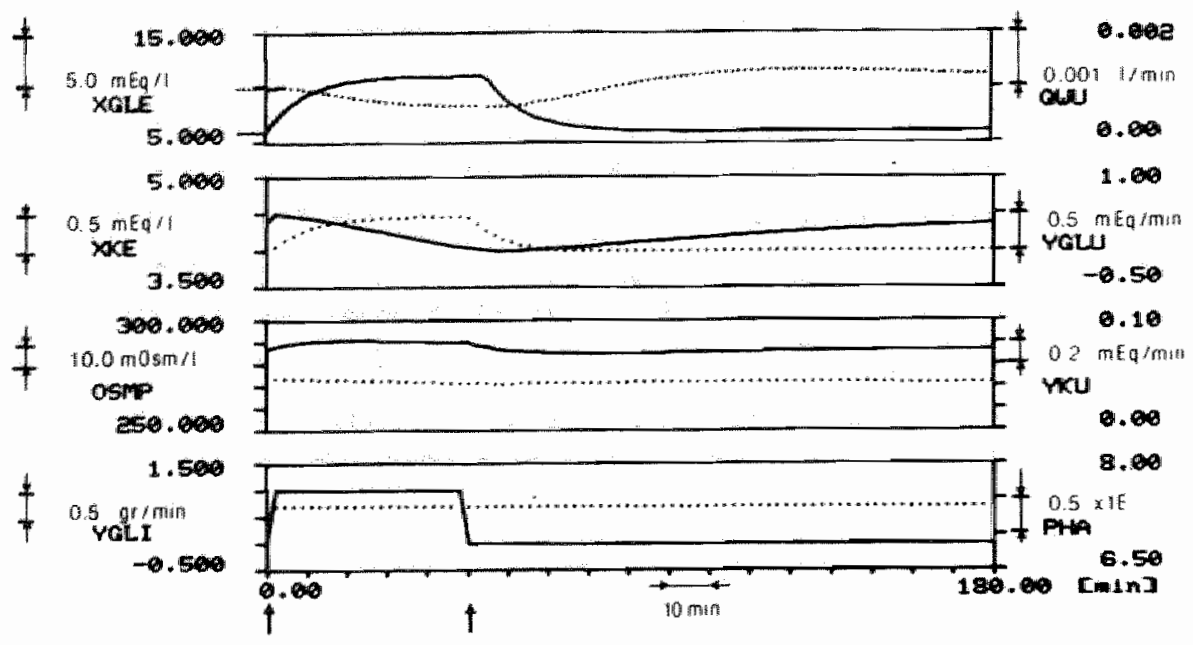

Figuur 5.7: Clucosetolerantietest (GTT). YGLI = $1 \mathrm{~g} / \mathrm{min}$ gedurende 50 ininuten. De indeling is overeenkomstig opmerking bij f. iguter 5.2 .

extracellulaire kaliumconcentratle. Bij een dlabetespatient zou de glucoseconcentratie (In het ECV) lang hoog blijwen na het stoppen wan de glucose-Infuns. Bij een lichte vorm van diabetes mellitus zal het insuline de glucosespiegel nog wel kunnen verminderen, mar het zal langzaan gaan.

Verhoogde $\mathrm{CO}_{2}$ inname

Als de fractie $\mathrm{CO}_{2}$ in de inademingslucht wordt verhoogd van $0 \%$ tot $5 \%$ gedurende 50 minuten neent de alveolalte ventilatie van $51 / \mathrm{min}$ toe cot $18 \mathrm{l} / \mathrm{min}$. In figur 5.8 is te zien dat de $\mathrm{CO}_{2}$ druk (PCAO) in het bloed gtjgt en de $O_{2}$ druk (PO2A) ook. Herbij is duidelijk te zlen dot de $\mathrm{CO}_{2}$ druk door een snel regelmechanjsme zo laag mogelijk wordt gehouden.

2unt-bage evenwicht verstoringen

Bi. zutrubase evenwfith verstoringen speelt de nfer een belangrifke rol blif het compensiat te mechanisme in het 1 ichan. Het 'long-term' gedrag van dit model bij respiratolte acidose en alkalose wordt door lkeda et al. uitgezet in het ph $-\left[\mathrm{HCO}_{3}\right]$ - vlak zoals in figuur 5.9 is gedaan. Curve OA correspondeert met de respons op een experiment warbij de inademingslucht lange tijd $10 \% \mathrm{CO}_{2}$ bevat. Curve $\mathrm{OB}$ correspon- 


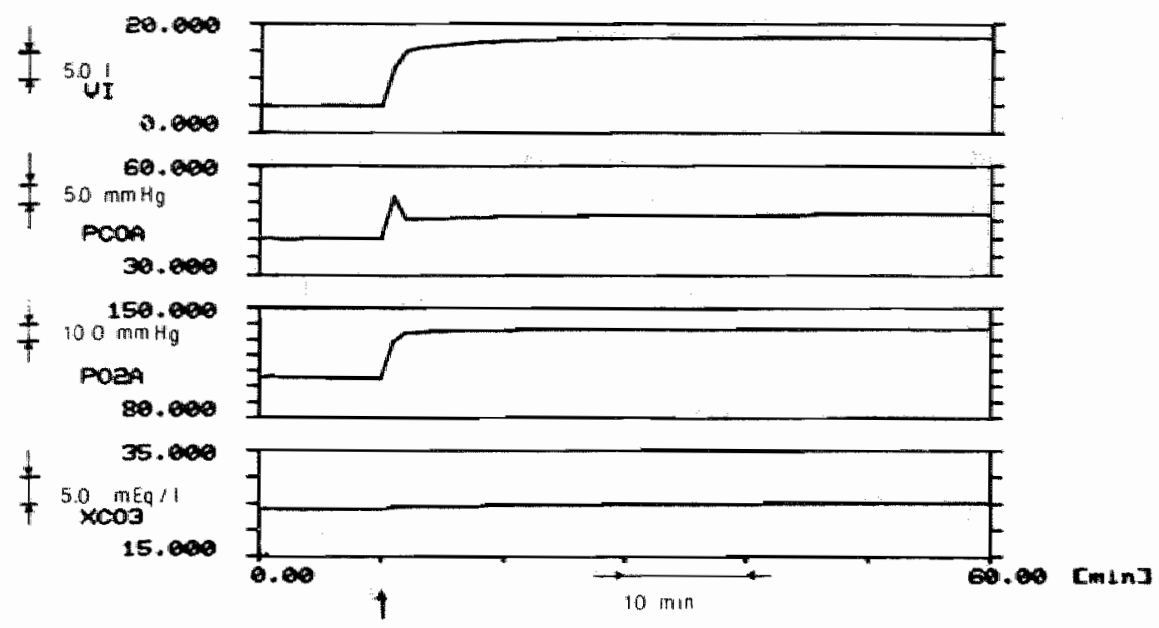

Figuur 5.8: De ademhaling bij verhoogd percentage kooldioxyde in de inademingslucht. Inademingslucht bevat $5 \% \mathrm{CO}_{2}$, d.w.z. FCOI $=0.05$. Zie de opmerking bij figuur $5.2 .^{2}$

deert met de respons bij hyperventilatie waarbij de ventilatie (VI) lange tijd 3 mall hoger is dan normal. In de eerste 2 uren van de experimenten $A$ en $B$ is er compensatie door intracellulaire buffering, daarna is er voornamelifk renale compensatie (aie figur 5.9). Ikeda et al. geeft aan dat de resultaten van dit model overeen komen met resultaten die andere auteurs gevonden hebben.

\section{Discussie}

Het computersimulatteprogramma FLuids is in het studlejaar $1981 / 1982$ voor het eerst gebruikt in het blok "de volwassene" (2.5). Een voorwarde voor aambieding var een complex model als flutus in het onderwijs is het kunnen beschikken over goede casulstiek. Een van de leerdoelen in dit blok is bestudering van de water-en zouthulshouding en de casus die door medewerkers en studentassistenten is ontwikkeld, i.s get̃spireerd op een casus uit dit blok. Het gat hierbij om een gevalsbeschrijwing van verdwalde wadlopers. Aspecten uit deze casus zoals dorsten, zweten, (zee)water drinken en datana deze uitgedroogde persoon een fysiologisch zout infuts geven, komen allemal aan de orde. Ruim twintig studenten hebben deze experimenten naar alle tevredentid gedaan en gaven in de discussies blijk de problematiek in de onderwis- 


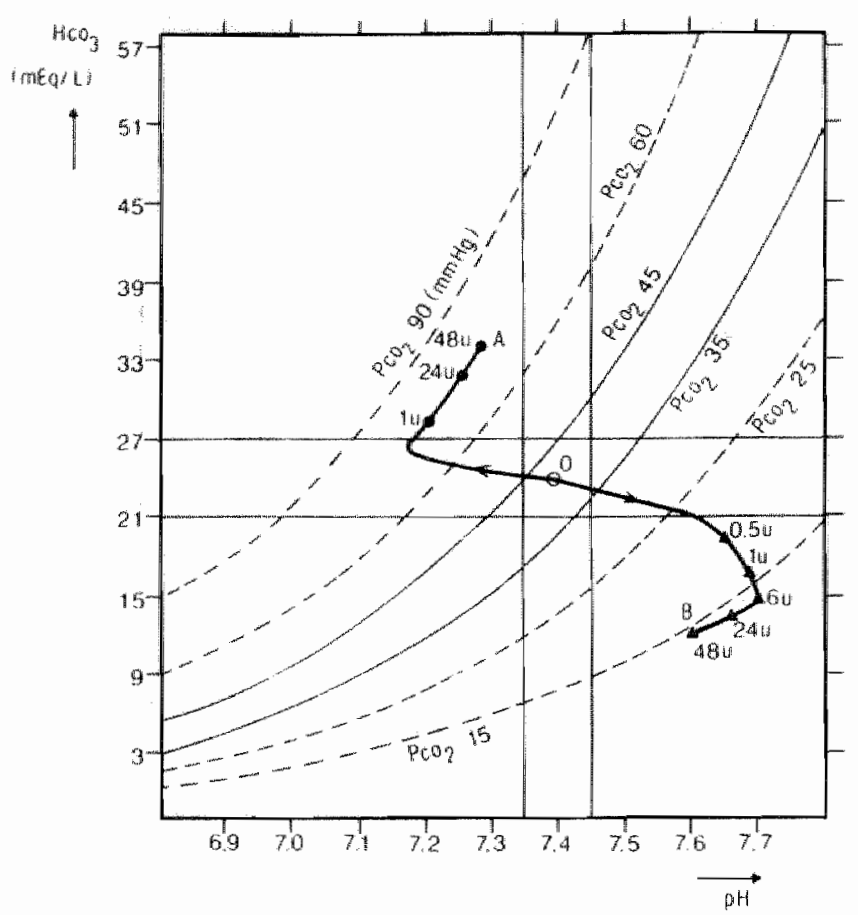

Figuur 5.9: Twee ziektebeelden met bijbehorende warden voor de arterieile bloed $\mathrm{pH}, \mathrm{HCO}_{3}^{-}$-concentratie en $\mathrm{CO}_{2}$ druk.

A. Hyperventilatie als $\forall \mathrm{r}=15 \mathrm{E}$ (na 48 uur) (gedeeltelijk gecompenseerde respiratoire acidose).

B. Inhalatie $10 \% \mathrm{CO}_{2}$ gedurende 48 uur (gedeeltelijk gecompenseerde respiratoire alkalose). (Ikeda et al, 1979).

groep aan te zullen pakken en de problemen nader te bestuderen in de 1. theratur. Sommige technische handelingen vereisen bij dit programa veel natugazetheid. Well loht verdient het anbeveling om een intervenrie in het model nitet te laten bestaan wit het gelijktijdig aanbrengen Wan $3-4$ verschillende veranderingen in het model, mar door dit in één handeling te doen. Ben voorbeeld: het toedienen van 1 liter fystologisch zout infuns verelst het nauwheurig veranderen van de water-, natriumen chloorinname. Het werken met het computersimulatieprograma Fluids en het complexe model van de water- en electroliethushouding verwist een goede voorberejding van de cesulstiek van de docent en is voor de studenten zonder een goede casus als laidraad niet goed magelijle. De resultaten met dit model zljn zeer illustratief voor de student en geven steeds goed aanleiding om verdere studie te maken van de water- en electrollethuishouding. Er dient een inhoudsdeskundige bereikbaar te zijn gedurende een sessle en niet lin het minst voor en nabespreking * 
Albisser, A.M., Y. Yamasaki, H. Broekhuyse, J. Tiran,

Hypercomplex models of insulin and glucose dynamics: do they predict experimental results? Ann. Biomed. Engin. 839 (1980).

Bergman, R.N.,

Integrated control of hepatic glucose metabolism. Fed.Proc. 36, $265(1977)$.

Bernards, J.A., L.N. Bouman,

Fysiologie van de mens. Bohn, Scheltema \& Holkema B.V., Utrecht (1979), 3e druk.

Celeste, R., E. Ackerman, l..C. Gatewood, C. Reynolds, G.D. Molnar, The role of glucagon in the regulation of blood glucose: moded. studies. Bull.Math.Biol. 40, 59 (1978).

Coballi, C., G. Federspil, G. Pacini, A. Salvan, C. Scandellari, An integrated mathematical model of the dynamics of blood glucose and its hormonal control. Mathematical Biosciences 58, 27 (1982).

Dickinson, C.J., P. Sherphard,

A digital computer model of the systemic circulation and kidney for studying renal and circulatory interactions involving electrolytes and body fluid compartments ("MACPEE"). J.Physio1. 216, 11P (1972).

Dickinson, C. .

A digital computer model to teach and study gas transport and exchange between lungs, blood and tissue (MACPUF). J.Physiol. $224,7 \mathrm{P}(1972)$

Dickinson, C.J.,

A computer model of human respiration. M.T.P. Press Limited, Lancaster, England (1977).

Dickinson, C.J., D. Ingram, K. Ahmed,

A review of educational applications of a series of four models of circulation, respiration, body fluids and electrolytes, and drug absorption and distribution. In: Lecture Notes in Medical

Informatics (Eds. B. Barber et al.). Springer Verlag, Berlin, $471-478$ (1979).

Foster, R.O., H.W. Jones,

Computer simulation of glucose regulatory system in men. Diabetes 19. $373(1970)$.

Guyton, A.C., T.G. Goleman, H.J. Granger,

Circulation: overall regulation. Ann.Rev.Physiol. 34, 13 (1972).

Guyton, A.C.,

Textbook of medical physiology, 5th Ed. Philadelphia, W.B. Saunders Company (1976).

Ikeda, N., Farumo, M. Shitataka, T. Sato,

A model of overall regulation of body fluids. Arn. Blomed. Fng. 7, 135 (1979).

Lafferty, H.H., A.E.B. Giddings, D. Mangnall,

A digital computer model for glucose insulin dymamics. Comput. Biol. Med. 8, $41(1978)$.

MACPEE,

Computersimulation of kidneys and body-fluids. Manual, McMaster

Universily, Hamilton, Canada (1978).

MACPUE,

Computer simulation of gas exchange and citrculation. Manual

McMaster University, Hanilton, Canada (1977).

Milhorn, H.T., jr.,

Simulation of the respiratory control system. Simulation 43,169

(1976). 
Reed, C.M., V.F. Sheppard,

Regulation of fiuld and electrolyte balance: A programed instruccion in clinlcal physlology. Saunders Company, Philadelphin (2e edition) (1977).

Sintith, K.,

Fludds and electrolytes, a conceptual approach. Churchill Livingstone Inc. New York (1980).

\section{Literatur $11 \mathrm{j} \mathrm{st}$}

Berger, A.J., R.A. Mitchel1, J.H. Seweringhaus,

Regulation of respitation (r). N. Eng.J.Med, 297, 92 (1977).

Bergman, R.N., M. El-Refai,

Dynamic control of hepatic glucose metabolism. Studies by experiment

and computer simulation. Ann. Biomed. Eng. 3, 41.1 (1975).

Blake, T'.R., J.F. Gross,

A mathematical model of fluid exchange from an array of capllaries. Microwasc.Res. 19, 80 (1980).

Blaine, E.H., J.O. Davis, P.D. Hartis,

A steady-state control analysis of the renin-angiontensin-aldosterone system. Circ.Res. 30, 713 (1972)

Bleich, H.L.,

Computer evaluation of acjd-base disorders. J.Clin. Invest. 48,1689 (1969).

Cameron, W.H. .

A model framework for computer simulation of overall renal function.

J.Theor. Biol. 66, $551(1977)$.

Foster, D., J.A. Jacquez, E. Danlels,

Solute concentration in the kidney. Il. Input-output studies on

a centrall core model. Mathematical Bioscience 32, 337 (1976).

Guyton, J.R., R.O. Foster, J.S. Soeldner, M.H. Tan, G.B. Kahn,

L. Koncz, R.E. Gleason,

A model of glucose insulin homestasis in man that incorporates

the heterogeneous fast pool theory of pancreatic insulin release. Diabetes 27,1027 (1978).

Guyton, A.C., T.G. Coleman, D.B. Young, T.E. Lohmeier, J.W. DeClue, Salt balance and long term blood pressure control. Ann. Rev.Med. 11. $15(1980)$.

Hagander, P., K. -G. Tranberg, J. Thorel1, J. Distefano, Models for the Insulin response to intravenous glucose. Mathematicall Bioseience 42,15 (1978).

Itacquez, J.A., D. Foster, E. Danlels,

Solute concentration in the kldney. I. A model of the renal medulla and its limit cases. Mathematical Bioscience 32, 307 (1976).

Jaros, G.G., A.C. Guyton, J.G. Colleman,

The role of bone in short-rerm calcium homeostasis: an analog-

digital computer simulation. Ann. Biomed. Eng. 8, 103 (1980). Marsh, D. H. ,

Simulation of biological systems: the kidney. Simulation 50, 197 $(1977)$.

Stetr, E. B.,

Application of control theory to endocrine regulation and control.

Ann. Blomed. Eng. 3, 439 (1975).

Stephenson, J.L.,

Analyg Ts of the translent behaviour of kidney models. Bull. Math.

Biol. $40,211(1978)$. 
Tiran, I., K.R. Galle, D. Porte jr.,

A simulation model of extracellular glucose distribution in the human body. Ann. Biomed. Eng. 3, 34 (1975).

Toates, F.M., K. Oatley,

Control of water-excretion by antidiuretic hormone: some aspects of modeling the system. Med.B101. Eng.Comput. 15, 579 (1977).

Wells, C.H., W.M. Thompson, C.S. Holm,

Instruction in renal physiology on a ainicomputer-based educational system. Physiologist 16,678(1973). 
HOOFDSTUK 6

Computersimulatieprogramna FARMA

Onderwijsdoe1

Het computersimulatieprogramma FARMA makt het de studenten mogel jk met de basisbegrippen uit de farmacokinetiek te experimenteren, am de hand van een open twee-compartimenten model. Voor de medische student is de kinetiek van de opname, distributie en elininatie van een geneesmiddel in het lichaam een onderwerp waamee hij in diverse fases van thet curriculum wordt geconfronteerd. Een methode van expermenteren kan dan voordelen bieden boven het uitsluitend werken met wiskundige formules. Met een progranma als FARMA kan de student vertrouwd raken met begrippen als halfwardetijd, klaring, snelheidsconstanten, het begrip "oppervlak onder de kurve" en verdelingsvolume van een geneesmiddel. Er kan een serie experimenten worden uitgevoerd zoals het laten afnemen van de eliminatie van een stof of het varierren van de quotient van de snelheidsconstanten tussen twee compartimenten (Greenblatt en Koch-Weser, 1975; Lammers et al.,1980; Niazi,1977; Bischoff, 1980; Niazi,1979; A.G. Goodman et a1.,1980).

Met dit op zich eenvoudige en nog steeds veel gebruikte madel is en aantal zaken wit de farmacokinetiek inzichtelijk te presenteren. Voor een meer op de praktijk van de geneesniddelen en de receptuur gerich programma wordt de student verwezen natr het computersimulatieprograma MACDOPE (Bloch et al., 1980).

\section{Het open twee compartinenten mode 1}

Het open twee compartimenten model met een centrall compartiment (1) en een perifeer compartiment (II) 1 is schematisch weergegeven in figuur 6.1 .

De eenvoudigste toedieningswijze van een geneesmlddel is de dosis (D) direct in het centrale compartiment te brengen, dus wia een intraveneuze toedieningswijze. De plasmaconcentratie in het centralcu compartiment die onmiddellijk na toediening wordt bereikt is dan:

$$
C_{1}(0)=D / v_{1}
$$


warbij op dat moment de concentratie in het perifere compartiment $\mathrm{C}_{2}(0)$ nithil 1s. Uitgande van een open twee compartimenten node kim men een verklaring geven van het bifasisch verloop wan de concentatic In het plasma (compartiment 1 ), dat als volgt verloopt:

$$
C_{1}(t)=A \exp (-\alpha t)+B \exp (-B t) ; C_{1}(0)=A+B
$$

warbif en $B$ tijdscontanten zijn en $A+B$ de geneesmiddelenconcentrat le op $t=0$ is. Het snel dalende eerste deel van de curve noemt men de a fase of distrtbutiefase, het tweede minder snel dalende deel de $\beta$-rase of eliminatiefase. Het volume wan het centralle compartiment $\left(V_{1}\right)$ is dan bepaald door:

$$
w_{1}=D /(A+B)
$$

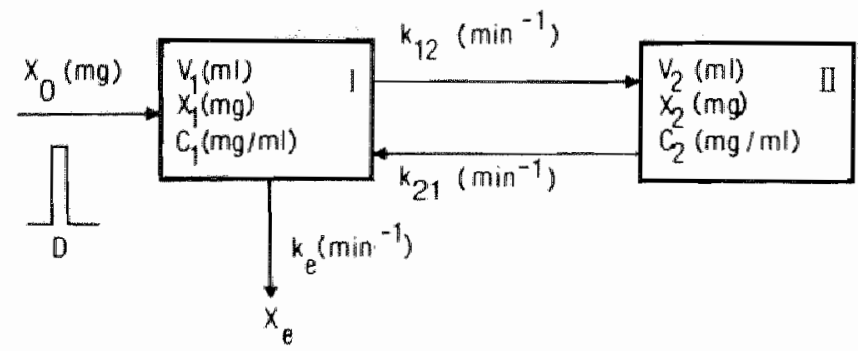

Figuur 6.1 : Het open twee compartimenten model met de sneltheidsconstanten $k_{12}$, $k_{21}$ en ce eliminatieconstante $k_{e}$. $\left(X_{0}\right.$ is de hoeveelheld stof die het licham binnenkomt; $x_{e}$ de (cummulatleve) hoeveelheid die het licham verlaat; $x_{1}$ en $X_{2}$ de hoeveelheden in compartiment $I$, resp. II; $\mathrm{C}_{\Perp}$ en $\mathrm{C}_{2}$ de concentratles in compartiment I, resip. II.)

Als wordt uttgegaan van een reeël bestaande plasmaconcentratiecurve din zijn door parameterschatting de 4 constanten voor deze formule te bepalen: a en door sehatting via de halfwardetijden (of door conscructo ide methoden) en A en B door constructie methoden zoals in 1 iguur 6.2 Lis te alien.

Per definitie is de onderlinge relatie tussen de hybride constanten. $a_{*}, A$ er $B$ en de snelheidsconstanten $\mathbb{K}_{12}, k_{21}$ en $k_{e}$ " warmee het twee compartimentenmodel wordt gedefinieerd, als volgt:

$$
\begin{aligned}
& k_{E}=\frac{A+B}{\frac{A}{C}+\frac{B}{B}} \quad\left(\mathrm{~min}^{-1}\right) \\
& k_{21}=\frac{\alpha B}{k_{e}}=\frac{A B+B \alpha}{A+B} \\
& k_{12}=\frac{A B}{(A+B)^{2}} \cdot \frac{(B-\alpha)^{2}}{k_{21}} \quad\left(\min ^{-1}\right)
\end{aligned}
$$


De klaring wordt daarbif gedefinieerd door $k_{e} v_{1}$ (Greenblatt en KochWeser, 1975).

Het volume van het perifere compartiment $\left(v_{2}\right)$ kan worden bepald uit het volume van het centrale compartiment $\left(V_{1}\right)$ ende smeltheidsconstanten.

$$
v_{2}=\frac{k_{12}}{k_{21}} v_{1}
$$

Als uitgegaan wordt van de massabalans en gesteld wordt dat de hoeveelheid van de stof die op een bepaald tijdstip uit het 1ichaam verdwenen $\mathbb{1 s}\left(\mathrm{X}_{\mathrm{e}}\right)$ gelljk is an de hoeveelheid die in het licham is ingebracht minus dat wat zich in de beide compartimenten bevindt, dat kan de Loo-Riegelman en Wagner-Nelson vergelljking

of $\quad \begin{aligned} & D=c_{1} v_{1}+c_{2} v_{2}+x_{e} \\ & C_{1} v_{1}+c_{2} v_{2}+v_{1} k_{e} \\ & t=0\end{aligned} C^{t=T} c_{1}(t) d t \quad$ (mg)

opgesteld worden warbij woor de hoeveelheid van de stof die op een bepaald tijdstip ( $T$ ) wit het lichaam verdwenen is $\left(x_{e}\right)$, geldt:

$$
x_{e}=v_{1} k_{e} \int_{t=0}^{t=T} c_{1}(t) d t
$$

Als T naar oneindig gat dan wordt het belangrijke farmacokinetische begrip "oppervlak onder de curve" (area under the curve of AUC) als volgt gedefinieerd

$$
A U C=\int_{t=0}^{t=\infty} \quad C_{1}(t) d t
$$

2ie hierbij ook figuur 6.3 (Currey, 1974; Notari,1975).

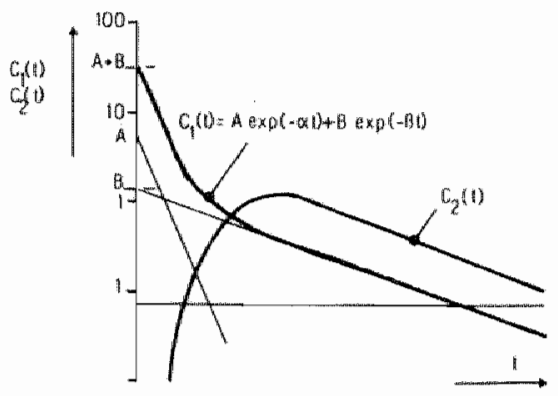

Figuur 6.2 : De biexponentiële representatie van de plasmaconcentratie van een stof in het centrale compartiment en de concentratie van de stof in het perifere compartiment. 


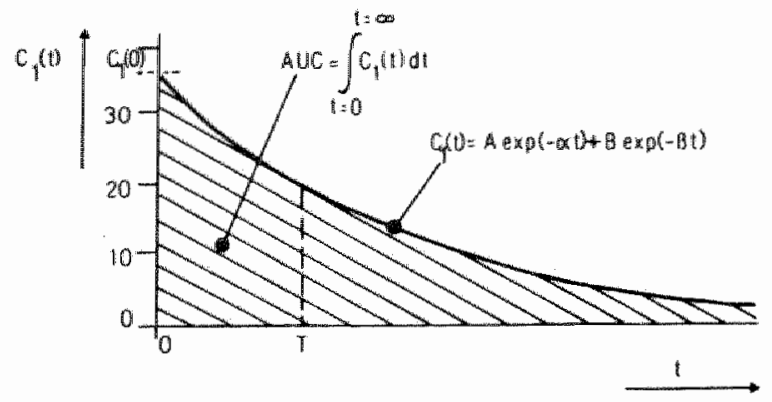

Figur 6.3 : Het verloop wan de geneesmiddelenconcentratie $C_{1}$ als functie van de tijd en het begrip "oppervlak onder de curve" (Area under the curve; AUC).

Wu is het stelsel vergelljkingen woor de beide concentraties volledig bepald en zlet er als volgt uit:

$$
\begin{aligned}
& \left.\left.\frac{\mathrm{d} C_{1}}{\mathrm{~d} t}=-\left(\mathrm{k}_{12}+\mathrm{k}_{\mathrm{e}}\right) \mathrm{C}_{1}+\mathrm{k}_{21} \mathrm{C}_{2} \frac{\mathrm{v}_{2}}{\mathrm{v}_{1}} \quad \text { [mg/(m1.min }\right)\right] \\
& \frac{\mathrm{dC}_{2}}{\mathrm{dt}}=+\mathrm{k}_{12} \mathrm{C}_{1} \frac{\mathrm{v}_{1}}{\mathrm{v}_{2}}-\mathrm{k}_{21} \mathrm{C}_{2}
\end{aligned}
$$

De volledige opbouw en 1 isting van het model worden in appendix 6.1 gegeven.

Resultaten

Een experiment dat met het computersimulatieprogramina FARMA te simuleren is, is een voorbeeld; beschreven door Greenblatt voor het an*iolyticum chlordiazepoxide (Librium ${ }^{R}$ ) na toediening van een intraveneuze bolusinjectie van $25 \mathrm{mg}$ (D) van het farnacon aan een mannelifke vrijwliliger van $75 \mathrm{~kg}$ (Greenblatt en Koch-Weser, 1975). Het experiment 1 s anders opgezet dan bij andere computersimulatieprogramnas" 5 .

Bij deze ene casus wordt witgegan van de volgende gegevens:

$$
\begin{aligned}
& t^{\frac{1}{2} \alpha}=0.2 \text { unr } \\
& t^{1} B=12 \text { unt } \\
& \text { B }=1.02 \mu \mathrm{g} / \mathrm{mL} \\
& C_{1}(O)=4.2 \mu / g / m L \quad(=A+B)
\end{aligned}
$$

Het programina berekent dan het volume van het centrale compartiment $\left(v_{1}\right)$, de tijdsconstanten ( $\alpha$ en $\beta$ ), de klaring, het verdelingsvolume, het volume van het perifere compartiment $\left(v_{2}\right)$. De parameters van het 


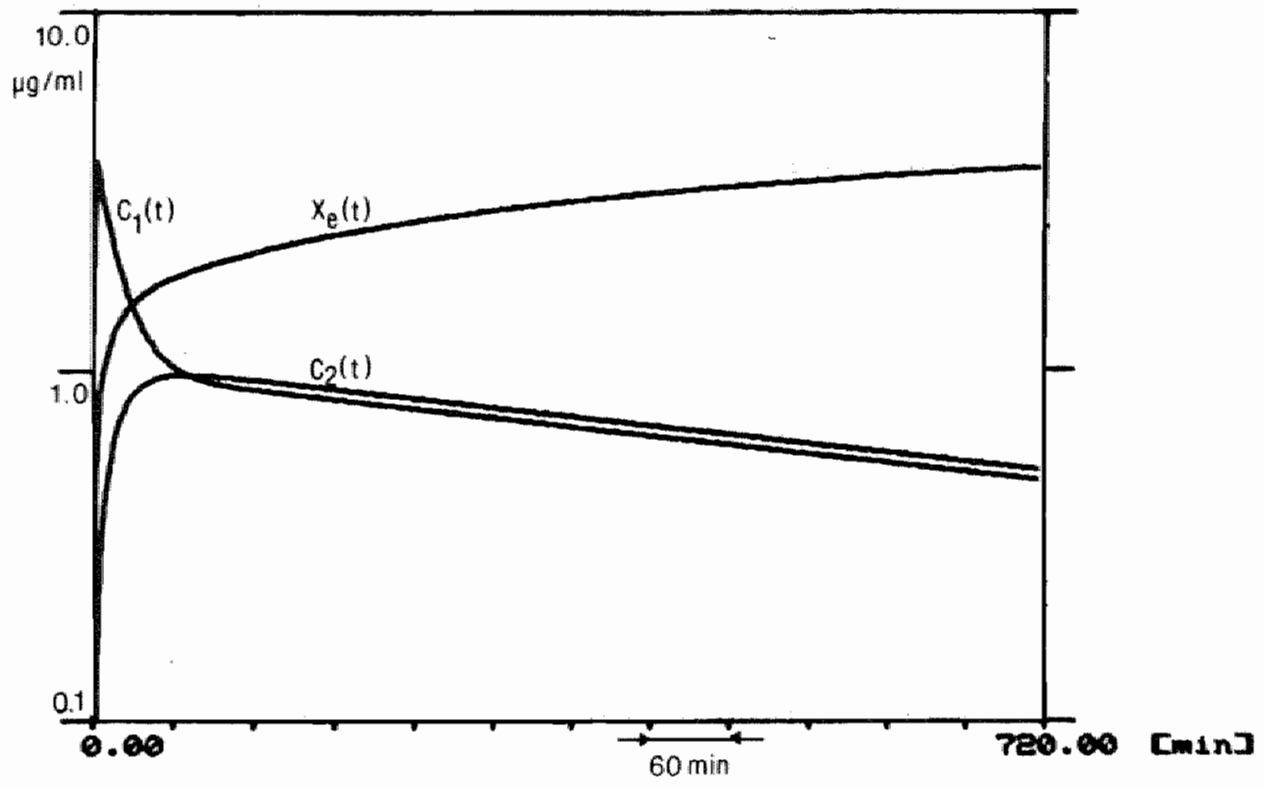

Figuur 6.4 : Het concentratiever loop van $c_{1}(t)$ en $c_{2}(t)$ en $x_{e}(t)$ (de cumulatieve hoeveelheid die het 1 ichaam verlaat) met $D=$ $25 \mathrm{mg}$ en $t^{\frac{1}{2} B}=720$ min bij chlordiazepoxide.

$\left(t_{2} \alpha=12 \mathrm{~min}\right.$, AUC $=1114.8, v_{\mathrm{d}}=\mathrm{D} /(\mathrm{B} . \mathrm{AUC})=23.291$, $v_{1}=5.91$ en $\left.V_{2}=16.21\right)$

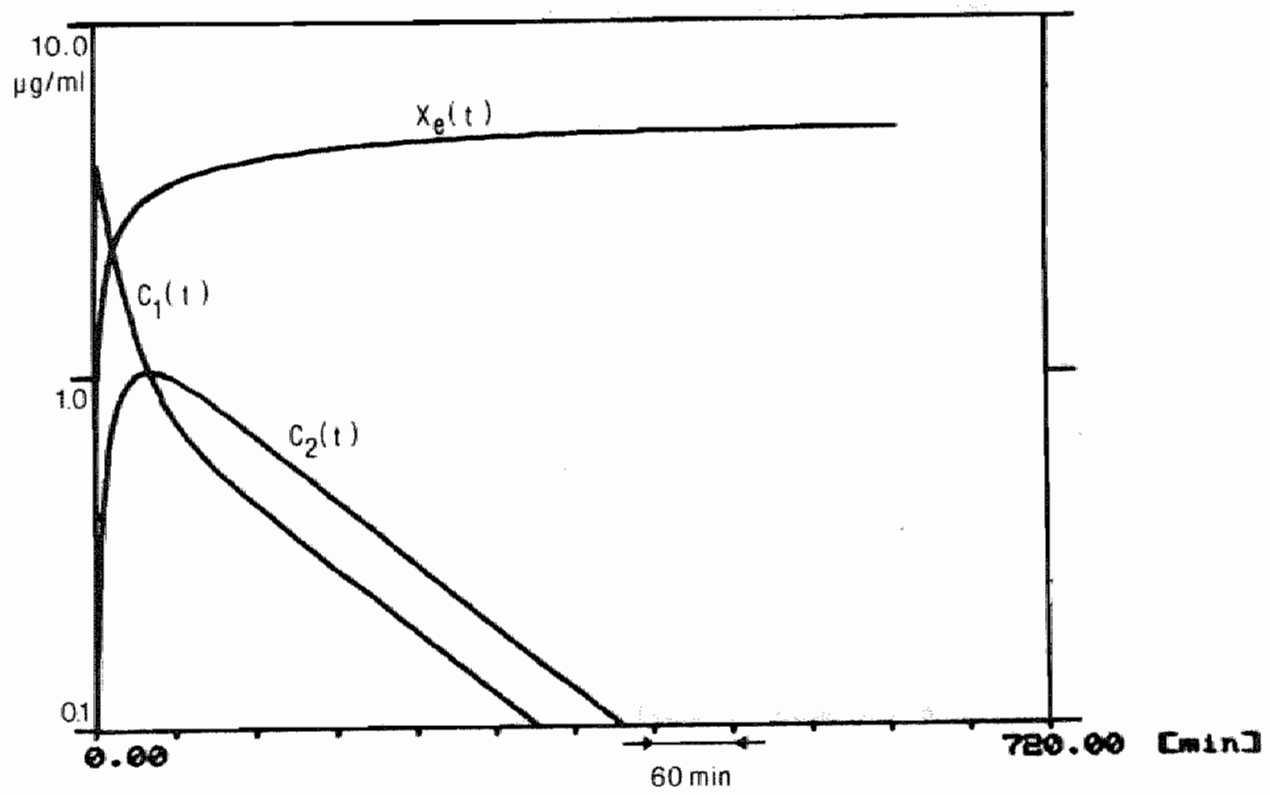

Flguur 6.5 : De concentraties $C_{1}(t), C_{2}(t)$ en $X_{e}(t)$ met $D=25 \mathrm{mg}$ en $t_{2} g=100$ min $(i . p \cdot v \cdot 720$ min).

$\left(\mathrm{t}, \alpha=12 \mathrm{~min}, \mathrm{AUC}=202, V_{\mathrm{d}}=\mathrm{D} /(\mathrm{B} . \mathrm{AUC})=47.81\right.$, $\left.V_{1}=5.9 \mathbb{1 e n} V_{2}=7.611\right)$ 
model 1 iggen hierme vast zodat de concentraties $C_{1}(t)$ en $C_{2}(t)$ met het twee compartimentemodel kunnen worden gesimuleerd met behulp wan de snelheldsconstanten. In $f\left(g t u r\right.$ t $6.4 \mathrm{sta} a n \mathrm{C}_{1}(t)$ en $C_{2}(t)$ weergegeven. Tegelljkertijd kan worden gesimuleerd en wergegeven hoeveel van deze stof het 1uchaam verlaten heeft $\left(X_{e}(t)\right)$.

In flgur 6.5 is een experiment weergegeven hoe het concentratieverloop is als de eliminatie om wat voor reden dan ook versneld is. Dit experiment is met een (aangepaste) versie van het model uitgevoerd, waarbij de snellheidsconstanten wel in eerste instantie onafhankelijke constanten $z i j n$.

\section{Discusiste}

Dit computersimulatieprogramma FARMA is pas gereed gekomen en is om die reden nog niet angeboden in een onderwijsblok. De casuistiek is nog enigszlns beperkt. Het is daarom nog niet uitgetest in het onderwijs zoals de andere programa's. Indien studenten dit programa willen wittesten of casuistiek antwikkelen of wijzigingen in het model willen arabrengen, is dit mogelijk. Voor een student die zlch wil verdiepen in modelmatige aampak van problemen zal het technische gedeelte geen belemmering hoeven te zijn.

\section{Referenties}

Bisschof, K. B.,

Current applications of physiological pharmacokinetics. J. Pharmacokinetics 39, 2457 (1980).

Bloch, R., D. Ingram. G.D. Sweeney, K. Ahmed, G.J. Dickinson, MACDOPE: a simulation of drug disposition in the human body.

Mathematical considerations. J.Theor. Biol, 87, 211 (1980).

Coleman, Tr. $\mathrm{C}$, H.C. Mesick,

Twenty (mostly plrysiological) problems that can be solved using a computer and basic programing language. Internal paper, Univ.

of Misisisppi, Mississippi (1978).

Currey, S.H.,

Drug disposition and pharmacokinetics. Blackwell Scientific

Publications, Oxford $(1974)$.

Greenblatt, D.J., J. Koch-Weser,

Drig therapy. Clinical pharmacokinetics. New Eng.J.Med. 293, $702(1975)$.

Gilman, A.G., L.S. Goodman, A. Gilman (eds),

The pharmacological basis of therapeutics. MacMillan publishing Co. Tnc., New York (1980).

L.ammers, W., F.A. Nelemans, Th.J. Boumman, J.van Nootdwijk, L. Offerhaus, W. M. Rosinga, A. Vermeulen (red.),

Algemene farmacotherapie. Stafleu's Wetenschappelijke Uitgeversmij. B.V. (1980), Ledden. 4e druk; deel I \& II. 
Niazi, S.,

Application of a programmable calculator in data fitting according

to one and two compartment open models in clinical pharmacokinetics. Comput. Programs Bioned. 7,41 (1977).

Niazi, S.,

Multicompartment pharmacokinetic analysis and simulations using a programable calculator. Int.J.Biomed.Comp. 10, 245 (1979).

Notari, R.E.,

Blopharmaceutics and pharmacokinetics. Marcel Dekker, New York, (1.975).

\section{Literaturijist}

Zie literatuurlijst van hoofdstuk 7 van het computersimulat leprogramal MACDOPE en verder:

Abramson, F.P.,

Two compartment pharmacokinetic models: computer simulations of

their characteristics and clinical consequences. J. Bharmac. Sci. 70 , 141 (1981).

Rossum, J.M. van; J. Burgers, G. van Lingen, J. de Ble,

Pharmacokinetics: A dynamic systems approach. Trends in Pharmacol.

Scliences (in press). 
HOOFDSTUK ?

\section{Computers inulatieprogramma MACDOPE}

\section{Onderwijsdoel}

Het computersimulatieprograma MACDOPl (versie MACDOPEX 1980) stelt de student in staat het kinetisch gedrag van een via een recept vootgeschreven geneesmiddel direct te zien bij een gezonde proefpersoon of patient.

Het programia is gebaseerd op een multi-compartiment model van het menselijk organisme. Het model beschrijft het transport van en naar ieder van die compartimenten. Er kunnen verscheidene geneesmiddelen tegelijkertijd en ap verschillende wijzen worden toegediend. Als output toont het programa hoe na toediening wan een geneesmiddeluitsluitend na het witschrijven van een compleet juist recept-da concentratie van de moederstof en eventuele afbraakproducten in de tijd werloopt in het bloed, de urine en enkele specifieke organen. De manier waarop dit programma oorspronkelijk door Bloch, Dickinson, Ingram a.a. is opgezet schept een simulatie van een reële klinische ongeving war farmacokinetisch onderzoek kan worden werricht. De dag begint bij alle simulaties 's ochtends om 8 uur, terwijl de proefpersonen over het algemeen "clean" $z$ ijn voordat een recept wordt gegeven.

Uit deze gegevens kan de student belangrijke farmacokinetische parameters en variabelen berekenen. Als jnput variabele kan een aantal eigenschappen wan het organisme afhankelijk van leeftijd of gesteldheid (b.w. een baby, een gezonde wolwassene of een 60-jarige net verminderde nierfunctie) worden ingesteld. Van een patient kan de student een tiental parameters veranderen zoals de mag, darm of urine pH, de makgledigingssnelheid, de glomerulaire fittratiesnelheid en de grootce van de afzonderlijke compartimenten, zoals het lichaansvetgehalte e.d. Nalast de patiënt-gebonden karakteristleken kunnen b.v. de biofarmaceutische eigenschappen van een geneesmiddel worden gewarieerd, zoals de absorptiesnelheid in het parenteral depot, de smelheid warmee een tablet uiteen valt etc. Daarnaast kan men een eigen geneesmidel ontwerpen door het geneesmlddel te defintëren met de genersmiddelparameters zoals de magabsorptiesnelheid, de intracellulaire en interstitie evenwichtssnelheden, "Wmax" van leverenzymen, dissociatie constante 
van leverenzymen. "Thas" van de secrete en reabsorptie in de nier, een diuresefactor, moleculgewichten pK. De student heet de beschikking over en 30-tal geneesmiddelen wit diverse hoofdgroepen zoals hartglycosides, anti-arythica, beta-blokkers, andibiotica, pijnstillers, sapmlddelen en psycho-stimulantia. Al met al is dit enen veelz $1 \mathrm{Jd}$ grograma wame veel relevante farmacokinetische experimenten door de student gedaan kunnen worden. Studenten kumen zich vagen stellen zoals: Wat voor lnvloed heeft en pH van de marg op een oral toegediend geneemiddel. Wat gebeurt er met de hallwardetijd als een paternt en gestoorde nierfunctle heeft? Hoe moet ik dan doseren? Hoe 1 s het verdelingsvolume? Als de zuurgrad van de urine hoger wordt, hoe verandert de halfwardet 1 jd? (Ingram et al., 1979; Bloch et al., 1980: Saunders a $1 ., 1982$ ).

\section{Het fystologische 8 compartimenten model.}

Het computersimulateprogramm MACDOPE is ontworpen door Blloch, Imgram en Dickinson aan de McMascer University te Hanilton, Canada, en in. Su. Bartholomew's Hospital te Londen, Engeland. Het is gebaseerd op een fysologische model dat opgebouwd is uit 8 conpartimenten: het plasira, de lever, de maag, de darm, een parenteral depot, de interstitiel rulate, de intraceliulafre rubte en een wetcompartinent (zie figuur 7. 1). In het plasma kan een geneesmiddel aan ejwit gebonden zijn of vilj, ongebonden, circuleren en beschikbar voor distributie. De opname van de geneesmiddelen vanuit het magdarmstelse1 verLopt wia actleve absorptie of passteve absorpte. Er vitud interactie plats cusgen geneemidnelen en macromoleculen op basts van bindingsaffinitelt, zoals binding an elwition, binding an tubulaire transportsystamen, binding atm metabolle leverenzymen. De distributie, de absorptie en de eliminat van een stof vindt wateenvoudige eerste orde processen plats. De elininate wan stofen windt plats via de excretie door de nier en/af forak door de lever. In de nier vindt de

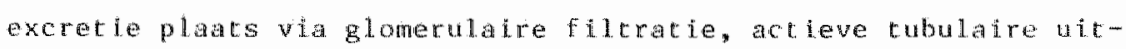
scheldtng en reabsorptio De afbrak wan leverenzymen verloopt win Michalis Monten kinetiek.

be concentrat les wan de stoffen in alle compartimenten worden besthroven door een acelsel van 8 diferential vergel ijkingen. In de appondices worden deze differential vergelijkingen en de afzonderlijke parameters beschreven. Tegelijkertijd wordt het verband tussen deze 
vergelijkingen en de FORTRAN notatiew jze gegeven en in analoge schema"s vastgellegd (Blach et al., 1980).

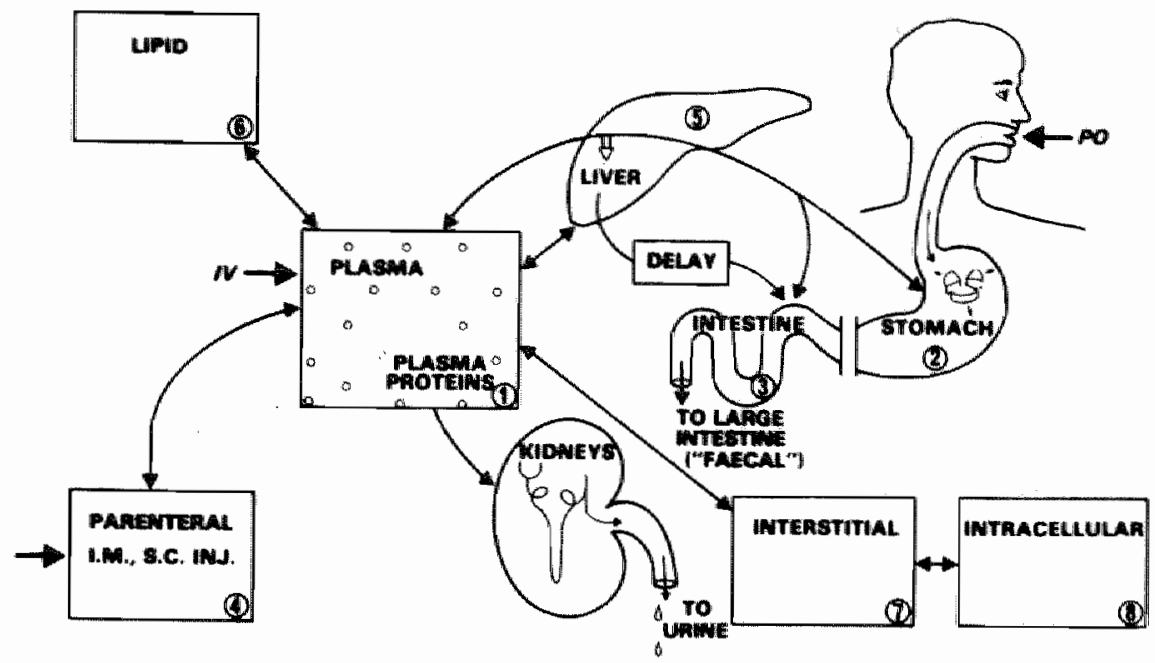

Figuur 7.1 : Het model MACDOPE met de 8 compartimenten. Het geneesmiddel kan oral. (PO), intraveneus (IV), subcutaan (SC) en intramusculair (IM) worden toegediend. (Saunders et all.,1982).

\section{Receptur}

Het schrijven van een compleet recept is een belangrijk leerdoel bij MACDOPE. In de handleiding en in het programa zelf staat hoe een compleet recept geschreven dient te worden en welke geneesmiddelen beschikbaar zijn.

In tabel 7.l wordt een overzicht gegeven van 40 stoffen waronder een tiental afbraakprodukten. In een enkel geval is er een handelsnaam vermeld or an te geven met welk geneesmiddel deze stof het beste overeen konts.

De volgorde van een recept en de mogelijkheden hierbij zijn:

a. Nam varn het geneesmiddel in thet Nederlands (zie tabel 7.1).

b. Hoeveel heid van het geneesmiddel (bij een grote dosering of bij een niet regulaire dosis werschijnt er een commentar regel op de therminal).

c. Eenheden behorende bij de hoeveelheden van het geneesmiddel ing, mg, $u g$ of $g / m i n t \cdot b \cdot v$. een infuus. 
Tabel 7.1 : Geneesmiddelennamen (in Nederlands) zoals die voorkomen in het computersimulatieprograma MACDOpE. De merknaam en de algemene nam wordt een aanal keer door elkaar gebrukt. Het uitschrijven van een recept dient echter met de naam zoalls hier vermeld is te geschieden. In het programa MACDOPE zijn van bijna alle geneesmiddelem afbraakprodukten opgenonen die echter niet in deze tabel $z i j n$ wermeld, zodat het totaal an stoffen bij MACDOPE ongeveer 40 bedraagt .

\begin{tabular}{|ll|} 
1. Natrium-salicylaat & 11. Inuline \\
2. Paracetamol & 12. Phenobarbital \\
3. Nortriptyline & 13. Lidocaine \\
4. Oxprenolol & 14. Digltoxine \\
5. Ampiciline & 15. Pentobarbital \\
6. Phenytoine & 16. Thiopental \\
7. Diazepam & 17. Anitriptyline \\
8. Aspirine & 13. Propranolol \\
9. Digoxine & 19. Anphetamine \\
10. Kanamycine & 20. Procainamide \\
& 21. Periciline \\
\hline
\end{tabular}

* In tegenstelling tot alle andere stoffen wordt hier een handelsnam gebruikt. De oorzaak is de afkomst van dit programma. In Noord Amerika is Aspirine geen handelsnaam.

d. Toedieningswijze: per os (PO), intramusculair (IM), intraveneus (IV), of continu infuus (IVDRIP).

e. Tijdsinterval (timing)

- onmiddellijke inname

statim

- om de. . uur

- 4 maa 1 daags

- 3 mal daags

- 2 maal dags

- na de maltijd

- voor de maaleijd

- per minuut of uur (bij infuus)
(STAT)

(Q...H)

(PER MINUTE/HOUR)

f. Limiet voor het antal doses voor een recept

- vour 3 dagen

(M3 of For 3 DAYs)

- voor 2 dagen, ena.

(M2) vaz

-3 doses

- 2 dosers, enz. 
In de voorbeelden die gegeven worden komen dan de volgende recepten voor (op MACDOPE format):

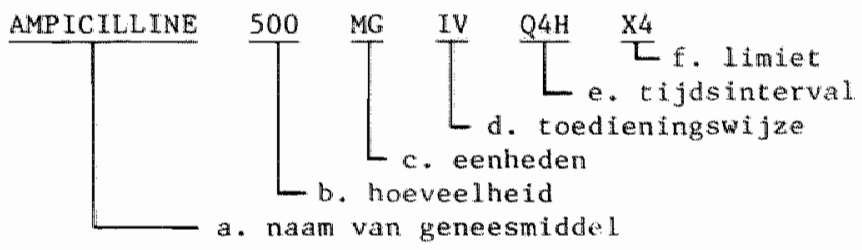

over het algemeen hebben de studenten hier geen moeilijkheden mee. lkt recept is echter pas compleet als de studenten hun naam hebben tugetypt (vgl. de handtekening op een echt recept), eerder wordt het rew cept niet geaccepteerd en kunnen de plasmaconcentraties niet berekend worden.

Zie voor een meer uthebreide beschrijuing van de nogelijkheden van dit computersimulatieprogramma de studentenhandleiding. 
Opbout yan het mode 1

Achterenvolgens komen alan de orde enzymreaktes, eiwltbinding in het plasma en het cotale 8 compartimentemodel en (war het werhelderend werkt) ook de FORTRAN notatiewijze van MACDOPE.

\section{Enzymreakties}

Enzymatische reakties bij het metabolisme van geneesmiddelen kunnen beschrewen worden m.b.v. Michaelis-Menten kinetiek. Mathemat isch is dit op te lossen via niet-lineaire differental vergelijkingen van het type $d u^{1}(t) / d t=G+Y . u^{i}(t)$ voor de substrat concentratie ${ }^{i}(t)$ van het substrat i (Bloch et al. 1980).

De parameters $G$ en $Y$ zijn echter funktes van alle substraten $(j=1 \mathrm{t} / \mathrm{m} n)$ die het 8 compartimentenodel van MACDope bevat (dus $G=G(t)$ en $Y=Y(t))$. Bloch, Ingram en Dickinson conen aan dat bij het gebrulk maken van de le orde Tayler benadering en een korte intervaltijd, deze vergelijking een gewone le orde differentialwergelijking is. De parameters $G$ en $Y$ mogen onder bepalde voorwarden constant gedacht worden zodat de differentialvergelijking numeriek kan worden opgelost. Welke grootheden hierbij een rol spelen laat de volgende formule zlen. Deze formule is de bovengenoemde niet-lineaire differential vergelijking $d^{1}(t) / d t=G+Y, u^{i}(t)$ op het willekeurige tijdstip $t_{0}$ met $u^{1}\left(t_{0}\right)=u_{0}^{i}$, en $G\left(t_{0}\right)=G_{0}^{i}$ en $Y^{i}\left(t_{0}\right)=\gamma_{0}^{i}$. Voor de reaktiesnellheid m.b.t. substrat 1 , indien er sprake is van meerdere substraten $(j=1 \mathrm{t} / \mathrm{m} \mathrm{n})$ woor dezelf de enzymiteakte.

$$
\frac{d u^{l}(t)}{d t}=\frac{v_{\max }^{\| 1}\left(u_{o}^{l} / k_{m}^{i}\right)^{2}}{\left(1+\sum_{j=1}^{n}\left(u_{o}^{j} / k_{m}^{j}\right)\right)^{2}}+\frac{v_{\max }^{1}\left(1+\sum_{j \neq i}^{n}\left(u_{o}^{j} / k_{m}^{j}\right)\right)}{\left(1+\sum_{j=1}^{n}\left(u_{o}^{j} / k_{m}^{j}\right)\right)^{2}} u^{i}(t)
$$

naarbij is $v_{\text {max }}^{1}$ de maximale reaktiesnelheid voor het substrat i en $k_{i n}^{i}$ de Michaelis Menten constante voor het substraat 1 . De termen met het somatieteken hebben betrekking op alle $n$ substraten warbij $j=1 \mathrm{t} / \mathrm{m} \mathrm{n}$ inclusief het substrat $i$. De reaktiesnelheid $m . b . t$, het 
substrat $i$ is dus niet alleen afhamkelijk van de substraatconcentrat ie $u^{i}(t)$ van het substraat $i$ mar van alle andere substraatconcentraties $u^{j}(t)(j=1 t / m n$, met uitzondering varn $j=i)$ op het willekeurige tijdstip $t_{0}$. In de analoge schema's komen $G$ en $Y$ overeen met $g_{01}$ en $y_{10}$ respectievelijk met $G(1)$ en $Y R$ in de FORTRAN nomenclatur. Opgenerkt dient te worden dat $G$ negatief is en een flux representeert die het plasma "verlaat".

\section{Eiwitbinding}

Een ongeveer gelijksoortig proces speelt zich af bij de thteraktie tussen de hoeveelheid ongebonden stof van een geneesmiddel i en plasmaeiwitten met een bepalde concentratie waraan een stof zich kan binden $[P]$ en $N$ bindingsplaatsen aar het eiwitmolecul (eiwitbinding). Hierbij wordt de affiniteit tussen de hoeveelheid van een stof $x^{i}$ en de bindingsplatatsen beschreven in termen van de dissociatie constante $K_{D}^{\ddot{h}}$ voor reversibele binding van die stof $i$. Stel het antal vrije bindingsplatsen aan het eiwit $R$ dan geldt de volgende relatie:

$$
N[P]=[R]+\sum_{i=1}^{n}\left[X_{R}^{i_{R}}\right]
$$

Bloch, Ingram en Dickinson geven dan aan dat voor de verhouding nieceiwitgebonden thoeveelheid van de stof $i$ tot de totale hoeveelheid van die stof $i\left(x^{i}\right)$ de verhouding $B^{i}$ geldt die als volgt kan worden beschreven:

$$
B^{i}=1-\frac{N[P] / k_{D}^{\mathfrak{l}}}{1+N[P] / K_{D}^{i}+\sum_{j=1}^{n}\left(u^{j} / K_{D}^{j}\right)}
$$

Daarbij heeft de term met het somatieteken betrekking op alle stoffen die op dat monent in het model aanwezig zijn (waarbij $\mathrm{j}=\mathrm{l} \mathrm{c} / \mathrm{m} \mathrm{m}$, inclusief de stof $i$ ).

De model beschri jving

Per compartiment en per genesmiddel kan met de massabalans een stelsul differentialvergelijkingen worden opgesteld wamee de vrije ongebonden concentraties var een stof in alle 8 compartimenten $\left(u_{1} t / m u_{g}\right)$ kunnen worden beschreven. Appendix 7.2 en 7.3 en het hier volgende llaw ten de samenhang biertussen zien. Voor het plasmacompartimert (1) geldt: 


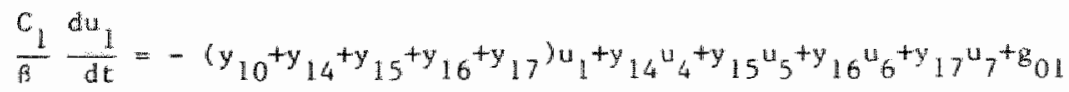

voor de mag $(2)$ :

$c_{2} \frac{d u_{2}}{d t}=-\left(y_{25}+y_{20}\right) u_{2}-g_{25}-B_{23}+y_{25} u_{5}+g_{02}$

voot de darm (3):

$\mathrm{c}_{3} \frac{\mathrm{du}}{\mathrm{dt}}=-\left(\mathrm{y}_{35}\right) \mathrm{u}_{3}-\mathrm{g}_{35}-\mathrm{g}_{30}+\mathrm{y}_{35} \mathrm{u}_{5}+\mathrm{g}_{23}$

voor het parenteraal depot $(4)$ :

$c_{4} \frac{d u_{4}}{d t}=-\left(y_{14}\right) u_{4}+y_{14} u_{1}+g_{04}$

voor de lever (5) met voor de ongebonden stof van $\mathrm{C}_{5} / \mathrm{B}$ :

$\frac{C_{5}}{B} \cdot \frac{d u_{5}}{d t}=-\left(y_{15}+y_{25}+y_{35}\right) u_{5}+y_{15} u_{1}+y_{25} u_{2}+g_{25}+y_{35} u_{3}+g_{05}$

Voor het vetcompartiment (6):

$c_{6} \frac{d u_{6}}{d t}=-\left(y_{16}\right)_{6}+y_{16} u_{1}$

voor het interstitieel compartiment (7):

$c_{7} \frac{d u_{7}}{d t}=-\left(y_{17}+y_{78}\right)^{u_{7}+u_{17} u_{1}+y_{78} u_{8}}$

Voor het Lntracellulair compartiment ( 8 ):

$\mathrm{C}_{8} \frac{d \mathrm{u}_{8}}{d t}=-\left(\mathrm{y}_{78}\right)_{8} \mathrm{u}_{78} \mathrm{y}_{7} \mathrm{u}_{7}$

Hierbij $z i j n C_{1}$ tot en met $C_{8}$ het volume van de compartinenten, $y_{i j}$ de flow tussen 2 compartimenten in $1 / \mathrm{h}$ en $\mathrm{g}_{\mathrm{ij}}$ de flux tussen 2 compartimenten in mg/h. Zie voor een verklaring van de symbolen de schema's ut appendices 7.2 en 7.3 . In het hier geselecteerde deel van de FORTRAN source listing van het model MACDOPE is te zien hoe de afgeleiden van de concentraties $Y(1) t / m Y(8)$ in de 8 compartimenten worden berekend, uit de termen die overeenkomen met de Elow's en de fluxen uit bovengenoemde vergelijkingen.

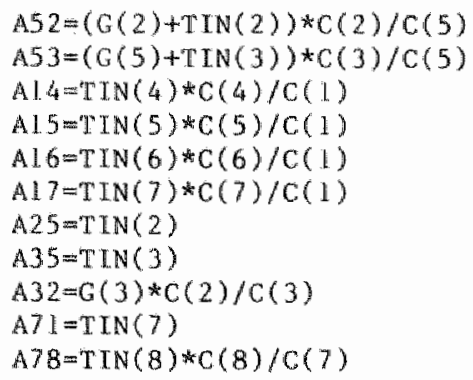




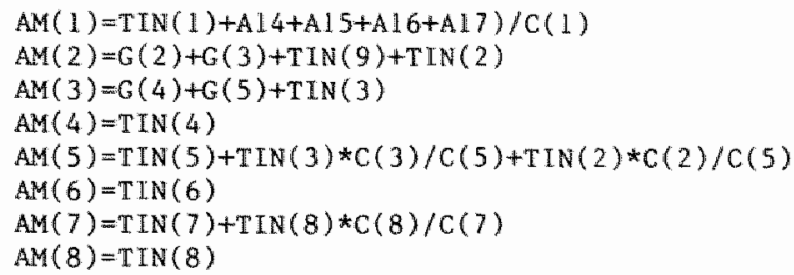

warbif $C(1) t / m C(B)$ een relatie hebben met de volumina $C_{1} t / m C_{8}$; $\operatorname{TIN}(1) t / m \operatorname{TIN}(8)$ een relatie hebben met de tijdconstanten $\mathrm{T}_{i j}$ en de flow $y_{i j}$, en $G(2) t / m G(6)$ een relatie hebben met de flux $g_{i j}$. Verder is TIN(1) een funktie van $y_{10} \mathrm{~m} . \mathrm{b} . \mathrm{t}$. de eliminatie en $\mathrm{G}(1)$ een funkte van $g_{01} \mathrm{~m} . \mathrm{b} . \mathrm{t}$. het ontstan van een plasmaconcentratie van een scot als er een afbraakprodukt is.

Uit de afgeleiden voor de concentraties van de stof (DERY(1) t/m DERY(8)) bepaalt het programma MACDOPE m.b. $v$. de numerieke twee staps Runge Kutta oplossingsmethode voor differential vergelijkingen de concentraties van de vrije, ongebonden geneesmiddelen en de afbrakprodukten $(Y(\mathbb{1}) \mathrm{t} / \mathrm{m} \mathrm{Y}(8))$.

In appendix 7.4 wordt de analoge notatiewijze gegeven van het model met de FORTRAN nomenclatuur (TIN,C,G, DERY etc.). In deze figur zijn tevens de relaties vermeld cussen dezo ForTRAN-namen en de patientparaneters Pl $t / m P 23$ met de geneesmiddelparmeters $101 / m 052$ (appendices 7.5 en 7.6). Er is hiermee een voor de praktijk bellangrijk direct verband gelegd Lussen de patiëntparameters en geneesniddelparameters in MACDOPE met de aktieve processen (Elux; $b_{i j}$ ten de passleve processen (Elow; $y_{i j}$ ) en met de modelbeschrijuing zoals BLoch, Ingram en Dickinson die gaven in 1980.

\section{Resultaten}

Met het computersimulatieprograma MACDOPE kunnen de concentraties in het plasma van alle stoffen die zich in het model bevinden, zowel de moederstoffen als afbraakprodukten tot maximaal 6 stuks op het beeld- 
scherm getekend en tegelijkertijd numeriek worden weergegeven. De y-assen warlangs de concentraties worden utgezet zijn zodanig ingedeeld dat het normale concentratever loop goed in beeld wordt gebracht.

In de fier beschreven casulst lek zall worden ingegaan op expormenton die studenten met MACDOPE kunmen doen.

Acety lsalicylguur (Aspirine ${ }^{\mathrm{R}}$ )

In figur 7.2 zijn resultaten te zien van twee experimenten die gedian zijn met acetylsalicylzutr (200 mg per os, om de 3 unr) bij een gezonde jonge mannelijke wrijwilliger. De plasmaconcentraties van acetylsalicylzur en de gevormde metaboliet salicylzuur zijn gesimuleerd aver 12 uur (van 8.00 tot 20.00 uur). Bij acetylsalicylzur treed geen accumulatie op. De halfwardetijd (ca. 20 minuten) is ook wan dien aard dat bij dit doseringsschema geen accumulatie optreedt. Bij het salicylzur is bij dit doseringsschema wel sprake van enige accumalatie. Als de ph van de urine alkalischer wordt (de urine pH,

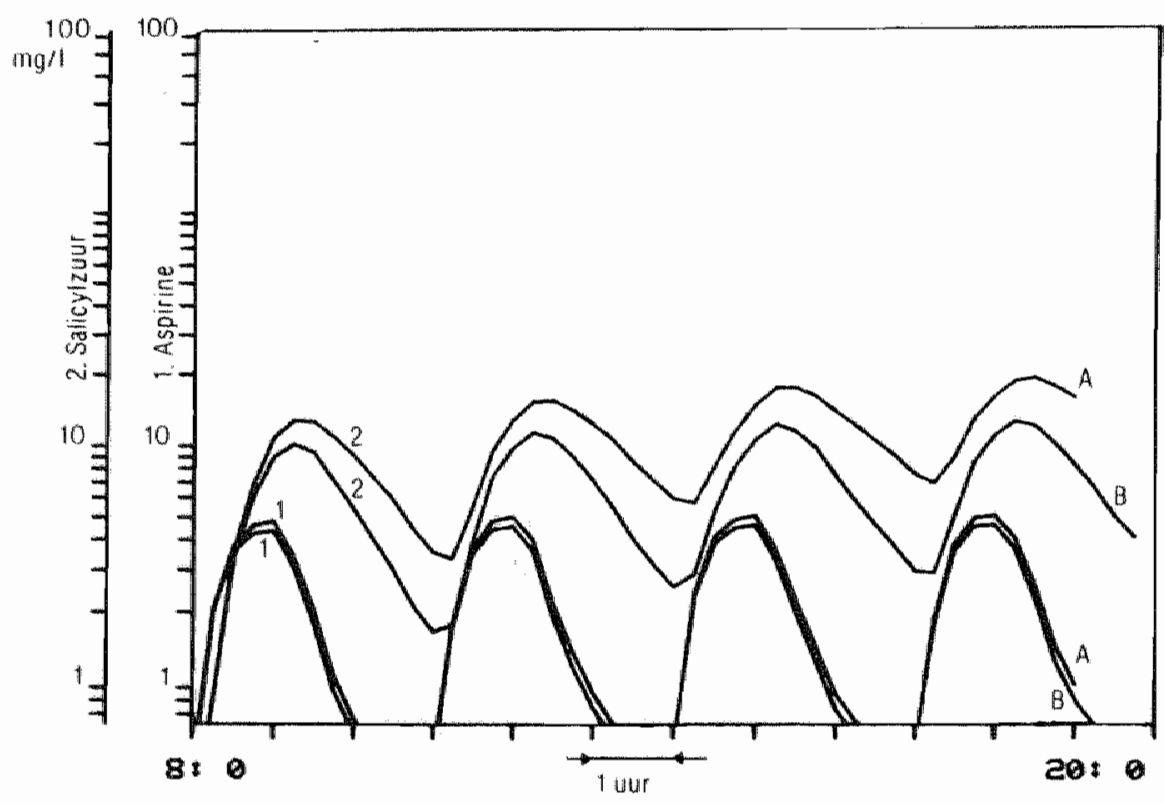

Figuar 7.2 : Het concentratieverloup van acetylsalicylaur (Aspirine ${ }^{\mathbb{R}}$ ) en sallicylatur bij toediening van 200 mig, per os am de 3 tur bij een gezonde jonge mannel i jke vrijwill iger (A) en bij dezelf cle vrijwilliger maar dan met een urine $\mathrm{pH}=$ 7.5 (alkalisch) (B). 
normalwate is 5.5 , wordt op 7.5 gebracht) dan verdwijnt het salicylzuur sneller uit het plasma. Er is dan minder reabsurptie in de not en dus minder accumulate van salicylzun in het licham.

studenten kumnen bij deze casus als zij dat willen ingan op de begrippen halfwardetijd, accumalate, afbrakstoffen, vetoplosbaratheid on pH verschillen bij plasma en urine in de nier. Deze casus is vaak een soort introductie voor de mogelijkheden die dit programa biedt.

\section{Ame íc il ine}

In figuur 7.3 zijn resultaten te zien van 4 aparte experimenten dic gedaan zijn met het antibioticum ampicilline bija. een jonge mannelijke vrijwilliger, b. een pasgeborene, c. een 80-jarige man en di. een 50- jarige vrouw met een gestoorde nierfunctie. Bij deze casus wordt de studenten gevraagd nar hun begrip over halfwardetijd, verdelingsvolume en klaring. Studenten dienen bij dosering rekening te bouden met het lichaamsgewicht. Bij de wolwassen vrijwilliger van $75 \mathrm{~kg}$ is $500 \mathrm{mg}$ ampicilline i..v. gegeven (curve a.). Bij de pasgeborene van $4.5 \mathrm{~kg}$ licharmsgewicht is $50 \mathrm{mg}$ ampicilline i.v. gegeven (curve b.). Bij een patient met een nierfunctiestoornls is het van groot belang te zien dat halfwardetijd sterk verlengt is en sterke accumulatie optreedt als een herhallingsdosis na eenzelfde tijd wordt gegeven als gebruikelijk bij een gezonde persoon. Daarom dient in het geval van een pat fënt met een nierfunctiestoornis in het algemeen voorzichtigheid in acht te worden genomen (curve d.). Studenten kunnen door constructie in de figuur en uitgaande wan farmacokinetische theor le hierover bepalen wat de halfwardetijden zijn en de concentraties op het moment evon na i.v. toediening ( $C_{0}$; wordt verkregen door extrapolatie van de curve in de eliminatiefase nar $t=0)$. Uit de formule voor de berekenting van het verdelingswolume $\left(W_{d}=D_{L}, v_{.} / C_{0}\right)$ en voor de berekening van de kJaring (klaring $=0.693 \mathrm{~V} / \mathrm{d} / \mathrm{w}_{2}$ ) kunnen studenten een duldelijk overzilcht leren krijgen over het probleemveld van de farmacokinetiek (Saunders et al.,1982).

Discussie

Het computersimulatieprogramna MACDOPE is enkele jaten incensief en net als AORTA vanaf het begin in gebruik. Het is vanaf het studiejatur 1978/1979 opgenomen in het keuzeblok farmacologie en in de blokken over 


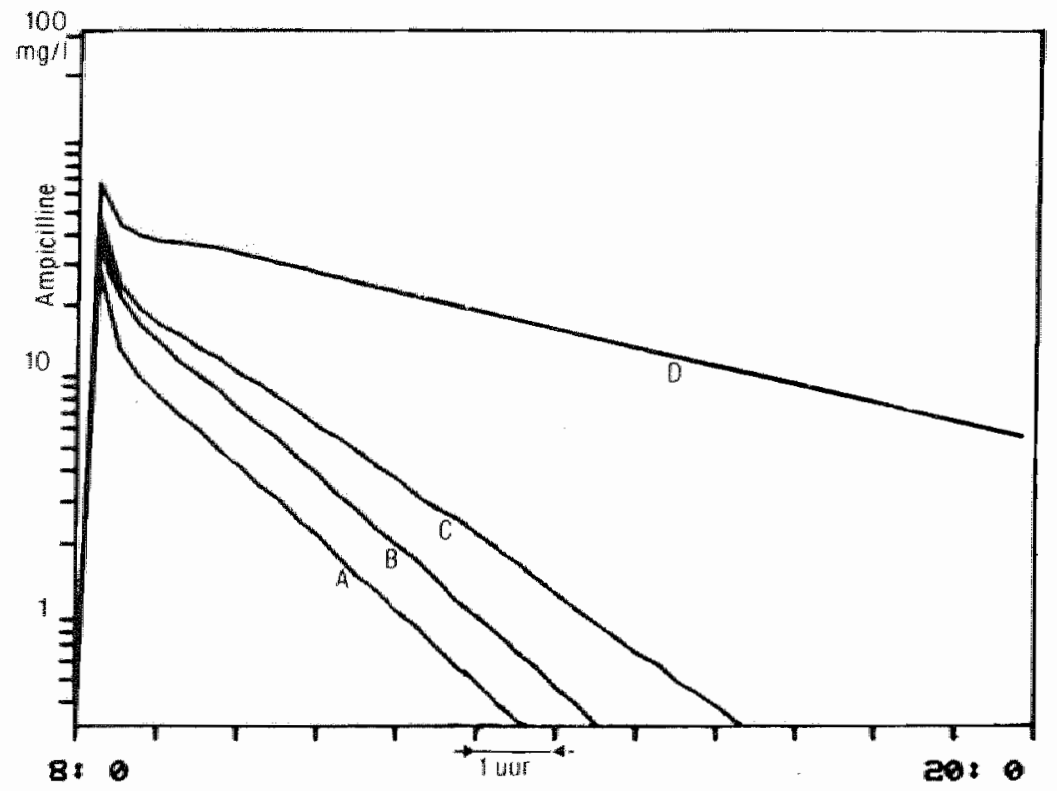

Figutr 7.3 : Het concentratieverloop van ampicilline in het plasma bij 4 verschillende proefpersonen:

\begin{tabular}{|c|c|c|c|c|c|c|}
\hline proetpersonen & doser & ing & $\begin{array}{c}\mathrm{C}_{\mathrm{o}} \\
(\mathrm{mg} / \mathrm{l})\end{array}$ & $\begin{array}{c}t \cdot 2 \\
(m+n)\end{array}$ & $\begin{array}{c}V_{d} \\
(1 \text { ter })\end{array}$ & $\begin{array}{l}\text { klaring } \\
\text { (1/min) }\end{array}$ \\
\hline a. volwassene $75 \mathrm{~kg}$ & $500 \mathrm{mg}$ & i. . . & 18 & 60 & 27.8 & 321 \\
\hline b. neonaat $4.5 \mathrm{~kg}$ & $50 \mathrm{mg}$ & i.w. & 30 & 60 & 1.67 & 19 \\
\hline c. 80 -jarige & 500 me & i...v. & 30 & 80 & 16.7 & 144 \\
\hline $\begin{array}{l}\text { d. mlerfunctie= } \\
\text { stootnis }\end{array}$ & $500 \mathrm{mg}$ & $i . v$. & 48 & 270 & 10.4 & 28 \\
\hline
\end{tabular}

1) patientfactoren $\mathrm{Pg}(\mathrm{GFR})=0.5(6 \%$ en $\mathrm{Pl} 2=0$.

umbryo en foetus (2.1) en over koorts en infectles en ontstekingen (3.1). zowel de wersie MACDops (in het Engels maar met beperkte grafische outputmodellikheden) als MACDOPEX (in het Nederlands en met kwalitatief betere grafische mogelijkheden) zijn door vele studenten bij hun studie gebruikt.

De aspirinecasus stimuleert de studenten na te denken over opnamemechanlsmen in de mag en de invloed van andere oraal ingenomen voedingsstofen of geveesmlddelen die de $\mathrm{pH}$ van de maag en do darm bermuloeden.

De ampictllinecasus geeft de studenten inzicht in de begrippen half- 
wardetijd en verdelingsvolume.

Studenten gebruiken voor experimenten niet alleen geneesmiddelen als Aspirine ${ }^{R}$ en ampicilline mat ook diazepan, lidocaine, amphetamine en penicilline e.d. Veelal experimenteren studenten met de doseringsschema"s mar ook testen $2 i j$ de mogelijkheden utit van grote doses. De studentem worden door het programma geatcendeerd bij een overschrijding van de maximale coegestane dosis. Het computersimulatieprogramna controleert of de plasmaconcentraties niet (te) hoog worden en inakt, indien dit wel het geval is, de studenten hierop opmerkzaam.

De casuistiek is door $H$. Thijssen van de capaciteitsgroep farmacologie ontworpen en ultgetest. MACDOPE is nu door angeveer 150 studenten gebruikt. Het is opgenomen in 3 blokken en over 13 periodes verspreid cussen 1979 en 1982 gebruikt door groepen van 4 tot 20 studenten pur periode. Het model is in dit proefschrift zodanig ontleed in $z$ in wsumtiële onderdelen dat met een geringe tijdsinspanning het model ander het RL-computersimulatiesysteem in het onderwijs kan worden opgenomen.

\section{Referenties}

Bloch, R., D. Ingram, G.D. Sweeney, K. Ahmed, C.J. Dickinson,

MACDOPE: a simulation of drug disposition in the human body.

Mathematical considerations. J.Theor.Biol. 87, 211 (1980).

Ingram, D., C.J. Dickinson, J. Saunders, M. Sherriff, R. Biloch, G. Sweeney, K. Ahmed,

Application of a pharmacokinetic simulation program in pharmacy

courses. Comput. Educ. 3, 335 (1979).

Lammers W., F.A. Nelemans, Th.J. Bouwman, J. wan Noordwijk, l. offer haus, W.M. Rosinga, A. Vermeulen (red),

Algemene farmacotherapie. Stafleu's Wetenschappelijke Uitgeversuij.

B.V. (1980) Leiden. 4e druk, deel. I \& II.

MACDOPE,

MACDOPE, computer simulation of pharmacokinetics. Mannual, Hamilton, Canada (1977).

Saunders, L.. D. Ingram, C.J. Dickinson, M. Sherriff,

A comprehens ive computer simulation of drug metabolism and pharmacokinetics . Comput.Educ. 6, $243(1982)$.

\section{Literaturijist}

Argenio, D.z. A , A. Schumitzky,

A program package for simulation and paramker estimation in

pharmacokinetic systems. Comp. programs Biomed. 9, 115 (1979).

Bozler, G., G. Heinzel, F. W. Koss, M. Wolf,

Modelentwicklurg in der Pharmakokinetik (Teil I, 11, 111, IV, V),

Arzneinituel Forsch./Drug Res. 27, 897 (1977).

Danek, A. ,

The use of computers in pharmacokinetics. Int.j.clin. Pharmacol. 16,

345 (1978). 
Gomeni., R., C. Goment,

Awromod: A polyalgorithm for an integrated analysis of linear pharmacokinetic models. Comput. Biol.Med. 9, 39 (1979).

Johnson, F., C.G. Wilison,

A microprocessor-based simulator for teaching pharmacokinetics. Br.J.Pharmacol. 67, 502p (1979).

Kahn, N., J.T. Bigger,

Instruction in pharmacoknetics: A computer-assisted demonstration system. I.Med. Educ. 49, $292(1974)$.

Krauer, B., F. Krauer,

Drug kinet ics in pregnancy. Clin. Pharmacokinet. 2, 167 (1977).

Neumann, M.

Simulation on a digital computer. Simulationsmethoden in der Medizin und Blologie, Workshop. Springer Verlag Berlin. (1977).

Notari, R.E.,

Btopharmaceutics and pharmacokinetics. Marcel Dekker, New York (1975).

Saunders, L., M. Sherriff, J. Dickinson, D. Ingram, MACDOPE, an interactive computer program for the silmulation of

pharmacokinetics in the human. J.Pharm. Pharmacol. 30, 93P (suppl.) (1978).

Struyker Boudier, H.A.J.,

Computermodellen als thulpmiddellen bij farmacotherapeutisch onderzoek. MIC 1978. Verslag van het eerste medisch informatica congres, CMBIMIM, 281 (1978). (Red. A. Hasman). 
HOOFDSTUK 8

Computersimulat ieprogramma ANAMNESE

Onderwijsdoel

Het computersimulatieprograma ANAMNESE is speciaal ontworpen on studenten de gelegenheid te geven zich te trainen in het opnemen van de anamnese bij een willekeurige patiënt met een bepald ziektebeeld. Voordat de student een anamnese bij een echte patient af gat nemen wordt hem hier een kans geboden de anamnese te leren overzien bij willekeurige ziektebeelden. Er kan met dit programa op een eenvoudige (en goedkope) manier een arts-patient ongeving worden gesimuleerd (Gerritsma en Smal, 1979). Is een bepalde computersimulatiepatiënt niet relevant of afgewerkt, dan kan direct een andere pacient worden uitgekozen. De student kan eenvoudiger dan bij een gewone simulatiepatiënt gebruik maken van het direct toegankelijk patientenbestand van het ANAMNESE programma. Daarnaast kan een student gebruik maken van dit programma op het moment dat hij er aan toe is.

Het programma ANAMNESE laat de student kennis maken met de klassieke opbouw van de anamese, warbij voorkomen wordt dat vragen worden gesteld gericht op een voorkeurshypothese. Andere manieren bit het opnemen van een anamese worden nadrukkelijk niet uitgesloten bij het hanteren van dit programma. Bij het programma wordt de nadruk evenwel niet gelegd op probleem oplossen maar in het krijgen van een compleet averzicht van de anamnese. Het programma is ingedeeld en gebaseerd op principes volgens het leerboek der anamnese en der fysische diagnostiek van Formijne en Mandema (Formijne en Mandema, 1976). Belangrijk volgens deze methode 15 dat de student allo cract doorloopt alvorens hij (een) voorlopige diagnose(s) formuleert. Bij de patient dient eerst de speciele anamnese te worden a $\mathrm{fgehandeld,}$ gericht op de klacht war de patient mee kont. Vervolgens wordt de patient uitvoerig (en van top tot teen) uitgevraagd. Er blijtt overigens ruinte voor andere methodes voor het opnemen van een algemene anamese indien de docent dit wenst.

Er is bij dit programma verder nog een systeem van boodschappen of berichten op bepalde momenten, dus var begeleiding (tutorlall). Tevensi beschikt het programma over een systeem wan zelftest vragen die beantwoord dienem te worden alvorens verder te gaan. De resultaten darvan 
komen aan het eind van een programasessie bij de evaluatie wan een patient weer terug.

Algemene methode die an het programma ten gronds lag ligt.

Het computersimulatieprograma ANAMNESE is oorspronkelijk ontwikkeld In Utrecht bij de Rijksuniversiteit Utrecht (Min, 1978; Min en Ephran, 1979) op het Instituut voor Nucleaire Geneeskunde in samenwerking met de Kinlek voor Inwendige Geneeskunde van de Medische Faculteit, Academisch Ziekenhuis Utrecht (AZU). Het project "Ontwikkelen wan een zelfstudieprograma voor differentiall onderzoek" waruit dit ANAMNESE programa voortkwan dlende t.b.w. een inventarisatie van de mogelijkheden die de computer kan bieden bij de differentiali diagnostiek (Raus en Raus, 1974).

Het programina is niet gebaseerd op een wiskundig model zoals andere hier beschreven computersimulatheprogramma's. Het laat studenten vrij on die vraag te stellen aan de computersimulatepatiënten die zij zelf nodig vinden. Het programa heeft op dit moment 600 verschillende vragen in een wagenbestand verdeeld in 11 hoofdstukken (tracti). In de onderstaande lijst gtaan de belangrijkste thema's (trefwoorden) die kunnen worden uitgevraagd bij het opnemen van een anamese.

1. Algemene klachten: atek, lusteloos, moe, koorts, eetlust, dorst, gewhehtsvenderingen, transpireren, jeuk, vaibaarheid voor infect res.

2. Tractus circulatorius: kortademigheid, aantal kussens, dikke enkets, "s nachts plassen, pin op de borst, hartkloppingen, Langame hart-

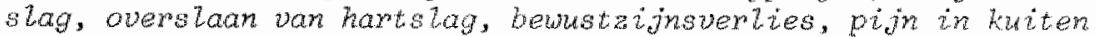
bij het lopen, koude handen of weten, dikke pijnitike benen, opun benen, verhoogde bloeddruk, dieet bi.j zwangerschap.

3. Tractus respiratortus hoesten, stijm opgenen, bloed ophoesten, pirpende ademaling, Kortademigheid, valk verkouden, hoovkoonts, keelontateking, hesheid, pijn op de borst.

4. Tractus digestivus: stinkende adem, pijntigke mondkoeken, tandom -

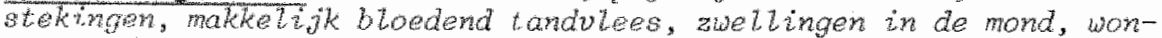
den in de mond, plintijke tong, verdikkingen in de tong, droge

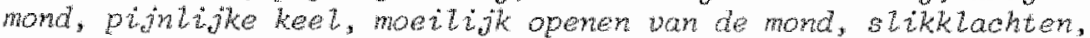
prop in de kel, vaak verolikken, niet zakken van voedsel, ping biy stikken, ping in de buik, zumbranden, overmatig vocht in de mond, boerien, vodselintolerantie, misseligheid, braken, verstoppinger, diarhee, ontlasting, aanbeien, ge be huid of ooguit.

5. Tractus urogentalis: urineerpatroon, veranderingen in winepatroon, pin bif urimeren, laten lopen wan de plas, mictie, persen bij urineren. stappe straal, nadruppelen, afbreken ian de straal, niet voelen aankomen van de plas, vreernde klewr, vies rukend, bloed in de urine, pijn in de zij, menstruatie, vaginate afscheiding, aratal knderen, seer ware kinderer bij de geboorte, impotent. 
6. Tractus locomotorius: pun in de gewmehten, stiffheid, pijm in de nek, mopijin, beuegingsbeperkingen vam de rug, verkmoming van de rug, ping in axmen, pign in benen, knachtsuerlies in anen en benn, pijn in de botten.

7. Tractus haemopoeticus: bleke hadsklewr, rode huidsklew , blawe plekken, bloedwitstontingen, hid- of sitimbliesbloedingen, nabloeden üt kleire wondyes, nabloeden bij kies-aftandtrekken of bit; bevalizingen, klierawellingen.

8. Endocrien systeen: whellingen in hals, kowwiligheid, sleart verdragen van de warmte, norvositeit, dmift- of hinlbien, tritten van de handen, butitensporige haamitual of hargroet, toonhorgte van de stem, veranderingen in mat van (hand sohnenen.

9. Centraal zenuwselse 1: gezichtswemogen, aurte vtckken woo de ogen, dubbel zien, pion in beide ogen, gehoom, norpijn, oorutizu.

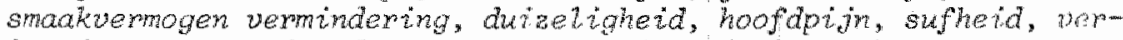
lamingen, tastzin, doof gevoel of prikkelingen of krampen of Rrachtoverties in hander of voeten, onwitlekeurige bewegingen, spraakstoornissen, toevallen, slaapstoornissen, somber gestema", arift- of huilbuien.

10 Huid: huidafwijkingen.

11 Verdere gegevens: familie, eetgewoonten, roken, dminken, medicijngebruik, hobby's, gezin, familie-omstandigheden, beroep, vroegere ziekten.

Elke klacht uit deze lijst kan verder meer of minder gedetailleerd worden uitgevraagd met vragen als:

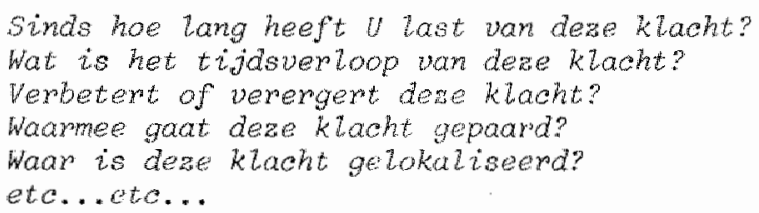

Het programma kan putten wit 2000 à 3000 verschillende antwoorden die zijn opgeslagen in een antwoordenbestand. Een patlënt is dan vast omschreven als elke vraag naar één antwoord wit dit antwoordenbestand refereert. Deze data is de basis van een patientencasus.

op dit moment wordt het simulatleprograma aangeboden met 8 verschlllende patiëntencasus (Handleiding ANAMNESE, 1982). Deze casuistiek is m.n. ontwikkeld in het kader van het onderwijsblok over kortademigheid en pijn op de borst (blok 3.3), vandaar dat het accent hiter wat nadrukke1.jik Iigt op klachten over pijn op de borst, terwijl het vragenbestand verdergaande mogelijkheden biedt.

1. Vrouw van 70 jaar, weduwe. Klacht: pijn op de borst. Diagnose: rheumatoide arthritis, angina pectoris, ulcus duodeni.

2. Man van 48 jaar, jarenlang bakkersknecht, sinds kort bankemployé, getruwd. Klacht: pijn op de borst. Diagnose: hyperwentilatiesyndroom, cesophagusspasmen.

3. Vrouw wan 35 jaar, parttime ponstypiste, gehuwd. Klacht: benatuwdheid mer pijn. Diagnose: longembolie. 
4. Man van 30 jaar, lasser, vrijgezel. Klacht: pijn op de borst. Diagnose: syndroom van Tietze.

5. Man van 70 jaar, weduwaar, vroeger elgenaar wan slagerij. Klacht: pljn op de borst. Diagnose: angina pectoris.

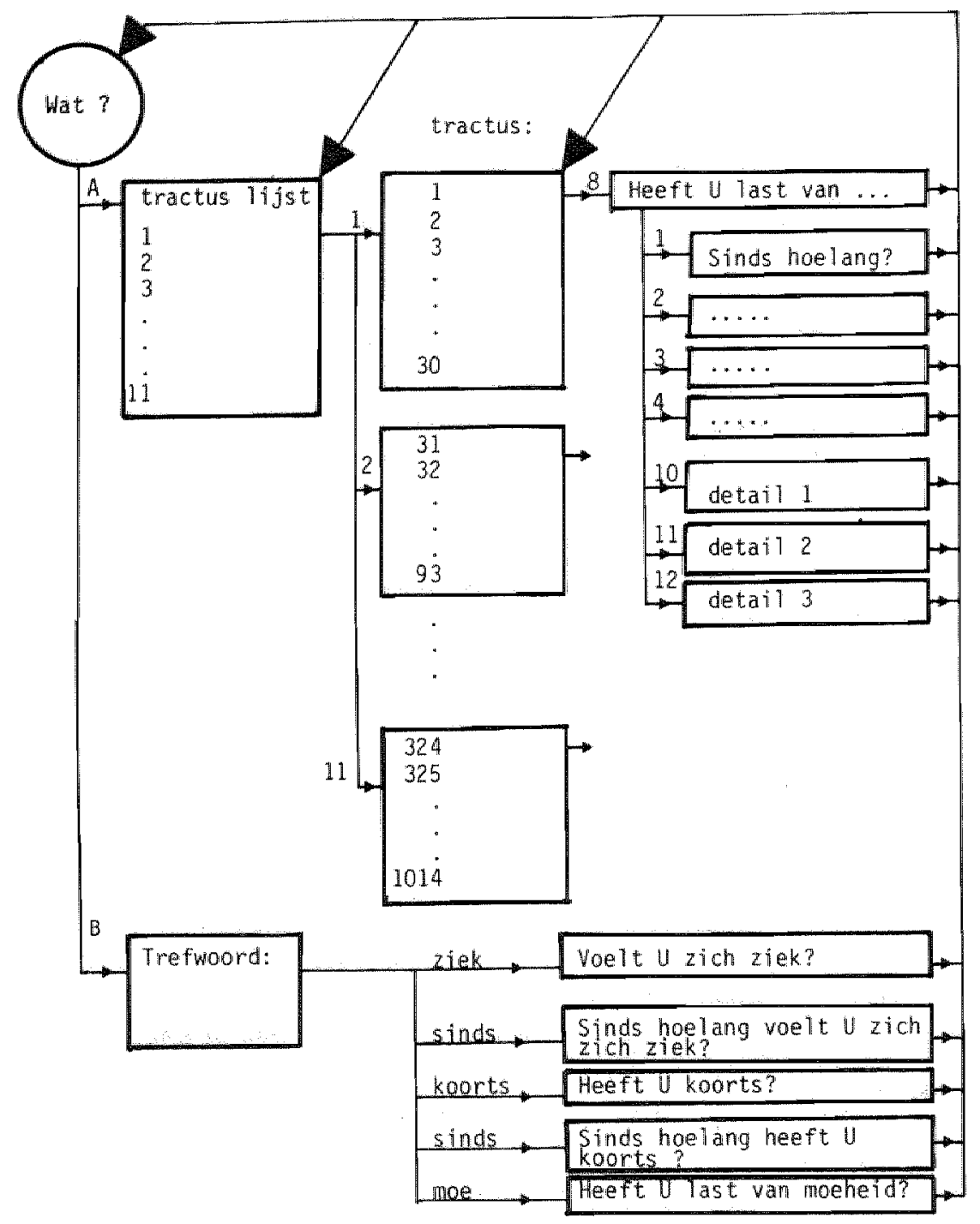

Figuur 8.1: Twee manieren waarop vragen gesteld kunnen worden in het programma ANAMNESE.

Methode A: Kiezen van vragen uit een aangeboden hoeveelheid. Methode B: Zoeken van vragen met een trefwoord.

Beide methoden worden door elkaar gebruikt. 
6. Man van 52 jaar, rij-examinator, gehuwd. Klacht: pijn op de borst. Diagnose: acuut hartinfarct.

7. Vrouw van 40 jaar, huisvrouw en partime serveerster, gescheiden. Klacht: pijn op de borst. Diagnose: reflux oesophagitis.

8. Vrouw van 60 jaar, huisvrouw, gehuwd. Klacht: gewone benauwdhelid. Diagnose: decompensatio cordis links.

Het zijn patiënten met klachten over pijn op de borst of benauwdheld. Patiënt 1 en 2 hebben meerdere ziekten en patiënt 3 tot en met 8 hebben een enkele ziekte. Bij alle patienten geldt dat een voorlopige diagnose stellen pas goed mogelijk is ads de anamese volledig wordt af genomen, vooral bij patiënten met meerdere ziekten. De patiënten en het bijbehorend patiëntenmateriaal zijn ontworpen door een arts en een studentassistente (C. Bleys en G. Jomgmans-Liedekerken). De patiëntencasussen zijn gecest door tientallen studenten en enkele artsen zowel in Utrecht als in Mastricht. De ontwerper van een patiëntencasus hoeft niet bekend te zijn met het programma of geoefend te zijn. Als de ontwerper goed woor ogen staat welke echte patiënt hij als patientencasus wil opwoerem, dan zijn enkele uren tijdsinvestering voldoende voor het ontwerpen van een patièntencasus zijn voorgedrukte vragen- en antwoordenlijsten ontwikkeld. Het invoeren wan de gegevens en het uittesten van het materiaal wordt door derden gedaan. Bij iedere patientencasus dient vermeld te worden welke vragen er essentieel zijn bij de anamnese. Dat zijn vragen die echt gesteld moeten worden om tot eern goede diagnose te kumnen komen aan het eind van het programma verder kan de ontwerper bij zijn patientenmaterial. zelftestvragen opstellen. Deze zelftestvragen kunnen in het programa worden opgenomen om de student op speciale momenten, die uitsiluterd afhangen van de wijze warop een student de anamnese doorloopt, te onderwragen. Dit geeft de mogelijkheld lets te weten te komen over zijn bevindingen tot dan the en hoe de student, gezien de bevindingen, denkt verdet te gaan met de anamnese. In het programma kan de student na elke vraag die hij aan de patiënt stelt een dergelijke mult iple choice vraag of een boodschap verwachten. Op het moment dat het antwoord van de patient op een vrais gekomen is kan de student gevragad worden commentaar te geven. Hicarvor

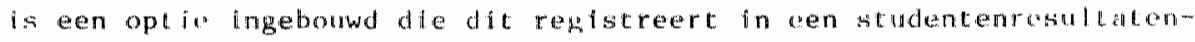
bestand. Voor de student bestat ar voor het stellen van een zeer specifleke vraag nog de mogelijkheid, op elk gewenst momeut, een wribg te zoeken. Het zoeken wan een vraag gebeurt met het intypen van een kort trefwoord of een deel van een woord. Dan worden in het trefwoorden- 
en synoniemenbestand de vragen gezocht die op dat thema betrekking hebben. Op deze manier wordt een lets realistischere manier van vragen stellen verkregen.

If 1 guur 8.1 geeft wan deze methode een beeld. De methode met het zoeken van wragen met een trefwoord (methode B) en die van het stap voor stap kiezen van vragen (methode $A$ ) worden naast elkaar gebruikt tijdens een programma sessie.

\section{Programiabeschrijuing}

Het howforogramma ANAMNESE is opgebouwd uit een tiental versch llende opties (modes) en comminiceert darwoor met 8 databestanden met gesorteerde gegevens. Twee hulpprogramma"s zijn daarbij ontworpen on deze databestanden te onderhouden, wit te breiden en om listings wan hun inhouden te maken. Zie appendix 8.1 .

Het anamneseprogramma kent in total ongeveer 600 vragen die elk een uniek nummer bezitten. Deze vragen zijn verdeeld in 1 l. hoofdstuken, dit $x$ ijn 9 tracti en 2 hoofdstukken van algemene adrd. Zie appendix 8.2 . Elk hoof dstuk c.q. tractus kent hoofdklachturagen (in totaal 143) en detailvragen over deze hoof dklachturagen (in totaal 405 ). Het merendeel van deze vragen heeft een volledig elgen vragtekst in het vragenbestand warbij het indexnumer in dat vragenbestand owereenkomt met het unieke nummer wan de vraag (in totaal 337). De overige vragen, detalivragen, worden qua tekst samengesteld uit delen van de hoofdklachtvragen (in het totaal 222 type $1,2,3$ of type 4 - vragen). De detailvragen van het type $1,2,3$ of 4 kunnen wat betreft vraagtekst geheel en all worden samengesteld wit gegevens wan het vragenbestand van een hoofdklachtraag en maken dat dit vragenbestand la antal ongeveer de helft (326) kan zijn wan het aantal vragen dat in werkelijkheid in het totaal. gesteld kan worden. Zle appendix 8.3. Een belangrijk gedeelthe van de totale hoeveelheid gegevens over én patiënt bij dit programma zijh de antwoorden die bij de vragen horen. De opbouw, de indeling. en de notat iew ize van het vragenthestand is met een voorbeeld uit het hoofdstuk agenent klachten en tractus clrculatorlus als volgt: Algemeno himoldk tacheragen:

llaed 11 lasib van lubeloushe id? vil

Heeft U last van moeheid? v12

Heeft U last van koorts? v 14

Heeft $U$ in het verleden last wan koorts gehad? 
en hoofdklachtenvragen uit de tractus circulatorius:

Heeft U last van dikke enkels?

v39

Moet U 's nachts wel eens plassen?

$\times 41$

Heeft U last van pijn op de borst? $\$ 43$

Heeft $U$ last van pijn op de borst gehad in het verleden? $\$ 57$

Bij al deze hoofdklachtvragen is het mogelijk neer detalls te wragen over een dergelijke klacht zoals bij vio:

Sinds hoe lang heeft U last van lusteloosheid? $(i=364)$

(cype 1)

Wat is het tijdsverloop van het ontstaan wan de luste-

loosheid? $(i=365)$

(type 2)

en:

Welk deel van de dag heeft 0 last wan lustelloosheid?

$(i=11)$

(type 5)

Bij v43 en 457 horen detaillvragen:

Sinds hoe lang heeft 0 last van pijn op de borst?

$(i=391)$

(type 1)

Wat is het tijdswerloop van ontstaan van de pijn op

de borst? $(i=392)$

(type 2)

Verergert of verbetert de pijn op de borst? $(i=393)$

(type 3)

Waarmee gaat de $p i \mathfrak{i} n$ op de borst gepaard? ( $i=394)$

(type 4)

en de detallvragen van het type 5:

Hoe valak heeft $U$ klachten over pijn op de borst?

144

waar is of was deze pijn op de borst gelokaliseerd?

$\times 46$

Wat is of hoe was de aard van deze pijn op de borst?

w47

Stralt of straalde deze pijn op de borst uit?

v48

Hoe lang durt of durrde deze alanval van pijn op de

borst?

$v 49$

Treedt of trad deze pijn op de borst op bij inspanning? v50

Gat of ging deze piln op de horst over in rust?

v 51

Gat of ging deze pijn op de borst over met Nitrobaat?

Hoe lang na Nitrobaat ${ }^{R}$ gat of ging deze pijn op de

borst over?

staat of stond deze pijn op de borst in verband met

hoesten, koude, ademhaling, emoties, bukken of

plat iliggen?

054

Staat of stond deze pijn op de borst in verband met de ademhaling? 
Start of stond deze plin op de borst in verband met hoesten?

en spectaal alleen bij 457 dan nog:

Hoe lang geleden had U die klachten over pijn op

de borst?

Met betrekking tot de aard van de klachten ower pijn op de borst en de ard van de klachten over pljn op de borst die de patiënt vroeger had wordt in dit programma wanwege de onoverzichtel ljkheid die dan zou optreden meestal geen onderscheid gemakt.

In de klachten die als hoofdklachtvraag zijn opgevoerd onderscheidt het programa de klacht die de patlënt nu heeft (rotaal 127), de klacht die de patient uroeger had (totaal 11) en een aantal vragen die in het programma (c. $q$. in de rij met vragen) met cen trefword worden aangegeven (tocal 5) zoals:

Op hoeveel kussens sllapt U? บ38

Hoe is Uw ontlasting? v158

Hoe is Uw urinepatroon? v169

De antwoorden in het antwoordenbestand zijn opgedeeld in categorleën, warbij het overgrote deel van de antwoorden behoort tot de categorie wan vrije antwoorden. De ontwerper van een patient zal altijd behoefte houden om, buiten de grote hoeveetheden antwoorden die al in het antwoordenbestand zijn opgenomen, eigen antwoorden van de patiënt te formleren, geheel naar eigen inzichten. Een dergelijk antwoord wordt dan toegevoegd aan het antwoordenbestand en krijgt dan zijn eigen, nog niet bestaand indexnummer.

Dre indeling en de notatiewijze van deze (in total lo) categorleën is as volget.

Categorie korte antwoorden:

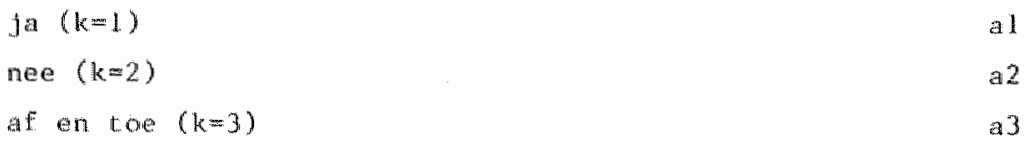

Categorle antwoorden op een "sinds-hoe-lang-vraag":

op dit moment $(k=5)$

as

sinds enicele seconden $(k=6)$

a6

sinds oen halve minuut $(k=7)$

al 7

sinds een minuut $(k=8)$

etco. 
Categorie antwoorden op een "warmee-gepaard-vruag" *

met niets gepaard $(k=85)$

a 85

met hartkloppingen $(k=86)$

a186

met hoesten $(k=87)$

met pijn op de borst $(k=88)$

a 88

Categorie algemene antworden:

ja, zowel bij wast als uloeibar voedse $1(k=427)$

ja, speciaal spruitjes geven slikklachten (k502)

de pijn straalt uit nar de schouder, de armen en

naar de rug (k333)

Zo kunnen we ervan uitgaan dat een patient, afgezien van zijn persoonlijke gegevens zoals naan, geslacht, nationaliteit e.d. door 600 antwoorden bepaald is en vast ligt als casus in dit anameseprogramma. Het is bij deze opzet met vraag en antwoord databanken niet noodzakelijk de hele vraag en het hele antwoord op te slaan maar er kan worden volstaan met de data-opslag van de index $k$ van het antwoord $a_{i j}$ in een array met een grootte van 600 warbij de index overeenkomt met de vraag $v_{i}$ en index $i$ uit het vragenbestand.

Een ement uit dit patiëntenbestand A tat antwoord a ${ }_{i j}$ bevat wordt als volgt gedefinieerd:

waratij

en

en

en $A$ een array

Dit antwoord a $a_{j}$ wordt an de student getoond als hif patient pj de vragg $v_{i}$ steltit.

Een patient $p_{j}$ heeft bij dit programma niet alleen gegevens opgeslagen in het bestand $A$, er is ook nog een bestand $\mathbb{B}$ warin allerlei persoonlijke gegevens zijn opgeslagen, die niet zijn te coderen zoals nam, nationaliteit, vroegere ziekten, medicijngebruik, gewicht, hobby's, etc. Als patient jis $p_{j}$, dan bevat $B$ informatie $b_{1 j}$ dile als volgt wordt gedefinieerd:

$$
b_{1 j}=B\left(p_{j}, w_{1}\right)
$$

waarbij

$$
\begin{aligned}
& 1 \leq \mathbb{1} \leq 20 \\
& 1 \leq j \leq 10 \text { of meer }
\end{aligned}
$$$$
\left(w_{i} \neq v_{i}\right)
$$

ein

en $B$ een bestand $1 s$ dat 20 gegevens per pattënt $\mathrm{Ph}_{j}$ kan bevatcen. 
Deze gegevens b lif $_{\text {f }}$ worden aan de tudent getoond als hij de voorgeschledenis van een patjünt vraagt ( 9 stuks) of kiest uit een van dc 11 afzonderlljk te kiezen opties.

De persoonlljke gegevens van patient 2 ( 22 ) wien er als volgt wit. Voorgeschiedenis:

Geslacht: man

Leett 1 jo: 48 jaar

Woonplates/nationaliteft: nederlandse

(1=1) b 1,2

Burgerlljke staat: gehuwd, 2 kinderen

$(1=2) \quad b \quad 2,2$

verwezen door: hutsarts

Redenen werwijzing: pijn op de borst

$(1=3)$ b 3,2

Hoofdklacht: pijn op de borst

Gewicht: $70 \mathrm{kllogram}$

$(1=4)$ b 4,2

$(1=5)$ b 5,2

Lengte: $170 \mathrm{~cm}$

en Medicijmen: geen

Beroep: bankemployé

Vroegere ziekten: 15 jaar geleden maagoperatie

wegens maagbloeding

Zlekten in famillie: geen

Speciale reacties op bepaalde medicijnen: geen

$(1=6) \quad b 6,2$

$(1=7)$ b 7,2

$(1=8)$ b 8,2

$(1=9)$ b 9,2

$(1=12) \quad b_{12,2}$

$(1=13) \quad b, 3,2$

Gezinssamenstelling: vrouw en 2 kinderen

Woonomstandigheden: galerijflat

Hobby's: geen

Allergieën/huidziekten: geen

Essentiële vragen: $32,43,119,293,1007$

Diagnose: hyperventilat lesyndroom, oesophagus-

$(1=14) \quad b_{14,2}$

$(1=15) \quad b_{15,2}$

$(1=16) \quad b 16,2$

$(1=17) \quad$ D 17,2

$(1=18)$ b 18,2

$(1=19)$ bi 19,2

$(1=20) \quad b_{20,2}$

$(1=10) \quad{ }_{10,2}$

spasmen, psychosociale problematiek

$(1=11) \quad b_{11,2}$

Het totale gegevensbestand van alle patienten is dan

$$
A\left(p_{j}, v_{1}\right)+B\left(p_{j}, v_{1}\right)
$$

met:

$1 \leq 1 \leq 600 \quad$ (maximum antal vragen)

en

$1 \leq j \leq 10$ of meer (maximum aantal patiënten)

en

(maximum aantal persoonlifke gegevens)

Warbil ap de VAX $11 / 780$ bestand $\Lambda 16$ bit integers en bestand $B$ alphanumer loke kitrakterstrings van maximal 150 byte per gegeven zijn. lien spectale mogelijkhedd bij thet anameseprogramid is het genereren van zelftesturagen die de student tijdens het opnemen van de anamese 
eerst moet beantwoorden alvorens hif verder kan gaan met de anamese. Deze zelftestmogelijkheid kan de student of docent nat believen anof uitschakelen.

Deze programmamogelijkheid is het beste an de hand van een woorbeeld te verduidelijken.

Als een student bif een patiēnt p5 op zijn vragen de volgende antworden krijgt:

$\begin{array}{ll}\text { vraag } 55 \text { het antwoord } A(p 5, v 55) & \text { ja } \\ \text { wraag } 56 \text { het antwoord } A(p 5, v 56) & \text { nee } \\ \text { vraag } 8 \text { het antwoord } A(p 5, v 8) & \text { nee (a2) } \\ \text { wraag } 106 \text { het antwoord } A(p 5, v 106) & \text { soms (a100) }\end{array}$

en de conditie waronder mc-vraag 2 wordt gegenereerd is:

als v8 geeft a2 en v106 geeft allo0 dan mc-vraag 2 .

dan wordt op een gegeven moment de volgende mo-vraag op het beeldscherm getoond:

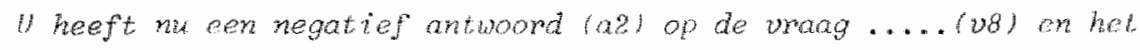

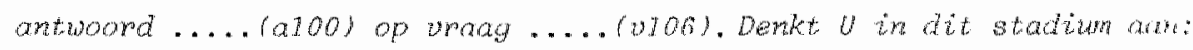
7. Aecompensatio ondis of 2. angina pectonte?

Hiermee is dus de mogelijkheid geschapen on een op mat van de student, en de patiënt waarmee hij bezig is, afgewogen vragen te stellen tijdens het opnemen van de anamese. Dit kan dan een sturende en/of corrigerende werking hebben.

\section{Resultaten}

Met het programma ANAMNESE kan een bijna onbeperkt aantal patiëntencasussen worden ontworpen. Studenten hebben het meeste profljt van de vaordelen van dic programma ANAMNESE als ze een anamese kunnen opnemen bij een (computer) simulatiepatiënt met verschillende klachten. patiënt 1 en 2 zijn patiënten die zodanig zijn ontworpen, dat daarbil meerdere ziektebeelden door elkar heen lopen en warby het van belang is voor de (aanstaande) arts dat hij zich niet laat lelden door een vookkeurshypothese en een belangrijke traccus niet of onvoldoende uitvraagt. De resulitaten die hier uitvoerig worden besproken beperken zich tot 2 voorbeelden van patienten met pijn op de borst. Het overige patiëntenmateriaal is op een analoge wijze opgebouwd. Door het uitgebrelde vragen- en antwoordenbestand van het computersimulac leprogran- 
ma ANANESE kan de casuistiek zich uitstrekken over een groot deel van de gereeskunde.

\section{Rheumatolde arthritis}

Deze patient is 70 jaar en weduwe. Zij heeft klachten over pijn op de borst sinds 3 maanden. De diagnose is rheumatode arthritis, angina peccoris en ulcus duodeni. Voor een juiste diagnose is het van belang dat de student voor wat betreft angina pectoris in ieder geval opnerkt:

- dat de patient pijn op de borst heeft met weken interval tijd

- dat de pijn enkele minuten durt

- dat de lokalisatle achter het borstbeen is

- dat de pijn optreedt bij inspanning

- dat de pijn overgat met Mitrobat ${ }^{R}$

- dat er samenhang kan zijn met emotles

- dat de bloeddruk verhoogd kan zijn

Voor wat betreft ulcus duodend:

- dat er pljn is in de buik

- last van zuurbranden

- het ni.et kunnen verdragen van spruitjes, gebakken spijzen

- dat er pijn is na de maaltj.jden

Voor wat betreft de rheumatoide arthritis:

- dat er pijn is in de gewrichten

- dat er pijn is bij gebruik van de gewrichten

- dat de pljn overgat na ankele uren

Verdere bevindingen bij deze patient a ijn:

pijn op de borst?

jat, sinds 3 maanden

Pijn in de buik?

ja, sinds 3 weken

Zunrbranden?

Overmatig wocht in de mond?

ja. sinds 3 weken

ja, sinds 3 weken

Bueren?

ja, sinds 3 weken

Niet verdragen van bepaald voedsel? ja, sinds 3 weken Verst oppingen?

ja, sinds 3 weken

Pljn in de gewrichten?

Rugpijn?

ja, sinds 25 jaar

ja, sinds 3 weken

Nervositeit?

shapstoornissen?

ja, stords enige maanden

ja. 
Hyperventilatie syndroom, oesophagusspasmen en_psychosociale problemat iek

Deze patiënt is 48 jaar, bankemployé, getrouwd, heeft klachten ovor pijn op de borst sinds 6 maanden. De diagnose is hyperventilatiesyndroom, oesophagusspasmen en psychosociale problematiek. Voor een juiste diagnose is het wan belang dat de student voor wat betreft de psychosociale problematiek opmerkt:

- dat de patient tor een jaar geleden broodbezorger was en nu bankemployé is (na eem lange periode van zelfstandigheid is hij nu, noodgedwongen, werkzaam op een bank en functioneert niet als employé )

Voor wat betreft het hyperventilatiesyndroom:

- dat de patient een vreend gevoel om de mond heeft

- dat er bij aanvallen wan pijn op de borst tintelingen en prikkelingen in handen en voeten $z i j n$

- dat er sprake is van kortadenigheid

- dat er sprake is van duizelingen

Voor wat betreft oesophagusspasmen:

- dat het voedsel niet zakt

- dat de pijn niet verergert, maar wisselend is

Verdere bevindingen bij deze patiënt zijn:

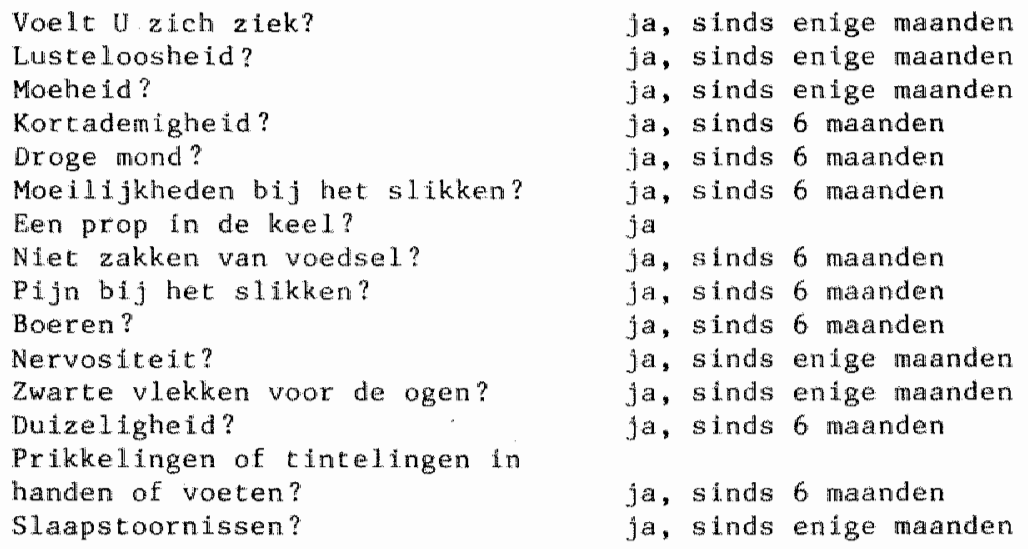

\section{Discussie}

Het computersimulatieprogramma ANAMNESE (VAX 11/780 versie) 1s man de RL in het cursusjaar $1981 / 1982$ voor het eerst gebruikt in het blok "Pijn op de borst" (3.3). In overleg met de blokcoördinator en na 
enkele adviezen van medewerkers uit andere capaciteitsgroepen (m.n. huisartsgeneeskunde) is het programa op detalls nog wat gewijzigd rii.n. In de tractus indeling. Door een studentassistente $1 . s, m$, een medewerker van de capaciteitsgroep Interne Geneeskunde zijn 6 pathentencasts ontworpen wan enkelvoudige zlektebeelden. Tegel ijkert i jd zijn de 2 patienten met verschlllende klachten, die oorspronkelijk aan de Rijksuniversiteit Utrecht waren ontworpen, verder uitgewerkt. Alle paterntencasus zign met de hoofdklacht piln op de borst. In het blok "Pljn op de borst" ligt het accent sterk op het leren omgan met de anannese als belangrijkste instrument voor het stellen van een (voorlopige) diagnose. Het opnemen van een goede, volledige anamnese kan een patiënt wellicht onnodige onderzoeken besparen. Dit programma geeft hierin een trainingseffect. In het kader van deze doelstelling uit dit blok hebben 24 studenten gebruik gemakt van dit programma. Er is met name met patient 1 (een vrouw van 70 jaar met rheutmatolde arthritis, angina pectoris en ulcus duodeni), als met patient 2 (een man van 48 jaar met een hyperventiliatiesyndroom en oesophagusspasmen) gewerkt. Een enkele keer is gebruik gemaakt van de paciënten $3 t / m$ (met een enkellvoudige diagnose) maar daarbij werden studenten dan onder een zekere tijdsdruk geplaatst vanuit een idee van een probleem oplossen binnen een zekere tijd. Het bleek echter zinvoller te zijn vast te houden aan de hoofddoelstelling van het anameseprogramma en de studenten de gelegenheid te geven ruim de tijd te nemen $\mathrm{m} . \mathrm{n}$. bij de patiënten met de meervoudige ziektebeelcien. Dit programma staat toe casuistiek op een breed terrein van de geneeskunde te klezen en even zoveel patièntencasus in ce voeren. Het $\mathrm{RL}$ onderwijssysteem met de verdeling van de stof in thema "s over de verschillende blokken geeft de mogelijkheid ook in het kader van andere blokken dan "Pljn op de borst" patientenmateriaal te ontwikkelen.

\section{Referenties}

Formijne, P., E. Mandena,

Leerboek der anambese en der fysische diagnostiek. Bohn, Scheltema en Holkema, Utrecht (1976) Be druk.

Gerritsma, J.G.M., J.A. Smat,

Realism and adult education: an analysis of the consequences of wo design enproaches for simulation in continuing medical education. Proceedings of the 10th ISAGA conference August 1979 , Leeuwarden (Eds. K. Bruin et al.) Rijksuniversiteit Groningen, Groningen (1979). 
Min, F.B.M.,

Anamnese training; een computersimulatleprogramma. Projectvers lag: Wucleatre geneeskunde, Medische Faculteit, Rijksuniwersiteit Vtrecht, Utrecht (1978).

Min, F.B.M.,

Het gebruik van computer assisted instruction voor het leren overzien van de anamnese. Proceedings Medische Informatica Congres 1979 , Antwerpen. (Ed. J.L. Willems) Afd. Medische Informatica, A.Z. St. Rafaë1, Leuven (1979).

Raus, E., M. Raus,

Manual of history taking, physical examination and record keeping. Lipplncatt Company, Toronto $(1974)$.

\section{Liceracuurlifist}

Bouckaert, A., S. Thiry,

Physiopathological inference by computer. Int.J.Biomed.Comput. 8, $85(1977)$.

Dombal, F.T. de,

Medical diagnosis from a clinican's point of wiew. Mechods Inf. Med. 17, 28 (1978).

Fox, J., $\vec{D}$. Barber, K.D. Bardhan,

Effects of on-line symptom - processing on history - taking and

diagnosis: a simulation study. Int.J.Biomed.Comput, 10, 151 (1979).

McNeil, B.J., H. Sherman,

Example: Bayesian calculations for the determination of the etiology

of pleuritic chest pain in young adults in al teaching haspltal

(part B). Comput.Biomed.Res. 11, 187 (1978).

Nomura, Y., M. Nakamura,

An experimental approach to medical decision problems. Comput. Biomed.

Res. 14, 1 (1981).

Rogers, W., B. Ryack, G. Moeller,

Computer-aided medical diagnosis: Literature Review. Int.J.Biomed.

Comput. 10, 267 (1979).

Schoolman, H.M., R.M. Bernstein,

Computer use in diagnosis, prognasis, and therapy. Science 200 , 926 (1978).

Sherman, H.,

A pocket diagnostic calculator program for computing Bayestan

probabilities for nine diseases with sixteen symptoms (part $A$ ).

Comput. Biomed. Res. 11, 177 (1978).

Taylor, W.C., M. Grace, T.R. Taylor, S.M. Fincham, E.N. Skakun,

The use of computerized patient management problems in a certfying

examination. Med. Educ. 10, 179 (1976).

Wardle, A. "L. Wardle,

Computer aided diagnosis - A review of research. Methods inf.Med.

17,15 (1978). 
HOOFDSTUK 9

Computers imu lat ieprogramma ENZYM

\section{Onderwijsdoel}

Met her computersimulatieprogramma ENZYM kan de student de wetmatigheden bestuderen van de snelheid warmee een eenvoudige enzymreact he volgens de zogenaamde Michaelis-Menten kinetiek verloopt en het produkt uit een substrat onder invloed van een enzym wordt gewormd. Met het computersimulatieprogramma ENZYM kan de invloed van een inhibitor (een reactieremer) of een activator (een versmeller) op de reactiesnelheid worden onderzocht. Niet alleen de enzymeactie als functie van de tijd, maar ook de Linewaever-Burk curve kan worden weergegeven. Zo kan de invloed van de affiniteit en de maximale reactiesnelheid bij $j$ een enzymreactie worden bestudeerd.

Met dit eenvoudige programma leert de student aldoende wetmatigheden die bij schriftelijke presentatie in een handboek -of een zelfs goed gebracht college- vaak niet altijd even gemakkelijk $z i j n$ te volgen (cf. Czerlinski en Sikorski,1976; Mahler en Cordes, 1968).

\section{Model van een enzymreactie}

Het model van het computersimulatieprograma ENZYM bestaat ut een substraat dat door de invloed van een enzym wordt ongezet in een complex van het substraat en het enzym warbij het produkt gevormd han worden. Er kan op het systeem een inhibitor werken die de vorming van het produkt ujteindelijk remt. In principe kan met dit model het effect van zowel een competitieve als een niet-competitieve inhibitor op de enzymreactie worden gesimujeerd. Er kan ook een activator werken op het systeem die de vorming van het produkt extra bevordert. Dat kan doordat er een complex gevormd wordt dat uit het substrat ook het produkt kan vormen. Hier zal alleen de basisreactie van de enzymk Lnetiek worden beschreven (cf. Mahler en Cordes, 1968; Banks, 1975). Voor de uitgebreide reacties wordt verwezen nar elders (Czerlinskil en Sikerski, 1976; Stayton en Froma,1978; Lam,1979).

Deze reactie verloopt volgens het klassieke schema:

$$
E+s \frac{k_{1}}{k_{2}} E S \stackrel{k_{o}}{\longrightarrow} E+P
$$


warbij de volgende variabelen een rol spelen:

[S] substratconcentratie in pmoles/ml met concentratle $S_{0} o p t_{0}$

[E] enzymconcentratie in jmoles/ml met concentratie $E_{0}$ op $t_{0}$

[es] complexconcentratle in umoles/mi

(P) produktconcentratie in umolles/ml

De concentraties bij de reactie verlopen wolgens het stelsel differentiaal wergelifkingen:

$$
\begin{aligned}
& \frac{d[S]}{d t}=-k_{1}[E][S]+k_{2}[E S] \\
& \frac{d[E S]}{d t}=+k_{1}[E][S]-k_{2}[E S]-k_{0}[E S] \\
& \frac{d[E]}{d t}=-k_{1}[E][S]+k_{2}[E S]+k_{0}[E S] \\
& \frac{d[P]}{d t}=k_{0}[E S]
\end{aligned}
$$

Bj.j deze vergelijkingen zal altijd blijwen gelden dat $\left.E_{0}=\llbracket[E]+\mid E S\right\rfloor$ en $S_{0}=[S]+[\mathrm{ES}]+[\mathrm{P}]$.

De snellheidsconstanten $k_{2}$ en $k_{0}$ zijn eerste orde $t i j d s c o n s t a n t e n$ (in $1 /$ sec) en $k_{1}$ is een tweede orde snelheidsconstante in $1 /$ ( $\mu$ moles.sec). De interventies die bij deze basisenzymeactie met het computersimula tieprogramma ENZYM gedadn kunnen worden zijn o.a.:

1. Het vergroten of verkleinen van de verhouding $k_{1} / k_{2}$

2. Het vergroten of verkleinen van de abuangsconcentratie vrij enzyn $\mathrm{E}_{\mathrm{o}}$

3. Het vergroten of verkleinen van de aanvangsconcencratie vrij substraat $S_{0}$

4. Het vergroten of verkleinen van de snelheidsconstante $k_{0}$.

Het is niet moodzakel $i j k$ on deze vergelijkingen met simulatiemethodes op te lossen. Er bestaat ook een analytische benadering voor de berekenling van de verschillende concentraties die alleen geldt indlen $k_{1}>k_{0}$ en $t>1 / \sqrt{k_{1}}$. De vorming van het produkt is een functie van de totale hoeveeltheid substraat, de affintedt en de maximale reactiesnellheid.

Deze analytische oplossing zlet er volgens Michaelis en Menten (1913) als volgt uit:

$$
\frac{d[P]}{d t}=v=k_{0} \frac{E_{d}[S]}{k_{M}+[S]}=\frac{V_{\text {max }}[S]}{k_{M}+[S]} \quad[\mu \text { moles/ml] }
$$

hierbij is

$k_{M}$ de Michatis constante (of affiniteit) $\left(k_{2}+k_{0}\right) / k_{1}$ in fumbles

$v_{\text {max }}$ do maximale reactiesnetheid (of $k_{o} \cdot E_{o}$ ) in umoles/sec

$v$ de react lesnetheid warmee het produkt gevormd wordt in moles/(misec) 
Een karakteristieke witdrukkingsmogelijkheid woor een enzymreactie is de Linewaever Burk curve weergave. Er is een Iinealr verband tussen $1 / \mathrm{w}$ en $1 /[\mathrm{S}]$ wardoor de mogelijkheid bestaat on een enzymeactie en al zijn bijbehorende karakteristieken in een enkele (rechte) lijn vast te leggen. Het smijpunt met de y-as is een mat voor $v_{\text {max }}$ het snijpunt op de $x$-as 1 s een mat voor $k_{M}$ en de helling is een mat voor de verhouding tussen $K_{M}$ en $v_{\text {max }}$ (zie figuur 9.1).

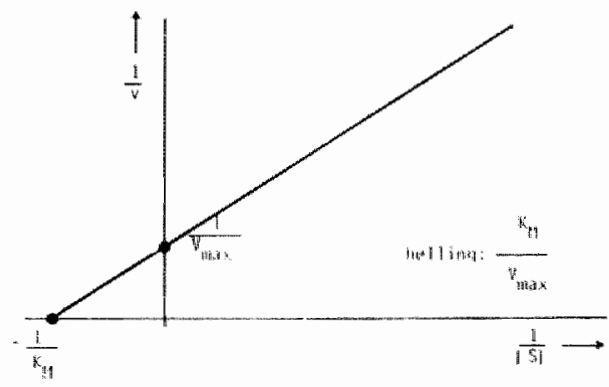

Figur 9.1 : De Linewaever-Burk curve voor een enzymreactie. Een hoge graad van affinitelt van het enzym voor het substraat komt overeen met een "lage" $k_{M}$ en met een kleine helling en een hoge reactiesnelheid.

In principe bestaat bij het RL-computersimulatiesysteem de mogelifkheid het simulatieprogramma ENZYM met deze mogeligkheitu ut te breiden als het in de casuistiek vereist wordt.

\section{Resultaten}

Met het computersimulatieprograma ENZYM $z$ if stimuleren die angeven wat de mogelijkheden zijh bij dit eenvoudig. model. In figur 9.2 is een voorbeeld gegeven van een enzymreactie watrbij de werhouding $k_{2} / k_{1}$ gelijk is aan lo wnoles. Hierbij is te zien dat het substrat $s$ afneemt en het produkt $P$ coeneent. Het complex ES vertoont een maximum. Duidelijk is te zien dat in de scartcase ex en snelle vorming van het complex is en daarmall een langzame Lase warbij de concentratie van het complex langzan daalt en de enzymconcentratie weer op de uitgangswaarde terug kont. Dat laatsce is te verklaren doordat het substraat uitgeput raakt bij dit 


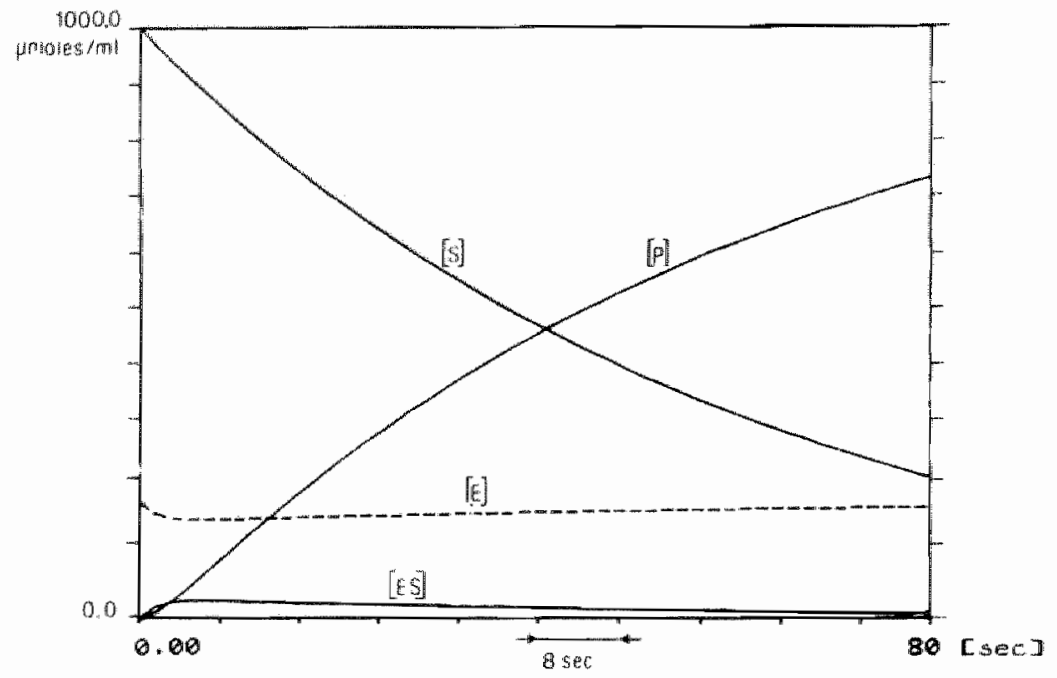

Figur 9.2 : Het concentratieverloop van de klassieke enzymreactie warbfj $S_{O}=1000 \mu$ moles $/ \mathrm{ml}, E_{O}=200 \mu m o l e s / m 1$ en $k_{1}=0.0001 /(\mu$ moles.sec $), k_{2}=0.001 / \sec , k_{0}=0.5 / \sec$.

experiment. Er is in de startiase bij de vorming van het produkt $P$ een dufdelijk buigpunt te zlen dat karakeristiek is voor dergelijke enzymreacties.

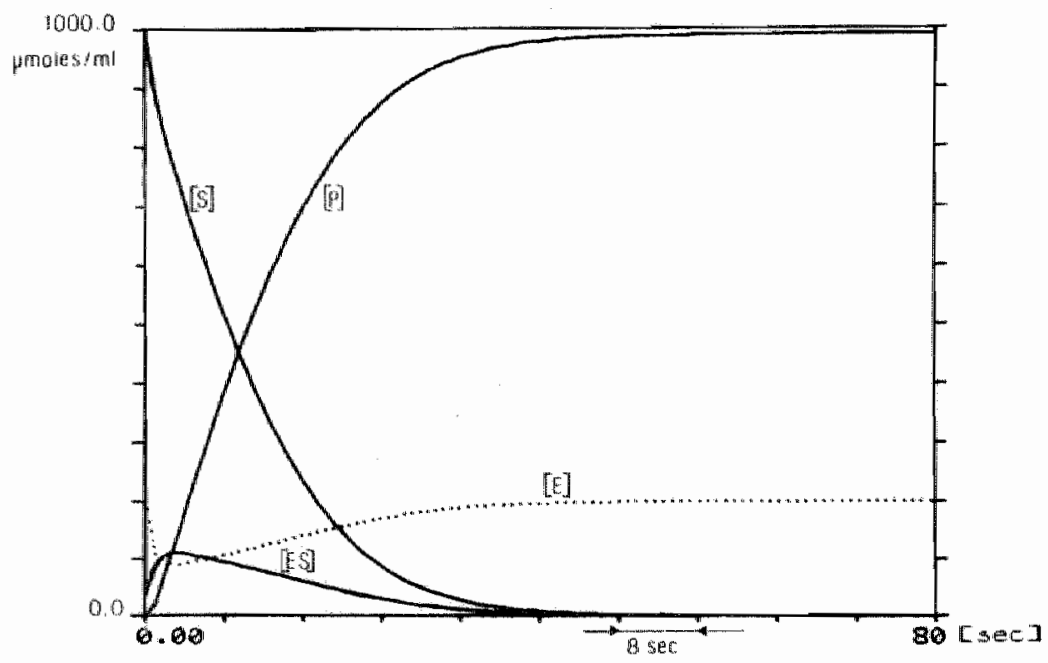

Figur 9.3: Het concentratieverloop van de klassieke basisenzymractie $\left(k_{1}=0.0008 /\right.$ (unoles $\left.\mathrm{sec}\right), k_{2}=0.000125 / \mathrm{sec}$ en met de andere parameters zoals in figur 9.2). 
Een tweede voorbeeld is aangegeven in figur 9.3 van een experiment met een reactie warbij $k_{1}$ is toegenomen en $k_{2}$ is afgenomen. Hierbij is te zien dat de vorming van het complex en het produkt snel gat an de concentratie van het enzym snel minder wordt. Als het substraat is ud tgeput treedt er een rust toestand op warbij de concentrat ie van het produkt gellijk is aan de beginconcentratie van het substrat. De enzymconcentratie is daarbij weer gelijk aan de enzymconcentratie in het begin.

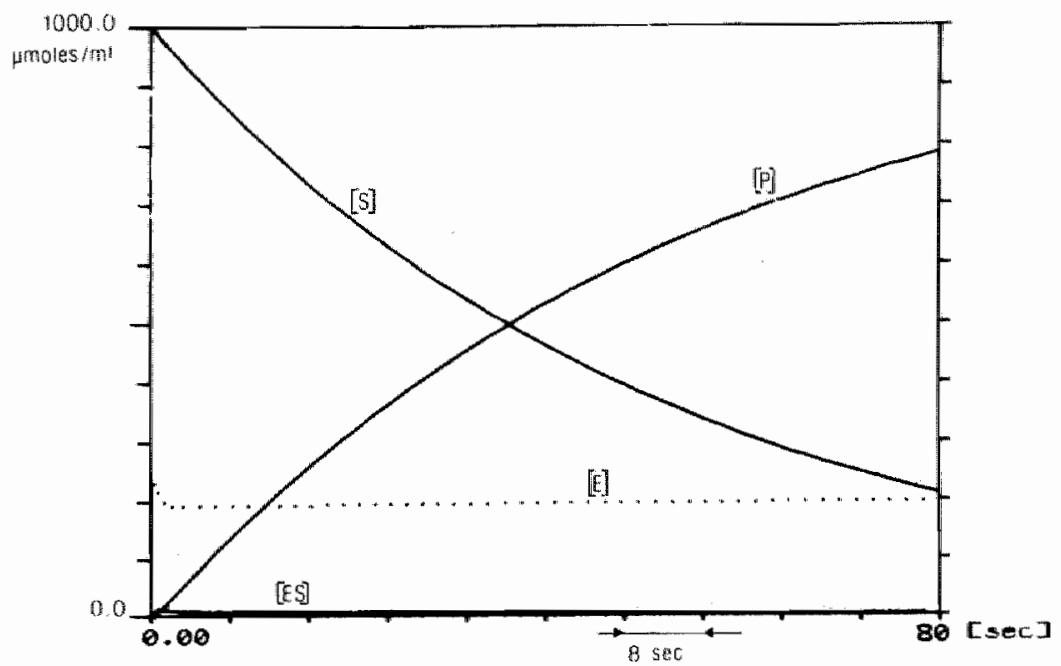

Figuur 9. 4 : Het concentratieverloop van de klassieke basisenzymreactie $\left(k_{0}=2 /\right.$ sec en met de andere parameters zoals in figuur 9.2).

Een derde woorbeeld is weergegeven in figuur 9.4 van een expertment met als ultgangspunt de enzymeactie uit het voorbeeld van figuur 9.2 maar met een hogere factor $k_{0}\left(k_{0}=2\right.$; was 0.5$)$. Herblj 1 s te zien dat de complex concentratie [ES] kleith blijft en de vorming van het produkt darmee zeker niet geremd wordt.

\section{Discussie}

Het computersimulatieprograma ENZYM is recentelijk gereedgekomen en is nog niet daadwerkelljk in het onderwijs beproefd. De casuistiek lk nog niet voldoende uitgewerkt hoewel er in de literatuur voldoende material en voorbeelden voorhanden $z$ ijn om zinvolle experimenten te kunnen aanbieden in thet curriculum. De verwachting is dat, evenzeer 
als op andere universtceiten is gebleken, deze basale enzymkinetiek goed door studenten bestudeerd kan worden uit handboeken maar dat zij een barrière ondervinden tussen de theorie en de expertmentele pratijk. Hietblj kan dit computers linulatieprograma een zinvolje rol spelien. De repregentatievorm van een enzymreacte door middel van een linewaevar Burk curve is nog niet ulgewerkt in dit simulatleprogramma.

\section{Referent}

Bantis, H. T.

Lecture notes in biomathematics. Springer verlag (1975). Coleman, T.G.,

Twenty (mosty physiological) problems that can be solved using

a computer and baslc programing language. University of Mississippi, Medical Center, Jackson, U.S.A. (1978).

Czerlinski, G., J. Slkorski,

Computer-based modelling in the teaching of steady-state enzyme

kinetlcs. J.Chem. Inform.Comp.Sci. 16*30 (1976).

Lam, C.F., A.P. Cross,

A systematic computerized method for building enzyme kinetics models. Comput.Biol.Med, 9, 305 (1979).

Mahler, H.R., E.H. Cordes,

Bastc biological chemistry. Harper \&ow, Waether Hill (1968)

2nd edition.

Stayton, M.M. and H.J. Fromm,

A computer andysis of the validity of the integrated MichaelisMenten equation. J.Theor. Biol. 78, 309 (1979).

\section{Literatumerist}

Alba, S., M. Matsuoka,

Identification of metabolic model: citrate production from glucose

by candida lipolytica. Blotechn. Bioeng. 21, 1373 (1979).

Bhaumik, D., K. Bhaumik, A.K. Ray, B. Dutta-Roy,

On a model and the kilnetlcs of photo-enhanced enzyme reactions.

Bull. Math. B101. 40,719 (1978).

Estreicher, J., C. Revillard, J.R. Scherrer,

Compartmental analysis - II: ACT, a program for compartimentall

model of the generalized Michadi-Menten type. Comput.Biol. Eng. 9, $67(1979)$.

Falriey, J.L., G.L.. Kilgour,

Essent i.als of biological chemistry. Rheinhold Publishing Corp., New York (1966).

Garfinke1, D.*

Computer modelling of metabolic pathways. Trends Blochem.Sci. $6.69(1981)$.

Grindey, G.B., Y.C. Cheng,

Biamedical and kinetic approaches to inhibition of multiple

pathways. Pharmac. Ther. 4, 307 (1979).

Kurganov: B.I.; N.I. Loboda,

Regulation of enzyme activity in adsorptive enzyme systems. J. Theor. Biol. 79, 281 (1979). 
Paletta, B., R. Moeller, H. Trutnovsky, W. Mlekusch, Computer-aided bionedical system analysis in open systems with environment simulation. Experientia 351049 (1979).

Peltersen, N., E.W. Ross jr.,

Mathematical model for enzymatic hydrolysis and fermentation of cellulose by trichoderma. Biotechn.Bioeng. 21, 997 (1979).

Stubblefield, E., C.M. Dennis,

The simulation of thymidine kinase enzyme kinetics in cultured cell using the computer language CELLSIM. J.Theor "Biol. 61, 171 (1976).

Whitehead, E.P.,

The structure of steady-state enzyme kinetic equations: a graphtheoretical algorithm for obtaining conditions for reduction in degree by common-factor cancellation. J.Theor.Biol. 80, 355 (1979). 
HOOFDSTUK 10

\section{Evaluatie en conclusies}

\subsection{Evaluatiegegevens}

In dit hoofdstuk zal getracht worden aan te geven welke de ervaringen met de verschillende computersimulaties zijn geweest. Er zal worden nagegaan

- welke programa"s er zijn gebruikt;

- in we1ke onderwijsblokken programma's zijn aangeboden;

- hoeveel studenten per onderwijstlok gebruik hebben gemakt van de programma"s;

- hoe studenten werken met het RL-simulatiesysteem;

- welke casus studenten gebruiken;

- hore ver studenten ingaan op de aangesneden problematiek;

- wat studenten uit een bepaald onderwijsblok hebben gevonden van een bepald programma ;

- wat de resultaten van de studenten zijn bij de voortgangstoets en bij de bloktoecs op vragen m.b.t. een onderwexp uit de computersimulatieprogramma's.

\section{Onderwijgblokken en gebrulkte_Rrogramma's}

In de wolgende onderwijsblokken zijn tut en met juni 1982 computersimulat leprogramma's opgenomen (indeling studiejaar 1981/82):

In het eerste jaar:

1. 5 Atherosclerose AORTA

In het tweede jaar:

2.1. Embryo en foetus

MACDOPE

2. 3 Keuze-onderwijs

(onderdelen farmacologie, hart en longen) CARDIO

2.5 De volwassene FLUIDS

In het derde jaar:

3.1 Koorts, infecties en ontstekingen

MACDOPE

3.2 Moeheld MACDOPE EN CARDTO

3.3 Kortademigheld, pily op de borst ANAMNESE UT CARTIO

3.5 en 3.6 Keuze-onderwijs (idem als bij 2.3) MACDOPE en CARDIO Deze indeling wan de onderwlysbloken is in de studiejaren $1978 / 79$, $1979 / 80,1980 / 81,1981 / 82$ niet altijd dezelfde geweest. De onderwilsbloknummers in de tabellen zijn in het hiervolgende "verwerkt" tot de Indeling van het studiejaar $1981 / 82$. 


\section{Computers imulateprograma"}

Vanaf de introduct le in mart 1979 van het eerste complete computersimulatleprograma tot juni 1982 is het aantal geregistreerde inschrijvingen ongeveer 400 geweest. In tabel 10.1 is aangegeven hoveel maal een programma door studenten is gebruikt en in het kader van welk onderwhsblok dat is geveest.

Tabe1 10.1 Computersimulatieprograma's an de RL

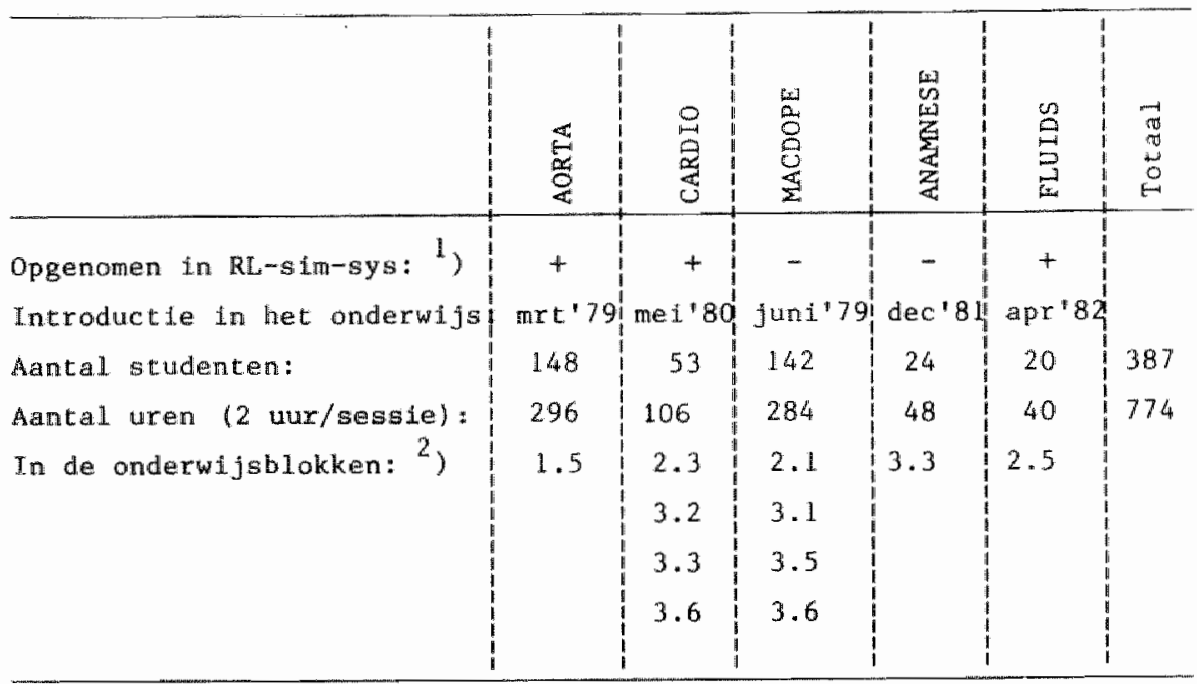

1) Computersimulatieprogramma FARMA en ENZYM zijn nog niet in het curriculum opgenomen, well in het RL-simulatiesysteem.

2) 1.5 (over atherosclerose), 2.1 (over embryo en foetus), 2.5 (de volwassene), 3.1 (over koorts, infectles en ontstekingen), 3.2 (over moeheid), 3.3 (over kortademigheld en pijn op de borst) en $2.3,3.5$ en 3.6 (keuzeblak)

In tabel 10.21 aangegeven hoeveel studenten ex in de Loop van 4 studiejaren per cursusperiode met een bepaald programma ervaringen hebben opgedaan. In het studiejaar $1979 / 80$ en in mindere mate in $1980 / 81$ was computersimulatie nog nfet algemeenbekend als leermiddel of wat er precles mee gedaan zou kunnen worden. Door een gerichte campagne over de mogelijkheden van computersimulatle in het algemeen en de afzonderlithe programma's in het bijzonder nam de belangstelling vanaf het studiejaar $1981 / 82$ sterk toe. Hierbij heeft ongetwijfeld ook een rol gespeeld dat het project computersimulatie in die perfoden over een eigen computersysteem en een spectaal daarvoor ingerichte ruimte kon beschikken. 
Tabel 10.2. Aantal geregistreerde studenten $t / m$ juni 1982.

1. tijdstip

2. progr ammat

3. blok
4. aantal studenten per onderwijsblok 5. aantal uren per groep 6. aantal studenten per groep

i.

2.

3.

4. 5.

6

Studiejaar 1978/79:

1 ant' 79

2 jun' 79

AORTA 1.5

MACDOPE $\mathrm{kb}$ ()

$70 \quad 2$

3

$17 \quad 2 \quad 1$ a 2

Studiejaar 1979/80:

3 sep-okt'79
4 nov'79
5 apr-me i' 80
6 mei-jun' 80
7 mei'so

MACDOPE 2.1

62

2

MACDOPE 3.2

22

2

AORTA $\quad 1.5$

232

2 a 3

MACDOPE $\mathrm{kb}$

$10 \quad 2$

2 à 3

CARDIO $\mathrm{kb}$

42

2

Studiejaar 1980/81:

$\begin{array}{rlllll}8 \text { okt'80 } & \text { MACDOPE } & 2.1 & 22 & 2 & 1 \text { à } 2 \\ 9 \text { okt'80 } & \text { MACDOPE } & 3.1 & 3 & 2 & 2 \\ 10 \text { nov'80 } & \text { CARDTO } & 3.2 & 11 & 2 & 1 \text { à } 2 \\ 11 \text { dec'8.0 } & \text { MACDOPE } & \mathrm{kb} & 11 & 2 & 3 \text { à } 4 \\ 12 \text { apr'81 } & \text { AORTA } & 1.5 & 11 & 2 & 1 \text { à } 3 \\ 13 \text { mei'81 } & \text { MACDOPE } & k b & 3 & 2 & 3\end{array}$

Studiejaar 1981/82:

14 okt. 8.1

15 okt 81

16 nov'81-Feb' 82

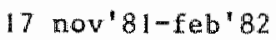

18 nov' 81 -feb' 82

19 now'81-apr'82

20 jant 82

21 mrt-me $i^{\prime} 82$

22 apr' 82

23 apr-mei' 82

24 me il' 82
MACDOPEX 2.1

MACDOPEX 3.1

CARDIO 3.2

CARDTO 3.3

MACDOPEX $\mathrm{kb}$

ANAMNESE 3.3

CARDIO $\mathrm{kb}(2.3)$

AORTA $\quad 1.5$

CARDLO $\mathrm{kb}(3.4)$

FLUTDS 2.5

MACDOPE $\mathrm{kb}$ (3.6)

\begin{tabular}{|c|c|c|}
\hline & 2 & 1 à \\
\hline 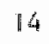 & 2 & $1 \bar{a}$ \\
\hline H & 2 & 2 घั \\
\hline 12 & 2 & 2 a \\
\hline 10 & 2 & 2 \\
\hline 24 & 1 a 3 & $\|$ à \\
\hline 12 & 2 & $2 \pi$ \\
\hline 40 & 2 & 1 à \\
\hline 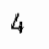 & 2 & 2 a \\
\hline & 2 & $2 a$ \\
\hline & 2 & 2 \\
\hline
\end{tabular}

Total 24 periodes

5 pro- 8 blokken

387774

grama's

1) Het onderwijsblok keuze-onderwijs heeft meestal betrekking op studenten, die een inleiding in de farmacollogie volgen. 
In maart 1979 was het computersimulatleprograma AORTA verplicht en neergelegd in een rooster in het blokboek. In tabel 10.2 is te alen dat 70 studenten (d.1. 100\% van een jaargroepl zijn geweest. In alle andere gevallen was computersinulatie niet verplicht maar werd het woor bepalde gebieden anbevolen of bij bepaalde casuistiek gepresenteerd. B1f twee onderdelen van het keuze-onderwijs in een keuzeblok ( $k b$ ) is in het algemeen voor de hele groep een computersimulatieprograma verplicht. In bepalde gevallen wonden twee verschillende programma's in een blok aangeboden. Overlgens staat het de student vifij on op momten dat hij dat w1 ergens in $z i j n$ studie een computersimulatieprograma te gebrulken. Registratie van die studentenaktiviteiten zijn niet in bovengenoende tabel terug te vinden.

Tabel 10.3 Gebruik van computersimulatieprograma's per jaargroep

\begin{tabular}{|c|c|c|c|c|c|}
\hline -Jaargroep: & $1977^{2)}$ & 1978 & 1979 & 1980 & $1981^{1)}$ \\
\hline $\begin{array}{l}\text { - Totaal aantal } \\
\text { studenten per } \\
\text { jaargroep: }\end{array}$ & $60(100 \%)$ & $70(100 \%)$ & $80(100 \%)$ & $100(100 \%)$ & $125(100 \%)$ \\
\hline $\begin{array}{l}\text {-Aanta } 1 \text { student } \\
\text { dat met prograr } \\
\text { ma"s kennis } \\
\text { heeft gemaakt: }\end{array}$ & $20(33 \%)$ & $70(100 \%)$ & $57(71.3 \%)$ & $53(53 \%)$ & $44(35 \%)$ \\
\hline - Ix gebruik ${ }^{4)}$ & 17 & 53 & 20 & 38 & $44^{5)}$ \\
\hline$-2 x$ gebrulik: & 3 & 12 & 17 & 9 & -- \\
\hline$-3 x$ gebruik: & -- & 4 & 15 & 6 & -- \\
\hline$-4 x$ gebruik: & -- & -- & 3 & -- & -- \\
\hline$-5 x$ gebruilk: & -- & 1 & 1 & -- & -- \\
\hline$-6 x$ gebruik: & -- & -- & 1 & -- & -- \\
\hline $\begin{array}{l}\text {-Gemiddeld aan- } \\
\text { tal keren een } \\
\text { programma ge- } \\
\text { bruikt: }\end{array}$ & 1.25 & 1.34 & 1.81 & $1 \cdot 42^{31}$ & $1.00^{31}$ \\
\hline
\end{tabular}

1) Jaargroep ' 81 heeft pas ếnmal gebruik gemaalkt van een programma.

2) Jatrgroep "77 heeft slechts met twee programma"s kunnen kennis maken .

3) Jaargroep 1980 en 1981 studeert pas 2 resp. 1 jaar aan de $\mathbb{R L}$.

4) Eenmal, tweemaal of meerdere malen één programma gebruiken of meerdere programma"s eenmaal gebruiken.

5) Deze uitsplitsing was alleen mogelijk bij 357 inschriljuingen op naam. 


\section{Computersimulatieprogramma"s per jaargroep}

In de tabel 10.3 is van 5 jaargroepen aangegeven hoeveel studenten er ult een jaargroep computersimulatieprograma's gebruiken of gebruikt hebben gedurende hun studie. Onder een jaargroep wordt hier verstaan de groep studenten die in september wan een jaar met hun studie begint of begonnen is, aan de Rijksuniversiteit Limburg (m.n. de Medische Faculteit).

In 1977 waren dat 60 studenten. Deze groep heeft maat kort gebruik kumnen maken van computersimulatieprogramm's. Alleen het programma AORTA was toen operationeel. In 1978 waren er 70 studenten; in 197980 studenten en in $1980 \quad 100$ studenten dle aan hun studie begonnen. De jaargroep 1981 telde 125 studenten. Deze laatste groep heeft pas énmaal (1n blok 1.5) een computersimulatieprograma kunnen gebruiken (AORTA). Het zal dus duidelijk zijn dat in tabel 10.3 de 5 jaargroepen niet goed onderling vergelijkbaar zijn. Daarvoor zijn er te veel externe factoren die in een jaargroep een rol spelen m.b.t. het gebrulk van een programma in een onderwijsblok van éên bepaald studiejaar. In de berekeningen, m.n. In tabel 10.5 wordt het aantal studenten van een jaargroep in september van het eerste faar op $100 \%$ gesteld. Het antal studenten van een jaargroep schommelt voortdurend. Dat komt doordat er studenten van andere jaren achter blijven en doordat er studenten afvallen. In de cijfers is niet aangegeven het gebruik van de programa's door studenten die niet geregistreerd zijn. In de twee oudste groepen is iedereen met computersimulatie in aanraking gekomen hoewel dat met oude versies van een programma was. Voor de jaargroep 1978 was het AORTA programma verplicht en geschledde nog in grote groepen. Het was toen meer een demonstratiemodel $1 . p \cdot v$. een (ind vidueel) leermiddel. In de 1979 jaargroep hebben studenten gemiddeld 2 mal met een programma gewerkt gedurende 3 jaar van hun studie. Het. ligt in de $11 j n$ van de verwacht Ingen dat de twee jongere groepen dit zullen overtreffen als zij ook 3. jaar meegedaan hebben met het onderwijs. In de 1979 jaargroep is te zien dat enkele studenten 4 tot 6 maal terugkomen om: of eenzelfde programa nog eens (uitgebreider) te doen of om met een ander programma te werken.

\section{Gebruik_van_programma"s_per_groep_studenten}

Vanaf april 1980 tot heden vindt er een systematische registratie plats bij de computersimulatieprogramma"s van veranderingen die de student in 
het model aanbrengt.

Deze gegevens omtrent het "gedrag" yan een of twee studenten aan de terminal gedurende de 2 uur die een sessle duurt zijn zeer moeilijk te interpreteren. Waarnemingen van een studiebegeleider of van cen inhoudsdeskundige zijn zinvoller en beter te incerpreteren voor bepalingen van "het gedrag" van studenten achter de computer.

Tabiel 10.4a. Gemiddeld aantal veranderingen ${ }^{1)}$ per keer per groepje studenten.

\begin{tabular}{lcccc}
\hline Studiejaar: & $1979 / 80$ & $1980 / 81$ & $1981 / 82$ & $\begin{array}{l}\text { aantal interven- } \\
\text { tie mogelijkheden }\end{array}$ \\
AORTA & 13.8 & 10.5 & 10.3 & 4 \\
CARDIO & -- & -- & 12.9 & 8 \\
ELUTDS & -- & -- & 21.1 & 5
\end{tabular}

1) een "veranderlng" impliceert ook graduele veranderingen in de waarde van één interventie.

Tabel 10.4 b Gemiddeld aantal vragen per patiënt per groepje studenten..

\begin{tabular}{lrrrrr}
\hline Patiënt: 2) & 3 & 4 & 6 & 8 & totaal gemiddeld: \\
ANAMNESE: & 59.7 & 77.0 & 57.5 & 33.5 & $65.6 \quad 1)$
\end{tabular}

1) Gemiddeld aantal vragen per patiënt per groep: 65.6 stuks in gemiddeld 49.5 minuten.

2 ) Patient 3 en 4 hebben meerdere aandoeningen, patiënt 6 en 8 hebben één aandoening *

In tabel $10.4 \mathrm{zijn}$ voor 4 programma's toch enkele geniddelden berekend van de aantallen veranderingen die men gedurende één sessie aanbrengt aan het model t.o.v. het aantal mogelljkheden tot interventile in het model. Er bleken studenten te zijn die bulten de voorstellen die ze op papler kregen van alles zelf wilden proberen te veranderen om mar resultaten te zien. Er zijn ook studenten die heel lang aarzelden alvorens ze een parameter anders in wilden stellen mar dat dan consequent en precies deden.

In bepalde jaren is een programma beter uitgewerkt, is er betere casuistiek of is ex meer begeleiding. Dat alles makt dat de cijfers in tabel 10.4 slechts een indicatie zijn en een globale indruk geven. Dit soort data zal in de toekonst ongetwijfeld nog een rol spelen als er meer bekend wordt hoe studenten problemen aanpakken met computersimulatieprogramma's. Heel sterk speelt mee of de student de leerstof, die behandeld wordt in een geprepareerde casus al kan overzien en enigszins 
beheerst. Dit bepaalt mede hoe snel bij besluit een ander probleem anm te pakken dat hem op dat moment in zijn studie wellicht meer anspreakt dan de geboden casuistiek.

Bij het computersimulatieprogramma AORTA (tabel 10.4a) kunnen studenten maar 4 parameters van het model veranderen. Voordat de "guiste" waarde van een parameter is gevonden worden meestal tussenwaarden geprobeerd. In de twee ur dat een sessie durt doen de studenten de casus mec de afgenomen compliantie van de aorta en de casus met een verhoogde perifere weerstand. Het blifkt dat de studenten 10.3 mal (gemiddeld) een parameter hebben veranderd bij het programa AORTA zoals dat in het studiejaar 1981/82 werd aangeboden. Bij het computersimulatieprograma CARDTo Iigt dit in dezelfde arde van grootce (12.9).

Het computersimulatieprograma FLUIDs springt eruic. Dit programma wordt ook gebruikt bij een casus waarbij een complete interventie bestaat uit het veranderen van 3 of meer parameters. Zo dient bij het toedienen van een fyslologisch zout infuus de hoeveelheid water, de hoeveelheid natrium, de hoeveelheid chloor en de tijdsduur van het infuus te worden ingesteld. Bij dit programma was het geniddelde aantal veranderingen per groep per keer nog al hoog (gemiddeld 21.1 maal). De geregistreerde resultaten van het gebrulk van het computersimulatieprogramma ANAMNESE (tabe $10.4 \mathrm{~b}$ ) geven een indruk van het aantal wragen dat een groep studenten per patiëntencasus stelt voordat men een voorlopige diagnose geeft of ophoudt met het programma. Dat blijken gemiddeld 65.6 vragen per graep per patiëntencasus.

Een groep van 2 studenten doet gemiddeld 49.5 minuten over een patiëntencasus bij het programma ANAMNESE.

Waardering (enige preliminaire gegevens).

In bepalde onderwilsblokken worden bij de afsluiting van het blok. in de schriftelifke evaluatle, wragen gesteld over het gebruik van computersimulatieprogramma"s en de wardering wan de studenten betreffende de programma"s.

In het onderwijsblok over atherosclerose (1.5) heeft de overgrote meerderheid wan de studenten dle gebruik hebben gemaakt van het AoRTM programma dit instructief tot zeer instructief gevonden (in 1979/80 $87 \%$ van 23 studenten en in $1980 / 8191 \%$ van 11 studenten). In het onderwijsblok over embryo en foetus (2.1) en over koorts, infecties en ontstekingen (3.1) waren de studenten die met het programa 
MACDOPE hadden gewerkt positief (70\% wan ongeveer 100 studenten) over computers imulatie. Op een wrag warom men niet gewerkt had met de smulat leprogramma"s gaf de overgrote meerderheld van de resterende studenten op dat men geen $1 \mathbf{1}$ d had kumen winden voor computersimulatie (studiejaren 1980/81 en 1981/82).

In het onderwijsblok over de volwassene (2.5), wat het computersimulateprograma Futos voor het eerst is aangeboden in het studiejaar $1981 /$ 82, hebben 20 studenten met het programma gewerkt en deze waren grotendeels neutraal in hun mening met enkele uitschieters naar boven. Over het algemeen kan worden geconcludeerd dat daar waar evaluatievragen waren opgenomen in de programma evaluatle vragenlijst, de resultaten aver ervaringen met computersimulatieprogramma"s positief bleken in dat betreffende blak.

\section{Bloktoets (enige preliminaire gegevens).}

In de toetg van de blakken 1.5 en 3.2 zijn enkelle vragen opgenomen ower de tinhoud van het onderwerp warop de computersimulatieprograma's betrekking hadden. In blok 1.5 (atherosclerose) zijn twee van deze ttems in de formatleve toets opgenomen. In tabellen 10.5 en 10.6 is een overzicht gegeven van de resultaten van 10 studenten (experimentele groep) op items ' 130 ' en '131' in het studiejaar 1980/1981 naar rangorde van de totale score van de studenten bij deze bloktoets. Het totaal aantal items was ongeveer 1150 stuks.

In tabel. 10.5 is te zien dat 8 van de 10 studenten uit de experimentele groep behoren tot de 25 beste studenten van de 100 van deze toets. De score m.b.t. 1tem 131 (tabel 10.5) blijkt voor de experimentele groep duidelijk beter dan de score van de overigen. Bij item 130 is At minder duidelijk het geval. Worden van beide items tesamen de score bekeken dan blifkt er een duldelijk verschll te bestan tussen de experimentele groep en de overigen. De score "allebeil de items goed" is laag (30\% resp. 12\%), maar de score "geen een ltem goed" laat zlen dat de experimentele groep beter scoort dan de over 1 gen (10\% resp. $58 \%$ ). Als deze percentages worden vergeleken en ultgezet in een frequentieverdeling zoals in flguur 10.1 is gedaan, dan blijkt dat er tussen de experimentele groep en de overlgen een significant verschil bestaat. De experimentele groep heeft een gemiddelde score van 1.2 "goed" $(s d=0.6)$ en de overigen een gemiddelde score van 0.54 "goed" ( $s d=0.7)$. 
Tabel 10.5 Score op item 130 en 131 in studiejaar 1980/81

\begin{tabular}{|c|c|c|c|c|c|c|c|}
\hline $\begin{array}{l}\text { Rangorde } v . d . \text {. } \\
\text { student op } \\
\text { bloktoets }\end{array}$ & ite & $\begin{array}{l}130 \\
\text { fout: }\end{array}$ & ?: & $\begin{array}{l}\text { ite } \\
\text { goed: }\end{array}$ & $\begin{array}{l}131 \\
\text { but : }\end{array}$ & $?$ & $\begin{array}{l}\text { Totaalscore v.d. } \\
\text { student op } \\
\text { bloktoets: }\end{array}$ \\
\hline 2 & 1 & 0 & 0 & 1. & 0 & 0 & $79 \%$ \\
\hline 9 & 0 & 1 & 0 & 1 & 0 & 0 & $65 \%$ \\
\hline 10 & 1 & 0 & 0 & $\perp$ & 0 & 0 & $64 \%$ \\
\hline 11 & 1 & 0 & 0 & 1 & 0 & 0 & $63 \%$ \\
\hline 14 & 0 & 1 & 0 & $\mathbb{1}$ & 0 & 0 & $62 \%$ \\
\hline 15 & 0 & 0 & 1 & $\mathbb{1}$ & 0 & 0 & $61 \%$ \\
\hline 22 & 1 & 0 & 0 & 0 & 0 & I. & $56 \%$ \\
\hline 25 & 0 & 1 & 0 & 1 & 0 & 0 & $55 \%$ \\
\hline 57 & 0 & $a$ & 1 & 1 & 0 & 0 & $44 \%$ \\
\hline 70 & 0 & 0 & 1. & 0 & 0 & 1 & $38 \%$ \\
\hline $\begin{array}{l}\text { Total experi- } \\
\text { mentele groep: }\end{array}$ & $40 \%$ & $30 \%$ & $30 \%$ & $80 \%$ & $0 \%$ & $20 \%$ & $-\quad(n=10)$ \\
\hline $\begin{array}{l}\text { Totaal } \\
\text { overigen: }\end{array}$ & $20 \%$ & $22 \%$ & $58 \%$ & $37 \%$ & $5 \%$ & $58 \%$ & $--\quad(n=90)$ \\
\hline
\end{tabular}

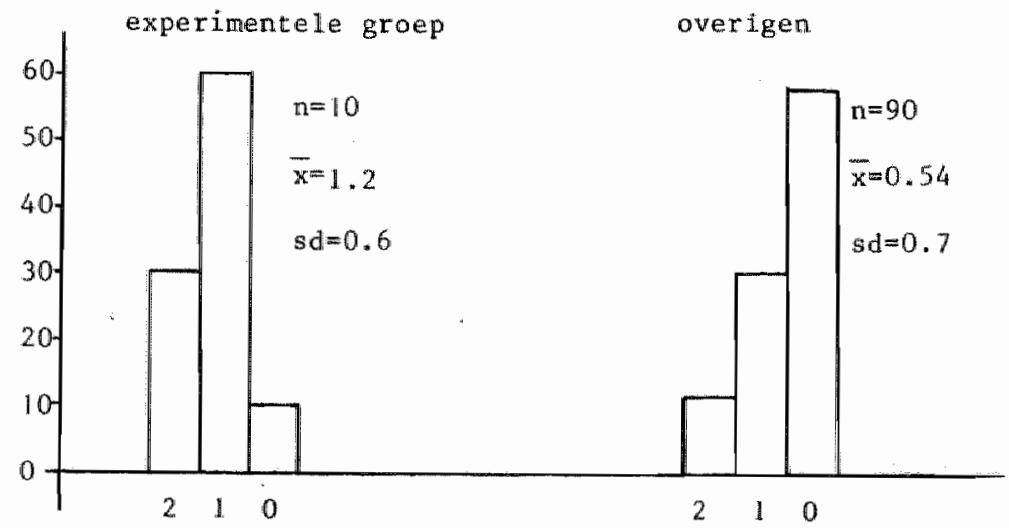

figur 10.1. Score op item $130 \mathrm{en} 31$ tesamen in studiejaar 1980/81. Er is een slgniflcant verschil tussen de experimentele groep en de overigen $(t=2.81 ; \mathrm{p}<0.01)$. 
Tabel 10.6 score op item 130 en 131 tesamen in studiejaar $1980 / 81$

\begin{tabular}{|c|c|c|c|c|}
\hline & $\begin{array}{l}\text { alles goed } \\
\text { (2) }\end{array}$ & $\begin{array}{l}\text { een goed } \\
\text { (1) }\end{array}$ & $\begin{array}{l}\text { geen goed } \\
\text { (0) }\end{array}$ & totaal \\
\hline Experimentele groep: & $3(30 \%)$ & $6(60 \%)$ & $1110 \%$ & $10(100 \%)$ \\
\hline Controle groep: & $11(12 \%)$ & $27(30 \%)$ & $52(58 \%)$ & $90(1002)$ \\
\hline
\end{tabular}

In blok 3.2 (moeheld) in het studiejaar $1981 / 82 \mathrm{zijn} 5$ items m.b.t. de stof die in het computersimulatieprograma CARDIO aan de orde kont, opgenomen. De resultaten zijn te zien in tabel 10.7 .

Tabel 10.7a Score op ale bloktoets items tesamen in studiejaar $1981 / 82^{2}$ )

$\begin{array}{lllll}\text { experimentele groep }(\mathrm{n}=10) & 52 \% & \text { goed } & \mathrm{sd}=12 \% & 1) \\ \text { controle groep }(\mathrm{n}=58) & 53 \% & \text { goed } & \mathrm{sd}=13 \% & \end{array}$

1) geen significant verschil tussen belde graepen

2) gezien het grote aancal vragen hebben 5 wragen een te verwarlozen invloed op de totale score.

Tabel 10.7b Score op 5 items tesamen in studiejaar 1981/82

$\begin{array}{llllll}\text { experimentele groep }(n=10) & 88 \% & \text { goed } & s d=19 \% & 1) \\ \text { controle groep }(n=58) & 67 \% & \text { goed } & s d=32 \% & \end{array}$

1) significant verschil tussen beide groepen $(t=1.99, p<0.05)$

2) zie noot 2 tabel $10.7 \mathrm{a}$.

Allereerst is gekeken (in tabel 10.7a) of de experimentele groep signiflart hoger scoort in de gehele toets. Dat blifkt niet zo te zijn. De experimentele groep en de controle groep zijn dus vergelijkbaar. In tabel 10.7b blijkt ut de gegevens vam de twee groepen dat de experimentele groep hoger scoort ( $88 \%)$ dan de controlle groep (67\%). Er blijkt een aantoonbar verschil te bestaan tussen de experimentele groep en de controle groep $(t=1.99 ; p<0.05)$. De studenten die het computersimulat Leprograma CARDIO gedaan hebben in dit blok over moeheid scoorden signiftcant beter op de betreffende items.

Vogrtgangstoets (enige preliminaire_gegevens)

De expertmentele groep wan 10 studenten die in de formatieve toets van het onderwijsblok 1.5 (studiejaar 1980/81) zijn vergeleken met een controle groep (zie tabellen 10.5 en 10.6) zijn op een 
Lets andere wijze ook vergeleken ill vier voortgangstoetsen. In een voortgangstoets die vier maal per jaar door alle studenten wordt afgelegd, wordt gekeken naar de gemiddelde groei in algemene kennis (zie hoofdstuk 1.3). Door de manier van data verwerking is het moge$11 j \mathrm{k}$ om de groepen te vergelijken in de gemiddelde groei in kennis op een geselecteerd terrein. Er is gekozen voor het toetsen van de resultaten op items die betrekking hebben op het hart en vaatstelsel. (één van de 13 categorieën uit de voortgangstoets, cf.hoofdstuk 1.3).

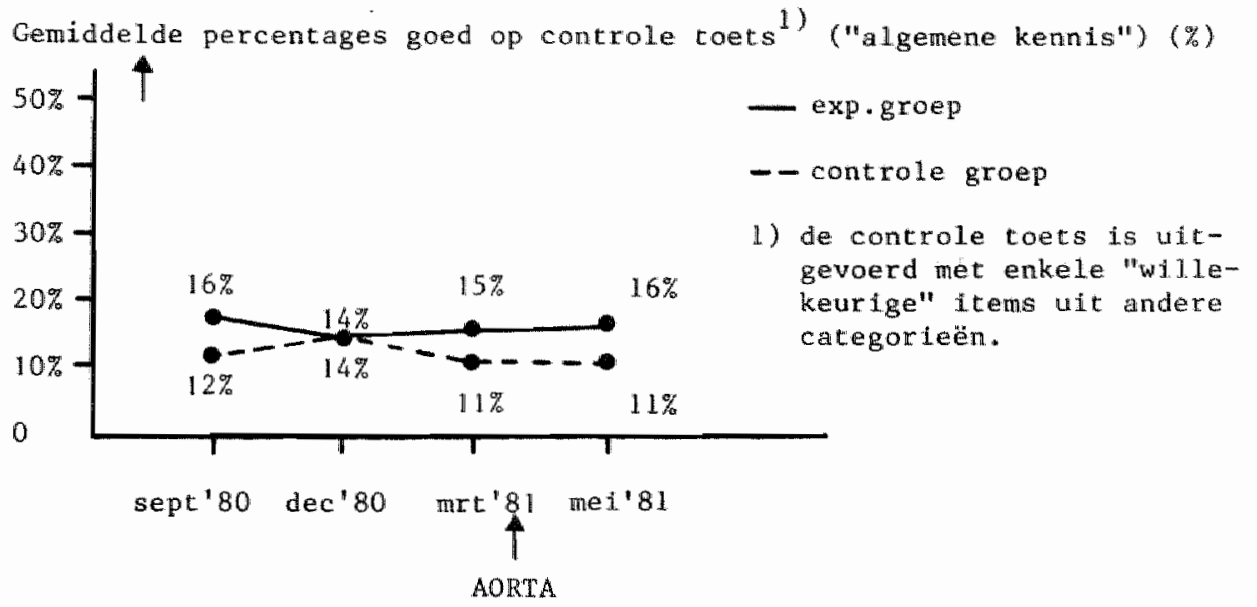

figuur 10.2. Algemene kennis verloop. (Het programma AORTA werd gepresenteerd op het moment aangegeven met een pij1.)

Gemiddelde percentages goed op experimentele toets (hart- en vaatstelsel)(\%)

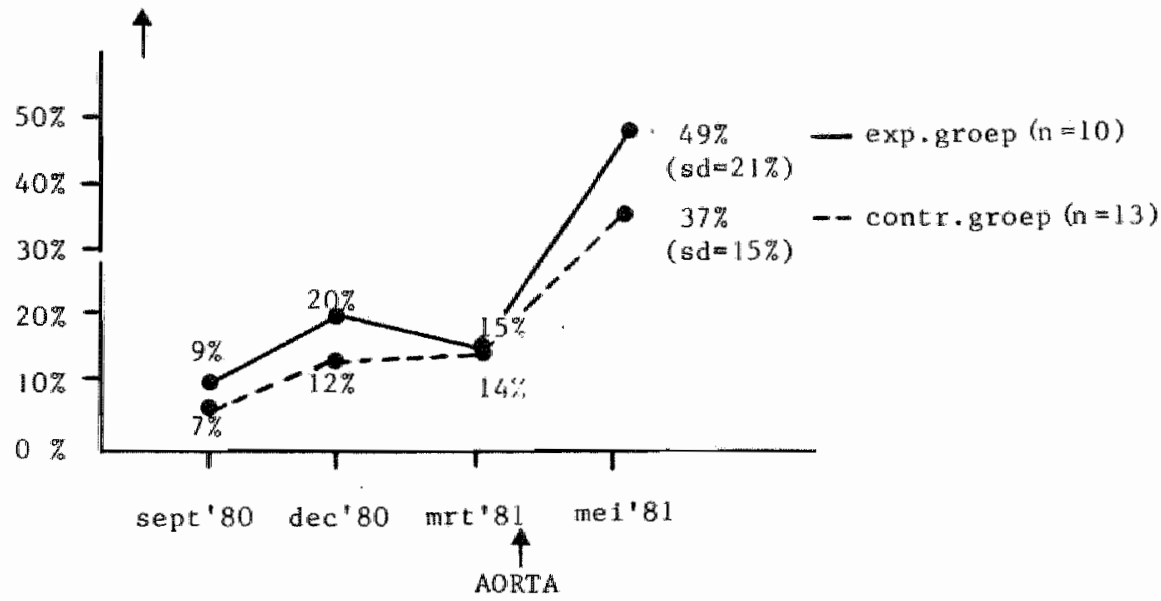

figuur 10.3. Specifieke kennis verloop. (verschil in me1.81: $t=1.53,0.05<p<0.10)$. 
De percentages $21 j n$ relatef laag ondat de voortgang m.b.t. het einddoel na zes jaar gemeten wordt wardoor er geen aprake is van "leerstor-gebonden" toetsen.

De resultaten toonden aan dat ten eerste er geen sigmificant verschil in percentages goede antwoorden in "algemene kennis" kon worden vastgesteld tussen belde groepen in de resultaten wan de voortgangstoets van september 1980, december 1980, mate 1981 en mei 1981 (figuur 10.2). Ten tweede dat er geen significante verschillen waren tussen beide groepen $4 n$ gemiddelde kennis m.b.t. het hart en vaatstelsel in de voortgangstoetsen (f1guur 10.3) van december 1980 en maart 1981 . Maar tenslotte bleek dat er in de voortgangstoets van mei 1981 , net na de perlode dat de experimentele groep had gewerkt met het computersimulatieprogramma AORTA, een verschil was in het percentage goede antwoorden van de experimentele groep t.o.w. de controle groep wat betreft de kennis over hart en vatstelse1 (score $49 \%$ met $s d=21 \%$ resp. $37 \%$ met $\mathrm{sd}=15 \%)(\mathrm{t}=1.53 ; \mathrm{df}=21 ; 0.05<\mathrm{p}<0.10)$. Het verschil is echter niet signiflcant volgens gebruikelijke normen.

De hier gepresenteerde gegevens zijn slechts preliminair. De ontwikkeling van adequate meetinstrumenten voor de toetsing van het kennisniveau van medische studenten gedurende hun opleiding aan de Rijksuniversiteit Limburg bevindt zich pas in een pril stadium. Nadrukkelijk worden hier dan ook geen vergaande conclusies getrokken omtrent de invloed van computersimulat les op het concrete kennisniveau van de studenten. Anderzljds lijken de data van voldoende belang voor een eerste presentatie in dit kader. Toekomstig onderzoek zal uitvoeriger moeten antonen in welke mate computersimulatieprogramals inzicht beworderend werken in het medisch curriculum. 


\subsection{Conclusies}

Het computersimulatieproject is in 1978 an de Rijksuniversteit Limburg gestart met een oriëterende fase gedurende welke een keuze werd gemaakt voor de hardware, de software en de opzet voor het RL-computer simulatiesys teen.

De opzet die gekozen is biedt, gezien de resultaten met het prototype en met 5 operationele en diverse nog niet in her onderwijs beproefde programa's, de mogelijkheid nieuwe modellen te antwikkelen met het RL-computersimulatiesysteem tot volwaardige CAI-computersimulatieprogramma's voor het medisch onderwijs.

De 5 operationele computersimulatieprograma"s zijn stuk voor stuk in het onderwijs beproefd. De resultaten $z i j n$ in de hoofdstukken $3 \mathrm{t} / \mathrm{m} 9$ uitgebreid bediscussieerd.

Inmiddels hebben circa 400 studenten gemiddeld 2 contacturen per sessie doorgebracht aan de computer. Veel gebruikt zijn de programma's AORTA ( $t / m$ studiejaar $1981 / 82$ ruim 300 contacturen), CARDIO (ruim 100 uren) en MACDOPE (ruim 300 uren). Dit is begrijpelijk daar deze programma"s al wat langer beschikbaar zijn dan de overige. Wit de evaluatie van de gegevens blijkt dat per blok 10-70\% van de studenten van een aangeboden programma gebruik makkt.

Met dit computersimulatiesysteem zijn diverse andere modellen ontwikkeld en meer of minder uitgetest welke nog niet in het onderwljs $z$ ijn opgenomen, omdat deze modelien pas onlangs gereed zijn gekomen. Dit geldt voor de computersimulat leprogramma's ENZYM en FARMA. Er zijn nog enkele computersimulatieprograma's die hier niet zijn besproken geimplementeerd in het RL-computersimulatiesysteem:

- AXON, een computersimulatieprogramina met een rodel van de Hodghim en Hunxley vergelifking voor de electrische aktiviteit over de membraan van een exciteerbare cel;

- GUYTON (versies CIRCE en FKPG), een computersimulatieprogtama met een model van de blaeddruk regulatie volgens Guyton et al.;

- IMMUNo, een computersimulatieprograma (in een testiase) m.b.t. de dynamica van immunologische processen;

- MYOCARD, een computersimulatieprograma m.b.t. de linker ventrikel dynamica;

- HUMAN, een computersimulatieprograma met een zeer ultgebreid model van een aantal regelmechanismen in de mens wolgens ldeeern van Coleman et al. Dit model (met 2000 vergelijkingen) functioneert nog 
niet valledig onder het Rl-computersimulatiesysteem.

Met de ontwikkeling wan al deze programults onder een en hetzelfde systeem is angegeven dat er op een breed terrein mogelijkheden zijn voor computersimulatieprograma"s. Ook is hiermee angegeven dat medewerkers van unfversiteiten op vakgebleden war wiskundige modelvorming. mogelijk lijkt te zijn, -dat kan dus ook buiten de medische wetenschappen zijn-wan dit systeem gebrulk kunnen maken om de ontwikkeling van een dergelijk computersimulatieprograma ter hand te nemen. of ook alle programma"s geschikt blijken te zijn voor het onderwijs dat zal steeds moeten blijken.

Tenslotte nog enkele aanzetten voor ontwikkelingen die het RL-computersimulatiesystem zal kunnen ondergaan:

- de presentatie van grafische output op een ander grafisch weergavesysteem met bijbehorende hardcopy mogelijkheid dan dat van het huidige prototype. Te denken is aan het GIGI-systeem;

- bij de grotere modellen zal. het inspecteren van de warden van modelparameters op een selectlevere manler dan nu het geval is moeten gebeuren. Te denken valt aan enkele categorieën zoals patiëntgegevens (gewicht, temperatuur), laboratoriumgegevens (urine, bloedbeeld) en geneesmiddelenoverzicht e.d.;

- het lijkt van belang ook onderzoeken te doen met dit leermiddel in andere onderwijssystemen om een meer algemeen inzicht te krijgen in de invloed die een bepaalde opzet van het onderwijs heeft op het leren door studenten;

- het is van belang woor toekomstig onderzoek de invloed van dit leermiddel op het leren door studenten systematischer na te gaan. Binnen het onderwifssysteem an de RL zal hiertoe in the bloktoetsen en de vortgangstoetsen een uitgebreider systeem van evaluatie moeten worden ontwikkeld.

Af $s$ lutitend kan samengevat worden dat de thans beschlkbare programma"s bestudering van problemen coestaan die op een andere wijze heel moeilijk te benaderen zijn. Deze problemen zijn direct gekoppeld aan de inhoud van het onderwijsblok waratan de studenten in de betreffende periode werken. Op deze wife worden de computersimulatieprograma's leermiddelen nast alle andere die ter beschikking staan. Dit voorkomt een al te geisoleerde plaats van de computer in het onderwijs, een euvel. waram al veel experimenteren van Computer Assisted Instruction geleden hebben. 
N.B. Informatie, listings en/of source van/over de hier genoemde pragrama's en van het RL-computersimulatiesysteem (RLCS-systeem) is/zijn te verkrijgen bij de auteur via het adres van de capaciteitsgroep farmacologie, postbus 616, 6200 MD Maastricht. 
HOOFDSTUK 11

Summary and conclusive remarks

The use of computers in eduction has experienced an explosive development during the last years. Thete is still much research going on as to the choice of computer configurations, proper software adequate learning programs etc. One of the approaches to the application of computers in education is the use of one of the strongest features of the computer, viz its power to perform simulations of complex systems. This thesis describes a study on the development of a computer simulation system for the stmulation of biological processes to be used in a problem oriented medical curriculum.

In chapter 1 the most important domains of this study are introduced: (a) the role of the computer as an educational appliance. More specifically the developments of "Computer Assisted Instruction" (CAI) are briefly introduced; (b) simulation is introduced as a method in education. The possiblities of computersimulations on the basis of mathematical models are discussed from the point of view that this approach allows the study of fundamental concepts underlying complex biological systems; (c) the specific educational environment at the University of limburg $(\mathbb{R L})$ is introduced. The specific features of the problem-oriented medical curriculum are discussed.

The first part of chapter 2 discusses methods of mathematical modeling and simulation of biological systems. In the second paragraph of this chapter arguments are discussed that led to the realisation of the RL-computer simulation system. Speciflcally the choice of programing language, terminal system, computer configuration, machine-student adaptations, response-times and ergonomy is argued. The last part of this chapter describes the RL-computer simulation system to be used In later chapters in combination with different mathematical models. The hardware of the system is discussed as well as the software, the individual modules and files of the system.

Chapter 3 describes the results of implementing a mathematical model on basic hemodynamics into the RL computer simulation system. This program -AORTA- allows students the study of basic hemodynamic relations between pressure, wolume, flow, reststance and compliance. The model is based on a "windkessel" model of the aorta. It allows stmulation of the 
effects of hemodynamic disturbances on the pressure and flow in the major arterles.

Chapter 4 presents the results of CARDIO, simulation program on blood pressure regulatton under normal and abnormal conditions. The model winderlying this progran is a more advanced model of cardiovascular control than that used in AORTA. It allows the simulation of pathological conditions, such as myocardial lafarct, renal artery stenosis or renal insufficlency. On the other hand therapeutic interventions in abnormal conditions can also be simulated. The program allows the application of drugs like cardiac glycosides, diurecics or vasodilators.

Chapter 5 describes the computer simulation program Fuldos. The mathematical. model underlying this program contalns over 200 variables and describes control mechanisms of body flutd volumes and electrolytes as well as respiratory control mechanisms. This models allows a variety of simulations of e.g. thirst, fluid loss, exaggerated drinking, carbon dioxide inhalation, severe physical exercise etc. Again, students can also intervene therapeutically in an abnormal steady-state of the model by infusing flutds of different composition, giving a diuretic etc. The basic physiology of resplracory and metabolic acidosis and alkalosis can be studied with this model.

Chapter 6 contains a description of a two-compartment model underlying the computer simulation program FARMA. This program allows students to become conversant with basic pharmacokinet tc principles such as the half-life, clearance of distribution volume of a drug.

In chapter 7 the mure detalled pharmacokinetic program MACDOPE, which was originaly developed at McMaster University in Hamilcon, Canada, is discussed. This program is analyzed with respect to the structure of the mode1, thus allowing implementation into the RL computer simulation system. Moreover, a number of experiments on the pharmacom kinetic behaviour of acetylsalficylic acid and ampicillin in different patients are presented.

Chapter 8 discusses the computer simulation program ANAMNESE. In contrast to all other programs ANAMNSE ls not based upon a mathematical model. 
Rather, it simulates the anamnestic interview between a doctor and a patient. This program contains a large data file with patient characteristics. The student can take the medical history of a selected patient only by systematically going through the relevant questions. Two examples of different patients are discussed in this chapter.

Chapter 9 discusses the computer simulation program ENZM. This program simulates the basic Michaelis-Menten kinetics of an enzyme reaction.

In chapter 10 the use of the different computer simulation programs of the previous chapters in the medical curriculum is discussed. The use of the different programs in the various years is presented. Furthermore the "behaviour" of students in compucer simulation sessions is discussed, specially in relation to the changes they make in the models. Next, some preliminary results are discussed on the appreciation of the programs by the students, as well as the influence of some of the programs on thetr level of insight in respective problems related to the simulations. It is concluded that there is a clear place for computer simulations as an educational tool in the medical curriculum. The frequency of use as well as the appreciation by the students shows the value of this tool. The general RL computer simulation system is a versatile program, allowing the introduction of a wide variety of mathematical models and simulations in a curriculum. 
A P P E N D I E $\mathrm{E}$

$---\cdots$ 
Appendix 2.1

Voorbeeld van de toepassing van het begrip "gain" bij biologische

systemen.

Het begrip "gain" bij biologische modellen kan omschreven worden als het vermogen van een systeem om een bepalde systeemvariabele zo goed mogelljk "te regelen" als er zich aan de "ingang" van een systeem een verstoring voordoet.

Een systeem met een "hoge gain" is beter in staat om variabelen constant te houden bij een plotselinge werandering dan een systeem met een "lage gatin"

Hier $z$ al aan de hand van een voorbeeld van Coleman (1977) een definitie worden afgeletd warmee in de praktijk van de biologische regelmechanismen door verschillende auteurs steeds wordt gewerkt (cf. Coleman, 1977a). Het voorbeeld zal in twee stappen worden opgebouwd. De gemiddelde arterlële druk (AP), die normal $100 \mathrm{~mm} H$ is, is het produkt wan het hartminuutvolume $(\mathrm{CO})$, dat normaal $5000 \mathrm{ml} / \mathrm{min}$ is en de totale perifere weerstand (TPR), die normal $0.02 \mathrm{mmHg} \cdot \mathrm{min} / \mathrm{ml}$ is.

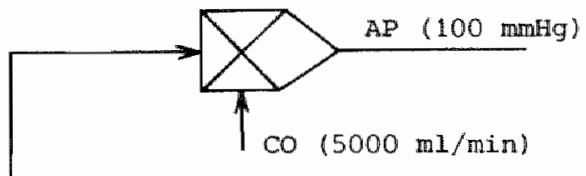

TPR $(0.02 \mathrm{mmHg} \cdot \mathrm{min} / \mathrm{ml})$

Tegelifkertijd kan door een eenwoudig experiment worden vastgesteld dat bif een proefpersoon die plotseling van een liggende naar een zittende houding wordt overgebracht een hartminuutvolume daling wan stel $1000 \mathrm{ml} / \mathrm{mln}$ tot $4000 \mathrm{ml} / \mathrm{min} \mathrm{kan}$ worden wargenomen. Dit impliceert, als we utgan wan een onveranderde totale perifere weerstand en de hlerboven besproken relatie, dat de gemiddelde arterlële bloeddruk net $20 \mathrm{mmHg}$ tot $80 \mathrm{mmHg}$ gedald zou moeten zijn. Door de plotselinge positieveramdering treedt er echter een reflexmatige compensatie in werklng die de totale perifere weerstand verhoogt. De relatie tussen de daling van AP en de verhoging van TPR kan experimenteel worden bepaald. Stel dat deze relatie in algebraische termen de volgende relatie is:

$$
\mathrm{TPR}=0.06-0.004 * \mathrm{AP}
$$

dan wordt het komplete regelsysteem, woor wat hier is besproken, als volgt vastgelegd in het volgende schema: 


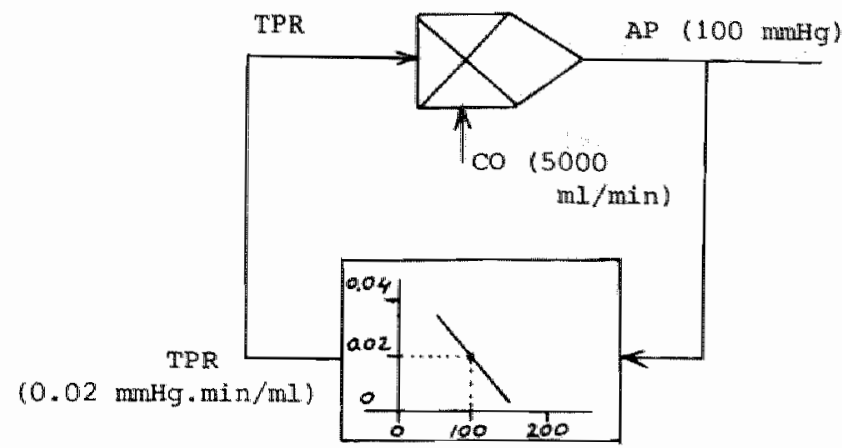

Dit systeem averziende kumen we ons woorstellen dat als om een of andere reden het hartminutvolume (CO) plotseling afneemt tot 4000 $\mathrm{ml} / \mathrm{min}$ dit omiddelijk door de arterlële bloeddruk wordt "gedetecteerd" en een verhoging van de totale perifere weerstand "initieert" waardoor er slechts een netto effect van in dit voorbeeld 7.7 mrahg bloeddruk daling optreedt.

Uitgaande van de hier gememoreerde bevindingen kan er een defintile worden opgesteld van de "galin":

gain $=\frac{\text { de "ongeregelde verstoring"-de"geregelde verstoring" }}{\text { de "geregelde verstoring" }}=\frac{20-7.7(\mathrm{mmHg})}{7.7(\mathrm{mmHg})}$ De "gafn" van dit reflexmechanisme wordt dan 1.6. De uitdrukking "gain" zoals die hier bij een biologisch madel indirect is afgeleid is identiek aan het concept van de open lus versterking bij een conventioneel lineair regelnetwerk. Merk echter op dat bij het hier besproken voorbeeld de "gain" tijdsonafhankelijk is. Vergeleken met: de beschouwingen over $\mathrm{G}$ en $\mathrm{H}$ in paragraaf 2.1 (en figuur 2.1) komt $\mathrm{d} i \mathrm{t}$ neer op een overdrachtsfunctie $\operatorname{van} G=1.6 \mathrm{en} H=1: \mathrm{d} \cdot \mathrm{w} \cdot \mathrm{z}$. er is geen integratie in de overdrachtsfunctile $G$ van de voorwardse weg. Er is hiler dan ook sprake van wat in paragraaf 2 . 1 een algebratsche loop wordt genoemd of ook wel een type o systeem, nl.:

$$
A P=f(A P)
$$

af te wel

$$
\mathrm{AP}=\mathrm{CO} *[0.06-0.004 * \mathrm{AP}]
$$

Over het algemeen is de overdrachtsfunctie 6 echter bij de hier beschreven modellen een "integrerend netwerk" met de overdrachtsfuncte $f(\varepsilon) d t$ die een functie van de tijd is en er als volgt kan uftzien (zie ook figuur 2.1):

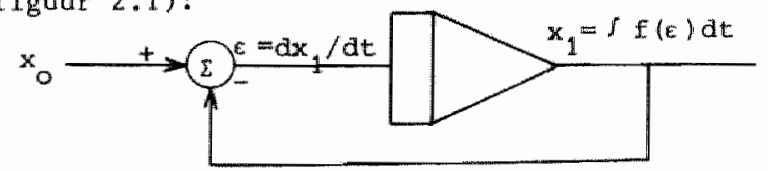


Merbif kunnen twee illustratieve opmerkingen worden gemakt die op een fundamenteel verschil wijzen met het eerste genoemde voorbeeld van de bloeddruk met aen thdsonafhankelijke galn:

1. Als $x_{1}=0$ en $x_{0}$ plotsellng toeneemt wan 0 tot 10 dan $15 \varepsilon=10(\varepsilon=$ maximal $)$, $d x_{1} / d t=10$ en $x_{1} z a l$ stijgen.

De $G$ is dan per definitie zeex klein

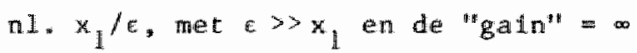

2. Als $x_{1}=x_{0}$ op $t=\infty$ en er dus eren stabiele coestand berelkt is zal $G$ per definitie zeer groot $21 j \mathrm{n}$ : n1. $x_{1} / \varepsilon$, met $c=0$ en de "gain" $=0$

Samengevat kan gesteld worden dat bij een teruggekoppeld integrerend systeem de "gain" een functle is van de tijd. 
Casus behorende bij het computersimulatieprograma AORTA

MORTA

Biathen:

Diercun:

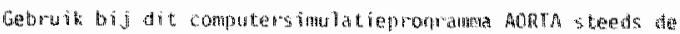

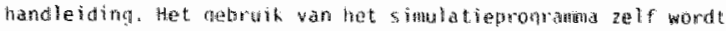

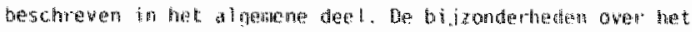

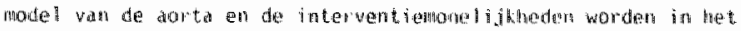
latste dee wat de landiciding hoschmen.

Tack 1. Het arota modell.

We ke fysische arootheden spolen bij dit motel volnens II een belangrijke rol? Noen en enkelle:

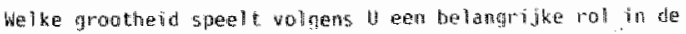
relatie tussen aruk en volume in de aorta? De nroothetd:

hellke graotheid speclt wolnens U een beldngrijke rol inde relatie tussen de druk in de acrta en de perifere stroom? De grootheid:

Taak 2 De normale blaeddruk in de aon ta.

Start an het computersimwlatieprograma AORTA en sirmaleer de

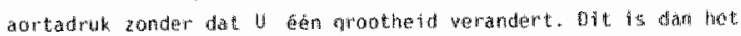

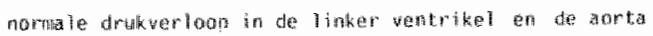

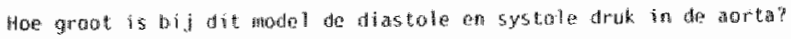
De diatiolische druk in da dorta fis:

libe syetolische druk in de forta is:

Enkele opmerkingen bij deze casus:

- De student heeft $z$ ich van tevoren op de hoogte gesteld van de begrippen compliantie, perifere weerstand en de bijbehorende eenheden.

- In het desbetreffende blokboek worden 3 pagina's aan dit programma en deze casus besteed. 


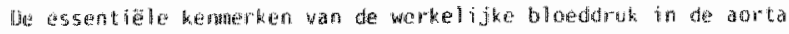

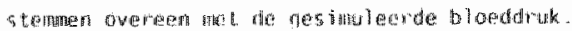

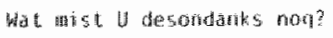

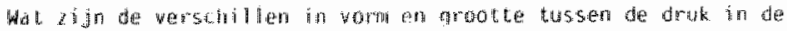
abrta en te linker ventrikel?

Taak 3. Veranderen van de compliantip

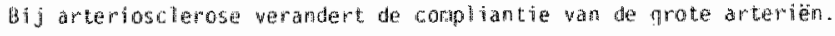
De vernindering yan de compliantie van de aomta kan worden gesinuleerd

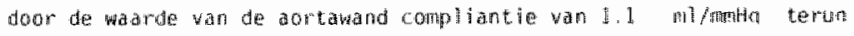

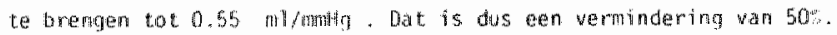
Doe dat eerrs.

Wat is het verschill van de druk in de aorta nu mete die lin de voriog simulatie?.

kunt ul iets meer zegren over hoe dat $k$ an qubeuren:

Wenkt U dat deze werschillen dianostische betekenis kunmen hetben woor het herkennen val sen arteriosclerosis?

\section{Tab. 4. Veranderen van de perifere weerstand}

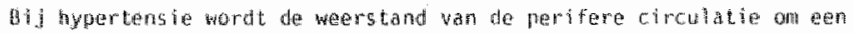
of andere neden verhoond. De verhoming wan de totale perifere weers tand

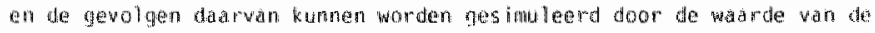

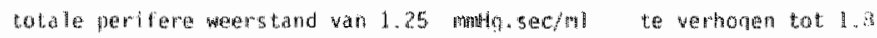

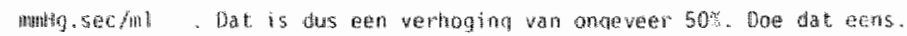

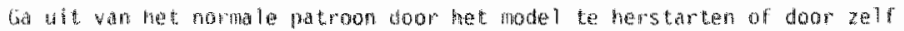

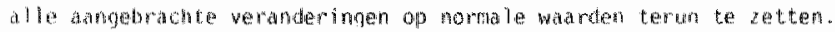


Wat is het verschil van de druh in de acma nu met die in de normalle situatide?

Wat is het versingl tussen de perifere stroom mu metie in de nomtale situatie?

Tauk 5. Veranderen man de maximale linker mentrikel druk

Het licham zal trachten de perifere stroom zo goad mogel ijk te handhaver op de homble warden. Dit model doet dat riet autanktisch. Indien u nog tijd over hebt kamt t, witgáande van de situaties zod is die bij tak 3 em 4 ajon ontstan eens proberen

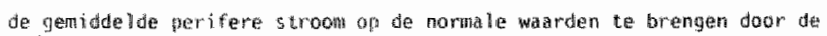
maximale linker ventrikel druk te weranderen.

Moet de maximale linken ventrikel druk dadrvoor vertoogdi of verlaagd worden?

Denkt $U$ dat de verschillen in systalische en diastolische druk in de aorta bij deze beide similaties diagnostische betekenis kunnen hebben voor het herkemnen vam
1. arteriosiclerosis tak 3 ja/ nee
taik 4 ja / nee
2. hypertensie tak 3 jo / nee
thak 4 ja / new

Wean suces. 


\section{Appendix 4.}

Analoge notatiew jze van het model

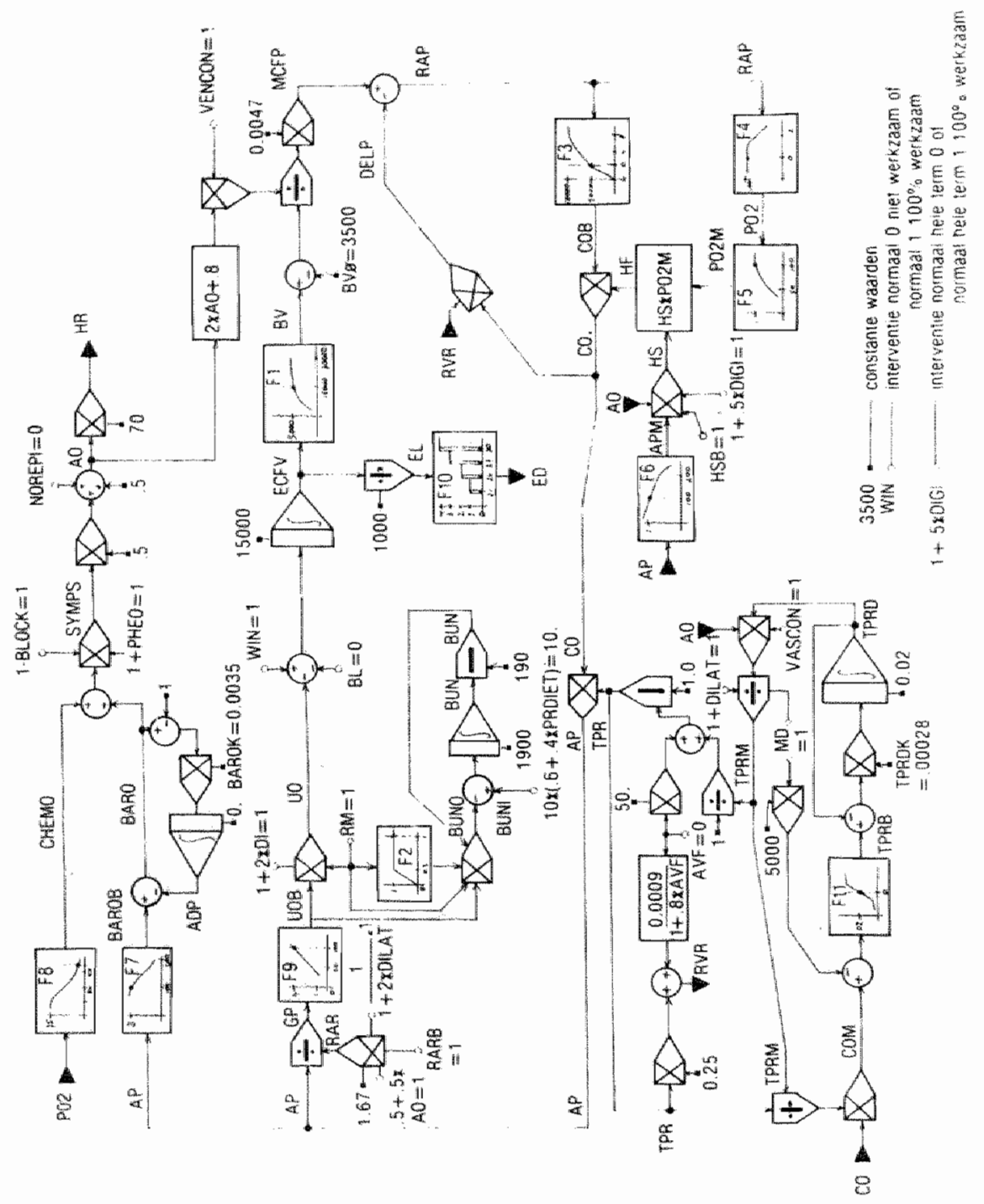


Append $1 \times 4.2$

Interventies (normal werkzaam)

Interventies die normaal werkzaam zijn (norms I), maar verhoogd of verlaagd kunnen worden.

* Basale renale arteriêle weerstand

$(\mathrm{RARB}=1 \ldots 0)$

groter dan 1.0 iriteriate nierstenase

* Renale massa

$(\mathrm{RM}=1.0)$

kininer dan 1.0 (acute) mier-

insufficientienefrectomie

* Proteine inname

$($ PRDIET $=\mathbb{1}, 0)$

kLeiner dan 1.0 ondemoedingrproteine tekort

* Water inname (ml/min)

$(W I N=1.0)$

kLeiner dan 1.0 withoging

moter dan 1.0 overvloedig drinken

* Selectieve veneuze constrictie

(UENCON $=1.0)$

indien groter dan 1.0

* Basale hartsterkte

$(\mathrm{HSB}=1.0)$

keiner dan 1.0 ticht hartinfaret

veel kieiner dan 1.0 wwar hartinfaret

* Selectleve arteriële constrictie

$($ VASCON $=1,0)$

(werkt niet op de niler)

indien groter dam 1.0 arieniele constrictie

indien kleiner dan 1.0 arteriele ditantie

* Metabole eisen

$(\mathrm{Mb}=1.0)$

yourer daw 1.0 inspanning 
Appeind fix 4.3

Interventes (normal niet werkzaam)

Interventies die normal niet werkaam zijn (normo): verstoringen en geneesmiddelen. Bi 1 de geneesmiddelen kan gebrulk gemaakt worden van dosis werkingsrelaties.

Verstoringen:

* Arterio-veneus fisted.

(AWF)

groter don 0 . directe verbinding tusenen arteräen en venert

* Feochromocytoom

groter dan o. verhoogle plasma catechotamines

* Bloedverlies

(BL)

protem dan o. bloedingen

Geneesmiddelen:

* Hartglycoside/digitalls

gnoter dan 0 . verhoging contractiekracht van de hartspier

* Vaatverwijcler (inclusief renale arteriën)

(DTLAT)

groter dan 0 . valuerwijaing

* Diureticum

groter dan o. tubulus funotie wordt gendizad

* Sympatricolytucum

groter dan o. ver laging sympatisehe acturitet

* Norepinephrine/noradrenaline

(NOREPI)

groter dan o. algehete vasoongtritute 


\section{Casus hypertensie}

Casus 2.

\section{Holeridig}

Hoge bloeddruk kom: bjj 10-15: van de volwassen bewouking woor. andat hypertemsie tot de risicafactoren woov camiavasulare monbiditeit en mortaliteit behoort, woet het behandeld worden.

Het ziektebeeld hypertensie noet diagnostisch aangenomen warden indiem bij herhaaldelijk blueddruk meten op verschillende tijden de druk bowen de grens wan $160 / 95$ intitg ligt. De nomale bloeddruk gate tot 140 , 90 mithan daartussen spreekt wen van borderline-hypertensie.

Dorzaken var hoge bloeddruk zijn verschillend (zia tabel). Van primaire (essentiele) hypertensie spreekt men als geen oorzalk kan worden aangewezen. dit kont bij ongeveer 90 van de gevallen woor. De ziektebeeldem bij secundare hypertensie spreken woor zich.

Tabe 1: Gorzaken en women van hypertensie.

1. Primaire (essemtiële) hypertensie.

1. Secundaitre hypertenste:

1. Renaali: a) parenchymateus (b.w. chron.glomerulanefritis. pyelonefritis

b) wasculair (b.w. mierarteriestenose)

2. Endocrien (b.w. Conn syndroon, feochromoncytoom)

3. Carretatio aortian

4. Gemengde vorm (b.w. zwangerschapstoxicose, intracranièle tumory.

N.B. In dit computersimitatiepmograma wordt de bloddruk al leen a is genrddelde arteriele bloeddruk (AB) angegeven. De systolischol diastolische boeddruk is hieruit vita de onderstande formule te berekenefl:

$$
A P=p \text { diastole Psystole }- \text { Potiastolla }
$$

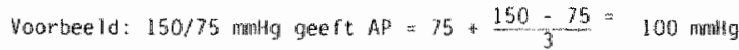




\section{Vervolg 4.4}

\section{Cat 10}

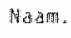

Oistimit.

\section{Casus 2.}

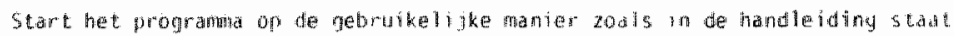

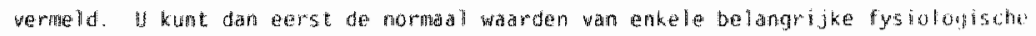

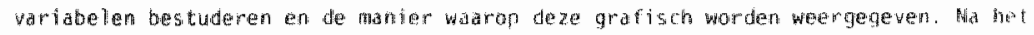

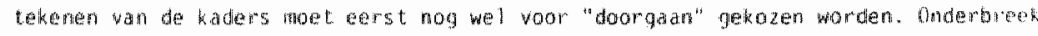

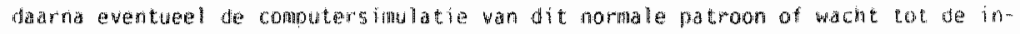
gestelde tijd var 15 dagen is werlopen. kies nu voor de mogelijkheid een tasus te bestuderen. Et 21 jn 6 casussen, he bespreken hiep casus?.

Nadat U casus ? dadorkelijk uitgekozen heeft en de bloeddruk over 2 dagen

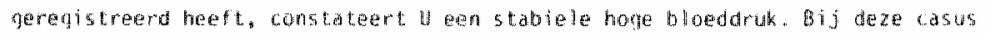
gati het nis niet 20 yeer on de vorm of de oorzak. I constateent dus hoge bloed-

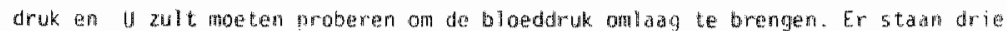
verschillende mogel jkheden to jull ie beschikking.

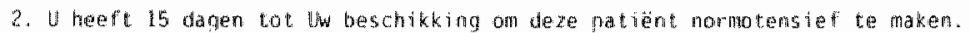

Opdracht l: Suchrije een watwembijder woor.

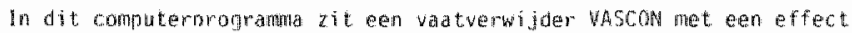
zoals in de handleiding is a angequeven.

Hoevee

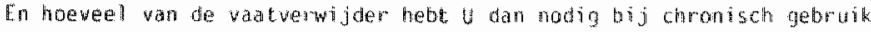
on on $A P=100$ te komen?

$\ldots \ldots \ldots \ldots \ldots \ldots$ (bed jo de fos iswerkirgacurvel.

Prober nu ears de vagen te beantuoonden;

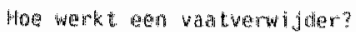

war werkt en valuamider op in?.

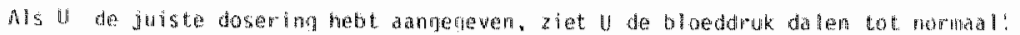

Ki 
opdracht 2: Als tweede keuze hebt $U$ een diureticura, kies aen dos is mb, w. de dosiswerkingscurve. lad dit een par dagen werken en stop de simulatie op het scherm.

Probeer te beantwoorden:

Hoe werkt een filureticum?.

Ziet $u$ effecten bij de urineproduktie?

Wel ke bi jwerkinger moet U vorkomem?

Wat zal gebeuren als de therapie gestopt wartut? hoer net uit.

Opdracht 3: De derde mogel ijkheid bestat uit het geveri wan een symathoticolyticum. kies een dosis m. b.v. de dosiswerkingscurve en bekijk wat er gebeurt. Hoe werke een sympathicalyticim?

Welke effecten heeft hij?

Welke bijwerkingen zijn te werwanten? 


\section{Casus zwaar hartinfarct}

CAOPRO

MAMAS.

DATUR.

\section{CASUS 3}

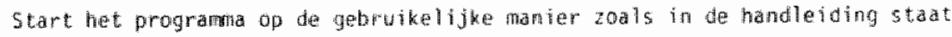

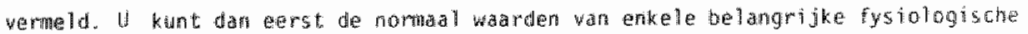
warlabelen bestuderen er de manter warop deze grafisch worden weergegeven. Ha het tekenen van de kaders moet eerst nog wel voor "doorgab" gekozen worden.

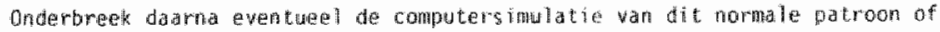
wach tot de ingestelate hija vam 15 dagen is verlopen. Kies nu voon de mogelijktheid een casus te bestuderen. Er zijn 6 casussen. He bespreken hier casus 3. Nadat U weuze gedan heeft simuleert het programala cen bepald pathologisch beeld. Als u op het grafische schem kjokt ziet U de variabelen verancierew. Hierma stopt de computer de ingeprongrabeterde shuatie.

De volgende situatie heert zicin afgespeld: Als husarts mordt ll door de wrouw wan een pationt opgebeld dat I zeer snel langs moet komen. Har man woelde zich opeens duizellig, ging op bed highen en werd bawsteloos. U ver noedt iets ergs en wijdt mat hum huis. U ziet eer man, die bewusteloos is, op bed liggen.

Als u de grafieb bekijkt 2 ult U het volgende makkelijk kumnen beantwoorden:

1) Wat is veranderd?

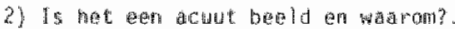

3) Hat heeft dere man? 
Verwolg 3 .

De oorzak en de werklaring woor de veranderingen is: deze mall heeft thuis een zwar hartinfarct coorgenakt.

oparacht 1 : Wat gat gebeuren als U geen therapie toepast? Probeem het wit en kijk of $u$ de pathofysiologische veranderingen kint? verklarer (kies opniew deze casus 3). . . . . . . . . . . . . . .

Opdracht 2 : 5 probeert hem te helpen met een hautglycoside. schrijf hem digttalis (0lGI $=0.8)$ wor en ga verwolgers Uw therapie cantraleren.

wat zal gebeureri? ................

Wat zal gebeuren als U DIG it hogere dosering voorschrijft, b.v. 1.2? Probeer date ens (door the corrigeren vanaf de laatstue onderbrekingl..... .

opdracht 3 : Kies nog eens casus 3 en probeer een therapie met een valutwerwijder. Schrijf hem een watweraijder (VASCON) voor.

We lke effecten heeft de watverwijder hier?...

Is ditu wenselijk in deze situatie? Hoe zal het beeld op langere termijm uitzien?. .

Opdracht 4: Start mon eens opnieuw met deze patient (casus 3) en

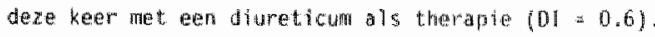
Warrom wordt een diuneticum toegediend ha een hartw infarct?

Opdracht 5 : Probeer als u nog tijd ower hebt bij deze casus 3 erar combinatie van de? genecsilld delen te gever b. digitalis

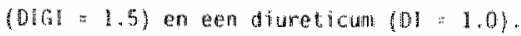




\section{Cans licht hartintarct}

CARMO

MAAH.

DATUA.

\section{CASUS 4}

start het programida op de gebruikelike manier zojls in de handleiding stat: wermeld. U kunt dan eerst de norna 1 warden wan enkele belangrigke fyshon gische wariabelen begtajeren en de marier warop deze grafisch worden weergegeven. Wa het tekenen wan de $k$ aders mot cerst nog wel woor "doorgata" gekozen worder. Onderbreek daarna evertueel de computersinulatie van dit normalle patroon of wacht tot de ingestalde tijo van 15 dagen is vertopen.

Kies nu voor de mogelijkheid een catus te bestuderen. Er zijn 6 casusser. We bespmeken hier casus 4. Nadat y th keuze gedan heeft simuleert het prom

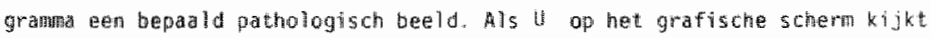
ziet u de variabelen varanderen. Harma stopt de computer de ingeprogrameerde situatile.

De vilgende situatie heeft zhch afgespeeld: Als huisarts worth $U$ door de wrouk van een patient opgebeld dat $U$ snel langs moet komen. Haar nan voelde zich opeens hiet goed en ging op bed Higgen. $U$ vermoedt iets ergs en rijdt natar hum huis. U ziet een man, bleek geztcht op bed liggen. Hij ver. telt: "Ik voelde mij opeens zo duizeligen ik heb zo'n angst".

Als $U$ de grafiek bekijkt zult t het wolgende makkelijk kunnen begratwoorden:

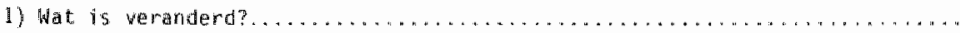

2) op de graflek is te zien dat de gentidelde arterible druk (Ab), de cardiac

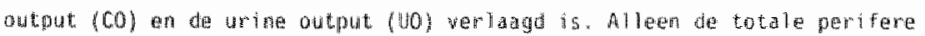

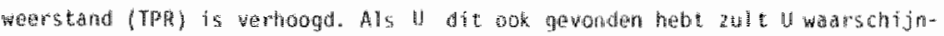

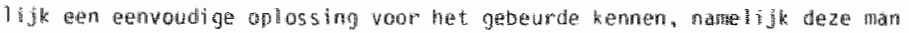

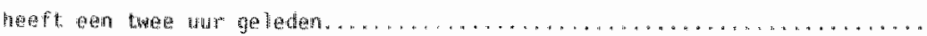

3) Kurt U de afwijkingen worklaren?" 
vervolg 4

De oorzazk en de verklaring voor de verameringen is: deze man heeft thuis een licht harthofarct doorgenath $t$.

Opdracht 1: Wat zou gebeurd zijn als I geen therapie zou hebben toregepast?

Probeer het uit en kijk of $U$ de pathofysiologische veranderinglen kunt verklaren. Kies opmieum deze cals Lis 4.

Opdracht 2: U probert hen te helpen met een hartglycoside. Schrijf them digitalis (DIGI $=0.4$ ) voor em ga vervolgens Uw therapie contrateren.

Wat zal er gebeuren?

Wat zal ar gebeuren als U Digl in een hogere dosering vorschijft b.w. 0.8? Probeer tat weens foor the corrigeren vanaf de latstio onderbreking)...........

Wat wourkont 4 met digltalis op langere termijn? . ..

opdracht 3 : Kies nog eens casus 4 en probeer eens een therapic met een vadwerwijder. Schrijf hem eem valverwijder (VASCON) voor. Helike effecten heeft de vatverwijder? . . . .......

,

Is dit wenselijk in deze situatie?

Hoe zal het beeld er op langere teming witzien?.....

Opdracht 4 : Start nog eens opnieuw het deze patient (casus 4 ) en deze keer met een diureticum ats therapie (01 $=0.4$ ).

Warom word een diureticum toegediend ma cen hartinfarcts. .

helle organ probeert y dartoor te sparen?

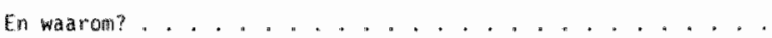

opdracht is: Probeer als nog tiju over hebt bij deze casus een combinatie wan deze gerbesmiddelen te geven b.v. digitalis (DLG $=0.4)$ en een diureticum $(0)=0.4 j$. 
H解a

Da toun

Casus 5.

Start het programa op de gebrukelijke manier zods in de handleiding

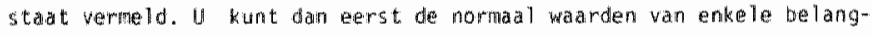
$r$ ije fyshologische variabelen bestuderen en de manier waarop deze grafisch wordert weergegewen. Na het tekenen wan de kaders moet eerst nag wel woor "doorgaan" gekozen worden. Onderbuek daarna, indien gewenst, de computersinulatie wan dit nomale patroon of wach tot de ingestelde thijd wall 15 dagen is werlopen. Kies nu wor de magei i jikheid een casus te bes tudieren.

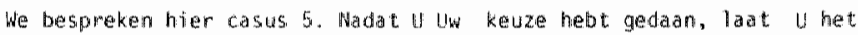
pragranmin tot dag 2 normal lopen. De computer sthopt bij dag 2 van zelf. u kum nu acute mierinsurficientie sinulerem, die b.k. kan optreden na een trabua (met zwar bloedverlies shock). Hertoe wordt de functionele renale massa (=RM) plotselinal werminderd. Probeer eerst deze wagen te beantwoordem alworens $\mathrm{U}$ werder gat.

Wat denkt U gat gebrewren net de to

mat de Ap

met te bo

met de $H R$

met de TPR

met de $3 y$

net de GP 
Vervolg 4.7

Vervollgi 5 .

CARDIO

Naxtrat

Do tนun

Verander dian nu in het thodel de parameter RM. Maak RM : 0.3

Toets mu uw bevindingen van hicer voor door de simulatie een paar dagen te taten lopen.

Beschiniff de hemodynamische gewolgen wan dit acuut beeld:

Wat denkt $U$ dat er zou gebeuren als U niets zou doem in de eerste 2 dagent na de ingreep?

Wat is het grote gevaar bij dit beeld?

Hoe kunt U dit voorkonen?

Wat doet in dit geval on de situatie te veranderen, eventuele therapte?

Wat zal gebeuren als $U$ ook nog de wateringame (HIN) beperkt, b.V.

(WIH) = O)? 


\section{Source van het model}

C

C MODEL: T.G. COLEMAN, UNIVERSTTY OF MISSISSIPPI, USA.

C BEWERKT: F.B.M. MIN, H. VAN KAN, H.A.J. STRUYKER BOUDIER.

C

$\mathrm{C}$

REAL, LIE, LIC, L.E, LXC, L BE, L 3C, MCFP, MD, NOREPI

COMMON MODEL/ RAR, GP, UOB, UO, BUNO, BUNI, QBUN, BUN, T, DI

+ ,RARB, DILAT, EM , DI, PRDIET, OBUND, Tด, ERR, REQ1, REQ2

+ ,ECFV, EL, ED, BV, MCFP, REQ3, REQ4, REQ5, REQ6, REQ7

+ ,WIN, BL, ECFVO, VENCON, BV9, TLOOP, TLAG, TUUR, D39, D49

+ ,HS, HF, POZM, COB, CO, PO2, RAP, DELP, AP, APM

+ ,DIGI, ESSB,D53,D54,L1E,L1C,L2E, L 2C, L 3E, L3C

+ , RVR, TPR, TPRM, TPRB , TPRD, DELCO, COM, TMAX, DT, DTG

+ , VASCON, DIAS, TPR $\varnothing$, TPRDK, MD, AVF, TMI, TMA, D79, D8 $\varnothing$

+ ,CHEMO, BAROB, ADP, BARO, SMMPS, AO, HR, D88, D89, D99

C

+ ,PHEO,BLOCK, NOREPI, BAROK, ADPQ, D96, D9 7, D98, D99, DUM

$\mathrm{T}=\mathrm{T}+\mathrm{DPT}$

TUUR $=\mathrm{T} / 6 \emptyset$.

TDAG=TUUR/24.

$D Y D T=W I N-C O-B L$

$\mathrm{ECFV}=\mathrm{ECFV}+\mathrm{DYDT} * \mathrm{DT}$

IE (ECFV.LE. Ø. Ø) $\mathrm{ERR}=-1$.

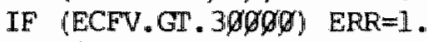

IF (ERR. NE. O.) GOTO $7 \varnothing$

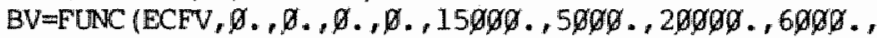

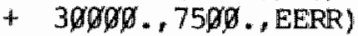

BUNI $=1 g *(.6+.4 *$ PRDIET $)$

IF (RM.LT. $\varnothing.) \quad E R R=-2$.

IF (RM.GT.1ด.) $\quad \mathrm{ERR}=2$.

IF (ERR.NE. O.) GOTO 79

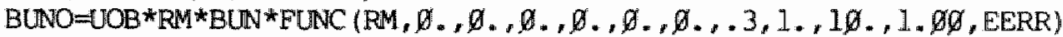

$D Y D T=B U N I-B U N O$

QBUN $=$ QBUN $+D Y D T * D T$

$B U N=O B U N / 19 \varnothing$.

DYDI =TPRB *TPRDK-TPRD *TPRDK

$T P R D=T P R D+D Y D T * D T$

DYDT $=B A R O K *(B A R O-1 . \varnothing)$

$A D P=A D P+D Y D I^{*} * D T$

$\mathrm{C}$

C BEGIN LOOP I

C

$\mathrm{IID} \quad \mathrm{N} \perp=\mathrm{N} \perp+1$

IE (N1. GT. 100) ERR=1ळ.

IF" (ERR.NE. Q.) GOTO 79

TPRM $=$ AO *VASCON *TPRD $/(1$ ( $10+$ DILAT $) *(M D))$

TPR=1. $D / 150 . \star \mathrm{AVF}+1.0 / \mathrm{TPRM})$

$\mathrm{RVR}=.0009 /(1.04+.8 * \mathrm{AVF})+.025 * \mathrm{TPR}$

C

$M C F P=.9047 *(B V-B V Q /(V E N C O N *(.2 * A O+.8)))$ 


\section{BEGIN LOOP 2}

C

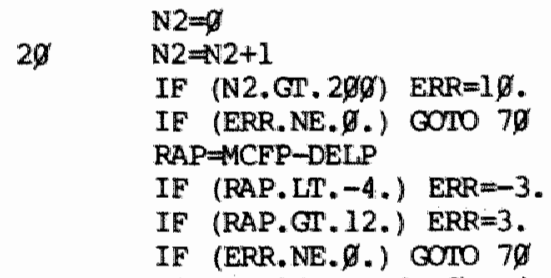

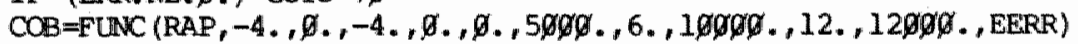
$\mathrm{PO} 2=\mathrm{FUNC}(\mathrm{RAP}, 0 ., 190 ., 10,100 ., 0 ., 100 ., 5 ., 100,20 ., 0 ., \mathrm{EERR})$

IF (PO2.GE. 4\%. .AND. PO2. LT.8ด. .AND. REQ1.NE.-1.) REQ1=1.

IF (PO2.GE. 35. .AND. PO2.LT. 4ø. .AND.REQ2.NE.-2.) REQ2=2.

IF (PO2.GE. 39..AND. PO2.LT. 35. .AND. REQ3.NE. -3.) REQ3=3.

IE (PO2. LT. 3ø. . AND. REQ4.NE. -4 .) $R E Q 4=4$.

C

C. BEGTN LOOP 3

C

$30 \quad \mathrm{~N} 3=\varnothing$

$\mathrm{N} 3=\mathrm{N} 3+1$

IF (N3.GT. 1 $\varnothing \varnothing) \quad E R R=1 \emptyset$.

IF (ERR.NE. $\varnothing$.$) GOTO 7 \varnothing$

IF (PO2.LT. Ø.) $\quad \mathrm{ERR}=-4$.

IF (PO2.GT. 2øळ.) ERR=4 .

IE (ERR.NE. $\varnothing$.$) GOTO 7 \varnothing$

PO2M=FUNC (PO2, $\varnothing ., \varnothing ., 5 \varnothing ., .5,65 ., 85,9 \emptyset ., 1 . \emptyset, 2 \varnothing \emptyset \ldots, 1 . \emptyset$, EERR)

$\mathrm{HF}=\mathrm{HS}$ * $\mathrm{PO} 2 \mathrm{M}$

$\mathrm{CO}=\mathrm{HF} * \mathrm{COB}$

$A P=C O N T P R$

IF (AP. LT. 85. .AND. REQ5.NE. -5.) REQ5=5.

IF (AP. IT. Ø.) ERR $=-5$.

IF (AP.GT. 25\%.) ERR=5.

IF (ERR.NE. $\varnothing$.$) GOIO 7 \varnothing$

$\mathrm{APM}=\mathrm{FUNC}(\mathrm{AP}, \emptyset ., 1.3, \emptyset \ldots, 1.3, \emptyset \ldots, 1.3,2 \varnothing \varnothing, \ldots .7,259 ., 0 ., \mathrm{EERR})$

$\mathrm{HSC}=\mathrm{APM} * \mathrm{HSB} * \mathrm{AO} *(1 . \not+.5 * \mathrm{DIGI})$

IF (ABS ( (ESC-HS)/HS) . LE. L3E) GOTO $4 \not$

$\mathrm{HS}=(1.8-\mathrm{L} 3 \mathrm{C}) * \mathrm{HS}+\mathrm{L} 3 \mathrm{3C} * \mathrm{HSC}$

$\mathrm{C}$

GOTO 396

C CONTINUE WITH LOOP 2

$\mathrm{C}$

49

DELPC $=C O * R V R$

IF (ABS (DELPC-DELP) . LE. L2E) GOIO 50

DELP $=(1 ., \not-L 2 C) *$ DELP $+L 2 C *$ DELPC

$\mathrm{C}$ GorO $2 \varnothing$

C CONTINUE WITH LOOP 1

C

50 CONTINUE

IF (AP.LT. 5ø.) $\mathrm{ERR}=-6$.

IF (AP.GT, 150.) ERR $=6$.

IF (ERR.NE. $\varnothing$. .) GOTO $7 \%$

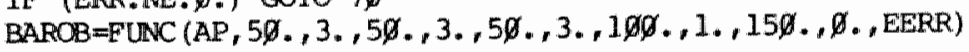

$B A R O=B A R O B-A D P$

IF (PO2. LT. Ø.) $\quad \mathrm{ERR}=-7$. 
IF (FO2.GT. 296\%.) ERR $=7$.

IF (ERR. NE. $\left.\varphi_{.1}\right)$ GOTO 79

CHEAO $=F U K C(P O 2,6 \ldots, 75,30 ., 75,69 ., 75,99 ., 9 ., 299 ., 9 .$, EERR $)$

$S M P S=($ EAPO +CHEMO $) *(1 . \varnothing-$ BLOCK $) *(1 . \varnothing+$ PHEO $)$

$\triangle O C=.5 * S M M P S+.5+N O R E P I$

IE (ABS ( (AOC-AO) /AO) . LE.LIE) GOTO $6 \varnothing$

$A O=(1.9-L I C) * A O H L I C * A O C$

C GOTO 198

C END OF LOOP

$\mathrm{C}$

69

CONIINUE

$\mathrm{RAR}=1.67 *(.5+.5 * \mathrm{AO}) * \mathrm{RARB} /(1.9+2 . * \mathrm{DILAT})$

$G \mathrm{G}=\mathrm{AP} / \mathrm{RAR}$

IF (GP. LII. 30.) ERR=-8.

IF (GP.GI. 90.) $\mathrm{ERR}=8$.

IF (ERR.NE.,. ) GOTO $7 \varnothing$

$\mathrm{UOB}=\mathrm{FUNC}(\mathrm{GP}, 3 \not \varnothing ., 9 ., 45 ., 2,60 ., 1 ., 8 \varnothing ., 4 ., 9 \varnothing ., 5 ., \mathrm{EERR})$

$\mathrm{OO}=\mathrm{UOB}^{*} \mathrm{RH} *(1, \not+2 . * \mathrm{DI})$

$\mathrm{EL}=\mathrm{ECFV} / \mathrm{L}$.

$\mathrm{ED}=0$.

IF (EL.GI.21..AND.EL.LE*24.) ED=1.

IF (EL.GT.24 . AND. EL. LE. 27.) ED=2.

IF (EL.GT. 27. .AND.EL. LE. 30.) ED=3.

IF (EL. GT. $3 \not$.$) ED=4.$

IF (ED. GE. 1. . AND. REQ6. NE. -6.) REQ6=6.

$\mathrm{COM}=\mathrm{CO} *(\mathrm{TPR} / \mathrm{TPRM})$

$D E L C O=C O M-5 \not Q Q \varnothing$. *MD

IF (DELCO. LT. -59090 .) ERR $=-9$.

IF (DELCO.GT. 5990\%.) ERR=9.

IF (ERR. NE. 1.$)$ GOTO $7 \varnothing$

$+$

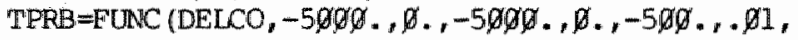

$\mathrm{C}$

$\mathrm{HR}=7 \not 2 * \mathrm{AO}$

$500, . .103,5000 ., .04$, EERR $)$

C TESTING FOR ERRORS AND MESSAGES

$\mathrm{C}$

76

CONTINUE

IF (ERR. EQ. \%. D) GOTO BQ

IF (ERR, LT. D. D) NUMBER $=42 \not+2 *$ (INT (ARS (ERR)))

IF (ERR.GT. Ø. $\emptyset)$ NUMBER=450+2*(INI (ERR))

CALI LEES (NUMBER)

CALL LEES (419)

GOMO 199

810 IF (REQ7.EQ.2.) COTO 99

IF (REQ1.NE. \%. „OR. REQ2. NE. Ø. .OR.REQ3.NE. Ø. .OR. REQ4. NE. Ø. .OR.

+ REQ5.NE... .OR.REQ6.NE. (.) REQ7=1.

IF (REQ7.EQ. $\emptyset$.$) GOTO 19Ø$

CALL CURSID $(B, \varnothing)$

CALL ERASIO (Q)

CALL CURSIg $(8, \phi)$

$\mathrm{REO} 7=2$.

$90 \quad$ ITIM $=$ INI (T/6Ø.)

IF (REQ1. EQ. 1.) WRITE (LO, 1OQQ9) ITIM 


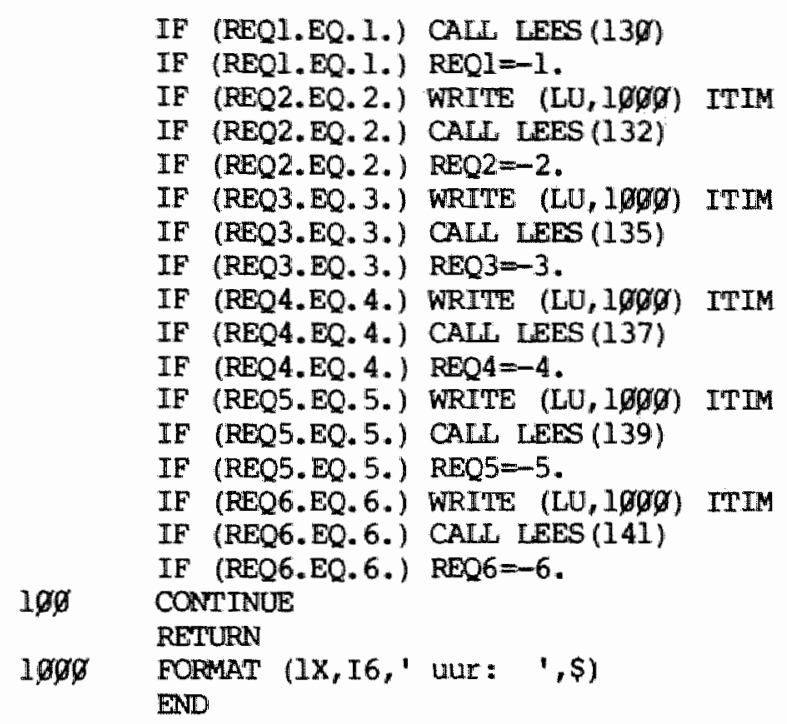


Appendix 5.1

Model van Ikeda (Ikeda et al.,1980)

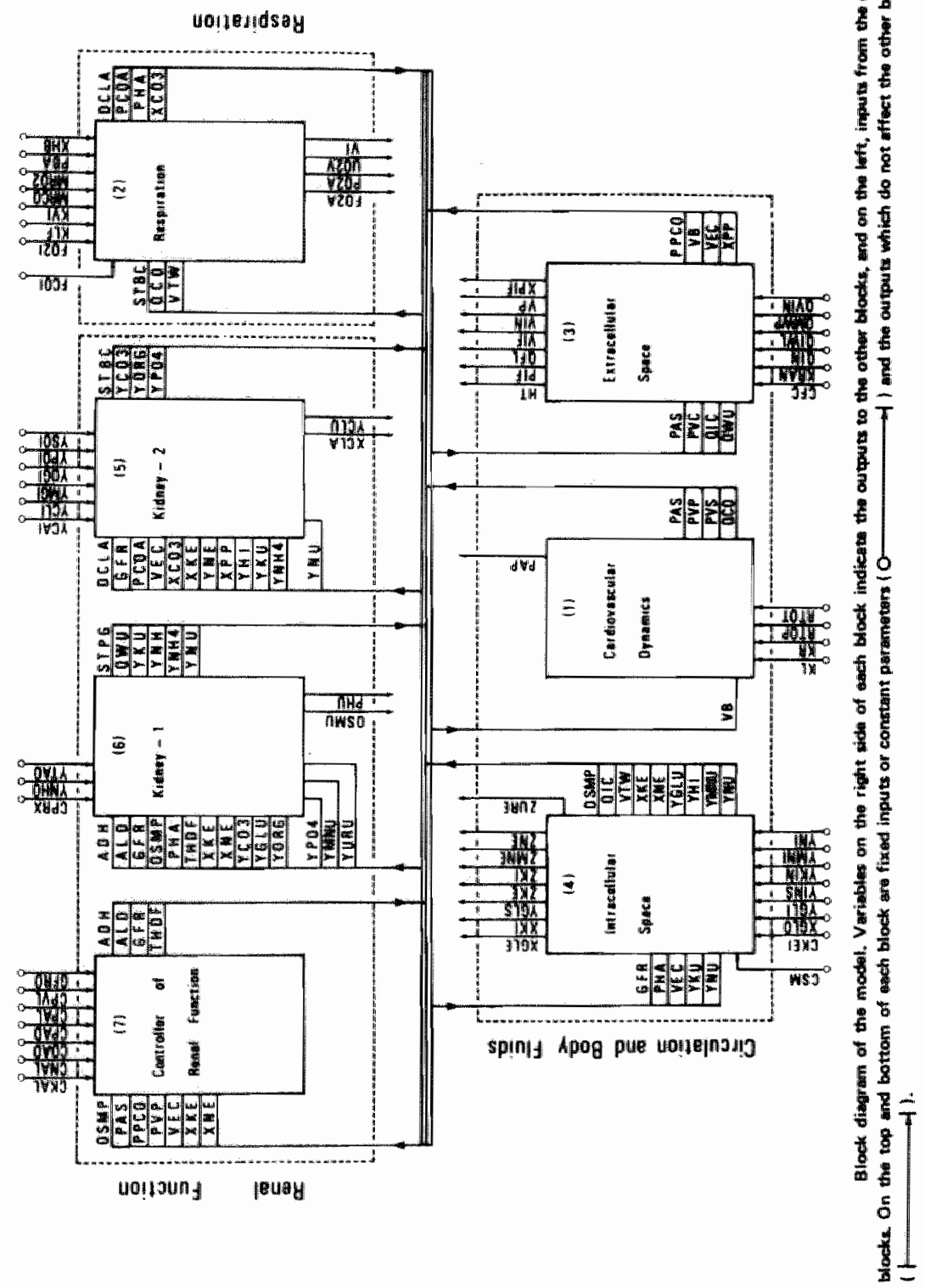


Append $1 \times 5.2$

Enkele interventies die met het computersimulatieprogramma FuUIDS gedaan kunnen worden.

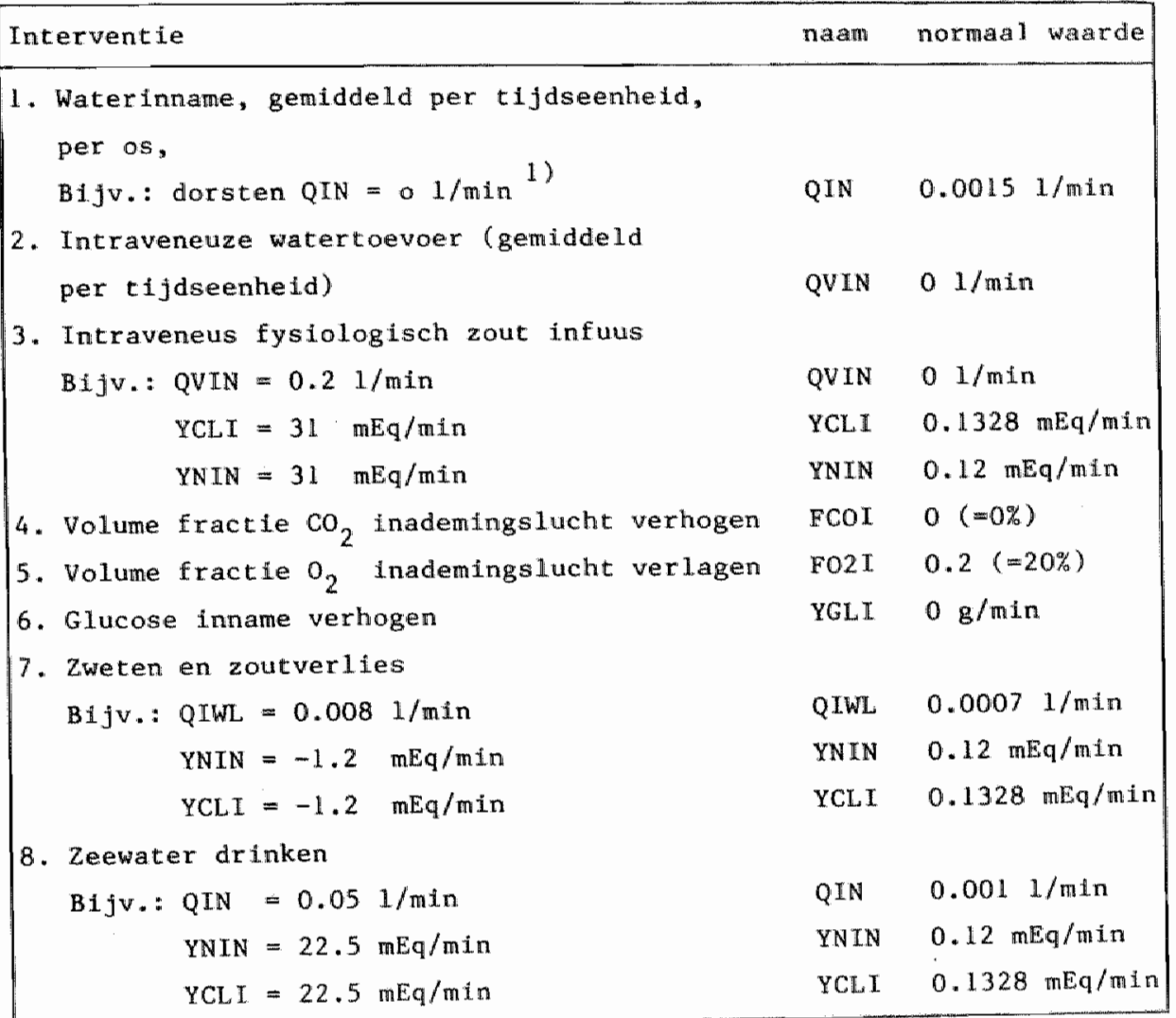

1) Het protocol bijl de eerste letter van de namgeulng in dit model is: Q duidt op flow in liter per minuut

Y duidt op hoeveelheid per minuut

$Z$ duidt op hoeveelheid

$\mathrm{X}$ duidt op concentratie

$\checkmark$ duidt op volume

$P$ duidt op druk 
Apperid 1x 5.3

Enkele belangrijke varabelen van het computersimulatieprograma FLLIDS met de normal warden in steady state bij een gezonde vrijwillger van 55 kllogram.

\section{Varlabelen:}

\begin{tabular}{|c|c|c|}
\hline VIC & Intracellulatir volume & 20 \\
\hline VEC & Extracellulatr volume & 11 \\
\hline VIF & Interstitleel volume & 8.8 \\
\hline VB & Bloedvolume & 4 \\
\hline VP & Plasmavolume & 2.2 \\
\hline
\end{tabular}

XNE Concentratie natriun in VEC

$140 \quad \mathrm{mEq} / 11$ ter

XCLE Concentratie chloor in VEC

$104 \mathrm{mEq} / 1 \mathrm{iter}$

XKE Concentratie kallum in VEC

$4.5 \mathrm{mEq} / 11$ ter

PHA pH van het arteriële bloed

OSMP Osmolalftelt in het bloedplasma

mosm/1iter

OSMU Osmolaliteit in de urine

PO2A O 2 druk in de alveoli

$\mathrm{mmHg}$

$\mathrm{PCOA} \mathrm{CO}_{2}$ in de alveoli.

munHg

PAS Gemiddelde arteriale bloeddruk

100

munth

QWU Urine output

$0.0015 \mathrm{ml} / \mathrm{min}$

HT Haematocriet

ADH Effect van het antidiuretisch hormoon 


\section{Appendix 5.4}

\section{Casus dorsten, zweten en zoutverlies}

Fivtas

Manen:

Datum:

\section{CASUS 5 en 6 (Dorsten)}

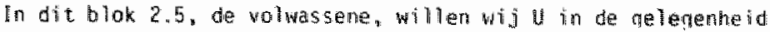
stellen am zelf eens in de water-en zouthuishowding van een volwassem praefpersoon in te grijpen.

If kent dat doem a an de hame wan enkele problemen die voorkomen in de casus "wadiopen" uit het blakboek.

Wit deze casus zullen we drie problemen lichten en deze trachten te sinulieren:

- dorsten nedurende 8 uua

- zweten gedurende of wur

- drimken van cen halve liter zerewater ergens onderwen

- en een combinatie van deze drie

Indlien u nog tijd oweq houd kunt $u$ eventueel bij deze proeforsonen de gevalgen wan een infurs met fysiologisch zout bestuderer.

Als aandachtspunten en tevens als Veendoelen, noemen we in het bijzonder:

- de mechanismen ter commensatie wan dehydratie

- de rol van aldosteron en het ADA onder deze onstandingeden

- de bloedgassen in deze situaties

- de bloeddruk in deze. situaties

- het plasmavolume

- het extracel lulaire volume

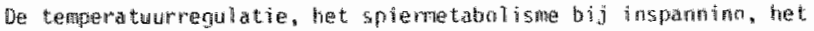

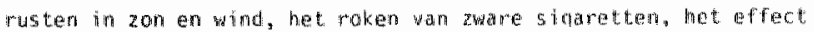

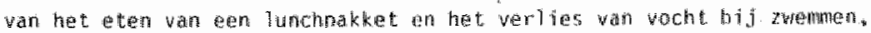
laten we hien butter beschouring.

\section{Faik 1. Worsten}

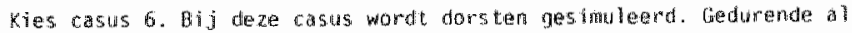
de uren war de simulatie krijgt deze proefpersoon niets to drinken. bij alle valgende taken blifit deze nersoon dorsten! 
Beantwoordt de vollgende 3 yragan voordat $U$ de simulatie uitwoert.

Wat gebeurt er met de blloedorwk (PAS)?

Wat gebeurt er met de osmolaliteit van de urine (OSMU)?

Wat gebeurt er met het antidiuretisch homoon (ADH)?

Wat gebeurt er net het aldosteron (ALD)?

Inspecteert $U$ eens na 8 uur de precieze warden wan deze wariabelen:

- de gemiddelde arterlecte bloeddruk was 100 en it mu: mitritin

- de osmolatiteit van de urine was 461 en is nu: mots $/ 1$

- het antiduretisch hormoon was 1 (- $100 \%$ ) en is nu

- her aldosteron was 1 (100w) en is nu

\section{Taak 2. Dorsten en zweten.}

In de normale situatie heeft deze proefpersoon een vochtverles door" zwetten van $0.00071 /$ initin. Bij inspanming in te hete zon wordt deze factor veel hoger. Dit kunt $U$ sinuleren door de factor alwh te veranderen tot $10.0081 / 1$ inn (dat is equivalent met 0.5 l/uur). Simuleer zoutverlies doar YNIN $=-1.16600$ en $Y C L I=-0.86$.

Kles wederom cosus 6 zodat tw proefnersom niet alleen miets drinkt maar bovendien veel wocht verliest door zweten. Beamtwoordt de volgende 3 vragen voordat I de sinulatie witwoert.

Wat gebeurt er met de bloeddruk (PAS)?

Wat gebeurt er met de osmolaliteit wan de urine (OSH)Y?

Wat gebeurt er met het antidiuretisch homoon (ADH)?

Wat gebeurt er met het aldosteron (AlLo)?

Inspecteert $U$ na $B$ uur eens de precieze warden vam deze variabelen:

- de geniddelde arteriele toeddruk was 100 en is mu: montha

- de osmolallteit van de urine was 461 er is nu: mosm/1

- het antidfuretisch hormoon was 1 ( $100 \%$ en is inu:

- het aldosteroni was 1 (100\%) ,en is mu

Iaak 3. Dorsten, ziweten en anderwen zeew ter drinken.

Doet $U$ beide stmullaties nu nog eens opnielw (dus tak 2). Stop vervalgens ergens onderweg de silnulatie en simuleer op die plats het drinken wan een halve liter zacwater.

Ons voorstel is dit drinken na te bootsen door de parameter alN gedurende 10 mimuten op 0.05 /min te zetten en dasma weer 0 te maken. Dýt kamt neer op het drinken van 0.51 . water. Darbij dient tegelijkertijd de 
matrium en chloor imame YNIN en YCLI 22.5 mEq/min te aijn over 10 minuten. Dat kamt neer op 225 mEq Natrium en 225 mEq chloor. Beantwoordt de 3 volgende vragen woordat u het drinken wan zeewater sinuleert.

Wat gebeurt er met de bloeddruk? (PAS):

Wat gebeurt er met de asmolaliteit van de urine? (OSAu)

Wat gebeurt er met het antidiuretisch harmoon? (ADw)

Wat gebeurt er met het aldosteron (AlO)?

Stel de looptij op 10 mot muten in. Breng de veranderingen an het model aan. Málik na 10 minuten de $G I N=0.0, Y C L I=-0.86$ en YNIM $=-1.2$, dus weer gelijk aan de uitgangswarden.

simulleer vervolgems tot het programma stopt na 3 us..

Inspecteert $U$ mu eens de precieze warden van enkele varinbelen:

- de gemiddelde arterielle bloeddruk was 100 en is mu

- de osmolaliteit van de urine was 461 en is nu....................mosm/l

- het amtidiuretisch hormoen was $1(=100 \%)$ en is nu

- het aldosteron was 1 (100\%) en is nu

- de kaliumconcentratie in het ECV was 4.5 en is nu

- de natriumconcentratie in het ECV was $140 \mathrm{en}$ is nu..................

- de chloomconcentratie in het ECV was 104 en is nu _..._............mEg/l

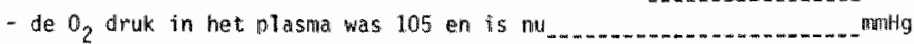

- de $\mathrm{CO}_{2}$ druk in het plasma was 40 en is nu

Als $U$ woldoende tijd heeft kunt $U$ taak $2 \mathrm{t} / \mathrm{m} 3$ ook eens doen uitgaande vain casus 5. Daarbij is het en ge verschi t.o.w. casus 6 dat er 6 andere wariabelen worden gemeten gen geregistreerd waronder: WP, PCOA, PO2A, WT, PHU, XWE ER XCLA.

Succes.

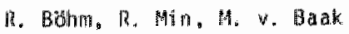


Append $1 \times 5.5$

Casus fysiologisch zoutinfuns

FU105

Namen.

Qalum

\section{Castos 1}

U kunt bij deze casus eer antal experimenten doen. als keuze kunt $U$

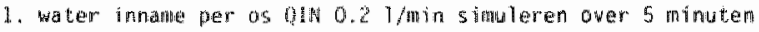

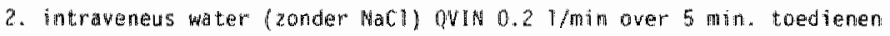

3. een fysiologische zoutoplossing intravereus over 5 min. simuleren

$\begin{array}{lll}\text { (ONIN }=0.2 \mathrm{l} / \mathrm{min} & & \text { (nom:0) } \\ \text { YCLI }=31 \mathrm{mEq} / \mathrm{min} & & \text { (nom:0.1328) } \\ \text { YNIN }=31 \mathrm{mEq} / \mathrm{min} & & \text { (nom:0.12) }\end{array}$

NE: Als U wanaf het begin ( $T=0$ ) begint dan stopt het programa automatisch na 5 minuken, anders niet.

Weel succes. 
Appendix 5.6

Source van het model

C

C MODEL: N. IKEDA, SCHOOL OF MEDICINE,

C KITASATO UNIVERSITY, JAPAN.

C BEWERKT: F.B.M. MIN, H. VAN KAN, H.A.J. STRUYKER BOUDIER.

C

C

REAL KR, KL, MRCO, MRO2, KVT, KLF

COMMON MODEL,T, PAS, PWS, PAP, PVP

1 ,RTOT, RTOP, KR, KL, PVPG, PVSD, , OCO

2 ,PCOA, PHA, XCO3, DCLA, VI, UCOV, UO2V, ECOA

2 ,FO2A, PO2A, MRCO,MRO2, FCOI, FO2I

2 ,PBA, XHB, KVI, KLF' UHBO, TRSP

3 ,VB, VEC , PPCO, XPP, HP, VP, VIF ,PIF, QLF

3 , OCFR, ZPP, ZPIF, ZPG, ZPLG, VIN, XPIE, CFC

3 ,CRAV, VRBC, QIN, QVIN, OMWP, QIWL, PC

4 ,D57, XNE, XKE, YHI, YGLU, YMNU, YURU, VTW, OSMP

4 , OIC, XGLE, YGLS, XKI, VIC, ZNE, ZKE, ZKI

4 ,ZHI, ZGLE, ZMNE, ZURE, YNIN, YKIN, YGLI

4 , YMNI, YURI, YINS, XGL $\%$, CSM, CKEI, CGLI

4, CGL 2, CGL 3, PHI, YTMT

5, YCO3, YPO4, YORG, STBC, YCLL, XCLA, ZCAE

5 , ZMGE, ZSOE, ZPOE, ZOGE, ZCLE, YCAI, YMGI

5 , YSOI, YPOI, YOGI, YCLI, CION

6 ,D111, QWU, YNU, YKU, YNH, YNH4, STPG, OSMU, PHA I

6 , $\mathrm{PHU} 1, \mathrm{PHU}, \mathrm{YNH} \not$, YTA $\varnothing, \mathrm{CPRX}, \mathrm{YTA}, \mathrm{PHU} 2$

7 ,CHEI, CBEI, D129, ADH, ALD, THDF, GFR, ADH $\varnothing$, ALD, , GFR

7 ,COAD, ACTH, CKAL, CPVL, CNAL, CPAL, AIDI

8 ,DWE, DWW , DZN, DZK, DZCL, D150,D151, D152, "TLOOP, DW

\& ,TG, TMAX, TMI, TMA, DTG, DTAS, DT

\& ,ZELAG2, ZELAG3, ZFLAG4, REQ, ERR, BUE (IDQ)

\& ,D267, TUUR, TDAG, D270, REQ1, REQ2, REQ3, REQ4

\& ,REQ5, REQ6, REQ7, REQ8, REQ9, REQ1 $\not$

\& , REQ11, REQ12, REQ13, REQ14,D285,D286,D287,D288,D289,D29

DATA CPO4/1.5849E-7/, CORG,/5.011.89E-5/

C

$\$$, YCA, YMG, YSO4/. $907, .098, .962 /$

C

5

CONTINUE

$\mathrm{ERR}=0$.

$\mathrm{T}=\mathrm{T}+\mathrm{DT}$

! IN MIN!

C

C

c

$c$

10 CONTINUE

$\propto C O g=V B$

$Q 00=\propto C O Q+1$.

$\mathrm{PAS}=0 \mathrm{COO} \theta^{\star \mathrm{RTOT}}+2 \phi$.

PVS $=0 \mathrm{COQ} / \mathrm{KR} \quad-10.33$ 
$\mathrm{PAP}=Q \mathrm{QOO} * \mathrm{KMOP}+8$

$\mathrm{PVP}=0 \mathrm{COY} / \mathrm{KL}-16$.

IF (PUS.LT. ..) PUS $=$.

IF (PUP. LI . 9.) $P V P=9$.

C

C REQUESTS

IF (PAS.LT.85. AND. REQ14.NE *-14.) REQ14=14.

IF (RAS.LT. Ø.) $\mathrm{ERR}=-5$.

IF (PAS. GI. 250.) ERR=5.

IF (ERR.NE. D.) GONO 9,0\%ळ

C.

$\mathrm{C}$

$\mathrm{C}$

39

C REQUESTS

BODY FLUIDS

CONTINUE

DV $=Q I N-V I N / 1 \varnothing$.

$\mathrm{VIN}=\mathrm{VIN}+\mathrm{DV} * \mathrm{DT}$

$D V=V T N / 1 \phi_{*}+Q V I N+Q M W P-Q T W L-O W U$

$\$-Q C E R+Q L F$

$\mathrm{WP}=\mathrm{VP}+\mathrm{DV} * \mathrm{DT}$

IF (VP.LP. .1) $\mathrm{VP}=$. I

$\mathrm{VB}=\mathrm{VP}+\mathrm{VRBC}$

$\mathrm{VEC}=\mathrm{VP}+\mathrm{VIF}$

IF (VEC.LE. 6. .) $\mathrm{ERR}=-4$.

IF (VEC.GT. 3ด.) $E R R=4$.

IF (ERR.NE.ด.) GOTO $9 \not Q \varnothing \emptyset$

$\mathrm{HT}=\mathrm{VRBC} / \mathrm{VB}$

$D V=Q C F R-Q L F-Q I C$

C

$\mathrm{VIF}=\mathrm{VIF}+\mathrm{DN} * \mathrm{DT}$

- F31, F32

$\mathrm{X}=\operatorname{VIE} / 8.8$

$\operatorname{IF}(X . L T . .9) \quad P I F=-15$.

$\operatorname{IF}((X . G E . .9)$.AND. (X.LT.1.) ) PIF $=87 * *-93.3$

IE ( (X.GE. 1.) . AND. (X.LT.2.))

$\$$ PIF $=-6.3 * \operatorname{EXP}(10 . * \operatorname{ALOG}(\operatorname{ABS}(2 .-X)))$

If $((2 .-X) . E Q ., 0) \quad E R R=$.6 .

IF (ERR.NE. D.) GOTO 9 .

$\mathbb{I E}(\mathrm{X} . \mathrm{GE} .2.) \mathrm{PIF}=\mathrm{X}-2$.

OLF $=.062 * 24 . /(1 .+\operatorname{EXP}(-.4977 *$ PIF $))$

C - $-F 33, F 34, F 35$

$\mathrm{PC}=(\mathrm{PAS}+\mathrm{PVS} * \mathrm{CRAV}) /(1 .+\mathrm{CRAV})$

$\mathrm{PPCO}=\mathrm{XPP}^{*} .4$

$\mathrm{PICO}=\mathrm{XPIE} * 25$

QCFR $=(\mathrm{PC}-\mathrm{PIF}-\mathrm{PPCO}+\mathrm{PICO}) \star \mathrm{CFC}$

YPLC $=(\mathrm{XPP}-\mathrm{XPIF}) * 2.768 \mathrm{E}-6 * \mathrm{PC} * 2$

YPLF $=$ XPIF*QLF

$Y P L V=X P{ }^{*} \cdot 1001047-.0329$

YPLG $=(\mathrm{XPP}-\mathrm{ZPLG}) *$ बarg23

$\mathrm{DZ}=$ YPLF-YPLV-YPLG-YPLC

$\mathrm{ZPP}=\mathrm{ZPP}+\mathrm{DZ} \mathrm{Z}^{\star} \mathrm{DT}$

$\mathrm{XPP}=\mathrm{ZPP} / \mathrm{NP}$

$Y P G=(X P I F-Z P G) * .00257$

$\mathrm{DZ}=\mathrm{YPLC}-\mathrm{YPLF}-\mathrm{YPG}$

ZPIF $=Z \mathrm{ZPIF}+\mathrm{DZ} * \mathrm{DT}$ 
C REQUEST

$$
\begin{aligned}
& \mathrm{XPIF}=\mathrm{ZPIF} / \mathrm{NIF} \\
& \mathrm{DZ}=(\mathrm{XPIF}-\mathrm{ZPG}) / 15 \not . \\
& \mathrm{ZPG}=\mathrm{ZPG} . \mathrm{DZ} * \mathrm{DT} \\
& \mathrm{DZ}=(\mathrm{XPP}-\mathrm{ZPLG}) / 24 . \\
& \mathrm{ZPLG}=\mathrm{ZPLG}+\mathrm{DZ} * \mathrm{DT}
\end{aligned}
$$

IF (HT. IE. 35. .AND.REQ9.NE. -9.) REQ9=9.

IF (HT. LE. 3\%. .AND. REQ10. NE. -1\%.) REQ1 $\theta=1 \%$.

C

C

$\mathrm{C}$

ELECTROLYTES

40

\section{CONTINUE}

$\mathrm{DZ}=\mathrm{YNIN}-\mathrm{YNU}+\mathrm{YHI}+\mathrm{CION} / 1440$.

$\mathrm{ZNE}=\mathrm{ZNE}+\mathrm{DZ} * \mathrm{DT}$

$\mathrm{XNE}=\mathrm{ZNE} / \mathrm{NEC}$

$\mathrm{QIC}=(\mathrm{XKI}+1 \not 0.5-\mathrm{XINE}-\mathrm{XKE}-\mathrm{XGLE}) * \mathrm{CSM}$

$\mathrm{VIC}=\mathrm{VIC}+\mathrm{QIC} \mathrm{DT}^{\mathrm{DT}}$

$\mathrm{F} 41 \mathrm{~A}=\mathrm{XKE} /(56.744-7.06 * \mathrm{PHA})$

IF (F41A. LE. O.) ERR=1.

IF (ERR.NE. $\varnothing$.$) GOTO 9 \not \varnothing \emptyset \emptyset$

$\mathrm{F} 41=1 .+.5 *$ ALOGIg $(\mathrm{F} 41 \mathrm{~A})$

$D Z I=(F 41 * 28 \not \varnothing 0 .-2 K I) *$ CKEI + CGL $3 *$ YGLS

$\mathrm{ZKI}=\mathrm{ZKI}+\mathrm{DZI} * \mathrm{DT}$

$\mathrm{DZ}=\mathrm{YKIN}-\mathrm{YKU}-\mathrm{DZI}$

$\mathrm{ZKE}=\mathrm{ZKE}+\mathrm{DZ} * \mathrm{DT}$

$\mathrm{XKE}=\mathrm{ZKE} / \mathrm{VEC}$

C CHECK FOR REQUEST

IF (XKE.GE. 9.5. AND. REQ5. NE * -5.) REQ5=5.

IF (XKE.GT. 7. .AND.REQ6.NE. -6.) REQ6 $=6$.

IF (XKE.LE. 2. 5. AND. REQ7. NE. -7.) REQ7=7.

IF (XKE. LT. 2. AND. REQB.NE. -8.) REQ8=8.

$\mathrm{XKI}=\mathrm{ZKI}$ NIC

C

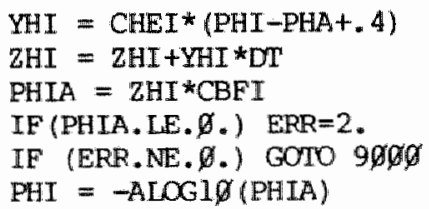

C

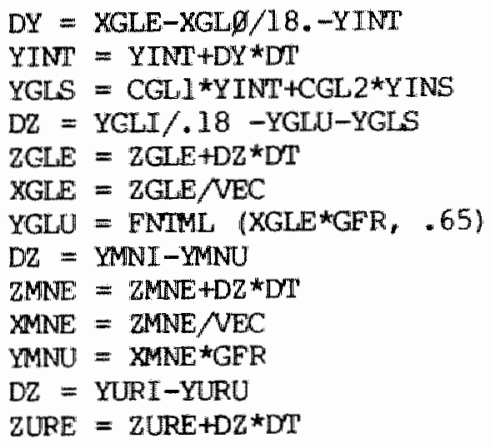


XURE $=$ ZURE, NTW

YURU $=X U R E^{*} \operatorname{CFP}^{\star} \cdot 6$

VTW $=$ VIC + VEC

OSMP $=1.86 *(X N E+X K E)+X G L E+X U R E+X M N E+9.73$

C

C

C

ION EXCRETION

$\mathrm{C}$

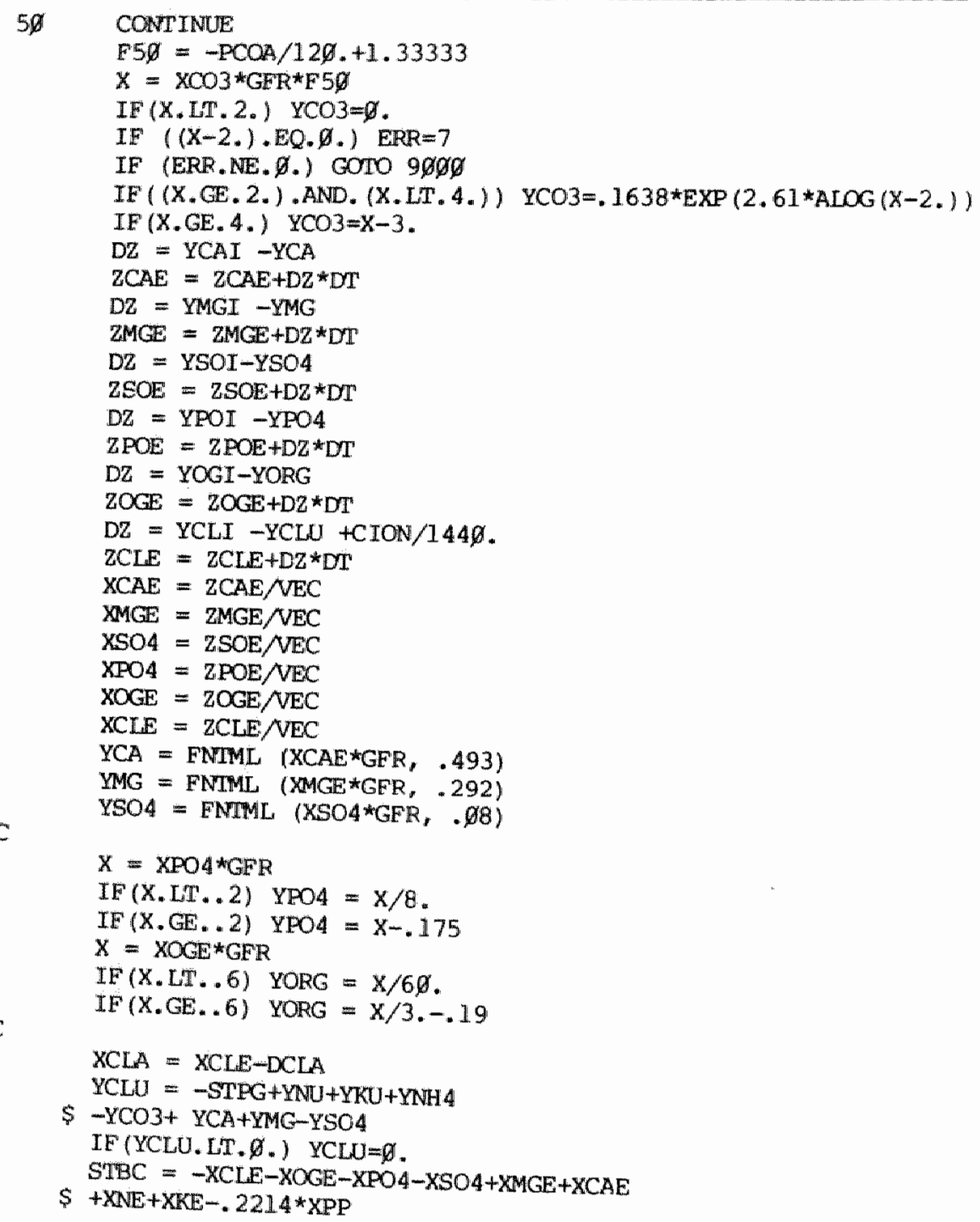


C

C

KIDNEY AND URINE BUEFER

C.

69

CONIINUE

GFR $1=\mathrm{GFR} * \mathrm{CPRX} * \mathrm{THDF}$

$\mathrm{YKD}=\mathrm{XKE} * \mathrm{GER} 1 * .5 * * 9 * .0178 * \mathrm{ALD} * \mathrm{XKE}$

$\mathrm{YNH}=\mathrm{XNE} * \mathrm{GFRI} * 5$

$\mathrm{YND}=\mathrm{YNH}^{*} \cdot 9-.69 * \mathrm{ALD}$

$Q W D=\left(1.86^{*}(\mathrm{YND}+\mathrm{YKD})+\mathrm{YGLU}+\mathrm{YURU}+\mathrm{YMNU}+.32\right) / \mathrm{OSMP}$

QWU $=Q_{W D} *(1,-.9 * \mathrm{ADH})$

OSMU $=(1.86 *(\mathrm{YNU}+\mathrm{YKU})+\mathrm{YGLU}+\mathrm{YURU}+\mathrm{YMNU}) / \mathrm{QNU}$

C

- F61, F62, F63

$\mathrm{F} 61=-.5 \star \mathrm{PHU} 1+4$.

$\mathrm{F} 62=-2.5 * \mathrm{PHA}+19.5$

IF (PHU2. LT. 4*) F63=\%.

IF ( (PHU2.GE. 4. ) .AND. (PHU2. LT. 5. ) ) F63=PHU2-4.

IF (PHU2. GE. 5) F63=1.

$\mathrm{YNH} 4=\mathrm{YNH} g{ }^{*} \mathrm{~F} 61$

$\mathrm{YTA} 1=\mathrm{YTA} \not * \mathrm{~F} 62 * \mathrm{~F} 63$

$\mathrm{YNDD}=-Y \mathrm{CO}+\mathrm{YNH} 4+\mathrm{YTA} 1$

IF (YNDD. LT.. .) YNDD $=\varnothing$.

$\mathrm{YNU}=\mathrm{YND}{ }^{\star} .116-\mathrm{YNDD}$

IE (YNU. LT. $\varnothing.) \quad \mathrm{INU}=\varnothing$.

$\mathrm{YKU}=\mathrm{YKD} * .39$

C

$\mathrm{DP}=(\mathrm{PHA}-\mathrm{PHA} 1) / 2 \not 0 \%$.

$\mathrm{PHA} 1=\mathrm{PHAl}+\mathrm{DP} * \mathrm{DI}$

$\mathrm{DP}=(\mathrm{PHU}-\mathrm{PHU1}) / 3 \not \varnothing \not$.

$\mathrm{PHUI}=\mathrm{PHU} 1+\mathrm{DP} * \mathrm{DT}$

$\mathrm{DP}=(\mathrm{PHU}-\mathrm{PHU} 2) / 20$.

$\mathrm{PHU} 2=\mathrm{PHU} 2+\mathrm{DP} * \mathrm{DT}$

YTA $=$ YTA1 +. OOD1*AID +. 999

STPO $=$ YPO4*(1.* 1./(1.+ $\operatorname{EXP}((6.8-\mathrm{PHA}) * A L O G(1,0)))$.

$S T P G=-Y T A+S T P O+Y O R G$

$\mathrm{C}$

IF (STPG. LT. $\varnothing$.$) SIPG =\varnothing$.

$\mathrm{C}$

C

$A=S T P G-Y P O 4$

$B=A *(C P O 4+C O R G)-(C P O 4 * Y P O 4+C O R G * Y O R G)$

$\mathrm{C}=\mathrm{CPO} 4 * \mathrm{CORG} *(\mathrm{~A}-\mathrm{YPO} 4-\mathrm{YORG})$

$\mathrm{D}=\mathrm{B} * \mathrm{~B}-4 . * \mathrm{~A}^{*} \mathrm{C}$

IF (D. LE. Ø.) D $=\varnothing ., 9 \varnothing \emptyset \emptyset 1$

$\mathrm{HU}=.5 *(-\mathrm{B}+\mathrm{SQRT}(\mathrm{D})) / \mathrm{A}$

IF (HU. GT. 1.E-4) HU=1.E-4

IF (HU. LT. 1.E-B) HUI=1.E-8

$\mathrm{PHU}=-\mathrm{ALOG} 10(\mathrm{HU})$

$\mathrm{C}$
$\mathrm{C}$
$\mathrm{C}$

KIDNEY CONTROL 
$7 \varnothing$

CONTTNUE

$\mathrm{DA}=(-\mathrm{CPAD} *(\mathrm{PVP}-4)+.\operatorname{COAD} *(\mathrm{OSMP}-287)$.

$\$-A D H Q / 39$.

$A D H D=A D H B+D A \star D T$

C

$\operatorname{ADH}=1.1 /\left(1 .+\operatorname{EXP}\left(-.5^{*}(\operatorname{ADH}(\phi+4.6015))\right)\right.$

$C$

$D L=(A C T H-1$.$) HCKAL* (X K E-4.5)-C P V *$ (PVP-4.)

$\$-C N A L *(Y N H-1.4)-C P A L *(P A S-199 \%$.)

C 190 MIN DELAY: IN:DL OUT:ALD1 (DELAYED)

$\mathrm{C}$

D151 $=\mathrm{DL}$

CALL DELAY (DL, ALD1, 1,96. ,DT, BUE)

$\mathrm{C}$

$\mathrm{C}$

$D A=(A L D \perp-A L D Q) / 39$.

$A I D Q=A L D Q+D A * D T$

$A L D=10 . /(1 .+\operatorname{EXP}(-.4394 *(\operatorname{ALDQ}-5))$.

C

$\mathrm{x}=\mathrm{PPCO} / 28$.

THDF $=-5 *(X-1)+$.1 .

IF (X.GT.1.) THDF $=1$.

C

$X=$ PAS

IF (X.LT. 49.) GFRI $=\varnothing$.

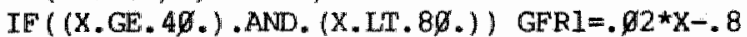

$\operatorname{IF}\left(\left(\mathrm{X}_{.} \mathrm{GE} .80.\right)\right.$.AND. (X.LT. 199.$\left.)\right) \mathrm{GFR} I=-.0995 *(\mathrm{X}-190) * * 2+$.1 .

IF (X.GE. 1 90.$)$ GFRI=1.

C

$\mathrm{GFR}=\mathrm{GFR}{ }^{*} \mathrm{GFR} 1$ *VEC, $11 . \emptyset$

C

C

C

$\mathrm{C}$

90

C

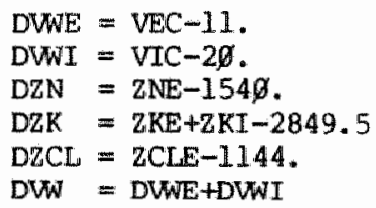


C $-\mathrm{E} 21$

C

IE (PO2A.III. 33.) $\mathrm{PO} 2 \mathrm{~A}=33$.

$\mathrm{VR}=.22 * 10 . * *(9 .-\mathrm{PHA})+.262 * 32 .-18.238$

$\$+.2125 *(1 .+17 . /(\mathrm{PO} 2 \mathrm{~A}-32)) *.(\mathrm{PCOA}-32$.

IF (VR.LE. $\not \partial.) \quad V R=. \not 22$

$\mathrm{DV}=\left(5.0^{*} \mathrm{VR} * \mathrm{KLF}-\mathrm{VI}\right) / \mathrm{TRSP}$

$\mathrm{VI}=\mathrm{VI}+\mathrm{DV} * \mathrm{DT}$

IF (KVI.GI. a.) VI= KVI

C

C

C

PHAA $=X C 03 /(.93 * \mathrm{PCOA})$

IF (PHAA. LE. $\emptyset . \emptyset$ ) ERR=3.

IF (ERR. NE. 9. ) GOTO 9990

$\mathrm{PHA}=6.1+$ ALOGID $($ PHAA $)$

C

C $\quad$ F23

C

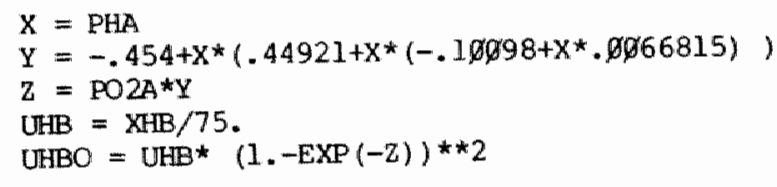

C

C $-\cdots 24$

$C$

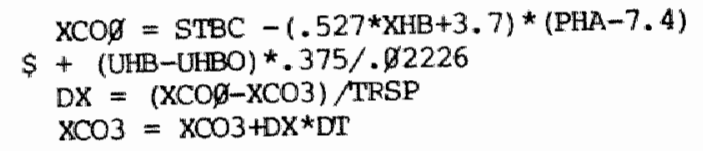

C

C

C OXY:

DCLA $=$ XCO3-STBC

UO2A $=\mathrm{UHBO}+3.168 \mathrm{E}-5 * \mathrm{PO} 2 \mathrm{~A}$

$\mathrm{DU}=((\mathrm{UO2} 2 \mathrm{~A}-\mathrm{UOZZV}) * \mathrm{OCO}-\mathrm{MRO} 2) / \mathrm{NTW}$

$\mathrm{DO} 2 \mathrm{~V}=002 \mathrm{~V}+\mathrm{DU} * \mathrm{DT}$

$\mathrm{DF}=($ (UO2V-UO2A)*CRUF+(FO2T-EO2A $) * \mathrm{VI}) / 3$.

$\mathrm{FO} 2 \mathrm{~A}=\mathrm{FO} 2 \mathrm{~A}+\mathrm{DF} * \mathrm{DT}$

$\mathrm{PO} 2 \mathrm{~A}=\mathrm{FO} 2 \mathrm{~A} * \mathrm{PBL}$

C

C MESSAGES OR REQUESTS:

C TEST IF VARIABLES ARE OUT OF RANGES:

IF (PHA. GT . 6. 95. AND. PHA. LT. 7. 95. AND. REQ1. NE. - 1.) REQ1=1.

IF (PHA. LT. 6. 95.AND. REQ2. NE. -2.) REQ2 =2.

IF (PHA. LT. 6. 9. AND. REQ 3. NE . - 3.) REQ3=3.

IF (PHA. LT . 6. 8. AND. REQ4. NE. - 4.) REQ4 4 .

C

C

C

TESTING FOR ERRORS AND REQUESTS

909Q CONDINUE

IF (ERR. EQ. \%. G) GOTO $99 \varnothing$ 
IIE (ERR.LT.,.$\varnothing)$ MUMBER $=42 \not 2+2 *(\operatorname{INT}(\mathrm{ABS}(\mathrm{ERR})))$

IF (ERR.GT* $\varnothing . \varnothing) \quad$ NLMBER $=4560+2 *($ INT $(E R R))$

CALL LEES (NUMBER)

CALC LEES (419)

CoTO 19g9

966 IF (REQTST.EQ.2.) COTO 910

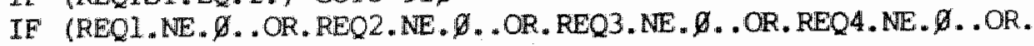

+ REQ5.NE. \%. .OR.REQ6.NE. O.) REQTST $=1$.

IF (REQTST.EQ. W. GOTO 1909

CALL CURSIO $(8,0)$

CALL ERASIO (D)

CALL CURSID $(8,0)$

REQTST $=2$.

910 ITIM=INT (W/6,

IE (REQ1.EQ.1.) WRTTE (7,911) ITIM

IF (REQ1.EQ.1.) CALL LEES (353)

IF (REQ1.EQ.1.) $\mathrm{REQI}=-1$.

IF (REQ2.EQ.2.) WRITE $(7,911)$ ITIM

IF (REQ2. EQ.2.) CALL LEES (356)

IF $(\mathrm{REQ} 2 . \mathrm{EQ} .2.) \mathrm{REQ} 2=-2$.

IF (REQ3.EQ.3.) WRITE (7,911) ITIM

IF (REQ3.EQ.3.) CALL LEES (358)

IF (REQ3.EQ.3.) REQ3 $=-3$.

IF (REQ4.EQ.4.) WRITE (7,911) ITTM

IF (REQ4.EQ.4.) CALLL LEES (369)

IF (REQ4.EQ . 4.) REQ4=-4.

IF (REQ5.EQ.5.) WRITE (7,911) ITIM

IF (REQ5.EQ.5.) CALL LEES (363)

IF (REQ5.EQ.5.) REQ5 $=-5$.

IF (REQ6.EQ.6.) WRTTE $(7,911)$ ITIM

IF (REQ6.EQ.6.) CALL LEES (36.6)

IF (REQ6.EQ.6.) REQ6 $=-6$.

IF (REQ7.EQ.7.) WRTTE $(7,911)$ ITIM

IF (REQ7.EQ.7.) CALL LEES (369)

IF (REQ7. $\mathrm{EQ} .7.) \quad \mathrm{REQ} 7=-7$.

IF (REQ8.EQ.8.) WRITE (7.911) ITIM

IF (REQ8. EQ.8.) CALL LEES (371)

IF (REQ8. EQ.8.) REQB =-8.

IF (REQ9.EQ.9.) WRITE $(7,911)$ ITIM

IF (REQ9.EQ.9.) CALL LEFS (374)

IF (REQ9. EQ.9.) REQ9=-9.

IF (REQ10.EQ.1\%.) WRITE (7,911) ITIM

IF (REQ10.EQ.10.) CALJ. LEES (377)

IF (REQ1ด.EQ.10.) REQL $9=-1 \%$.

IF (REQ11.EQ.11.) WRTTE (7.911) ITTM

IF (REQ11.EQ. 11.) CALL LEES (38Q0)

IF (REQ11.EQ.11.) REQ11=-11.

IF (REQ12.EQ.12.) WRITE $(7,911)$ TTIM

IF (REQ12. EQ. 12.) CALL ILES (383)

IF (REQ12.EQ.12.) REQ12 $=-12$.

IF (REQ13.EQ.13.) WRITE (7.911) ITIM

IF (REQ13.EQ.13.) CALL LEES (385)

IF (REQ13.EQ.13.) REQ1 $3=-13$.

IF (REQ14.EQ.14.) WRITE $(7,911)$ ITIM

IF (REQ14.EQ.14.) CALIL LEES (3B8)

IF (REQ14.EC. 14.) REQ14 $=-14$.

911 FORMAT $(1 \mathrm{X}, \mathrm{I6}$, " uur: "\$)

10\%O CONITNUE

RETURN

END 
Appendix 6.1

De opbouw van het model

De opzet van het model is bij de hiervolgende beschrijuing toegespitst op het voorbeeld uit figuur 6.4. Als uitgegaan wordt van de halfwardetijiden (THALPH) voor de a-fase en (THBETA) voor de b-fase, van b en van de concentratie even na toediening van de dosis (AENB) dan worden er op 2 verschillende manieren de concentratie in het centrale compartiment berekend (de dosis D is in de FORTRAN notatiewijze DOS).

Dat gebeurt ten eerste analytisch en kan door de student op het beeldscherm worden weergegeven als referentiecurve. In FORTRAN ziet de functie voor de concentratie in het eerste compartiment (CCD) er als volt dit: :

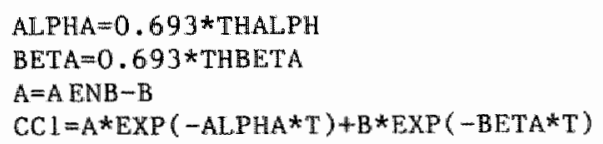

Ten tweede worden de concentraties ( $C 1$ en $C 2$ ) in de beide compartimenten van het open twee compartimentenmadel berekend net de gebruikelijke integratiemethode; in FORTRAN:

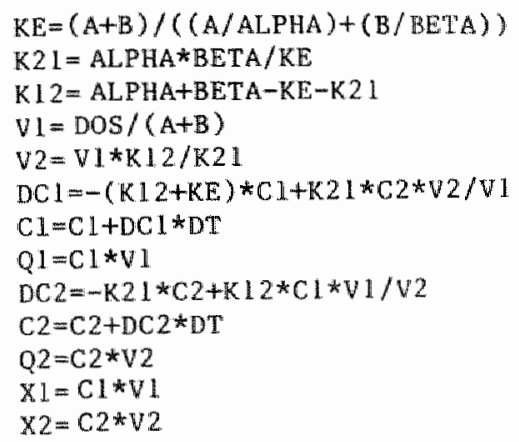

Tot slot worden de logaritmen van de concentraties CClL, ClL en C2L, berekend. In FORTRAN:

$$
\begin{aligned}
& C 1 L=A L O G 10(\mathrm{CH}) \\
& C 2 L=A L O G 10(\mathrm{C} 2) \\
& C C 1 L=A L O G 10(\mathrm{CC} 1)
\end{aligned}
$$

Beide berekeningswijzen, de analytische en de modelmatige oplossing, dienen overeen te konen. Met het computersimulatieprogramma FARMA en de hier beschreven versie van het model, kan ook nog gekeken worden naar de klaring (CLEARC), naar het verdelingsvolume (steady state methode en oppervlakte methode resp. VD en VDAREA), naar het 
oppervlak onder de curve (AREA) en naar de hoeveelheid van de stof die het lichaan verlaten heeft (XE) (Greerblatten Koch-Weser, 1975).

In FoRTRA zlet dat er in relatie tot het concentrat leverloop bij het

twee compartimentenmodel als volgt wit:

CLEARC $=V 1 * K E$

$V D=V 1 *(1+K 12 / K 21)$

AREA $=$ A/AL.PHA+B/BETA

VDAREA $=$ DOS / (BETA*AREA) ! (oppervlak methode)

$X E=D O S-X 1-X 2$

Het computers imulat leprograma FARMA heeft een systeem dat maximal 6 verschlllende modellen m.b.t. farmacokinetiek (c.q. 6 versies) kan bevatien.

Het klezen van een model gaat middels het systeem van het kiezen van een andere casus (zie hoofdstuk 2 ).

op dit moment bevat het programa een 2 compartimentenmodel met de snelheidsconstanten resp. met $\alpha, B$, A en $B$ als onafhankelijke constanten en een model waarbij een metaboliet gevormd wordt. 
Append1x 6.2

Source van het model.

$\mathrm{C}$

SUBROUTINE MODEL

REAL $\mathrm{KE}, \mathrm{K} 12, \mathrm{~K} 21$

C

COMMON MODEL/T, DT, TMAX, TMI, TMA, TO, DTG, DTAS, K12, K21, KE

$+\quad$,CC1, THALPH, THBETA, DOS, B, C1, C16, A. PHA, BETA, A, AENB

C

$+\quad, \mathrm{X} 1, \mathrm{X} 2, \mathrm{XE}, \mathrm{V1}, \mathrm{VD}, \mathrm{V2}, \mathrm{AREA}, \mathrm{VDAREA}, \mathrm{CLEARC}, \mathrm{DC} 1, \mathrm{Q1}, \mathrm{DC} 2, \mathrm{C2}$

C

ALFHA $=0.693 /$ THALPH

BETA $=01.693 /$ THBETA

$A=A E N B-B$

$C C I=A * E X P(-A L P H A * T)+B * E X P(-B E T A * T)$

$\mathrm{KE}=(\mathrm{A}+\mathrm{B}) /((\mathrm{A} / \mathrm{ALPHA})+(\mathrm{B} / \mathrm{BETA}))$

$\mathrm{K} 21=\mathrm{ALPHA} * \mathrm{BETA} / \mathrm{KE}$

K12=ALPFIA +BETA-KE-K21

$\mathrm{Vl}=\mathrm{DOS} /(\mathrm{A}+\mathrm{B})$

$\mathrm{V} 2=\mathrm{V} 1 * \mathrm{~K} 12 / \mathrm{K} 21$

$\mathrm{DCl}=-(\mathrm{K} 12+\mathrm{KE}) * \mathrm{C} 1+\mathrm{K} 21 * \mathrm{C} 2 * \mathrm{~V} 2 / \mathrm{N} 1$

$\mathrm{Cl}=\mathrm{Cl}+\mathrm{DCl} * \mathrm{DT}^{\prime}$

$\mathrm{X} 1=\mathrm{C} 1 * \mathrm{~V} 1$

$\mathrm{DC} 2=-\mathrm{K} 21 * \mathrm{C} 2+\mathrm{K} 12 * \mathrm{C} 1 * \mathrm{~V} 1 / \mathrm{N} 2$

$C 2=C 2+D C 2 * D T$

$\mathrm{X} 2=\mathrm{C} 2 * \mathrm{~V} 2$

C

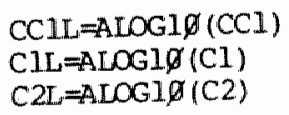

C

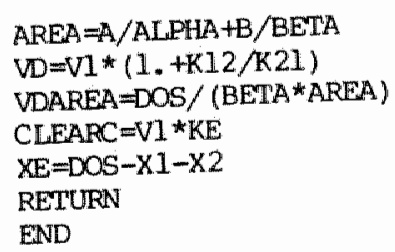


Appenditr 7.1

Compartimentenstructuur van MACDOPE
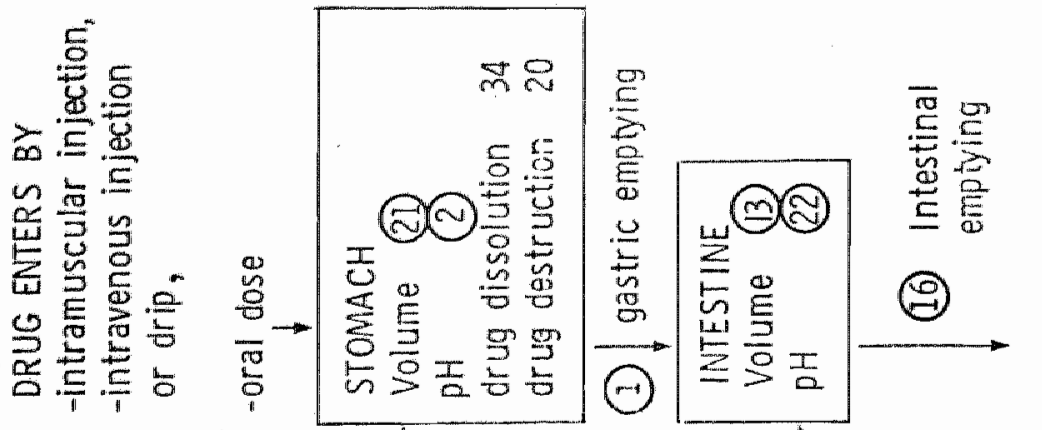

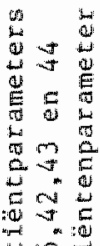

it

un 2

Q: $m$.

N

$\because \infty$

$\stackrel{0}{0} \stackrel{0}{0}$

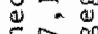

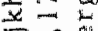

$\pm 0$

d)

$30 \mathrm{~cm}$

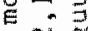

(4) $\lim _{0 \rightarrow 1}^{\infty}$

in $\rightarrow$

L $\longrightarrow$

$>20$

का

$+5$.
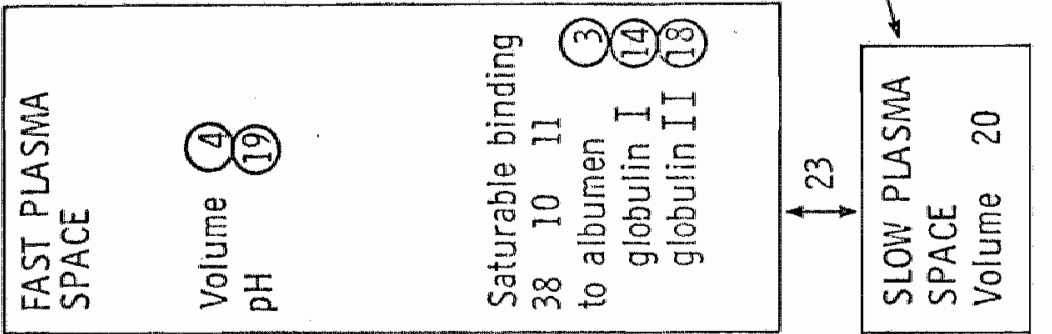

in

(4)

is on

a) 1

过

D

0

这

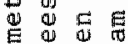

(4) 5

An on

\& $c \cong$

$0 \unlhd$

造. 㟧

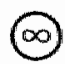

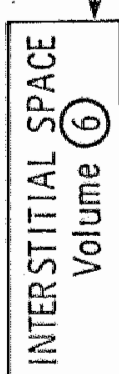

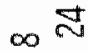

(8)

횡 m

허는 동 도응

눈읗호음

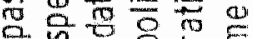

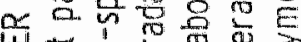

ए世

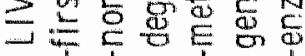
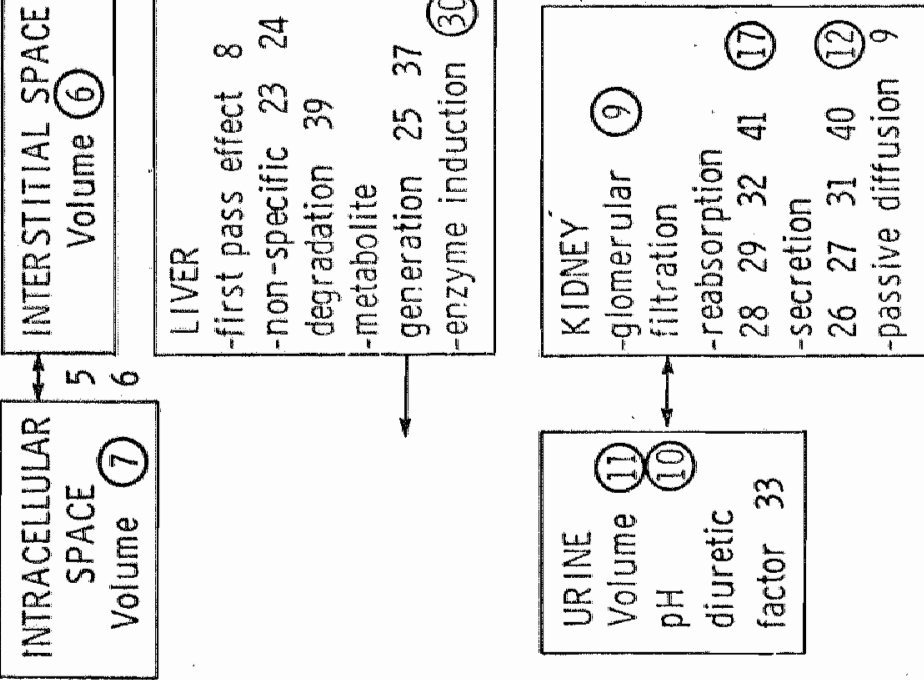

a 10

$>$ का की

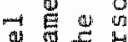

(4)

E 0 .

1 ए

a $\rightarrow$ in

क्षे

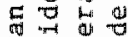

$>$ E

4 o w 0

3 然

प

4 व

$\Rightarrow=30$

밍

म. 피

a 3

ED प

is 0

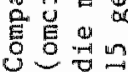


Appendix 7.2

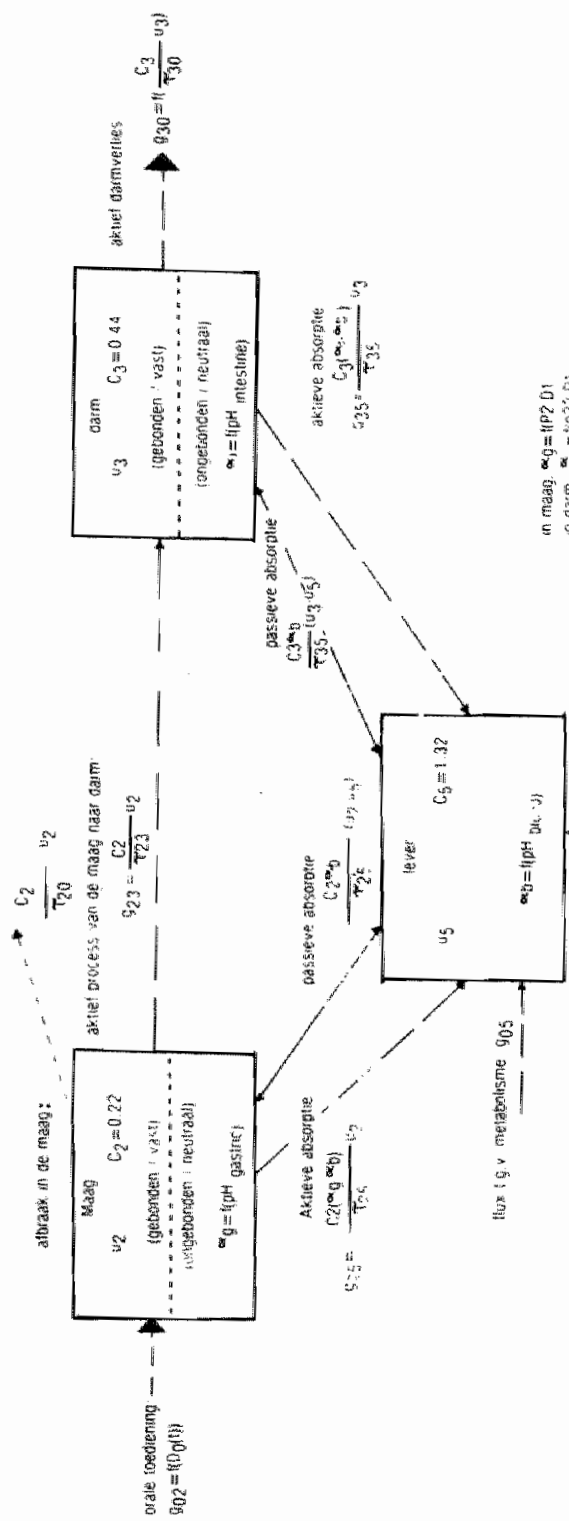

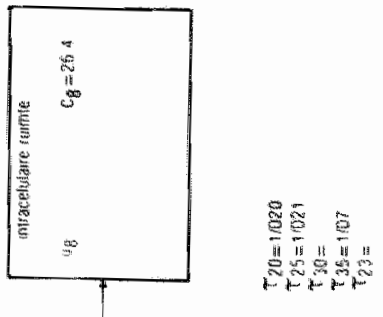

ind

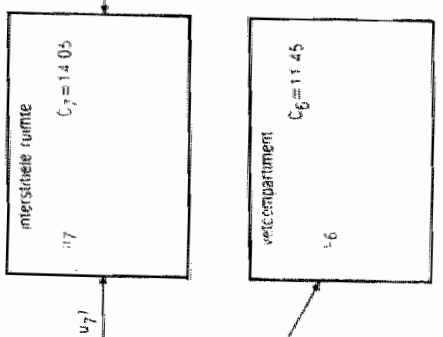

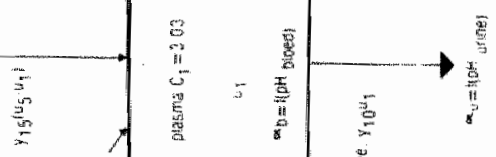
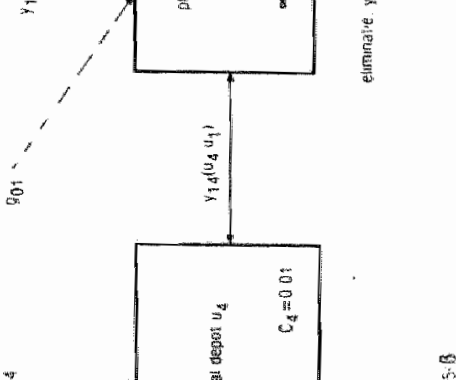

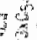

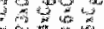

, till

Blokschema van het model van MACDOPE met de 8 compartimenten bil een jonge, mannelijke vrijwilliger.

$c_{1} t / m c_{8}$ zijn volumina in liters: $y_{1 j} z$ ijo flow's in ml/h; $g_{i j} z$ jo fluxer in $\mathrm{mg} / \mathrm{h}$ en $u_{1} \mathrm{t} / \mathrm{m} \mathrm{u}_{8} 2 \mathrm{i}$ In concentraties behorende bij één geneesmiddel. (Voor uideg wan de parameters zle de tekst). 
Appendix 7.3
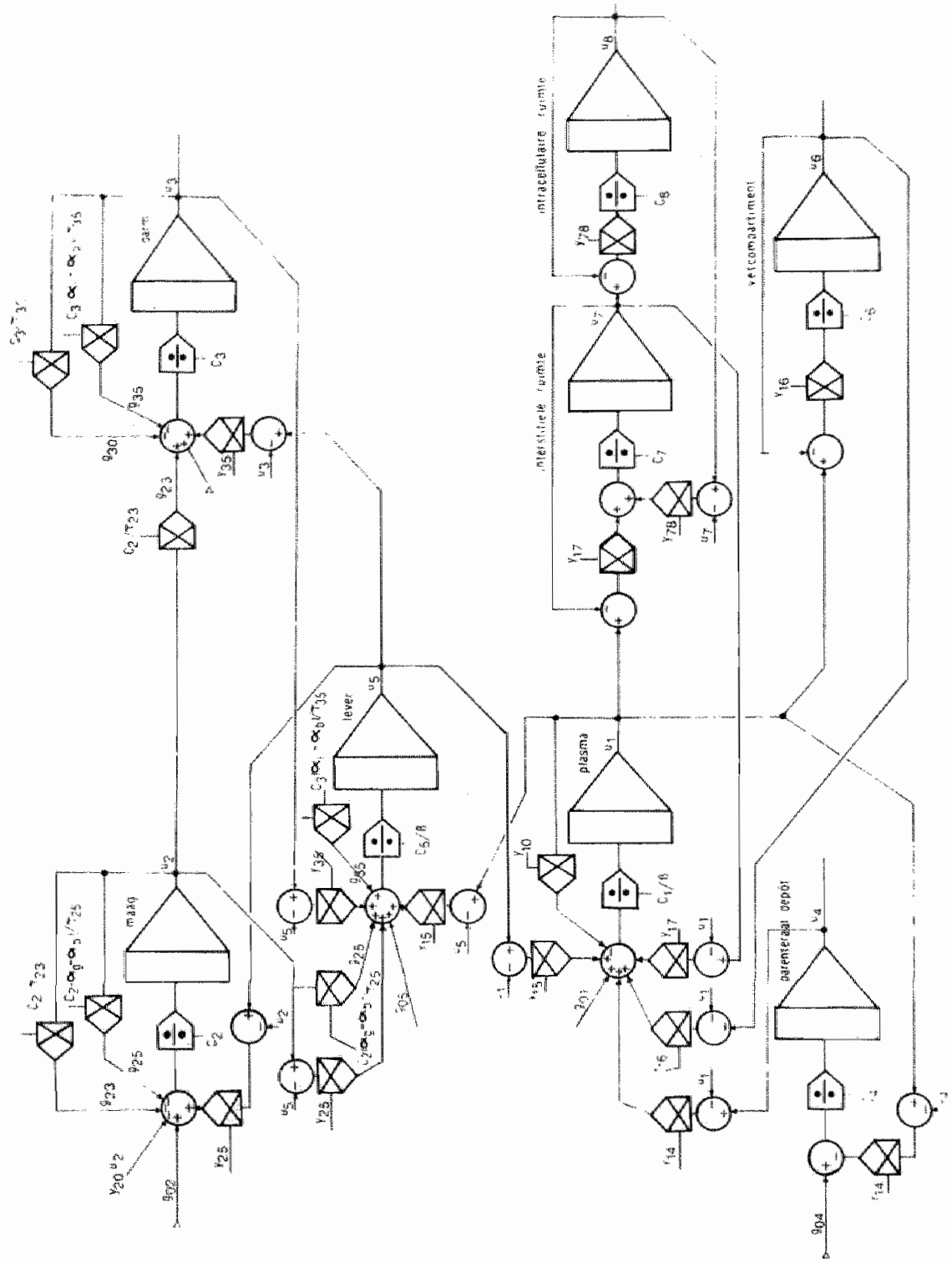

Analoge noteringswijze van de 8 differential wergelijkingen van het model van MACDOPE met de interaktiemogelijkheden tussen de compartmenten voor wat betreft de passieve $\left(y_{i j}\right)$ en het aktieve $\left(g_{i j}\right)$ geneesmiddelentransport. (Zie voor een verklaring van de symbolen y, $\mathrm{C}, \mathrm{g}$, e.d. de tekst). 
Appendix 7.4
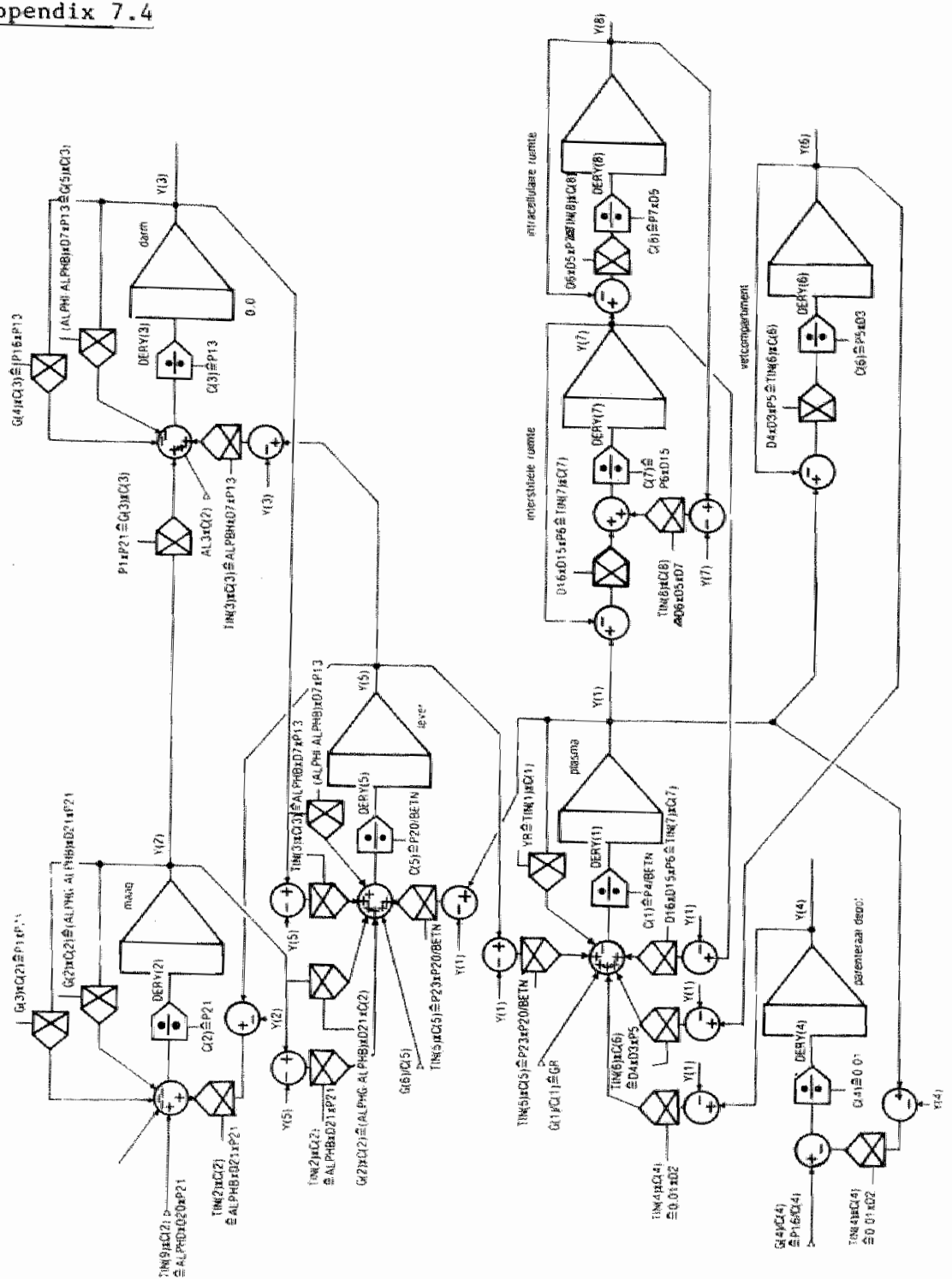

Analoge noteringsw 1 jze van model van MACDOPE met patientparameters en geneesmiddelparameters als interventiemogelijkhelid (met: FoRTRAk nomenclatuur). In dit relatieschema is de invloed en het (de) aangrijping:punten) van een patientparameter of geneesmiddelparameter direct te zien. Vaak blijkt een flow of een flux nog van een niet direct voor de hand 11 ggende andere parameter afhankelijk te $z i j n$. 


\section{Appendix 7.5}

\section{Patientenarameters}

1. Maagont ledingssnetheid PI

2. Maag pH (pHgastric) 1

3. Plasma albumine concentratie $(\mathrm{g} / 100 \mathrm{ml}) \quad$ P3

4. Nolume van het "snelle" plasmacompartiment (1) P4

5. Grootte wan het vetcompartiment (gewicht van het vet)(kg) P5

6. Interstitiele vloeistofcompartiment grootce (1) P6

7. Intracellulaire vloeistofcompartiment grootte (1) P7

8. Enzymatische leverfunctie P8

9. Glomerulaire filtratiesnelheid $(1 / \mathrm{h}) \quad$ P9

10. Urine $\mathrm{pH}$ ( $\mathrm{pH}$ urine)
PIO

11. Urineproductie $(1 / h)$

12. Tubulaire functie P:2

13. Dunne darm wolume (1) $\mathrm{C}_{3} \quad \mathbb{P} 3$

14. Gehalte aan plasma globuline $\mathbb{1}(\mathrm{g} / 100 \mathrm{ml}) \quad$ Pl.

15. Relatief 1ichaamsgewicht t.o.v. $70 \mathrm{~kg}$ (standaard) pls

16. "Intestinal motility rate" $(\mathbb{1} / \mathrm{h})$ * p

17. Tubulaire reabsorptie functie Pl7

18. Gehalte aan plasma globuline $2(\mathrm{~g} / 100 \mathrm{ml}) \quad$ Pl8

$\begin{array}{ll}\text { 19. Bloed } \mathrm{pH}\left(\mathrm{pH}_{\mathrm{b} l o e d}\right) & \text { Plg }\end{array}$

20. Grootte van het levercompartiment (1) P20

21. Maagvolume (1) $\mathrm{C}_{2} \quad$ P21

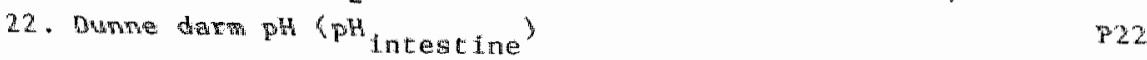

23. "Rate of equilibrium of slow compartment" $(1 / \mathrm{h}) \quad$ P2J

* Een aantal begrippen is niet vertald ondat ze in het programa spectfieke betekenis hebben. 
Appendix 7.6

\section{Geneesmiddelparameters}

1. $\mathrm{pK}$ van het geneesmididel

DI

2. "Absorption rate of parenteral deposit" $(1 / \mathrm{h}) \mathrm{f}\left(\mathrm{y}_{1 / 4}\right) \quad \mathrm{D2}$

3. Vet/water verdedingsratio

4. "Lipid equilibration rate" $(1 / \mathrm{h}) \quad \mathrm{f}\left(\mathrm{y}_{16}\right)$ D 4

5. "Intra/extracellulat distribution ratio" D.5.

6. "Intracellular equilibration rate" $(1 / \mathrm{h}) \quad \mathrm{f}\left(\mathrm{y}_{18}\right) \quad 06$

7. "Intestinal absorption rate" (1/h) 1/:35 D7

8. "Portal transfer ratio" $(0-1)$ D8

9. Renale tubulaire permeablititeit (1/h) D9

10. Maximum plasma bindingscapaciteit (mol/g) 019

11. Plasma bindingsconstante (1/mmol) Dll

12. Gangbare toedieningswijze (b.v. oraal=1) D12

13. Maximum van de gebruikelijke dosis (mg) Dl3

14. Minimum van de gebruikelijke beschikbare orale dosls (mg)Dl4

15. "Interstitial partition ratio" D15

16. "Interstitial equilibration rate" (1/h) $f\left(y_{17}\right) \quad$ DLG

17. Inclex die aangeeft of een stof zuur ( 1 ) of basisch (0) is D17

18. Mediaan voor de concentratie registratie en indeling op het scherm (mg/l) D18

19. $50 \%$ lecas concentratie niveau $(\mathrm{mg} / 1)$ D19

20. "Rate of destruction by gastric acid" (1/h) 1/r20. D20

21. "Castric absorption rate" (1/h) $1 / \pi 25 \quad 021$

22. Toxische concentratie (mg/1) D22

23. "Vmax" van lever enzymen $(\mathrm{mg} / \mathrm{h}) \quad 023$

24. Lever enzym dissociatie constante (1/mg) D24

25. "Liver conwersion rate into new drug" D25

26. "Tmax" van het renale excretlemechanisme (mg/mil) D26

27. Renale excretieassociatieconstante (1/mg) D27

28. "Tmax" van het renale reabsorptiemechanisme (mg/h) D28

29. Renale reabsorptieassociatie constante (h/mg) 029

30. Lever enzym inductie factor $(1 /(\mathrm{mg} / \mathrm{h}))$ D30

31. Renale excretie inhibitie factor, non-competitief ( $1 / \mathrm{mg}$ ) D31

32. Renale reabsorptie inhibitie factor, non-competitief (1/mg) 
33. Diurese factor ( $1 / \mathrm{mg})$

34. Uiteenvaltija van een stof (h)

vervolg geneesmiddelparameters (parameters zijn codes:0, 1, 2 etc.)

35. Route van product bij eerste orde levermetabolisme

$(I \approx$ door het plasma)

36. "Drug name cade of product of saturable liver metabolic process"

37. "Drug code" voor de metaboliet

38. Type eiwitbinding

39. Type interactie met lever enzym systeem

(non-specifieke "microsonal" systeem=1)

40. Type van renale excretie systeen (geen actieve excrete $=0$ )

41. Type van renale reabsorptie systeem D4l

42. Waar vindt toxische reactie plats? D42

43. War vindt letale werking plaats? 043

44. Moleculair gewicht

45. Route code voor product van levermetabolisme $(\mathrm{O}=\mathrm{dump} \mathrm{drug})$

46-50 Nilet in gebruik

51. "Drug sertal code number"

D51

52. "Drug name code number"

D52

\section{N.B.}

Het verdient anbeveling om bij gebruik van deze lijsten in de appendlces 7.3 en 7.4 na te gaan war een parameter in het werkellijke model aangrijpt. De parameter omschrijuing kan wel eens niet overeen komen met de functie die de parameter in het model heeft. 


\section{Appendix 7.7}

\section{Oriënterende casus}

Enibryo en toetus 2.1

Nagh -

Da政

\section{Orienterende casus met MACDOPE}

Ter arientatie wat het computers int 1 at ieprograma MCDope inhoudt kumb $U$ het beste cens een recept toedienem

- adr een gezonde wrijwilliger.

- $200 \mathrm{ng}$ aspirine, per os, an de 3 uur.

Teken de plasmaconcentratie van aspirine op het scherm. En natak een copte wan de kurve met belulp van hew copieerappamat (copy krop)

Wat ziet of op het scherm gebeuren ? -

Welke stof accumuleert ?

Wat zou de reden zijn?

Welke staf wordt het effectiefst in de urine uitgescheiden?

Doe hetzelfde experinent bij een gezonde vrijwilliger madr verander direct na het wischrojuen van het recept de urine pif (wan 5.5 thar 7.5 ).

Helk verschil ziet $U$ met het eerste experiment ? $\ldots$

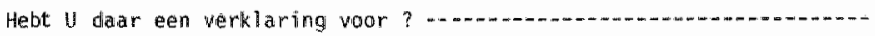

De verbijiftijd in het bloed kumen we beschrijuen met het begrip hal fuadratije.

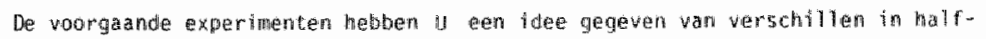
wartetijoem. 


\section{Appendix 7.8}

\section{Ampicillune castis}

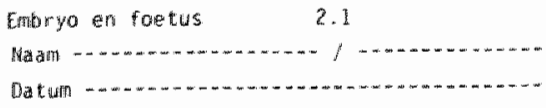

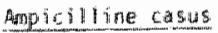

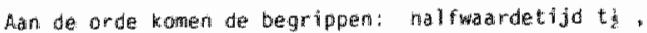

verdel ingsuro tume

klaring.

Foumble vor met verolingswalume is:

$$
0 \text { il }
$$

$$
\text { Wd }=0.0
$$

forthulle woor de klowing is:

$$
\text { karing }=\operatorname{Vt} \frac{0.693}{\mathrm{C}}
$$

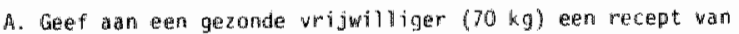

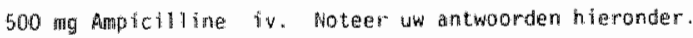

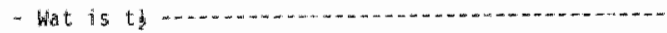

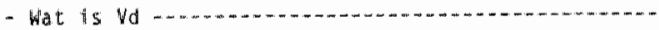

- Wat is ofe klarilig

D. Geef a an eem neomat $(4.5 \mathrm{~kg})$ een recept vam

... mg ampicilline liv. (Bepaa? dat ze\#f)

- Wat is th

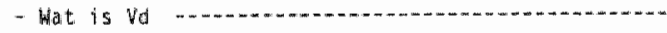

- Wat is de klaring

C. Geef a an een tachtigjarige persoon eem recept van

" i. Mg Artipicilline riv.

- Wat is t

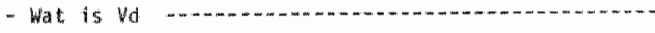

- We is de kiaring

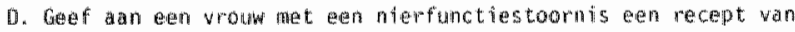

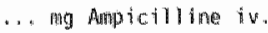

- What is

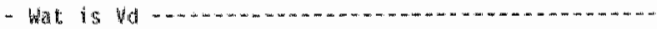

- Wot is de karting

Wak wan alle plasmakurwen een copie met het copieeraparat.

H. Thijssen en R. Hin 
CA. SWIS

blok 2.1

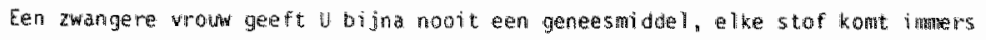
ook in de bloedbam van de foecus.

Toch kont het voor dat er iets gegeven moet worden. On een idee ontrent da

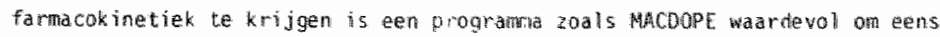

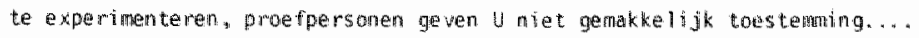

1. Doorloop eens het programa HACDOPE warn het begin tot het eind. Plane 1 ijh het witkiezen van een patient, hat uhtschrijuen van ean recept an het bestureren van de plasma concentraties.

bit is in de handeiding angegewen op paging $3 t / m$ de grafiek op pagina al,

Wat is de halfwardetiju van aspiritue? Mak eer schatcing:

Wat is de halfwardetijd van de gevornde tabolitet ?

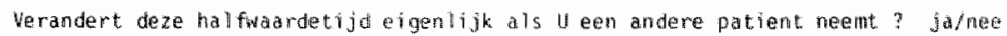
Contraleer dit eens net: MACOOPE :

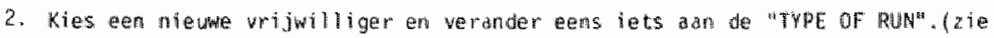
pagina 5. laats te 20 regelsy kles ean tabelworm ipv. eem grafiek.

Nerem voor de "LENGTH OF RUN" 6 wur" kies voor "MLMERICAL DISPHAY" en zorg dat de tabel iedere 60 MLifuTES een warde vertaont.

Als 1 het programina op deze wijze doorloapt kunt U de plasma concentraties op semi logaritmisch papier witzetten en veel nawkeuriger de hal fwardetijo bepalen Doet. U dit eens met penticilline. Wat is de mienwe warde?

Neen het wol gende recept: PENICILLIN | G IS STAT

(op pagina 7 ziet b hoe een recept geschreven dient te warden)

3. Heeft 1 nog tijd over, probeer dan exens wit te zoeken en te controleren ane MAC-

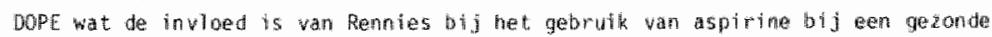

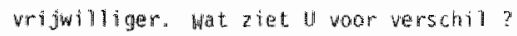

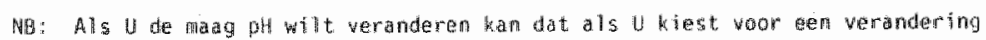

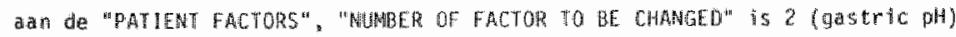
Hierna kunt $u$ dam weer thet recept untschrijven voor een aspirtine.

4. Bekijk ton ook eens wat het verschil is tussen een gezonda proefpersoon en een

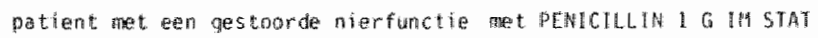

H. Thijusenten R. Min 
Append 1\% 8.1

begtanden van het programma

Bestanden, databanken of files met teksten of nummerieke data van het anamneseprogramma .

\begin{tabular}{|c|c|c|c|c|}
\hline & $\begin{array}{l}\text { bestand } \\
\text { flle } \\
\text { naam }\end{array}$ & $\begin{array}{l}\text { tekst } \\
\text { of } \\
\text { geta } 1\end{array}$ & $\begin{array}{l}\text { max.aantal } \\
\text { karakters } \\
\text { per record }\end{array}$ & grootte \\
\hline 1. & $\begin{array}{l}\text { vragenbestand: } \\
\text { MAVRA }\end{array}$ & tekst (ascii) & 288 & 334 records \\
\hline 2. & $\begin{array}{l}\text { an twoordenbest and: } \\
\text { MAYAA }\end{array}$ & tekst (ascii) & 288 & onbeperkt \\
\hline 3. & $\begin{array}{l}\text { persoonllike gege- } \\
\text { vens pat iênten- } \\
\text { bestand: } \\
\text { MPGEV }\end{array}$ & tekst (asciii) & 288 & $\begin{array}{l}20 \text { records/ } \\
\text { patient }\end{array}$ \\
\hline 4. & $\begin{array}{l}\text { vraag en vraag- } \\
\text { nummerbestand: } \\
\text { MSTUD }\end{array}$ & tekst (ascii) & 8.0 & 391 records \\
\hline 5. & $\begin{array}{l}\text { trefwoordenbe- } \\
\text { stand: } \\
\text { TREFW }\end{array}$ & tekst (ascii) & 80 & anbeperkt \\
\hline 6. & $\begin{array}{l}\text { data m.b.t. hoofd- } \\
\text { klachtvraag of } \\
\text { detalluraag: } \\
\text { MBLKK }\end{array}$ & getallen (ascili) & 24 & 143 records \\
\hline 7. & $\begin{array}{l}\text { patiënten- } \\
\text { bestand: } \\
\text { MPATAV }\end{array}$ & integer (16bit) & n.v.t. & $\begin{array}{l}600 \text { integers/ } \\
\text { patient }\end{array}$ \\
\hline 8. & $\begin{array}{l}\text { progranma- } \\
\text { teksten en } \\
\text { multiple choice } \\
\text { vragenbes tand: } \\
\text { MCOMV }\end{array}$ & tekst (ascil) & 80 & onbeperkt \\
\hline 9. & $\begin{array}{l}\text { bestand } t \cdot b . v . \text { sa- } \\
\text { mentellen van } \\
\text { vraag en antwoord- } \\
\text { lijst: } \\
\text { MONVR }\end{array}$ & $\operatorname{geta1} \operatorname{len}(\operatorname{asc} 1)$ & $n * v \cdot t$. & 334 records \\
\hline
\end{tabular}


Appendix 8.2

Vraagindeling bij het programa

Hoofdklachtvragen en detailvragen per tractus bif de anamnese (MAVRA).

\begin{tabular}{|c|c|c|c|}
\hline \multicolumn{2}{|l|}{ (In vragenbestand) } & \multicolumn{2}{|c|}{ (Niet in vragenbestand) } \\
\hline Hoofdklachtvragen & detailvragen, type 5 & \multicolumn{2}{|c|}{ detailvragen type $1,2,3,4$} \\
\hline 143 & 184 & \multicolumn{2}{|c|}{223} \\
\hline \multicolumn{2}{|c|}{ (gereserveerd : 50 vragen) } & \multicolumn{2}{|c|}{ totaal 600 vragen } \\
\hline \multicolumn{2}{|l|}{ Tractus/hoofdstuk } & \\
\hline \multicolumn{2}{|c|}{ tractusnummer: vraagnummer: } & \multicolumn{2}{|l|}{ vraagnummer: } \\
\hline \multicolumn{2}{|c|}{$\begin{array}{l}\text { 1. Algemene } \mathrm{klachten} \\
\qquad 8 \mathrm{t} / \mathrm{m} 30 \quad 23 \text { vragen }\end{array}$} & $362 \mathrm{t} / \mathrm{m} 378$ & 17 vragen \\
\hline \multicolumn{2}{|c|}{$\begin{array}{l}\text { 2. Tractus circulatorius } \\
31 \mathrm{t} / \mathrm{m} 93 \quad 63 \text { vragen }\end{array}$} & $380 \mathrm{t} / \mathrm{m} \quad 404$ & 26 vragen \\
\hline 3. Tractus respiratorius & $\begin{array}{l}\text { ins } \\
107 \quad 14 \text { vragen }\end{array}$ & \multicolumn{2}{|c|}{$405 \mathrm{t} / \mathrm{m} 412 \quad 8$ vragen } \\
\hline \multicolumn{2}{|c|}{$\begin{array}{l}\text { 4. Tractus digestivus } \\
\qquad 108 \mathrm{t} / \mathrm{m} \quad 168 \quad 61 \text { vragen }\end{array}$} & $413 t / m 463$ & 51 vragen \\
\hline \multicolumn{2}{|c|}{$\begin{array}{l}\text { 5. Tractus urogenitalis } \\
\qquad 169 \mathrm{t} / \mathrm{m} 208 \text { vragen }\end{array}$} & $464 \mathrm{t} / \mathrm{m} 482$ & 19 vragen \\
\hline \multicolumn{2}{|c|}{$\begin{array}{l}\text { 6. Tractus locomotorius } \\
209 \mathrm{t} / \mathrm{m} 234.46 \text { vragen }\end{array}$} & $483 \mathrm{t} / \mathrm{m} 512$ & 30 vragen \\
\hline \multicolumn{2}{|c|}{$\begin{array}{l}\text { 7. Tractus haemopaeticus } \\
235 \mathrm{t} / \mathrm{m} 248 \quad 14 \text { vragen }\end{array}$} & $513 \mathrm{t} / \mathrm{m} 523$ & 11 vragen \\
\hline \multicolumn{2}{|c|}{$\begin{array}{l}\text { 8. Tractus endocrinologicus } \\
249 \mathrm{t} / \mathrm{m} 260 \quad 12 \text { vragen }\end{array}$} & $524 t / m 535$ & 12 wragen \\
\hline \multicolumn{2}{|c|}{$\begin{array}{l}\text { 9. Centraal zenuwstelsel } \\
261 \mathrm{t} / \mathrm{m} 30848 \text { vragen }\end{array}$} & \multirow{3}{*}{$\begin{array}{l}536 \div / \mathrm{m} 581 \\
582 \div / \mathrm{m} 58.4\end{array}$} & 46 vragen \\
\hline $\begin{array}{r}\text { 10. Huidafwigking } \\
309\end{array}$ & 32315 vragen & & 3 vragen \\
\hline \multicolumn{2}{|c|}{$\begin{array}{l}\text { 11. Verdere gegevens } \\
\qquad \begin{array}{l}324 \mathrm{t} / \mathrm{m} 334 \quad 11 \mathrm{wragen} \\
1006 \mathrm{t} / \mathrm{m} 1014 \text { (p.m.) }\end{array}\end{array}$} & & $(p+m)$ \\
\hline \multicolumn{2}{|c|}{$\begin{array}{cc}\text { total } & 327 \text { vragen } \\
\text { (gereserveerd 1 t/m 7, } 335 \mathrm{t} / \mathrm{m} 361 \\
=3.4 \text { vragen) }\end{array}$} & \multicolumn{2}{|c|}{$\begin{array}{l}\text { totaal } 223 \text { wragen } \\
(585 \mathrm{t} / \mathrm{m} 600 \\
=16 \text { vragen })\end{array}$} \\
\hline
\end{tabular}


Append 1. 8.3

\section{Patientenbestaridindeling}

Pat ëntenbestand: $A\left(P_{j}, w_{j}\right)$ en $B\left(p_{j}, v_{1}\right)$

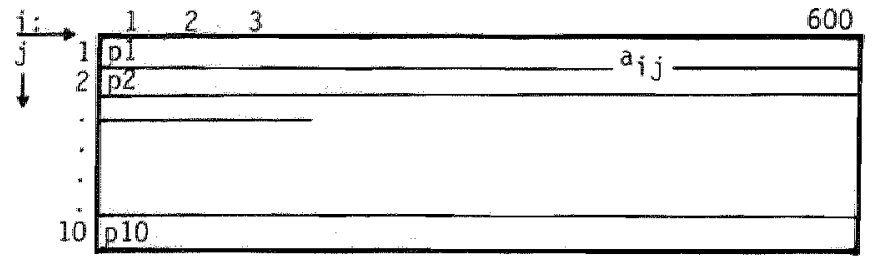

VOORBEELD:

a $31,7=75$

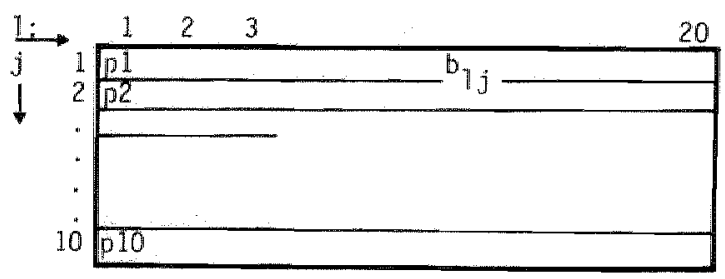

VOORBEELD:

b4, 4 =gehuwd, twee kinderen.

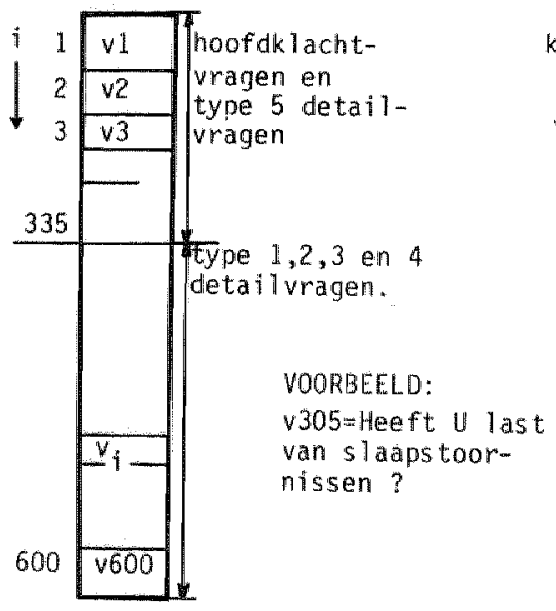

vragenbestand.

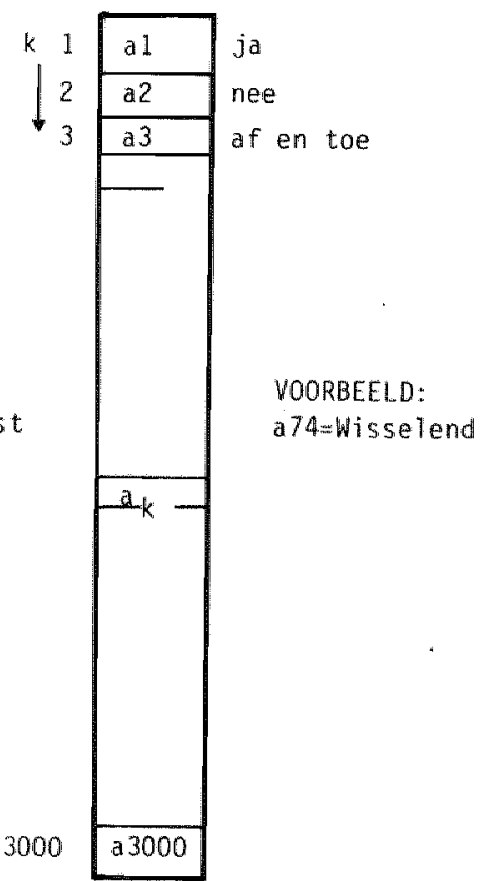

am twoordenbes tand. 
Appendix 9.1

Opbouw wan het model

Hec model dat aan het computersimulatieprograma ENzMM ten grondslag $1 \mathrm{igt}$ is een uitgebreider model dan zoals dat in hoofdstuk 9 beschreven wordt. Het bevat nast de enzymreactie die in dat hoofdstuk beschreven wordt ook een inhibitar (reactleremer). Hiermee kan het effect van een competieve en non-competieve intibitar reactie worden gesimuleerd.

Er worden 3 complexen gevornd (ES, EI en EIS) maar indien in dit model van een inhibitor concentratie van nul wordt uitgegaan is thet de basis enzymreactie gewotden zoals deze in het vorafgaande is beschreven.

Het complete model ziet er in de FORTRAN notatiewijze als volgt uit:

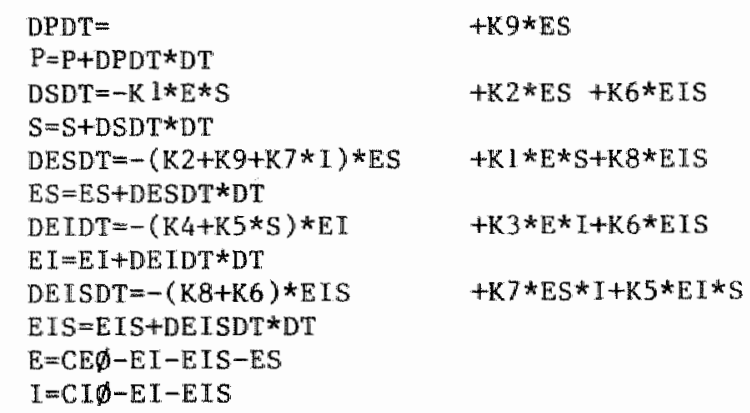


Indfatle van de kosten van computersimulatie

\section{Hardware software en courseware}

Als uitgegaan wordt van 3 verschillende conflguraties waarop de hier besproken computersimulatieprogramia's kunnen worden gebruikt zaals:

a. MLNC versie

1. MINC $11 \mathrm{BZ}(11 / 03)$ minicomputer incl. VTlos-terminal

2. Tektronix terminal

3. Tektronix hardcopy unit

4. Operating system (RTII)

b. VAX verste

1. VAX 14780 aanslulting inel. VT100-terminal

2. Tektronix terminal

3. Tektronlx hardcopy unte

c. VAX versie met GIGI termina ${ }^{3}$ )

1. VAX 11/780 a ansluting incl. WTloo-terminal.

2. GIGI terminal

3. hardcopy unit

dan zal afhankelijk van de uitvoering ${ }^{1}$ die gekozen wordt de kosten bif het gebrulk wan de hier besproken programma's ${ }^{2)}$ kunnen variëren van $f 5,-$ tot $f 25$,- per uur per 2 studenten.

\section{Begele L Ing}

Behalve de hard-en software kosten vergt het systeem een zekere hoeveelheid personeelskosten. Het is onmogelljk berekeningen aan te geven ondat deze kosten sterk afhankelijk zullen zijn van het onderwijssysteen warbinnen de programma"s worden gebruikt. Aan de RL is het beheer van het gehele systeem ca. $50 \%$ van de werkzamheden van éen technisch wetenschappelijk programeur gemoeld, terwijl de vakdocent begelelding ca. 15 minuten per sessle van 2 uur per 2 studenten kost.

1) De diverse mogelijkheden daarbij zija: een Tektronix cerminal of GIGI systerm; met of zonder hardcopy mogelijkheden; huur of aanschat wan een computersysteem.

2) MACDOPE en ANAMNESE kunnen op een alfanumerieke beeldschermterminal worden gebruikt. Bif AORTA, MACDOPEX etc. dient een extra gratisch medium te worden gebruikt.

3) Naast deze 3 computerconfiguraties zijn vele andere configuraties denkbaar met 64 kbyte CPU en FORTRAN IV. 
In deze woordenlijst zijn begrippen opgenomen die in dit proefschrift worden gebruikt. De verklaringen van de begrippen zijn deels gebaseerd op een Voc-rapport (Redactle: Gastkemper, Van Hees en v.d. Mast) wit 1979. waablij gebrulk gemaak is wan de Nederlandse norm NEM 3386 en verder gebaseerd is op de betekenls welke het begrip woor wat betreft het computersimulatte project heeft gekregen (andere bronnen: BEA-1ifst en IBM verklarend woordenboek).

Achtergrondgeheugen:

Adressererbare cursor:

Afdrukeenheid:

Alfanumerleke karakters:

Auteurstian:

Beeldgeheugen:

Beeldscherm:

Beeldschermformulter:

Beeldschermpagina:

Beeldschermterminal:

CAI: computergeheugen waarin informatie wordt opgeslagen, die langere tijd bewaard moet blijuen (floppy disk; magneetband etc.).

beweegbare punt (vlek) op een beeldscherm warvan de positie in een programma opgegeven wordt met twee coördinatoren en die de plats aangeeft wat het eerstwolgende teken zal verschijnen.

zie hard copy unit.

de verzameling karakters, die bestate uit letcers en cijfers; soms ook tekens.

taal warin de docent courseware schrijft.

geheugen in een beeldschermterminal; slechts alleen voor dat beeld dat op een bepaald moment op het beeldscherm wordt weergegeven.

een uitvoerorgaan warop gegevens (niet permanent) zichtbaar worden gegeven; vgl. een televisiescherm.

een beeldschermpagina die kan worden ingevuld $\mathrm{m} . \mathrm{b} . \mathrm{v}$. cursorsturingsprogrammatuur.

een hoeveelheid tekst op het beeldscherm die vergelljkbaar is met (een deel van) een pagina op papier.

terminal ultgerust met een toetsenbord voor de invoer van gegevens en een beeldscherm voor de uitvoer (weergave).

Computer Assisted Instruction; gebruik van de computer met daaran aangesloten randapparatuur als zelfstandig onderwifsmedium. Kenmerkend is de wissellwerking (interaktie) tussen dit medium en de student, warin de computer problemen of leerstof presenteert, vragen stelt of beantwoordt, hulp geeft, gedifferentieerd reageert op antwoorden van de student, berekeningen uitvoert, etc.

CAI-computers imulatieprograma: computers imulat leprograma gebaseerd op 
CAI-programma:

CAI-systeem;

CMI:

Compiler:

Computersimulatie:

Computersimulat ieprogramma:

Constante:

Courseware:

CPU:

Cursor:

dedicated:

Device:

Disk:

Dynamisch model:

Editor:

File: computerprogramma voor lle vormen van onderwifs en dat is gebaseerd op CAItechnieken.

stelsel van apparatur en programmatuur watmee CAI kan worden uitgevoerd.

Computer Managed Instruction: gebruik van de computer ter ondersteuning van het onderwifs, voor taken als het samenstellen en verwerken wan studietoetsen, het geven van verwijzingen nar lesmateriaal butten de computer en studie-adviezen en het verzamelen van gegevens $t . b . v$. de evaluatie.

vertaalprogramma (b.v. FORTRAN $\rightarrow$ machinetaal)

nabootsen wan de werkelijkheid d.m.v. een computerprogramu dat gebaseerd kan zijn op een algemeen model (b. . interview met de patiënt) of een wiskundig model (stelsel vergelijkingen).

computerprogranma gebaseerd op computersimulatie (hier over het algemeen een CAI-computers imulatieprogramma).

een grootheid in een wiskundig model die constant blijft in de tijd.

voor computerverwerking geprogrammeerd cursusmaterlaal.

centrale verwerkingseenheid (dè computer)

punt (vlek) op een beeldscherm, die de plaats aangeeft war het eerstwolgende teken zal verschijnen (zie ook adresseerbare cursor).

toegewijd. Computers worden dedicated genoend indlen zij voor slechts één toepassing gebrutkt (kunnen) worden, bljwoorbeeld voor CAL.

Input en/of output medtum (b. v . terminal, toetsenbord, disk, etc. )..

Schijfgeheugen.

een model warin tijdsathankelijke processen voorkomen.

tekstverwerkend programma, dat gebrufkt wordt on computerprogramma"s en tekstfiles mee op te maken. Het bledt mogelijkheden om verbeteringen aan te brengen, regels tussen te voegen of te verwijderen, bepaalde cermen op te zoeker, etc.

gegevensverzameling bestend voor een of meer bepalde toepassingen; bestand. 
toppy disk:

Frame:

Fystsche modellen:

Geheugen:

Geheugenscherm:"

Geprogrammerde Instructie:

Graftsche terminal:

Hard copy untt:

Hogere programeertaali:

Intercupte:

Interventie:

I. 10 :

Leerstation:

Mode1: klein schijfgeheugen van buigzaam maceriali zie ook disk.

zle beeldschermpagina.

een concrete (fysische) afbeelding van de werkelijkheld.

hier: intern of extern geheugen waar karakters in zijn opgeslagen.

beeldscherm warbij het beeldgeheugen zich "op" de glasplaat bevindt. Het oplossend vermogen is groot; de weergave is scherp en fijn gedetalleerd. Plaatsing van letters en symbolen is in princlpe selectief, het uitwissen niet.

onderwijstechniek, waarbij de leerling zelfstandfg en in eigen tempo een lesprogramma kan doorwerken. Het programma omvat de leerstof die is opgesplitst in zeer kleine stapjes (frames), bestaande uit een uiteenzetting en een direct daarop aansluitende vraag.

terminal waarop, naast alfanumerileke en bijzondere tekens, Iijnen van een willekeurige lengte en richting vertiond kunnen worden.

afdruk eenheid; een apparaat dat een afdruk op papier kan maken van het op de terminal vertoonde.

programmeertal die zich kenmerkt door het gebruik van mnemonische (merinneringssteunende) symbolen, macro-instructhes warin meerdere elementaire machineinstructies zijn samengevoegd en een syntax warin door de programmeur symbolenrijen kunnen worden geformeerd tot $\mathrm{com}^{-}$ plexe instructies. Programmeertalen worden hoger genoend naarmate de symtax conplexer is en ze minder athankelijk wan gastmachines gedefinieerd zijn. In de prakt $1 \mathrm{Jk}$ hebben computersystemen valk hun elgen dialecten.

Onderbreking (hier m,n. van de simulatie). hiler: een constante uit een wiskundige vergelijking die kan worden gebruikt on verstorlingen in het model te bewerkstelligen.

In- en uitwoer bewerking

Algemene term om een systeem mee aan te duiden waraan geleerd wordt.

afbeelding van de werkelijkheid. 
Modelgrootheid:

Modem:

Operating system:

Probleem georiënteerd onderwijs:

Programeertaal:

Responstijd:

Scroll (ing):

Simulatietaal:

\section{Simuleren:}

Startwaarde:

Statisch mode1:

Storage beeldscherm:

Systeem:

Systeemsof ware:

Tekstverwerkend programa*

Terminal:

Variabelen: constante en variabele grootheden in een wiskundig model.

Modulator/Demodulator; een toestel dat een digitaal signaal van de terminal of van de computer omzet in een analoog signaal (d.m.v. modulatie) en vice wersa, benodigd bij lijnverbindingen over langere afstand.

bedrijfssysteem voor computer.

vertaling van "Problem based learning"; een betere term voor probleem georienteerd onderwijs is overlgens probleem gestuurd onderwijs, ondat er bij het leren uitgegaan wordt van problemen.

Kunstmatige taal, speciaal ontworpen om computerprograma"s in te formuleren.

de tijd die verloopt tussen het verzenden van een boodschap vanaf de terminal en de ontwangst van de reactie wan let computersysteem.

werkwijze warbij het op de onderste regel invoeren van gegevens alle bovenstaande regels één doet opschuiven.

programmertal speciaal voor het oplossen van stelsel. (differential) of integraal. vergelijkingen.

nabootsen van de werkelijkheid.

warde die een afhankelijke of onafhankelijke of constante modelgrootheid heef $t$ op het moment $t=0$.

een model dat geen functie is van de tijd. zle geheugenscherm.

samenhangend geheel van thelen; hier in het bljzonder een stelsel van apparatur en/of programatur warmeden gewenste functie kan worden uitgevoerd, b.w w een CAI-systeem.

software die ervoor zorgt dat de computer (het computersysteem) bruikbaar is op het door het systeem gedefinieerde niveau b.v. operating system, compliers.

zie editor.

eindstation; in- en uitvoerorgaan voor conversationele gegevensverwerking in directe verbinding cussen gebruikex en computer.

modelgrootheid die een functie is van de tijd. 
Werkgeheugen:

Wikund $1 \mathrm{~g}$ model: het fysieke computergeheugen wastin gegevens $t i j d e l i j k$ worden opgeslagen voor onmiddellijk gebruik in een programa (belangrijk onderdeel van CPU).

een model dat kan worden wastgelegd in wiskundige relaties.

Bronnen, o.a.:

1. VoC rapport (Redactle Gastkemper, van Hees, v.d. Mast, 1979).

2. Beeldschermen, Ergonomische Aanbevelingen/ BEA 1ijst, Uitgave van Nederlandse Vereniging voor Ergonomie, Amsterdam (1979).

3. IBM verklarend woordenboek, computertechnologie. IBM Nederland B.V. $(197-)$. 


\section{Dankwoord}

Dit proefschrift zou niet tot stand $z i j n$ gekomen zonder de hulp var al degenen die bij het project computersimulatie betrokken ajn geweest. On te beginnen wil ik een bijzonder woord van dank richten aan mifn promotor prof.dr. H.A.J. Struyker Boudier. Harry, jouw idee on modelvorming en simulatie te gaan integreren in het medisch onderwijs bleek een uitstekend idee en was een goede basis voor samerwerking binnen de capaciteitsgraep farmacologie, maar ook daarbuiten. De resultaten van onze samenwerking hebben heel cancreet lets opgeleverd voor het onderwijs aan de RL. Verder dank voor de vele uren die je aan dit proefschrift hebt besteed.

Mijn co-promotor prof.dr. W.H.F.W. Wijnen dank ik voor de belangstelling die hij toonde voor mijn werk, de gesprekken hierover en het kritisch lezen van het manuscript.

Mijn referenten dr. F.I.M. Bonke, dr. A. Dirkzwager en dr. J.M. van Rossum dank ik voor de serieuze, kritische aanpak bij, het lezen wan het manuscript Voor de hulp die ik bij de uttvoering van het RL-computersinulatiesysteem heb gehad wil ik met name Hub van Kan bedanken voor het werk dat hij hiervoor heeft verzet. Hub, veel dank, ook voor je bijdrage aan de tot standkoming wan dit boek, m.n. bij de afwerking van de figuren en het vele fotowerk.

A1 mijn collega's wil ik danken voor hun directe en indirecte hulp en hun -zoals dat in ans RL-jargon heet- "inhoudsdeskundighedd" bli juijn "problemen":

Henk Thijssen voor zijn inbreng bij alles wat FARMA en MACDOPE te maken heeft en ajjn kritisch commentaar hieromtrent bij het manuscript; Jos Smits voor zijn hulp bijenkele problemen bij de casulstiek van het programma CARDIO, Marleen van Baak voor haar bijdrage aan de casuistlek van Fluids en Jos Klelnjans voor de vele discussles over het werk die we op onze kamer voerden.

Verder dank ik Gonnle Jongmans-Liedekerke die als studentassistente haar bijdrage leverde aan de casuistiek van ANAMNSE en FUUIDS en Roland Böhm die als studentassistent zijn bijdrage leverde an de casuistiek yoor FLUIDS en CARDIO.

George Willems dank ik voor zijn kitische opmerkingen bij hoofdstuk 9; Tjaart Imbos voor zijn bijdrage aan het verzamelen en verwerken van enkele toetsgegevens en Els Boshuizen yoor hat hulp en opmerkingen bij hoofdstuk 10 . 
Guus van Rooy w11 ik bedanken voor zijn hulp bij enkele ingewikkelde figuren en zijn werk bij de opmaak van de omslag.

Tijdens de moellijke perlode van het tot stand komen van het manuscript tot en met het defintlief uittypen van de tekst heb $1 k$ een onmisbare steun ondervonden en hulp gehad van Barbara Geers, Mia Hogenboon en Nelly Baltussen. Dank voor jullie geduld bij het uitwerken van dit proefschrift.

De ultgave van dit proefschrift is mede mogelijk gemaakt door Digital Equipment B.V. te Utrecht en Roussel Laboratoria B.V. te Hoevelaken. 
E.B.M. Min werd geboren in 1946 in Bergen (NH). In 1968 behaalde hij eindexamen van de HTS re Haarlem (Electrotechniek). HIJ studeerde a am de Technische Hogeschool te Delft, alwar hij in 1975 aan de afdeling Medische Electrotechniek afstudeerde op het praject "Modelvorming van de electrische geleidingsmechanismen in de maag en het hart". Dit gebeurde in samemwerking met de Erasmus Universiteit, afdeling Medische Techniek.

Hierma was hij twee en een half jaur werkzam bij de afdeling Nucleatre Geneeskunde van de Medische Faculteit wan de Rijksuniversiteit utrecht. Hier starte hij met een project "Computersimulatie voor het oefenen in het opmemen vat een anamese bi gesimuleerde patiënten" $t$.b.v. het medisch onderwijs.

Vanaf oktober 1978 werkte hij als wetenschappelijk medewerker bij de capaciteitsgroep farmacologie (voorzitter H.A.J. Struyker Boudier) van de Rijksuniversiteit Limburg. Hier is hij vier jaar werkzaam geweest aan het project "Computersimulatie als basisleermiddel voor probleem georiënteerd medisch onderwijs".

Vanaf I november 1982 is hij werkzaam als wetenschappelijk medewerker bij de afdeling Toegepaste Onderwijskunde van de Technische Hogeschool Twente.

\section{Publicaties en rapporten waraan werd medegewerkt}

1. Kingma, Y.J. and F.B.M. Min:

Mathematical models of electrical control activity in the smoot muscle of the gastro-intest inal tract. Procedings of the libth Dutch lederation Meet ing

2. Min, F.B.M.:

Anamese Training; een computersimulateprograma. Institume var Nuc leaire Geneeskunde, Rijksuniversitelt Utrecht, interne uitgave (1978).

3. Min, F.B.M. en K.H. Ëphrain: Computer assisted instruction voor het leren overzien van de anamese. Proceedings Medisch Informatica congres "79 (red. J.L. Willems), Acco Leuver; Antwerpen $117-122$ (1979).

4. Struyker Boudier, H.A.J. en F.B.M. Min:

Computer similation of the cardiovascular system. In: Proceedingz of the loth Conference of the International Stmulation and Gaming Association (red. K. Bruin), Leewwarden. Vol. I, 321-328 (1979).

5. Min, F.B.M. en H.A.A. Struyker Bowdier: Computer simulation in problem oriented medical learning. In: Proceedings International Stmulation and Gaming Association Conference (red. K. Bruln), Leewwarden. Vol. II, 186-196 (1979). 
6. Struyker Boudier, H.A.J., R. Evenwell, F.B.M.Min, J.F.M. Snits: Antihypertensive geneesmiddelen: interacties met de regulat it van de bloeddruk. In: "Regulatie van de bloeddruk" (red. H.A.J. Struyker Boudier). Wetenschappelijke Uitgeverij Bunge, Utrecht, $90-103$ (1979).

7. Min, E.B.M. en H.A.J. Scruyker Boudier:

Computersimulatie met modellen uit de fysiologie en famacologie voor het medisch onderwijs. Proceedings Medisch Informatica Congres 180 (Ed. P. v.d. Wulp) Rotterdam, 197-203 (1980).

B. Struyker Boudier, H.A.J. en F.B.M. Min:

Wiskundige modellen en medische wetenschappen. In: Teleac cursus Wiskundige Modellen, Cursusboek (Coörd. J. v.d. Boogert), 187-203, Utrecht $(1981)$.

9. Min, F.B.M., H.M. van Kan, H.A.J. Struyker Boudier:

Computergesturd onderwjs in de geneeskunde: Het programa:

CARDIO, een computersimulatie gebaseerd op een model van de bloeddrukregulatie. In: voc-publicatiereeksi 80/04 (Red. J. Moonen). Vereniging Onderwijs en Computer, Utrecht, 52-60 (1981).

10. Struyker Boudier, H.A.J. en F.B.M. Min:

Wiskundige modellen in medisch onderzoek en onderwijs.

Paramedica $1,17-21(1981)$.

11. Min, F.B.M., H.M. van Kan and H.A.J. Struyker Boudier:

Computer simulation programs in problem orlented medical

learning at the University of Limburg.

1) Proceedings symposium in Computer Assisted Learning ' 81

(ed. P.R. Smth), Leeds 153-158 (1982).

2) Comp. \& Educ. 6, 153 (1982).

12. Struyker Boudier, H. A.J., F.B.M. Min, H.M. van Kan, H.H.W. Thijssen: Computersimulatie in het medisch onderwijs aan de Rijksuniversiteit Limburg. In: Computergestuurd (hoger) onderwijs. (red. J. Moonen en F. gastkemper) (in druk). 